\title{
Ensino de ciências e matemática I
}

temas sobre a formação de professores

Roberto Nardi

(org.)

NARDI, R. org. Ensino de ciências e matemática, I: temas sobre a formação de professores [online]. São Paulo: Editora UNESP; São Paulo: Cultura Acadêmica, 2009. 258 p. ISBN 978-85-7983-004-4. Available from SciELO Books $\langle$ http://books.scielo.org $>$.

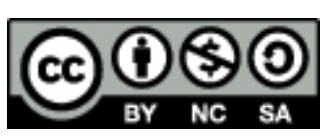

All the contents of this work, except where otherwise noted, is licensed under a Creative Commons Attribution-Non Commercial-ShareAlike 3.0 Unported.

Todo o conteúdo deste trabalho, exceto quando houver ressalva, é publicado sob a licença Creative Commons Atribuição Uso Não Comercial - Partilha nos Mesmos Termos 3.0 Não adaptada.

Todo el contenido de esta obra, excepto donde se indique lo contrario, está bajo licencia de la licencia Creative Commons Reconocimento-NoComercial-CompartirIgual 3.0 Unported. 


\section{ENSINO DE CIÊNCIAS \\ E MATEMATICA I}

TEMAS SOBRE FORMAÇÃO

DE PROFESSORES

ROBERTO NARDI (ORG.) 


\section{Ensino de Ciências e Matemática I}



ROBERTO NARDI (ORG.)

\section{Ensino de Ciências e Matemática I TEMAS SOBRE FORMAÇÃO DE PROFESSORES}


(C) 2009 Editora UNESP

\section{Cultura Acadêmica}

Praça da Sé, 108

01001-900 - São Paulo - SP

Tel.: (0xx11) 3242-7171

Fax: (0xx11) 3242-7172

www.editoraunesp.com.br

feu@editora.unesp.br

CIP-Brasil. Catalogação na fonte

Sindicato Nacional dos Editores de Livros, RJ

E52

v. 1

Ensino de ciências e matemática, I: temas sobre a formação de professores / Roberto Nardi (org.). - São Paulo : Cultura Acadêmica, 2009.

ISBN 978-85-7983-004-4

1. Ciência - Estudo e ensino. 2. Matemática - Estudo e ensino. 3. Professores de ciêncis - Formação. 4. Ciência - Estudo e ensino - Filosofia. 4. Ciência - Aspectos sociais. I. Nardi, Roberto.

09-6056.

CDD: 507

CDU: $5(07)$

Este livro é publicado pelo Programa de Publicações Digitais da Pró-Reitoria de Pós-Graduação da Universidade Estadual Paulista "Júlio de Mesquita Filho" (UNESP)

Editora afiliada:

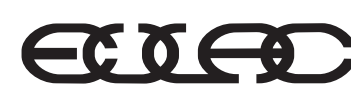

Asociación de Editoriales Universitarias de América Latina y el Caribe

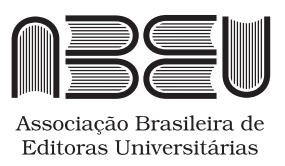




\section{SUMÁRIO}

\section{Apresentação 7}

1 Investigação temática na formação de professores de Física e no ensino de Física 11

2 As atividades de campo no ensino de Ciências: reflexões a partir das perspectivas de um grupo de professores 27

3 Formação inicial de professores de Química: formação específica e pedagógica 43

4 Ensino de Ciências e Educação Moral: implicações mútuas 59

5 Um estudo exploratório sobre o ensino de Astronomia na formação continuada de professores 75

6 Análise de práticas pedagógicas realizadas em atividades de formação continuada de professores: a aproximação da História e Filosofia da Ciência no ensino de Física 91

7 Inclusão no ensino de Física: materiais e metodologia adequados ao ensino de alunos com e sem deficiência visual 109

8 O ensino de Ciências e seus desafios para a inclusão: o papel do professor especialista 133

9 Dificuldades dos professores em introduzir a Física Moderna no Ensino Médio: a necessidade de superação da racionalidade técnica nos processos formativos 145

10 Os processos de elaboração e operacionalização de uma estrutura curricular na formação de professores de Física: as intenções legais, os discursos dos formadores e suas práticas docentes 161 
11 O ensino de Ciências nas séries iniciais: desenvolvimento de aprendizagens profissionais no âmbito da formação de professores 179

12 A formação de professores: uma revisão das últimas décadas em revistas brasileiras da área de Educação Matemática 193

13 Formação de professores de Ciências em exercício no Estado da Bahia 209

14 Ensino de Ciências Naturais e a formação de professores: potencialidades do ensino não formal da Astronomia 225

15 Ensino de Física, analogias e a dinâmica do contexto interativo discursivo em sala de aula 243 


\section{ApresentaÇÃo}

Roberto Nardi

O Programa de Pós-Graduação em Educação para a Ciência, sediado na Faculdade de Ciências da Unesp, iniciou suas atividades em 1997, sendo um dos primeiros a se credenciar junto à Coordenação de Aperfeiçoamento de Pessoal de Nível Superior (Capes), na área de ensino de Ciências e Matemática. As primeiras dissertações concluídas no Programa foram defendidas a partir de 1999, tendo sido até hoje homologadas um total de 187 dissertações de mestrado e 25 teses de doutorado. Desde o seu início, o Programa vem implementando parcerias nacionais e internacionais com grupos de pesquisa e instituições diversas e programas interinstitucionais financiados pela Capes, como o Programa Nacional de Cooperação Acadêmica (Procad) e os Programas de Doutorado Interinstitucional (Dinter) e, em nível internacional, com universidades da França, Portugal e Colômbia.

O núcleo de pesquisa do Programa concentra-se em estudos sobre a Ciência, a educação científica e nas relações entre o saber científico e seu ensino. Assim, incentiva a reflexão sobre os processos envolvidos na construção dos conhecimentos científicos e tecnológicos, além de contribuir para a produção de um corpo de conhecimentos filosóficos, científicos e pedagógicos destinados à formação de professores e outros profissionais da área.

Seis linhas de pesquisa integram o Programa de Pós-Graduação em Educação para a Ciência: 1) Filosofia, História e Sociologia da Ciência no ensino de Ciências; 2) Ensino de Ciências em espaços não formais e divulgação científica; 3) Fundamentos e modelos psicopedagógicos no ensino de Ciências e Matemática; 4) Informática em Educação em Ciências e Mate- 
mática; 5) Linguagem, discurso e ensino de Ciências; 6) Ciência, tecnologia, ambiente e desenvolvimento humano.

Este livro apresenta, no conjunto de seus capítulos, uma parte das recentes produções do Programa, já aprovadas em bancas examinadoras, tendo como pano de fundo a questão da formação de professores.

No primeiro capítulo, intitulado "Investigação temática na formação de professores de Física e no ensino de Física", os autores apresentam e discutem uma análise do processo e das estratégias de codificação e decodificação que adotam na investigação temática para a obtenção de redes conceituais prévias em Física. Diante dos dados obtidos, buscam a reconstrução racional da história da própria prática e constatam a relevância da investigação temática para inserção da problematização das implicações da relação Ciência, Tecnologia, Sociedade e Ambiente (CTSA).

No capítulo que segue, os autores de "As atividades de campo no ensino de Ciências: reflexões a partir das perspectivas de um grupo de professores" discutem sobre o papel das atividades de campo como estratégia no ensino das Ciências, mais especificamente na Educação Ambiental, em investigação que fizeram com um grupo de professores em uma atividade de campo promovida pelo Centro de Divulgação Científica e Cultural da Universidade de São Paulo (CDCG/USP).

"Formação inicial de professores de Química: formação específica e pedagógica" é o título do próximo capítulo, no qual os autores abordam a formação pedagógica e específica de licenciandos em Química com base em dados e reflexões referentes a um estudo realizado, por meio do qual foi possível identificar problemas em relação à formação inicial dos professores.

Embasados por teorias sociomorais, os autores de "Ensino de Ciências e Educação Moral: implicações mútuas" argumentam em prol das possibilidades de subsídios mútuos entre o ensino de Ciências e a Educação Moral. Defendem no texto que o ensino de Ciências crítico e desmistificado potencializa o desenvolvimento moral, assim como os princípios teóricos do desenvolvimento também são subsídios para o ensino de Ciências na perspectiva da desmistificação da visão de ciência e construção crítica do conhecimento.

Em "Um estudo exploratório sobre o ensino de Astronomia na formação continuada de professores", relata-se um estudo sobre a formação continuada de professores da Educação Básica, que visou o desenvolvimento profissional quanto à prática de ensino de conteúdos relacionados à Astronomia. 
No capítulo seguinte, intitulado "Análise de práticas pedagógicas realizadas em atividades de formação continuada de professores: a aproximação da História e Filosofia da Ciência no ensino de Física", os autores utilizam-se de um curso que realizam para analisar o desenvolvimento de atividades de formação continuada com docentes de Física, buscando-se aproximar a História e Filosofia da Ciência do ensino.

Ensino de Física para alunos com deficiência visual é o tema do artigo "Inclusão no ensino de Física: materiais e metodologia adequados ao ensino de alunos com e sem deficiência visual". Na abordagem, os autores apresentam artefatos tátil-visuais que facilitam o processo de ensino e atendem às necessidades de inclusão.

Em "O ensino de Ciências e seus desafios para a inclusão: o papel do professor especialista", o foco dos autores foi analisar a situação que se encontra o professor especialista em deficiência visual presente em uma escola estadual. Para tanto, utilizam referenciais teóricos relacionados à Educação Inclusiva e motivação.

"Dificuldades dos professores em introduzir a Física Moderna no ensino médio: a necessidade de superação da racionalidade técnica nos processos formativos" é o título do próximo capítulo. Os autores analisam nos discursos de professores de Física algumas marcas das respectivas formações e identificam influências da racionalidade técnica dificultando o intento dos professores.

O capítulo denominado "Os processos de elaboração e operacionalização de uma estrutura curricular na formação de professores de Física: as intenções legais, os discursos dos formadores e suas práticas" apresenta algumas reflexões dos autores acerca de uma pesquisa realizada entre 2002 e 2004 junto a docentes universitários com atuação como formadores de professores de Física.

O capítulo intitulado "O ensino de Ciências nas séries iniciais: desenvolvimento de aprendizagens profissionais no âmbito da formação de professores" consistiu expor e discutir um modelo de investigação que objetivou verificar se um conjunto planejado de interações entre os pesquisadores e uma professora das séries iniciais favoreceria a aprendizagem.

No capítulo "A formação de professores: uma revisão das últimas décadas em revistas brasileiras da área de matemática", os autores apresentam resultados de uma investigação que teve por objetivo a análise dos artigos 
relacionados ao campo de formação de professores em 32 anos de publicação da área de educação matemática em revistas brasileiras.

Em "Formação de professores de Ciências em exercício no Estado da Bahia", as autoras constroem um quadro que permite clarear a situação da formação de professores de Ciências em exercício na Bahia, entrelaçando histórias de 16 professores de Ciências com as ações governamentais relacionadas ao assunto.

Em "Ensino de Ciências Naturais e a formação de professores: potencialidades do ensino não formal da Astronomia", os autores defendem que os planetários, observatórios astronômicos e clubes de astrônomos amadores podem oferecer atividades a ser incluídas na listagem de estabelecimentos de educação não formal em astronomia, cujas potencialidades formativas são brevemente consideradas neste trabalho.

Encerrando o livro está o capítulo intitulado "Ensino de Física e a dinâmica do contexto interativo discursivo em sala de aula". Nesse capítulo apresentam-se resultados parciais de uma investigação que relaciona o estudo das analogias no Ensino de Física com a formação de professores e as questões de linguagem, especificamente quanto à elaboração, utilização/ exploração destas nos processos interativos discursivos em sala de aula. 


\title{
1 \\ INVESTIGAÇÃO TEMÁTICA NA FORMAÇÃO DE PROFESSORES DE FÍSICA E NO ENSINO DE FísICA
}

\author{
João Amadeus Pereira Alves ${ }^{1}$ \\ Washington Luiz Pacheco de Carvalho ${ }^{2}$ \\ Rejane Aurora Mion ${ }^{3}$
}

\section{Introdução}

Diante das mudanças atuais nos cursos de licenciatura em Física, o que incluiu estágio curricular supervisionado em ensino de Física, no qual se situa nossa atuação docente, nossas pesquisas e outros estudos, temos discutido e implementado novas estratégias e também lançado mão de novos recursos para a realização da investigação temática, baseada em Freire (1983).

A investigação temática é inaugurada pela relação estabelecida entre o aprendiz de professor e pesquisador e a realidade da escola na qual ele estagia. Se por um lado é isto que estabelecemos como o ponto de partida para que tal investigação ocorra, o mesmo não podemos dizer sobre o seu término, uma vez que enquanto houver diálogo haverá espaço para complementar o arcabouço de dados e informações pertinentes à atividade de formação docente.

Nossa intenção é a de inserir na investigação temática a problematização das implicações da relação Ciência, Tecnologia, Sociedade e Ambiente (CTSA). Defendemos que tal inserção é indispensável para que os alunos

1 Docente da Universidade Estadual Paulista Júlio de Mesquita Filho (Unesp), Faculdade de Ciência, campus de Bauru, e da Universidade Estadual de Ponta Grossa, Departamento de Métodos e Técnicas de Ensino (UEPG-Demet).

2 Professor-adjunto da Faculdade de Engenharia, campus de Ilha Solteira, e do Departamento de Física e Química da Universidade Estadual Paulista Júlio de Mesquita Filho (Unesp).

3 Docente da Universidade Estadual de Ponta Grossa, Departamento de Métodos e Técnicas de Ensino (UEPG/PPGE). 
da Educação Básica, dentre outras possibilidades, se aproximem de modo efetivo da complexa problemática energética do planeta e das causas do aquecimento global.

O trabalho que permitiu a escrita deste texto foi desenvolvido junto à formação inicial de professores de Física, tendo a investigação temática como fundamento teórico epistemológico e metodológico para o delineamento do estágio curricular supervisionado em ensino de Física. Em se tratando do que temos feito junto à formação inicial de professores de Física, a investigação temática, que só pode ser pensada para e como uma intervenção na realidade (Freire, 1983), é encarada como uma componente indispensável da função social do futuro professor, a ser desenvolvida durante a formação deste. A partir da investigação temática se permite conhecer o que os alunos pensam, como pensam e porque é desse ou daquele modo que pensam a respeito das temáticas de Física a serem ensinadas/aprendidas no Ensino Médio.

$\mathrm{Na}$ nossa realidade teórico-prática, pesquisada e analisada, a investigação temática constitui o germe da reconstrução curricular. É um iniciar-se na busca de identidade profissional e ética do professor, em que se entende, a partir dos escritos de Anselm Strauss, ser a reflexão sobre a ação igual à observação orientada da prática planejada e vivida, o que permite ao sujeito despir-se das suas máscaras à medida que constrói a sua prática (Strauss, 1999).

A questão de pesquisa que orienta a apresentação deste texto é: Como licenciandos-estagiários em Física podem ser instrumentados de modo a enfrentar o racionalismo técnico, por um lado, e a absolutização da prática, por outro, que estimulam visões ingênuas sobre Ciência, Tecnologia, Sociedade e Ambiente em detrimento de uma visão crítica?

O processo de elaboração, desenvolvimento e análise da investigação temática, tendo como pano de fundo a problemática energética, qual seja, a sua escassez por um lado e as novas fontes de energia por outro, e o aquecimento global, gera a necessidade de incluir essas discussões como conteúdo escolar. Especificamente, gera a necessidade de se incluir esses temas no currículo das disciplinas mais diretamente envolvidas e que compõem a educação científica e tecnológica, da subárea das Ciências da Natureza, Matemática e suas Tecnologias, especialmente da Física. Ao fazê-lo, agimos com intenção e colocamo-nos a serviço de um processo de conscientização (Freire, 1980). 


\section{Investigação temática e ensino de Física}

Para Freire (1983), a investigação temática só pode ocorrer na relação de diálogo entre os envolvidos na prática educacional mediados pelo mundo. A investigação temática situa-se na realidade a ser investigada, tendo a conhecer um objeto técnico que tem em comum com envolvidos o fato de estes estarem no mundo, dele fazerem parte e nele poderem fazer transformações. E isso é o que também diferencia o ser humano dos outros animais.

Aqui, analisamos e defendemos a prática educacional, o que fazer, o nosso trabalho e o processo ensino-aprendizagem da Física, que são dimensões da realidade educacional e social a ser investigada, pois "o que se pretende investigar, realmente, não são os homens como se fossem peças anatômicas, mas o seu pensamento-linguagem referido à realidade, os níveis de sua percepção desta realidade, a sua visão do mundo" (Freire, 1983, p.103).

A investigação temática é planejada em primeiro lugar para abrir o diálogo entre os envolvidos e investigar o seu pensar, para conhecermos o que pensam e porque pensam do modo que pensam a temática da Física como um problema a ser resolvido coletiva e colaborativamente, em primeiro lugar para que os aprendizes de professor e pesquisador em ensino de Física aprendam a fazer e compreendam que faz parte da função social de um professor elaborar o próprio plano de curso; em segundo lugar, fazer e proporcionar o mesmo processo aos demais envolvidos, seus alunos do Ensino Médio, para a definição da rede conceitual prévia e, consequentemente, do plano de curso da disciplina e da série em que vai trabalhar; em terceiro, para realizar uma investigação da realidade educacional e obter informações sobre esta e, com isso, realizar uma redefinição curricular mais abrangente e mais informada para o Ensino Médio e; em quarto lugar, poderíamos dizer que este é um processo de problematização de conceitos e práticas, uma prática educacional necessária na formação inicial e continuada de um professor e pesquisador em ensino de Física, pois provoca a interlocução entre a formação desse professor e o próprio ensino de Física.

Do ponto de vista teórico-prático e educacional, encontramos respaldo no texto Pedagogia do oprimido para inserir a problematização das implicações da relação CTSA no contexto da investigação temática, como uma apropriação do entendimento de ser humano e de mundo. E este só se concebe pela existência de seres humanos nele. 


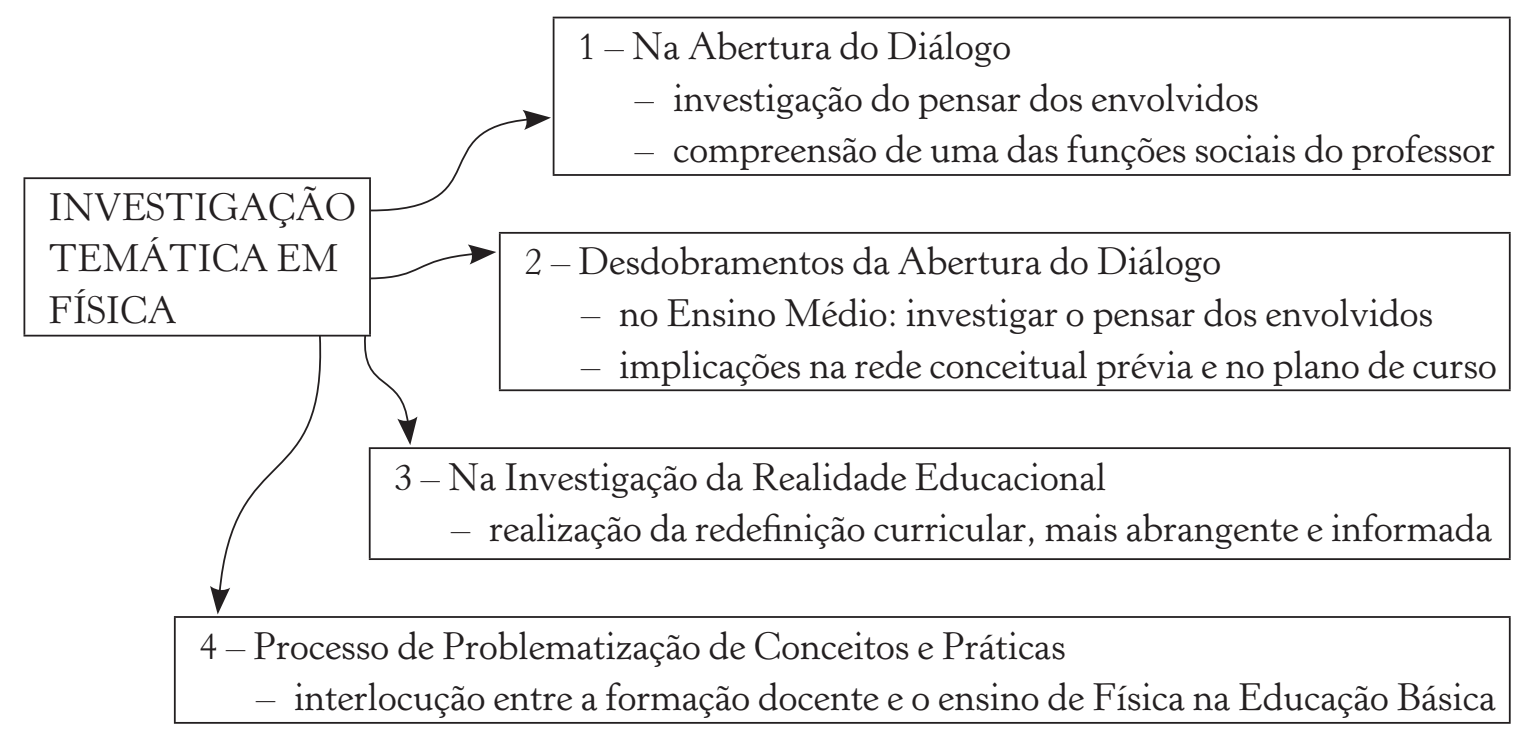

Figura 1 - Investigação temática na formação do professor e pesquisador em Ensino de Física.

Este é um esforço que cabe realizar não apenas na metodologia da investigação temática que advogamos, mas também na educação problematizadora que defendemos. O esforço de propor aos indivíduos dimensões significativas de sua realidade, cuja análise crítica lhes possibilite reconhecer a interação de suas partes (Freire, 1983, p.113).

Nas últimas três décadas, o campo científico tem ampliado os estudos, as discussões e os novos interesses sobre essa problemática sócio-ambiental, a ponto de muitos dos seus representantes darem novos direcionamentos a seus posicionamentos, tidos até então como conservadores. As mais recentes mudanças climáticas ocorridas no planeta Terra têm chamado a atenção dos cientistas, dos governantes e da sociedade civil organizada (Richardson; Blades, 2002; Pedretti et al., 2008). A temperatura média da superfície do planeta tem sido detectada como crescente, a partir das constatações e das divulgações feitas principalmente a partir de 2007 pelos pesquisadores que integram o Painel Intergovernamental sobre Mudanças Climáticas (IPCC).

Em grande escala, esses problemas geram incontáveis danos, dentre os quais se destacam: aumento do nível do mar; menor produção de alimentos (principalmente da fauna ictina); redução acelerada do número de espécies animais e vegetais; chuvas mais intensas e mudanças de sazonalidade de ocorrência em alguns lugares, em detrimento a outros; estiagens mais dura- 
douras em regiões mais áridas; maior incidência de doenças (a exemplo do câncer de pele motivado por maior radiação ultravioleta), segundo diferentes estudos apresentados pelo Instituto Nacional do Câncer (Inca); menor produção do isopreno ${ }^{4}$ nas regiões de vegetação tropical; menor retenção de água pelo solo e perda de sua capacidade de nutrir plantas, dentre muitos outros.

Questões dessa natureza precisam ser tratadas educacionalmente. Sobre isto, temos investido nossos esforços nas disciplinas de Estágio Curricular Supervisionado em Ensino de Física 1 e 2.

\section{A metodologia}

Realizado em um curso de formação inicial e continuada de professores de Física, no interior de um programa de investigação-ação educacional, o processo de elaboração, desenvolvimento e análise da investigação temática durou seis semanas letivas ${ }^{5}$, culminando com as redes conceituais prévias construídas. A coleta de dados empíricos foi realizada por meio de observação direta: por escrito, guiada por um roteiro (Mion, 2002) e por meio de gravações eletrônicas (áudio, vídeo e computador).

As estratégias utilizadas para a realização da investigação temática no Ensino Médio por parte dos licenciandos-estagiários foram articuladas intrinsecamente. Para a elaboração de cada uma delas, seguimos os quatro momentos da espiral de ciclos de origem lewiniana: planejamento, ação, observação e reflexão (Carr; Kemmis, 1988).

A análise dos dados da investigação temática se deu sobre a elaboração e desenvolvimento de seis estratégias, conforme a descrição a seguir.

4 O isopreno é um gás produzido tipicamente em floresta tropical que, ao ascender à atmosfera, contribui na cristalização das partículas d'água dispersas, tornando estas mais densas e facilitando a precipitação. Mas com o excesso de $\mathrm{CO}_{2}$ na atmosfera, este compete com o isopreno, e, assim, as partículas d'água não adquirem o tamanho necessário e a cristalização. Com isso, elas não vencem a tensão superficial atmosférica a ponto de precipitarem.

5 Totalizaram-se 36 horas/aula na disciplina de Estágio Curricular Supervisionado em Ensino de Física II, sendo que dessas, 18 ocorreram na Universidade, e as demais ocorreram em cada escola envolvida com o estágio. 
Tabela 1 - Estratégias realizadas durante a investigação temática.

\begin{tabular}{|c|c|}
\hline Semana & Síntese das estratégias realizadas durante a Investigação Temática \\
\hline 1 a & - Participação na Semana Pedagógica na Escola. \\
\hline $2^{\mathrm{a}}$ & $\begin{array}{l}\text { - Problematização da prática educacional com três vídeos (que não são de ficção) } \\
\text { sobre a problemática energética mundial e o aquecimento global. } \\
\text { - Construção de um texto sobre esses vídeos. }\end{array}$ \\
\hline 3 a & $\begin{array}{l}\text { - Problematização do conceito de ser humano e de produção de lixo a partir } \\
\text { da exibição do filme Ilha das Flores (que também não é uma ficção), de Jorge } \\
\text { Furtado (1989). } \\
\text { - Construção de um texto sobre esse filme assistido. }\end{array}$ \\
\hline $4^{\mathrm{a}}$ & $\begin{array}{l}\text { - Levantamento dos objetos, aparelhos, coisas e fenômenos que os alunos do } \\
\text { Ensino Médio utilizam e/ou conhecem e/ou relacionam com o tema de Física. } \\
\text { - Classificação sob categorias físicas dos objetos, aparelhos, coisas e fenômenos que } \\
\text { os alunos utilizam e/ou conhecem e/ou relacionam com o tema (GREF, 1998). }\end{array}$ \\
\hline 5 a & $\begin{array}{l}\text { - Atividade de investigação e análise do livro didático público. } \\
\text { - Problematização de questões envolvendo implicações da relação CTSA a partir } \\
\text { do Exame Nacional do Ensino Médio (Enem, 2007). }\end{array}$ \\
\hline $6^{\underline{a}}$ & $\begin{array}{l}\text { - Apresentação da rede conceitual, do plano de curso e do Sistema de Avaliação } \\
\text { aos alunos do Ensino Médio envolvidos. }\end{array}$ \\
\hline
\end{tabular}

\section{Subsídio da investigação temática à construção de redes conceituais prévias}

A fim de localizar o leitor sobre as diferentes estratégias, complementares entre si, que foram elaboradas, implementadas e analisadas durante a investigação temática, trazemos para apreciação da comunidade de pesquisadores em Educação em Ciências duas delas, em razão da limitação de espaço para a escrita deste texto. Desse modo, analisamos tais atividades tendo como parâmetro os planos de aula elaborados, desenvolvidos e informados nos registros.

ATIVIDADE (X) - Plano de aula - investigar o pensamento dos envolvidos a partir da construção de um texto.

\section{Cabeçalhos da Universidade e da Escola}

Plano de aula no:

Acadêmico/estagiário:

Data:

Tema da aula: investigação temática - subsídios para a elaboração do plano de curso e da rede conceitual prévia. 


\section{Objetivos}

Geral: investigar e compreender o que pensam os envolvidos sobre a temática "Eletromagnetismo e Tópicos de Ondulatória", tendo como pano de fundo a problemática energética e o aquecimento global, para com isso abrir caminho e problematizar as implicações das relações CTSA.

\section{Específicos:}

- entender a proposta apresentada no GREF (1998) para a elaboração do Plano de Curso da temática "Eletromagnetismo e Tópicos de Ondulatória" no 3o ano do Ensino Médio;

- investigar junto aos envolvidos os objetos técnicos (aparelhos e componentes elétricos e eletrônicos) que conhecem e/ou utilizam, com o intuito de elaborar o Plano de Curso para a referida temática para o Ensino Médio;

- fazer relações entre as categorias físicas e os objetos técnicos (aparelhos e componentes elétricos e eletrônicos), com os vídeos e a temática mencionada, tendo como pano de fundo a problemática energética e o aquecimento global.

Cronologia: 50 minutos.

Procedimentos Metodológicos:

- Perguntar, problematizar e orientar os alunos.

Recursos didáticos:

- TV multimídia; pen drive; vídeos; quadro negro e giz.

Organização do ambiente de ensino/aprendizagem

\section{Atividades:}

\section{- Problematização inicial}

Diante das aulas que já tivemos: com a exposição e discussão dos três vídeos e do filme Ilha das Flores; da relação que fizemos juntos de objetos que vocês conhecem ou utilizam, bem como da classificação em categorias físicas que fizemos na última aula, que relações vocês percebem nisso tudo?

\section{- Organização do conhecimento:}

1 - Orientar os alunos para a realização da atividade: elaborar um texto com as categorias físicas e os vídeos das aulas passadas, relacionando-os com a temática "Eletromagnetismo e Tópicos de Ondulatória", tendo como pano de fundo a problemática energética e o aquecimento global, por um lado, bem como a concepção de ser humano e de geração de lixo, por outro.

Obs.: se necessário, mostrar os dois primeiros vídeos da $1^{\underline{a}}$ aula sobre o aquecimento global.

2 - Depois, solicitar aos alunos que escolham uma das categorias físicas relacionadas abaixo, para escrever um texto:

a) Aparelhos resistivos.

b) Motores elétricos.

c) Elementos de sistema de comunicação e informação. 
d) Semicondutores.

e) Aparelhos elétricos e eletrônicos.

f) Conceitos.

g) Outros.

3 - E solicitar aos alunos que elaborem o texto fazendo relações entre a categoria física (aparelhos e componentes elétricos e eletrônicos) escolhida, os vídeos e a temática já referida, também tendo como pano de fundo tal problemática.

- Aplicação do conhecimento:

- Abrir as discussões sobre o conteúdo de cada texto e confrontá-los com os demais grupos.

Avaliação: será considerado satisfatório se os alunos conseguirem elaborar o texto com alguns dos objetos citados pelos envolvidos dentro da categoria física escolhida.

Frente à problematização a partir da exibição de três vídeos e de um filme feita anteriormente, nessa atividade " $\mathrm{X}$ " os alunos do Ensino Médio foram orientados a fazer um texto no qual eles se mostrassem mais, falando a respeito das questões abordadas, de modo a subsidiarem mais a construção da rede conceitual prévia e, por extensão, da investigação temática, pois as revelações na mídia das constatações realizadas pelo IPCC contribuíram para planejarmos, de modo que elaborássemos duas atividades na primeira semana da investigação temática, realizadas nas escolas nas turmas de Ensino Médio em que nossos licenciandos-estagiários desenvolvem seus estágios.

Os resultados das pesquisas do IPCC, sintetizados em três vídeos de curta duração (inferiores a 10 minutos), são ricos em detalhes, ilustrações e posicionamentos por parte de representantes da ciência e da tecnologia. $\mathrm{O}$ acesso aos vídeos foi (e ainda é) possível a partir de buscas na internet, com especial enfoque dado aos telejornais de TV aberta, tal como realizamos em nosso trabalho.

A problematização e a exibição desses vídeos permitiram a iniciação da codificação (Freire, 1983), necessária para a investigação temática, sendo a problemática energética e o aquecimento global objetos da codificação. Os diferentes posicionamentos emanados dos alunos do Ensino Médio, tais como aqueles apresentados ao assistirem Caos no Clima (Climate Chaos, produzido pela rede BBC-Londres), exibido desde 2007 por diferentes TVs abertas no Brasil, nos permitiram obter dos alunos as seguintes informações: " a mudança de comportamento na aquisição de bens de consumo, 
como adquirir aqueles que são produzidos o mais próximo possível, e o uso da energia elétrica deve ser racional, tanto nas residências quanto em lugares públicos; bem como o uso de energias alternativas aos combustíveis fósseis.

Se por um lado os vídeos permitiram codificar, por outro, a descodificação necessária para nosso entendimento sobre o pensar dos envolvidos começou a se acentuar a partir da geração de informações dos alunos, necessárias à construção das redes conceituais, ainda que não da maneira que desejávamos.

Também, a utilização do curta-metragem Ilha das Flores, de Jorge Furtado (1989), como um recurso de dramatização permitiu evidenciar nos alunos algumas percepções mais efetivas sobre o conceito de ser humano e sua função social no planeta. Além disso, o filme fixou a atenção dos alunos do Ensino Médio sobre as concepções apresentadas até então sobre: consumo e a transformação de bens; as trocas que fomentam o mercado; as unidades e grandezas que distinguem os bens e as respectivas trocas destes. Do ponto de vista formativo, o filme permitiu aos acadêmicos/estagiários perceber os conceitos unificadores: transformações, regularidades, escalas e energia - analisados por Angotti (1992).

E isto, de acordo com um de nossos referenciais teóricos, implica dizer que a mudança do curso da própria ação do indivíduo que vive em sociedade depende necessariamente das nossas ações no mundo e da influência que temos sobre os outros indivíduos, mas que a partir deles também somos influenciados e influenciamos (Strauss, 1999). Em se tratando da problemática energética, do aquecimento global e da geração de lixo e as consequências destes, é impossível pensar as ações locais, individuais, sem as suas implicações globais (Richardson; Blades, 2002).

ATIVIDADE (Y) - Plano de aula - investigar o pensar dos envolvidos sobre o Livro Didático e sobre duas questões do Enem/2007.

\section{Cabeçalhos da Universidade e da Escola}

Plano de aula no:

Acadêmico/estagiário:

Data:

Tema da aula: investigação temática - análise do livro didático e resolução de questões do Enem/2007 


\section{Objetivos}

Geral: investigar e compreender o que pensam os envolvidos sobre a temática "Eletromagnetismo e Tópicos de Ondulatória", tendo como pano de fundo a problemática energética e o aquecimento global, para com isso abrir caminho e problematizar as implicações das relações CTSA.

\section{Específicos:}

- investigar o pensar dos envolvidos sobre: a importância do livro didático no processo ensino/aprendizagem na disciplina de Física;

- investigar o pensar dos envolvidos tendo como parâmetro algumas provocações advindas de questões do Enem/2007 e que podem nos informar o grau de entendimento inicial dos alunos sobre as questões energéticas e o aquecimento global.

Cronologia: 100 minutos.

Procedimentos Metodológicos:

- perguntar, problematizar e orientar os alunos.

\section{Recursos didáticos:}

Livro didático; prova do Enem/2007; quadro verde e giz.

\section{Organização do ambiente de ensino-aprendizagem}

\section{Atividades:}

\section{- Problematização inicial}

Ler o texto:

"Álcool, crescimento e pobreza"

O lavrador de Ribeirão Preto recebe em média $\mathrm{R} \$ 2,50$ por tonelada de cana cortada. Nos anos 80 , esse trabalhador cortava cinco toneladas de cana por dia. A mecanização da colheita o obrigou a ser mais produtivo. O corta-cana derruba agora oito toneladas por dia. $\mathrm{O}$ trabalhador deve cortar a cana rente ao chão, encurvado. Usa roupas mal-ajambradas, quentes, que lhe cobrem o corpo, para que não seja lanhado pelas folhas da planta. O excesso de trabalho causa a birola: tontura, desmaio, cãibra, convulsão. A fim de aguentar dores e cansaço, esse trabalhador toma drogas e soluções de glicose, quando não farinha mesmo. Tem aumentado o número de mortes por exaustão nos canaviais. O setor da cana produz hoje uns 3,5\% do PIB. Exporta US $\$ 8$ bilhões. Gera toda a energia elétrica que consome e ainda vende excedentes. A indústria de São Paulo contrata cientistas e engenheiros para desenvolver máquinas e equipamentos mais eficientes para as usinas de álcool. As pesquisas, privada e pública, na área agrícola (cana, laranja, eucalipto etc.) desenvolvem a bioquímica e a genética no país.

Fonte: Folha de S. Paulo, 11/3/2007. Veiculado no Enem/2007 (com adaptações e grifos nossos).

Lido o texto, pedir que alguém comente o seu conteúdo:

- Organização do conhecimento:

1 - Fazer apresentação, discussão e análise do livro didático de Física que será utilizado com os envolvidos durante o ano letivo (40 minutos). 
2 - Os alunos resolveram questões do Enem/2007, sendo que elas envolvem algumas implicações CTSA levantadas nas aulas anteriores (50 minutos).

Obs.: a modificação que fizemos nas questões do Enem/2007 se refere tão somente à justificativa que o aluno deverá dar a resposta que apontou.

- Questão 40 - Enem/2007 - amarela - (modificada).

Nos últimos 50 anos, as temperaturas de inverno na península antártica subiram quase $6^{\circ} \mathrm{C}$. Ao contrário do esperado, o aquecimento tem aumentado a precipitação de neve. Isso ocorre porque o gelo marinho, que forma um manto impermeável sobre o oceano, está derretendo devido à elevação de temperatura, o que permite que mais umidade escape para a atmosfera. Essa umidade cai na forma de neve. Logo depois de chegar a essa região, certa espécie de pinguim precisa de solos nus para construir seus ninhos de pedregulhos. Se a neve não derrete a tempo, eles põem seus ovos sobre ela. Quando a neve finalmente derrete, os ovos se encharcam de água e goram.

Fonte: Scientific American Brasil, ano 2, no 21, 2004, p.80 (com adaptações).

A partir do texto acima, analise as seguintes afirmativas:

I. O aumento da temperatura global interfere no ciclo da água na península antártica.

II. O aquecimento global pode interferir no ciclo de vida de espécies típicas de região de clima polar.

III. A existência de água em estado sólido constitui fator crucial para a manutenção da vida em alguns biomas.

É correto o que se afirma

a) apenas em I; b) apenas em II; c) apenas em I e II; d) apenas em II e III; e) em I, II e III.

Justifique a sua resposta:

- Questão 47 - Enem/2007 - amarela (modificada).

O uso mais popular de energia solar está associado ao fornecimento de água quente para fins domésticos. Na figura ao lado, é ilustrado um aquecedor de água constituído de dois tanques pretos dentro de uma caixa termicamente isolada e com cobertura de vidro, os quais absorvem energia solar.

Nesse sistema de aquecimento,

a) os tanques, por serem de cor preta, são maus absorvedores de calor e reduzem as perdas de energia.

b) a cobertura de vidro deixa passar a energia luminosa e reduz a perda de energia térmica utilizada para o aquecimento.

c) a água circula devido à variação de energia luminosa existente entre os pontos $\mathrm{XeY}$. 
d) a camada refletiva tem como função armazenar energia luminosa.

e) o vidro, por ser bom condutor de calor, permite que se mantenha constante a temperatura no interior da caixa.

Justifique a sua resposta:

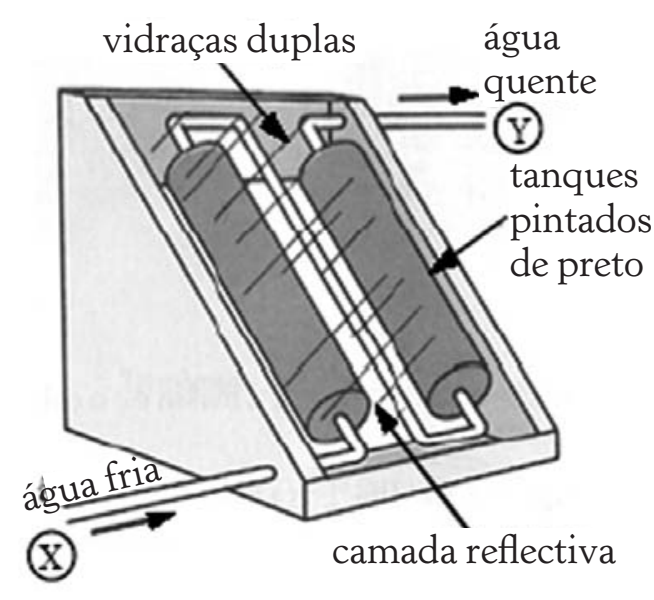

Fonte: A. Hinrichs e M. Kleinbach. Energia e meio ambiente. São Paulo: Thompson, 3 a ed., 2004, p.529 (com adaptações).

\section{- Aplicação do conhecimento:}

Com os subsídios dos três vídeos apresentados e o filme Ilha das Flores, trabalhados em aulas anteriores, a lista de objetos citados e classificados pelos envolvidos e as discussões em sala de aula, solicitar aos alunos que justifiquem as respostas para cada uma das questões da prova do Enem/2007.

Avaliação: será satisfatório se os alunos conseguirem justificar as suas respostas, relacionando temas: como efeito estufa e aquecimento global com implicações energéticas e socioambientais.

As evidências destacadas nos três vídeos e no filme Ilha das Flores, de Jorge Furtado, foram tratadas pelos alunos do Ensino Médio (e por que não dizer pelos acadêmicos/estagiários também) sob o ponto de vista mais interpretativo, a partir do que propunha o Plano de Aula representado na atividade "X"; mas sobre os mesmos vídeos e o filme, o tratamento não foi esse na atividade "Y". Nesta, a objetividade das questões do Enem (2007) suscitaram o interesse mais direto dos alunos do Ensino Médio sobre o que pensam das aulas de Física, principalmente em se tratando da investigação temática - que para alguns desses alunos e pelos acadêmicos-estagiários tem sido rotulada como perda de tempo ou algo muito próximo disso, com justificativas de ambos os lados, pois de alunos do Ensino Médio aparecem indagações tais como: Quando vai começar o conteúdo de Física?, 
ou [...] o professor está enrolando, e por que não começa logo?, e, por parte dos acadêmicos/estagiários apareceram exclamações favoráveis a essa linha de raciocínio dos alunos do Ensino Médio, tais como: Os alunos querem que eu comece logo com o conteúdo!, ou Eles querem questões que caem no vestibular!.

Ambos os sujeitos se sentem aparentemente mais seguros quando são colocados à frente de uma situação tradicionalmente conhecida - uma prova, como a do Enem. Isso é só aparente, porque a dimensão de questões como aquelas destacadas na atividade "Y", de fácil tratamento matemático, levam ambos - alunos do Ensino Médio e acadêmicos/estagiários - para uma dificuldade de posicionamento, quando tais questões propostas solicitam justificativas e até tomadas de posição. Daí a razão da modificação que nelas fizemos, pedindo a justificativa para cada questão.

É nesse momento que ambos precisam despir-se das concepções equivocadas arraigadas sobre o processo ensino-aprendizagem. É um momento em que eles são colocados em uma situação paradoxal: se por um lado admitem que o tempo dado à condução da investigação temática deve dar lugar ao início do conteúdo, até mesmo com urgência, sob a alegação de que os alunos do Ensino Médio possam ter êxito nas suas avaliações (provas como as do Enem); por outro, por que é que avaliações como a do Enem precisam ser pensadas de acordo com o que se procedeu desde o início até o presente momento na investigação temática?

\section{Resultados e considerações finais}

A realização da investigação temática culmina com a construção da(s) rede(s) conceituais prévias das temáticas de Física a serem ensinadas/ aprendidas no Ensino Médio, tendo como fundamento a escolha de um (ou mais) objeto técnico, objetivando transformá-lo em equipamento gerador (De Bastos, 1995; Mion; Angotti, 2001), sob critérios objetivos de seleção de tal objeto.

Finalizadas essas atividades nessas seis semanas, foi possível configurar as redes conceituais prévias, cada uma parametrizada por um objeto técnico diferente. A seguir, traremos apenas uma figura, mas que retrata as redes conceituais construídas pelos acadêmicos/estagiários, sob orientação 
do professor supervisor de estágio, a partir das atividades de investigação temática desenvolvidas. É preciso dizer que as redes conceituais são denominadas prévias porque entendemos que a investigação temática continua sendo em cada aula, em cada atividade educacional planejada, desenvolvida e analisada semanalmente, bimestralmente e no decorrer do ano letivo, mas também por considerarmos o fato de que durante a ação (Strauss, 1999) podem ser gerados alguns desdobramentos que requerem e, portanto, autorizam a se fazer, mudanças no desenvolvimento da rede - é a mudança do curso da ação, fazendo com que se reconstrua a história da própria prática.

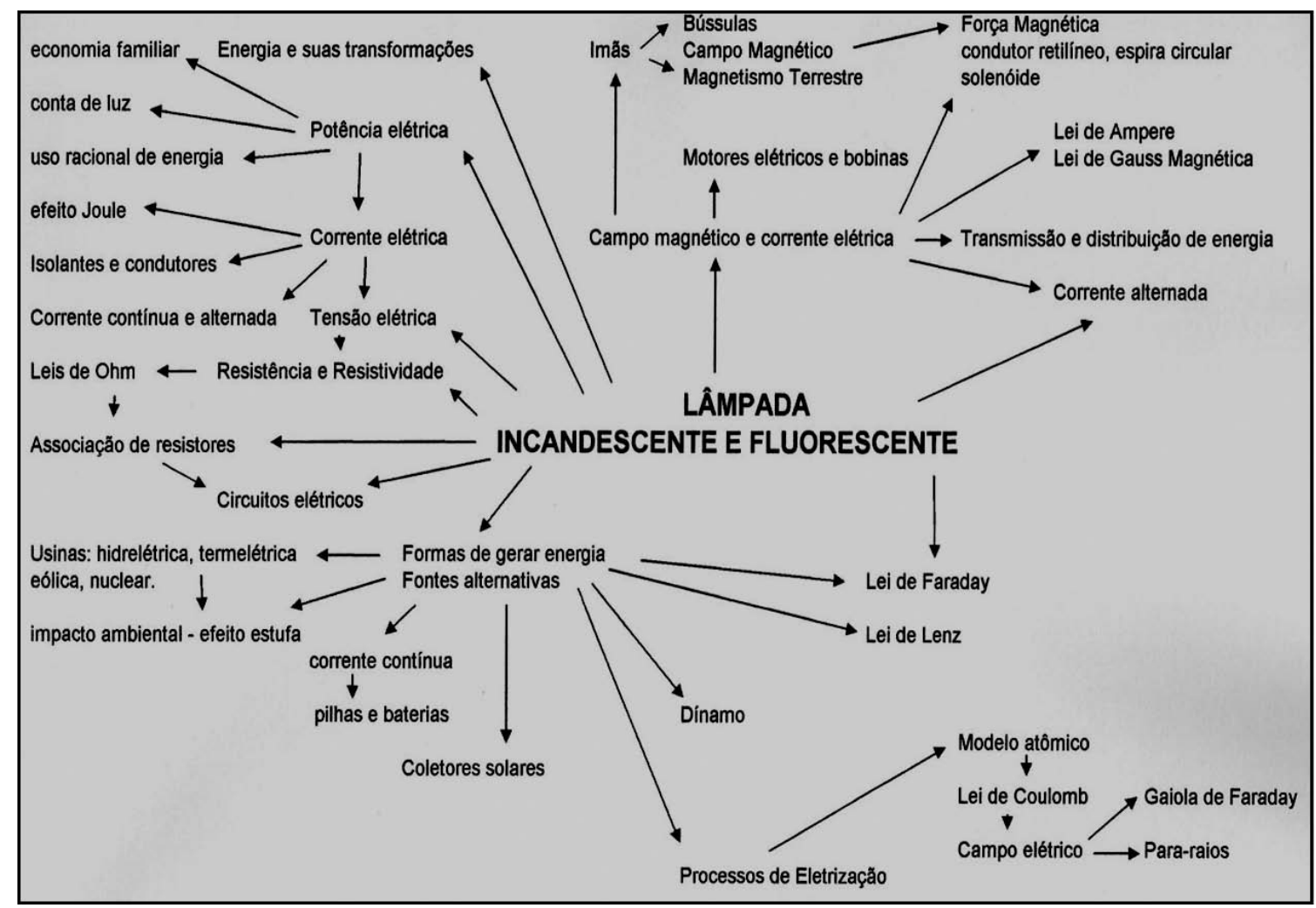

Figura 2 - Rede conceitual prévia para a temática "Eletromagnetismo e Tópicos de Ondulatória".

A figura 2 apresenta um número grande de conceitos e fenômenos físicos, além dos conteúdos mínimos, mas não apresenta a equivalência necessária com interesses à problematização das implicações da relação CTSA. Do mesmo modo, não são mostrados detalhamentos sobre as implicações dessa relação, mesmo tendo sido solicitado isso, ou seja, apresentam-se de modo pontual alguns elementos, como: impacto ambiental, telefonia celular, transmissão de TV, conta de luz e economia familiar. Isso é um indi- 
cativo de que as linhas e malhas da rede conceitual podem e precisam ser alteradas no curso da ação (Strauss, 1999), o que é permitido na formação docente do ponto de vista epistemológico, justificando assim a terminologia "prévia" para a rede conceitual. Então, planejar a investigação temática em Física sob o foco da problematização das implicações da relação CTSA, mas desprovida de tal investigação da obtenção de uma rede conceitual como resultado dessa vivência, seria conjeturar no vazio, descaracterizada, portanto, de um suporte epistemológico.

A construção dessas redes conceituais (prévias) tem apresentado importantes indicativos: (a) no Estágio Curricular Supervisionado em Ensino de Física é a primeira vez que os licenciandos têm contato e iniciam o aprendizado de como fazê-las durante sua vivência no curso de licenciatura; (b) de modo similar, é revelado por eles que também é nessa disciplina que questões de natureza tecnológica e socioambientais são tensionadas em sua formação docente.

Defendemos que a relevância da investigação temática para a formação inicial do professor de Física é indispensável, se o professor incorpora uma visão crítica de Educação. E, incorporada essa visão de educação, é impensável omitir-se da responsabilidade de problematizar as implicações da relação CTSA.

\section{Referências bibliográficas}

ANGOTTI, J. A. P. Conceitos Unificadores e Ensino de Física. Revista Brasileira de Ensino de Física. São Paulo, v.15, n.1-4, pp.191-198, 1995.

CARR, W.; KEMMIS, S. Teoria crítica de la enseñanza: investigación-acción en la formación del profesorado. Trad.: J. A. Bravo. Barcelona: Martinez Roca, 1988.

CLIMATE C. BBC, London: BBC, 2007. Tradução e adaptação: Rede Globo, 2007.

DE BASTOS, F. P. Pesquisa-Ação Emancipatória e Prática Educacional Dialógica em Ciências Naturais. 1995. Tese (Doutorado em Educação) - Faculdade de educação. Universidade de São Paulo, São Paulo, 1995.

DE MEIS, L. Ciência, Educação e o Conflito Humano-Tecnológico. São Paulo: Editora Senac, 2000.

ENEM. Exame Nacional do Ensino Médio. Brasília, 2007.

FREIRE, P. Conscientização. São Paulo: Moraes, 1980. . Pedagogia do Oprimido. 15. ed. Rio de Janeiro: Paz e Terra, 1983. 
GREF. Grupo de Reelaboração do Ensino de Física. Física. v.1, 2 e 3. São Paulo: Edusp, 1998.

ILHA DAS FLORES. Produção de Jorge Furtado. Porto Alegre: Casa do Cinema, 1989.

LATOUR, Bruno. Jamais Fomos Modernos. Trad.: Carlos Irineu da Costa. Rio de Janeiro: Ed. 34, 1994.

Ciência em Ação. Trad.: Ivone C. Benedetti. São Paulo: Ed. Unesp, 2000.

MION, R. A. Investigação-Ação e a Formação de Professores em Física: o papel da intenção na produção do conhecimento crítico. 2002. 238 f.. Tese (Doutorado em Educação) - Universidade Federal de Santa Catarina, Florianópolis, 2002. ; ANGOTTI, J. A. P. Equipamentos Geradores e a Formação de Professores de Física. In: ANGOTTI, J. A. P.; REZENDE JUNIOR, M. F. (Orgs.). Prática de Ensino de Física. Florianópolis, Laboratório de Ensino de Física à Distância, pp.91-116, 2001.

PEDRETTI, E. G. et al. Promoting Issues-based STSE Perspectives in Science Teacher Education: Problems of Identity and Ideology. Science $\mathcal{E}$ Education. London, v.17, pp.941-960, 2008.

RICHARDSON, G.; BLADES, D. Social Studies and Science Education: developing world citizenship through interdisciplinary partnerships. Quasar. Alberta (Canada), 2002. Disponível em: http://www.quasar.ualberta.ca/css/ Css_35_3. Acesso em: 20 jan. 2002.

STRAUSS, Anselm L. Espelhos e Máscaras: a busca de identidade. Trad.: Geraldo Gerson de Souza. São Paulo: Edusp, 1999. 


\title{
2 \\ As ATIVIDADES DE CAMPO NO ENSINO dE CIÊNCIAS: REFLEXÕES A PARTIR DAS PERSPECTIVAS DE UM GRUPO DE PROFESSORES
}

\author{
Alessandra Aparecida Viveiro ${ }^{1}$ \\ Renato Eugênio da Silva Diniz ${ }^{2}$
}

\section{Introdução}

A diversificação das modalidades didáticas na prática pedagógica pode atender a distintas necessidades e interesses dos alunos e contribuir para motivá-los e envolvê-los no processo de ensino/aprendizagem. A motivação é fundamental para que ocorra uma aprendizagem significativa e, além disso, não há um único caminho que conduza com segurança à aprendizagem, pois são inúmeras as variáveis que se interpõem nesse processo. Assim, o pluralismo de estratégias pode garantir maiores oportunidades para a construção do conhecimento ao fornecer aos alunos diferentes abordagens do conteúdo, ou seja, os alunos vivenciam um maior número de atividades que melhor os ajudem a compreender o tema estudado (Sanmartí, 2002; Bueno, 2003).

Dentre as diversas estratégias a que o professor da área das Ciências pode recorrer (aulas expositivas, discussões, demonstrações, aulas práticas de laboratório, entre outras), a atividade de campo pode constituir uma excelente alternativa metodológica que permite explorar múltiplas possibilidades de aprendizagem dos alunos, desde que bem planejada e elaborada.

1 Doutoranda do Programa de Pós-Graduação em Educação para a Ciência, Faculdade de Ciências, campus de Bauru, da Universidade Estadual Paulista "Júlio de Mesquita Filho" (Unesp). Grupo de Pesquisa Formação e Ação de Professores de Ciências e Educadores Ambientais.

2 Docente do Departamento de Educação, Instituto de Biociências e do Programa de Pós-Graduação em Educação para a Ciência. Faculdade de Ciências, campus de Bauru, da Universidade Estadual Paulista Júlio de Mesquita Filho (Unesp). Grupo de Pesquisa Formação e Ação de Professores de Ciências e Educadores Ambientais. 
Deste modo, a presente pesquisa teve como objetivo geral identificar e problematizar como um grupo de professores insere a Visita Científica à Bacia Hidrográfica do Rio Itaqueri - uma atividade de campo monitorada promovida pelo Centro de Divulgação Científica e Cultural da Universidade de São Paulo (CDCC/USP) - em sua prática pedagógica, visando discutir o papel das atividades de campo como estratégia no ensino das Ciências e na Educação Ambiental (EA). Para tanto, os seguintes objetivos específicos foram definidos: identificar o que motiva os professores a realizar uma atividade de campo e como a inserem em sala de aula, investigando se existe relação com os conteúdos programáticos; investigar se essas atividades mobilizam professores de diferentes áreas na exploração de suas potencialidades ou restringem-se ao universo do professor que sai a campo com seus alunos; conhecer os entraves com os quais se deparam esses professores.

\section{As atividades de campo no processo educativo}

Fernandes (2007, p.22) define atividade de campo em Ciências como "toda aquela que envolve o deslocamento dos alunos para um ambiente alheio aos espaços de estudo contidos na escola".

Quando nos referimos às atividades de campo no ensino de Ciências, nos reportamos à ideia de uma estratégia de ensino em que se substitui a sala de aula por outro ambiente, natural ou não, onde existam condições para estudar as relações entre os seres vivos ali presentes, incluindo a interação do homem nesse espaço, explorando aspectos naturais, sociais, históricos, culturais, entre outros. Pode ocorrer em um jardim, uma praça, um museu, uma indústria, uma área de preservação, um bairro, incluindo desde saídas rápidas ao entorno da escola até viagens que ocupam vários dias.

É interessante mencionar que, embora o contato direto do aluno com o ambiente na educação escolar soe como uma modalidade nova, graças a sua tímida inserção como prática pedagógica, sua utilização teve início há um tempo considerável. No cenário internacional, em 1946, o Field Studies Council of Britain fundou o primeiro centro objetivando desenvolver trabalhos de campo em uma perspectiva educacional. Foi o movimento da Escola Nova que formalizou e sistematizou uma proposta concreta para que os trabalhos de campo figurassem como proposta pedagógica, quando o estu- 
do do meio passou a ser aceito como importante componente no processo educacional e as atividades de campo ganharam destaque (Morrison, 1974; Carson, 1978 apud Carvalho, 1989).

No Brasil, o estudo do meio teve início no final da década de 1950, com a instalação das classes experimentais, em determinadas escolas públicas e privadas, baseadas em uma portaria do Ministério da Educação e Cultura, e a expressão máxima veio com o surgimento dos Ginásios Vocacionais e Colégios de Aplicação, no início da década de 1960 (Balzan, 1987).

Muitos autores ressaltam as potencialidades das atividades de campo. Carbonell (2002), citando Gardner (2000), discute que a mente tem a capacidade de aprender e reter melhor as informações quando o corpo interage de maneira ativa na exploração de lugares, enquanto experiências em que o sujeito é passivo tendem a ter impacto de curta duração e atenuam-se com o tempo. Assim, afirma que

são necessários espaços físicos, simbólicos, mentais e afetivos diversificados e estimulantes (...), aulas fora da classe, em outros espaços da escola, do campo e da cidade. Porque o bosque, o museu, o rio, o lago (...), bem aproveitados, convertem-se em excelentes cenários de aprendizagem (Carbonell, 2000, p.88).

As atividades de campo permitem o contato direto com o ambiente, possibilitando que o estudante se envolva e interaja em situações reais, confrontando teoria e prática, além de estimular a curiosidade e aguçar os sentidos. Além disso, uma atividade de campo permite que "o aluno se sinta protagonista de seu ensino, que é um elemento ativo e não um mero receptor de conhecimento" (De Frutos et al., 1996, p.15).

Para além de conteúdos específicos, uma atividade de campo permite também estreitar as relações de estima entre o professor e seus alunos, favorecendo um companheirismo resultante da experiência em comum e da convivência agradável entre os sujeitos envolvidos que perdura na volta ao ambiente escolar.

Entretanto, embora possam fornecer importantes contribuições à educação escolar, a forma como são desenvolvidas pode limitar a exploração plena das potencialidades que as caracterizam. Em muitas atividades de campo, o estudante se vê parte de processos semelhantes aos que se estabelecem no interior das salas de aula, havendo quase uma transferência 
das aulas expositivas para fora da classe. Atividades educativas nas quais o educando interage com o ambiente, de modo que as características do meio sejam de fato fundamentais para a atividade e não apenas configurem um cenário distante, um palco que pode ser substituído por outro qualquer, necessitam de reflexão para que sejam práticas qualitativamente mais empregadas (Pegoraro, 2003).

É importante salientar que uma atividade de campo compreende não só a saída propriamente dita, mas as fases de planejamento, execução, exploração dos resultados e avaliação. Limitar essa atividade apenas à visita constitui-se em um desperdício das potencialidades passíveis de serem trabalhadas por meio dessa modalidade didática.

Lopes e Allain (2002) lembram que a complexidade que envolve uma atividade de campo, em que os educandos se deparam com uma grande quantidade de fenômenos que ainda não compreendem, pode confundilos na construção do conhecimento; lidar com essa complexidade requer o prévio estabelecimento de objetivos claros, além de um educador bem preparado. O professor "deve conhecer o produto e o processo que se dispõe a compartilhar com seus estudantes" (Bueno, 2003, p.50). Sobretudo, os alunos devem saber que a saída não é apenas lazer, mas outra forma de aprender e conhecer lugares, novos ou não (Carvalho, 1989).

A escolha do local para uma aula de campo também é importante. Quanto maior for a diversidade do ambiente escolhido para o estudo, maior a gama de conteúdos que poderão ser tratados, enriquecendo-se assim o contexto das aulas (Carvalho, 1989). No caso das visitas monitoradas oferecidas por uma instituição, com um itinerário predeterminado, o trabalho do educador é aparentemente facilitado, uma vez que se supre a necessidade de que conheça detalhadamente todo o ambiente visitado. Entretanto, De Frutos, juntamente com outros autores (1996), lembra que, frequentemente, o conteúdo abordado durante uma visita desse tipo não é totalmente adequado aos objetivos de cada série e de cada professor. Portanto, sugere que o educador aproveite as informações trabalhadas pelos guias ou monitores e proponha tarefas a serem realizadas durante a atividade de campo, de modo a adequar ao máximo a visita às suas necessidades.

As atividades de campo podem ser utilizadas também como importante estratégia em programas de EA, uma vez que o contato com o ambiente permite a sensibilização acerca dos problemas ambientais. Além disso, sur- 
gem oportunidades de reflexão sobre valores, imprescindíveis às mudanças comportamentais e, sobretudo, atitudinais (Carvalho, 1998).

Assim, uma caminhada nos arredores da escola, por exemplo, pode constituir uma ótima atividade para desencadear um programa de EA a partir da observação e exploração dos problemas locais. Conhecimentos de todas as áreas podem ser acionados para a compreensão e a discussão sobre o entorno ambiental. É importante salientar que o ensino interdisciplinar no campo ambiental deve focar o "estudo das relações entre processos naturais e sociais, dependendo da capacidade das Ciências para articular-se, oferecendo uma visão integradora da realidade" (Leff, 2001, p.228). Nessa perspectiva, a interdisciplinaridade "se traduz como um trabalho coletivo que envolve conteúdos, disciplinas e a própria organização da escola" (Loureiro, 2004, p.76).

Para que isso se concretize, no entanto, não é possível pensar em EA no currículo dos diferentes componentes curriculares, inclusive em Ciências, como um apêndice - onde o ambiente é visto como um complemento dos conteúdos programáticos convencionais -, ou como eixo paralelo-onde os conteúdos ambientais são abordados por meio de projetos extracurriculares de forma paralela e desconexa. É preciso pensar a EA como eixo integrador, tomando-se "o ambiente como tema gerador, articulador e unificador, programático e metodológico, de todo o currículo de Ciências" (Amaral, 2001, p.90).

Ao pensar em EA como uma prática educativa, é preciso inserir as atividades de campo dentro de um horizonte onde o ambiental "é pensado como sistema complexo de relações e interações da base natural e social e, sobretudo, definido pelos modos de sua apropriação pelos diversos grupos, populações e interesses sociais, políticos e culturais que aí se estabelecem" (Carvalho, 2001, p.45). Nesse contexto, há uma nova ênfase para a educação escolar diante da necessidade de repensar as relações entre sociedade e natureza, quando as atividades de campo são

[...] fundamentais à compreensão das questões ambientais em sua complexidade, propiciando uma visão articulada das diferentes esferas de repercussão de um problema ambiental em estudo. Isto favorece a compreensão dos problemas socioambientais na escola, bem como contribui para a formação de cidadãos críticos e participativos em busca da melhoria da qualidade de vida (Santos; Compiani, 2005, p.2). 
Desse modo,

[...] apoiados na observação direta da realidade (...), os alunos podem fazer uma releitura crítico-construtiva [da] (...) realidade, identificar seus problemas socioambientais, estabelecer relações entre as informações levantadas, bem como elaborar propostas para a transformação da mesma (op. cit., p.5).

\section{A visita científica à Bacia Hidrográfica do Rio Itaqueri}

O Programa de Visitas foi criado em 1986, como sugestão de um grupo de professores que participavam de um curso de formação continuada oferecido pelo CDCC/USP em conjunto com o Centro de Recursos Hídricos e Ecologia Aplicada (CRHEA/EESC/USP). As atividades de campo eram uma das estratégias utilizadas no curso que utilizava como área de estudo a Bacia Hidrográfica do Rio Itaqueri (Tundisi; Schiel, 2003). No decorrer do tempo, diversas reestruturações foram realizadas, com a criação de materiais de apoio ao professor, maquetes e fichas de avaliação, além de alterações no roteiro.

A atividade é realizada em uma área rural pertencente às cidades de São Carlos, Itirapina e Brotas, no interior do Estado de São Paulo, onde os participantes têm contato com diferentes ambientes (cerrado, monocultura de vegetação exótica, mata ciliar e diversos corpos d'água) e os impactos causados pela ocupação humana, fornecendo elementos para reflexões sobre problemas ambientais relacionados a diversos temas, como a degradação das matas nativas para exploração agropecuária, impactos ocasionados pela substituição da mata nativa (cerrado) por uma monocultura exótica (Pinus $s p)$, a construção de uma represa, entre outros aspectos. Também se visita um criadouro conservacionista, onde os estudantes podem conhecer animais silvestres nativos ameaçados de extinção (Santos; Viveiro; Silva, 2002).

Os professores recebem um material de apoio e preenchem uma ficha de inscrição que contém informações como, por exemplo, quais objetivos pretendem alcançar, como pretendem trabalhar o assunto em sala de aula, quais os temas que gostariam que fossem abordados e de que forma costumam avaliar seus alunos mediante o que foi visto durante a visita, para que os monitores saibam com antecedência sobre o público com o qual irão trabalhar. Ao final da visita, o professor preenche uma ficha de avaliação onde são colocados os pontos positivos e negativos observados, sua opinião sobre 
a adequação da linguagem utilizada e alcance dos seus objetivos, entre outros fatores. Os monitores também preenchem uma ficha, apontando itens como a participação dos alunos e professores, interesse, problemas ocorridos etc.. Todo o material é arquivado no setor responsável pela atividade.

\section{Metodologia}

A pesquisa foi norteada por uma abordagem qualitativa (Triviños, 1987; Bogdan; Biklen, 1991; Minayo, 2000) e caracterizou-se como um estudo de caso. A visita científica à Bacia Hidrográfica do Rio Itaqueri foi escolhida como foco da pesquisa por ser uma atividade de campo utilizada por muitos professores de diferentes áreas, de São Carlos e também de outros municípios, ao longo de vários anos.

Realizou-se um levantamento dos professores que participavam da atividade com certa assiduidade a partir das fichas de inscrição e avaliação preenchidas por professores e monitores desde o ano de 1995. Foram selecionados nove professores que realizavam a visita há, no mínimo, cinco anos, procurando assegurar que os entrevistados fossem educadores que, sem dúvidas, utilizassem as atividades de campo com certa regularidade em sua prática pedagógica. Minayo (2000, p.102) afirma que, em uma amostragem qualitativa, é importante que os envolvidos "contenham o conjunto das experiências e expressões que se pretende objetivar com a pesquisa".

Após contato e exposição do trabalho, sete professores participaram de entrevistas semiestruturadas. Embora se observe distinção de gênero no grupo de professores (quatro do sexo masculino e três do feminino), isso não foi objeto de análise nessa investigação, que focalizou o grupo no seu conjunto. Para tanto, e de modo a garantir a não identificação dos sujeitos, estes foram nomeados como P1, P2, P3, P4, P5, P6 e P7.

A análise das entrevistas incidiu sobre os seguintes aspectos: como os professores utilizam a visita em sala de aula, incluindo a avaliação da atividade e a interação com outros docentes; qual a motivação para que realizem essa atividade de campo; quais as dificuldades com as quais se deparam para realizá-la. Desenvolveu-se uma narrativa explanatória, utilizando trechos das entrevistas para exemplificação e organizando as principais características em quadros-síntese. 


\section{Resultados e discussão}

\section{Breve caracterização dos docentes}

No Quadro 1, tem-se a formação inicial dos professores que participaram da pesquisa, acompanhada do ano em concluíram o curso em nível de graduação.

Quadro 1 - Formação inicial dos professores.

\begin{tabular}{|c|l|c|}
\hline \multirow{2}{*}{ PROFESSOR } & \multicolumn{2}{|c|}{ GRADUAÇÃO } \\
\cline { 2 - 3 } & \multicolumn{1}{|c|}{ CURSO } & ANO \\
\hline P1 & Ciências Biológicas (Habilitação em Biologia e Ciências) & 1998 \\
\hline P2 & Estudos Sociais (Habilitação em Geografia) & 1991 \\
\hline P3 & Ciências (Habilitação em Química) & 1972 \\
\hline P4 & Pedagogia & 1994 \\
\hline P5 & Ciências (Habilitação em Química) & 1974 \\
\hline \multirow{2}{*}{ P6 } & Ciências Biológicas (Habilitação em Biologia e Ciências) & 1976 \\
\cline { 2 - 3 } & Pedagogia & 1979 \\
\hline P7 & Física & 1985 \\
\hline & \multicolumn{1}{|c|}{} \\
\hline
\end{tabular}

No Quadro 2, estão organizados os dados relacionados à atuação em sala de aula, com ano de ingresso na carreira do magistério, componentes curriculares ministrados e carga horária semanal de trabalho.

Quadro 2 - Atuação em sala de aula.

\begin{tabular}{|c|c|c|c|c|}
\hline \multirow[t]{2}{*}{ PROFESSOR } & \multirow{2}{*}{$\begin{array}{c}\text { INÍCIO DA } \\
\text { ATUAÇÃO } \\
\text { EM SALA } \\
\text { DE AULA }\end{array}$} & \multicolumn{2}{|c|}{$\begin{array}{c}\text { COMPONENTE(S) } \\
\text { CURRICULAR(ES) } \\
\text { MINISTRADO(S) }\end{array}$} & \multirow{2}{*}{$\begin{array}{l}\text { CARGA } \\
\text { HORÁRIA } \\
\text { SEMANAI } \\
\text { (horas/aula) }\end{array}$} \\
\hline & & $\mathrm{EF}$ & EM & \\
\hline P1 & 2000 & Ciências & Biologia & 25 \\
\hline $\mathrm{P} 2$ & 1992 & Geografia & - & 27 \\
\hline $\mathrm{P} 3$ & 1973 & Ciências & Química & 60 \\
\hline \multirow[b]{2}{*}{ P4 } & \multirow[b]{2}{*}{1992} & \multirow[b]{2}{*}{-} & Didática & \multirow[b]{2}{*}{29} \\
\hline & & & $\begin{array}{l}\text { Conteúdos Metodológicos } \\
\text { de Língua Portuguesa }\end{array}$ & \\
\hline P5 & 1975 & Ciências & Química & 33 \\
\hline P6 & 1976 & Ciências & Biologia & variável \\
\hline P7 & 1982 & $\begin{array}{l}\text { Ciências } \\
\left.\text { ( } 8^{a} \text { série }\right)\end{array}$ & Física & 56 \\
\hline
\end{tabular}


Observa-se um predomínio dos professores com muitos anos de carreira e formação inicial diversificada. Os componentes curriculares ministrados pelos professores eram variados, atuando no Ensino Fundamental (EF) e Médio (EM) - aqueles citados por $\mathrm{P} 4$ referem-se à grade curricular do agora extinto Centro de Formação e Aperfeiçoamento do Magistério (Cefam). A carga horária semanal de alguns professores era excessiva - caso de P3 e P7. Aposentado, P6 atuava em caráter eventual, não tendo por isso uma carga horária fixa.

\section{Inserção da visita na prática pedagógica}

O contato inicial dos professores com a atividade de campo realizada pelo CDCC/USP foi variado. Os professores P3, P5 e P6 participaram dos cursos que originaram o Programa de Visitas e, disseram ter, desde então, realizado sempre a atividade com seus alunos. Os demais professores - $\mathrm{P} 1$, P2, P4 e P7 - conheceram o Programa por meio de outros professores que já haviam participado da visita. Os professores $\mathrm{P} 4$ e $\mathrm{P} 7$ disseram realizar a visita desde 1999, e os professores P1 e P2, desde 2000. Sem exceção, comentaram que as séries em que trabalhavam e a disponibilidade de tempo e recursos financeiros eram alguns dos fatores que determinavam a realização da atividade. Em geral, todas as classes de uma mesma série em que o professor ministrava aulas realizavam a visita em um mesmo ano.

Algumas falas ilustram a forma como os professores exploram a visita em sala de aula:

Você tem tanto os itens trabalhados em sala de aula como novos itens que aparecem no dia, no campo... (P1)

A gente dá toda teoria em sala de aula, a explicação e tudo mais, e depois a gente leva pra conhecer, pro aluno interagir. (...) No retorno, nas aulas seguintes (...), nós vamos trabalhar de uma forma mais aprofundada. Então, a gente trabatha mais depois da visita. (P2)

Porque você mexe com Ecologia. Aí você fala da mata ciliar, bacia hidrográfca... (...) A professora de Geografia também trabalha essa parte. Então acho que a gente dá mais uma retocada geral pra eles relembrarem... (P5) 
Em síntese, tem-se o seguinte quadro:

Quadro 3 - Inserção da visita científica à Bacia Hidrográfica do Rio Itaqueri na prática pedagógica.

\begin{tabular}{|c|l|}
\hline PROFESSOR & \multicolumn{1}{c|}{ FINALIDADE } \\
\hline P1 - P2 - P3 - P5 & complementação / ilustração / fixação de conteúdos. \\
\hline P3 & oportunidade para trabalhar novos conteúdos (relacionados à visita). \\
\hline P4 & formação de professores. \\
\hline P6 & ponto de partida para exploração de conteúdos. \\
\hline P7 & proporcionar contato com o ambiente natural. \\
\hline
\end{tabular}

Nenhum professor mencionou inserir as atividades de campo como estratégia para trabalhar com EA, apesar das potencialidades já discutidas.

Quando indagados sobre a avaliação das visitas, os professores demonstraram julgar ser uma etapa importante do trabalho, por favorecer o comprometimento dos alunos com o trabalho desenvolvido (P1) e fornecer informações sobre a aprendizagem acerca dos conteúdos abordados durante a atividade. Os professores P2 e P3 estimulavam a produção de materiais para que os estudantes apresentassem ao restante da comunidade escolar aquilo que vivenciaram e aprenderam. Além disso, P3 utilizava como instrumentos de avaliação os trabalhos produzidos a partir da exploração dos dados coletados em campo.

... vamos trabalhar com mais textos, com perguntas sobre o passeio, com atividades que serão expostas, mural de fotografias. (...) Avaliações com atividades que serão expostas na escola. (P2)

Aqui, na sala de aula, eu costumo trabalhar em forma de um gráfico... Um trabalho... Em cartaz... (...) [Depois ] expõe o trabalho... (P3)

Segundo P4, mais que conteúdos específicos, avaliava a criatividade e coerência das propostas apresentadas pelos estudantes de magistério. Já P7 disse não realizar nenhum tipo de avaliação. Apesar disso, foi possível perceber que esta ocorria, ainda que "informalmente". Ao discutir com os alunos sobre os temas abordados na visita, averiguando a satisfação/insatisfação com a atividade, levantar pontos que julgaram mais interessantes etc., o professor poderia avaliar o aproveitamento dos estudantes e perceber conhecimentos construídos acerca dos conteúdos trabalhados. 
No que tange a exploração da visita por outros professores da escola e a interação na equipe escolar para uma abordagem interdisciplinar, somente $\mathrm{P} 2$ e $\mathrm{P} 5$ assinalaram positivamente, indicando que "os conteúdos" eram trabalhados em outros componentes curriculares, o que não implicava que a atividade fosse explorada por outros docentes; os conteúdos abordados durante a visita científica à Bacia Hidrográfica do Rio Itaqueri permeiam, sobretudo, os componentes de Geografia, Biologia, Ciências e, portanto, qualquer professor poderia tratar desses assuntos utilizando-se de outras estratégias. Os demais professores revelaram uma prática pedagógica solitária em relação às atividades de campo.

\section{Estímulo para a realização de uma atividade de campo}

Predominava como elemento motivador o fato de uma atividade de campo ser um facilitador do processo de ensino e aprendizagem, fator indicado pelos professores $\mathrm{P} 2$, $\mathrm{P} 4, \mathrm{P} 5$ e $\mathrm{P} 6$.

Eu acho que a aprendizagem é efetiva mesmo... A gente percebe que não tem aquela coisa meio que decorada... Eles aprenderam... (P2)

Por mais que você faça, você não vai transmitir a realidade para o aluno se você não levar... (P4)

Porque eles guardam mais fácil as coisas. Você falar é uma coisa... Você levar para ver é diferente. (P5)

... uma visita dessa recompensa quase um bimestre de aulas pra você dar. (...) A aula de campo é uma maneira de eu passar tudo o que eu quero pra eles. (...) Fica muito mais fácil deles aprenderem. (P6)

A motivação mediante o contato dos alunos com o ambiente natural, em uma atividade que foge à rotina escolar, surgiu nas falas dos professores $\mathrm{P} 1$, P2 e P5 como estímulo para realizarem atividades de campo.

Eu acho que esses tipos de visitas são válidos porque você motiva o aluno. (P1) Eu sinto que eles ficam empolgados, todos gostam... (P

A complementação de conteúdos que pode ocorrer a partir dessas atividades apareceu na fala dos professores P1, P2 e P3.

Então, surgem perguntas novas que não surgiram na sala de aula. (...) Eu acho que isso é válido também pra complementar o assunto que você tá tratando. (P1) 
A gente dá toda a teoria em sala de aula, a explicação e tudo mais, e depois a gente leva pra conhecer, pro aluno interagir... (P2)

Complementa... complementa, não! Vou dizer que interage com o que é dado em sala de aula. (P3)

O professor P7 tinha como motivação principal para realizar uma atividade de campo o fato de esta proporcionar o contato com o ambiente natural, permitindo despertar nos alunos sensações (de afeto, interesse ou desinteresse) pelo meio que visitavam. Segundo ele, isso poderia contribuir na decisão dos alunos em seguir ou não, no futuro, uma carreira ligada às Ciências da Natureza e que exigisse, em sua prática, o contato direto com o ambiente natural.

Em síntese, tem-se o seguinte quadro:

Quadro 4 - Estímulo para a realização da visita.

\begin{tabular}{|c|l|}
\hline PROFESSOR & \multicolumn{1}{|c|}{ ELEMENTO MOTIVADOR } \\
\hline P2 - P4 - P5 - P6 & $\begin{array}{l}\text { A atividade constituir um facilitador } \\
\text { do processo de ensino e aprendizagem. }\end{array}$ \\
\hline P1 - P2 - P5 & Motivação dos estudantes. \\
\hline P1 - P2 - P3 & Possibilidade de complementar conteúdos. \\
\hline P7 & $\begin{array}{l}\text { Proporcionar contato com ambiente natural para despertar sensações (boas } \\
\text { ou ruins) em relação ao meio. }\end{array}$ \\
\hline
\end{tabular}

\section{Entraves para a realização de atividades de campo}

Diversos entraves à realização das atividades de campo foram apontados pelos professores. As principais dificuldades foram sintetizadas no Quadro 5.

Quadro 5 - Entraves à realização de atividades de campo.

\begin{tabular}{|c|l|}
\hline PROFESSOR & \multicolumn{1}{c|}{ ENTRAVE } \\
\hline P1 - P3 & Indisciplina dos alunos. \\
\hline P2 - P7 & Custo elevado. \\
\hline P2 - P3 & Carência de tempo (alunos e professores). \\
\hline P5 & Responsabilidade excessiva. \\
\hline P4-P5 & Falta de apoio dos colegas e/ou direção. \\
\hline P3 & Entraves burocráticos. \\
\hline
\end{tabular}


A carência de tempo para preparo da atividade de campo talvez seja um dos mais fortes problemas levantado pelos professores, que limitava ou até impossibilitava a realização de atividades extraclasse. Para que uma atividade de campo seja devidamente aproveitada, deve ter uma boa preparação, desde a escolha do local - que deve ser de conhecimento prévio do professor -, a organização do transporte, entre outras etapas já mencionadas anteriormente. No caso da visita oferecida pelo CDCC/USP, utiliza-se mais de um período (manhã e parte da tarde) para a realização de todo o roteiro, o que impossibilitaria alguns alunos de participar da atividade, como discutiu P2. Naturalmente, o professor pode oferecer alternativas para que esses alunos trabalhem os temas abordados durante a visita, mas certamente nada substituirá o contato direto com o ambiente.

A ausência de professor substituto para suprir as aulas nas demais salas em que o professor atua, sobretudo em escolas estaduais, parece constituir também um sério entrave à realização de atividades de campo. Muitas vezes, os próprios docentes que estão na escola recusam-se a ministrar aulas em salas nas quais não são professores, e o sistema organizacional também não permite substituições. Nesse sentido, os professores P4 e P5 salientaram a ausência de apoio dos colegas. Segundo eles, muitos associam as atividades de campo a passeios que o professor estaria fazendo para deixar de dar aulas. Isso é bastante desanimador, ao considerar-se que uma atividade de campo bem preparada e explorada exige muito do professor - em tempo, dedicação etc.

A indisciplina surge como fator que também inibe o professor de sair da sala com os alunos. Na maioria das vezes, apenas um professor acompanha a turma. Para classes indisciplinadas em sala de aula, é temeroso para o professor levar esses alunos para um ambiente aberto, onde o controle da classe ficaria ainda mais difícil. Embora o comportamento possa ser diferente, graças à novidade representada pela atividade, é fator preocupante. Além disso, o número elevado de alunos por sala dificulta o controle, como ressaltou P1. Além disso, a responsabilidade que o professor tem de assumir com relação aos alunos ao sair da escola também pesa desfavoravelmente.

No caso específico da visita oferecida pelo CDCC/USP, o ônibus é fornecido gratuitamente para as escolas públicas ou que comprovem não ter fins lucrativos. Entretanto, esse serviço é oferecido somente para escolas do próprio município. $\mathrm{O}$ custo elevado do transporte aparece, então, como outro fator limitante para a realização das visitas, como apontou P7. 


\section{Considerações finais}

Os professores que participaram da pesquisa enfatizaram a importância das atividades de campo como estratégia de ensino, embora a exploração ainda ocorresse de maneira limitada. De modo geral, a visita oferecida pelo CDCC/USP era utilizada para complementação e/ou ilustração de conteúdos conceituais abordados em sala de aula. Além disso, em geral, somente o professor explorava a atividade, de forma isolada, sem interação com os demais docentes. Por mais que se fale em interdisciplinaridade, parece mesmo que ainda é escasso o diálogo entre as áreas. E por isso, quem sabe, as atividades de campo não apareceram, na fala desses professores, associadas a programas de EA.

Além disso, apesar de realizarem com certa assiduidade a visita, apontaram entraves burocráticos, financeiros, carência de tempo para preparo e o preconceito de outros educadores para com aqueles que recorrem a atividades dessa natureza, entre outros problemas. Esses fatores podem sinalizar a razão de ter-se um grupo tão pequeno de professores como usuários frequentes da atividade, constituído por profissionais com vários anos de atuação no magistério.

Para superação dessa realidade, acredita-se que a formação inicial e continuada de professores possa colaborar na preparação docente para a adequada inserção de uma pluralidade de estratégias de ensino na prática pedagógica, incluindo as atividades de campo. Entretanto, mais que diversificar estratégias, é preciso trabalhar no sentido de explorá-las em toda sua potencialidade, proporcionando uma formação crítica que permita ao professor ter autonomia e iniciativa para superar entraves, procurando articular toda a equipe escolar, o que poderá favorecer também o desenvolvimento de programas de EA a partir das atividades de campo voltados à transformação da realidade.

\section{Referências bibliográficas}

AMARAL, I. A. Educação ambiental e ensino de ciências: uma história de controvérsias. Pro-Posições, Campinas, v.12, n.1, pp.73-93, mar. 2001.

BALZAN, N. C. Estudo do meio. In: CASTRO, A. D. et al. Didática para a escola de primeiro e segundo graus. 9. ed. São Paulo: Pioneira, pp.111-128, 1987. 
BOGDAN, R. C.; BIKLEN, S. K. Investigação qualitativa em educação: uma introdução à teoria e aos métodos. Portugal: Porto Editora, 1994. (Coleção Ciências da Educação).

BUENO, A. de P. La construcción del conocimiento científico y los contenidos de ciencias. In: ALEIXANDRE, M. P. J. (Coord.) Enseñar ciencias. Barcelona: Editorial GRAÓ, pp.33-54, 2003.

CARBONELL, J. A aventura de inovar: a mudança na escola. Porto Alegre: Artmed, 2002. (Coleção Inovação Pedagógica)

CARVALHO, I. C. M. Em direção ao mundo da vida: interdisciplinaridade e educação ambiental. Brasília: IPE - Instituto de Pesquisas Ecológicas, 1998. (Cadernos de Educação Ambiental)

Qual educação ambiental? Elementos para um debate sobre educação ambiental e extensão rural. Agroecologia e Desenvolvimento Rural Sustentável, Porto Alegre, v.2, n.2, 2001.

CARVALHO, L. M. A temática ambiental e a escola do 1ํo grau. São Paulo, 1989. 286 f. Tese (Doutorado em Educação) - Faculdade de Educação, Universidade de São Paulo, 1989.

DE FRUTOS, J. A. et al. Sendas ecológicas: un recurso didáctico para el conocimiento del entorno. Madrid: Editorial CCS, 1996.

FERNANDES, J. A. B. Você vê essa adaptação? A aula de campo em ciências entre o retórico e o empírico. São Paulo, 2007. 326p. Tese (Doutorado em Educação) Faculdade de Educação, Universidade de São Paulo, São Paulo, 2007.

LEFF, E. Saber Ambiental: sustentabilidade, racionalidade, complexidade, poder. Petrópolis: Vozes, 2001.

LOPES, G. C. L. R.; ALLAIN, L. R. Lançando um olhar crítico sobre as saídas de campo em biologia através do relato de uma experiência. In: ENCONTRO PERSPECTIVAS DO ENSINO DE BIOLOGIA, 8, 2002, São Paulo. Anais... São Paulo: FEUSP/USP, 2002. 1 CD-ROM.

LOUREIRO, C. F. B. Trajetória e fundamentos da educação ambiental. São Paulo: Cortez, 2004.

MINAYO, M. C. S. O desafio do conhecimento: pesquisa qualitativa em saúde. 7. ed. São Paulo: Hucitec; Rio de Janeiro: Abrasco, 2000. (Saúde em debate; 46)

PEGORARO, J. L. Atividades educativas ao ar livre: um quadro a partir de escolas públicas da região de Campinas e dos usos de área úmida urbana com avifauna conspícua (Minipantanal de Paulínia - SP). São Carlos, 2003. 307p. Tese (Doutorado em Ciências da Engenharia Ambiental) - Escola de Engenharia de São Carlos, Universidade de São Paulo, São Carlos, 2003.

SANMARTÍ, N. Didáctica de las ciencias en la educación secundaria obligatoria. Madrid: Sintesis Educación, 2002.

SANTOS, S. A. M.; VIVEIRO, A. A.; SILVA, I. G. A excursão como recurso didático no ensino de biologia e educação ambiental. In: ENCONTRO PERS- 
PECTIVAS DO ENSINO DE BIOLOGIA, 8, 2002, São Paulo. Anais... São Paulo: FEUSP/USP, 2002.1 CD-ROM.

SANTOS, V. M. N.; COMPIANI, M. Formação de professores: desenvolvimento de projetos escolares de educação ambiental com o uso integrado de recursos de sensoriamento remoto e trabalhos de campo para o estudo do meio ambiente e exercício da cidadania. In: ENCONTRO NACIONAL DE PESQUISA EM EDUCAÇÃO EM CIÊNCIAS, 5., 2005, Bauru. Anais... Bauru: ABRAPEC, 2005. 1 CD-ROM.

TRIVIÑOS, A. N. S. Introdução à pesquisa em ciências sociais: a pesquisa qualitativa em educação. São Paulo: Atlas, 1987.

TUNDISI, J. G.; SCHIEL, D. A bacia hidrográfica como laboratório experimental para o ensino de ciências, geografia e educação ambiental. In: SCHIEL, D. et al. (Org.). O estudo de bacias hidrográficas: uma estratégia para educação ambiental. 2. ed. São Carlos: RiMa, pp.3-8, 2003. 


\section{3 \\ FORMAÇÃO INICIAL DE PROFESSORES DE QUÍMICA: FORMAÇÃO ESPECÍFICA E PEDAGÓGICA}

Camila Silveira da Silva ${ }^{1}$ Luiz Antonio Andrade de Oliveira ${ }^{2}$

\section{As licenciaturas em Química}

O objetivo dos cursos de Licenciatura em Química é formar o professor para atuar na educação básica. Tal formação deve contemplar inúmeros aspectos inerentes à formação do bom professor, tais como conhecimento do conteúdo a ser ensinado, conhecimento curricular, conhecimento pedagógico sobre a disciplina escolar Química, conhecimentos sobre a construção do conhecimento científico, especificidades sobre o ensino e a aprendizagem da ciência Química, dentre outros. Nesse panorama, é necessário que os cursos de formação inicial e os professores formadores "promovam novas práticas e novos instrumentos de formação, como estudos de caso e práticas, estágios de longa duração, memória profissional, análise reflexiva, problematizações etc." (Almeida; Biajone, 2007, p.293).

Ao egressar das instituições de Ensino Superior, dos cursos de Licenciatura em Química, o licenciado deve ter o perfil de um profissional com "formação generalista, mas sólida e abrangente em conteúdos dos diversos campos da Química, preparação adequada à aplicação pedagógica do conhecimento e experiências de Química e de áreas afins, na atuação profis-

1 Doutoranda do Programa de Pós-Graduação em Educação para a Ciência da Faculdade de Ciências, campus de Bauru, Universidade Estadual Paulista Júlio de Mesquita Filho (Unesp).

2 Docente do Departamento de Química Geral e Inorgânica, campus de Araraquara, Universidade Estadual Paulista Júlio de Mesquita Filho (Unesp). 
sional como educador nos ensinos Fundamental e Médio" (Zucco et al., 1999, p.458). Entretanto, o que as pesquisas sobre formação inicial de professores de Química apontam é que o cenário encontrado é um tanto quanto diferente. Ao ingressar nas salas de aulas, os professores novatos deparamse com fatos que não lhes foram apresentados ao longo de seu curso de formação inicial e que advêm da prática profissional, situações complexas que ocasionam o surgimento de conflitos (Bejarano; Carvalho, 2003) e exigem uma postura firme e reflexiva do professor, para que possa agir em seu contexto de trabalho de maneira a compreendê-lo e alterá-lo.

Assim, críticas em relação aos cursos de Licenciatura de Química giram em torno de sua validade e eficiência na formação de professores. O perfil profissional esperado de um licenciado em Química parece, em muitos casos, não ser alcançado. Também é possível apontar o descaso com a formação de professores e a desvalorização da profissão dentro das próprias instituições formadoras.

As questões a serem enfrentadas na formação de professores são complexas e históricas:

No caso da formação nos cursos de licenciatura, em seus moldes tradicionais, a ênfase está contida na formação nos conteúdos da área, onde o bacharelado surge como a opção natural que possibilitaria, como apêndice, também, o diploma de licenciado. Neste sentido, nos cursos existentes, é a atuação do físico, do historiador, do biólogo, por exemplo, que ganha importância, sendo que a atuação destes como "licenciados" torna-se residual e é vista, dentro dos muros da universidade, como "inferior", em meio à complexidade dos conteúdos da "área", passando muito mais como atividade "vocacional" ou que permitiria grande dose de improviso e autoformulação do "jeito de dar aula" (Brasil, 2002a, p.13).

Assim, no caso das Licenciaturas em Química, o que ganha importância é a formação do químico e não do professor de Química ou educador químico.

Com a questão da inseparabilidade de conteúdo, forma e método, relaciona-se estreitamente o problema da desarticulação entre os cursos de graduação para os bacharelados e para as licenciaturas. Às licenciaturas se tem reservado o último lugar na universidade, que as considera incapacitadas de produzirem o próprio saber, mero ensino profissionalizante no sentido da preparação para a execução de tarefas por outrem pensadas, versões empobrecidas dos bacha- 
relados e com algum recheio didático-operatório apenas, como se educar não exigisse um saber próprio, rigoroso e consistente (Marques, 2003, p.172).

Diante dos problemas apontados fica a constatação de que é necessária a revisão do processo de formação de professores. Os problemas a serem enfrentados no campo institucional e curricular são inúmeros, dentre eles é possível destacar, no campo institucional: i) segmentação da formação dos professores e descontinuidade na formação dos alunos da educação básica; ii) submissão da proposta pedagógica à organização institucional; iii) isolamento das escolas de formação; iv) distanciamento entre as instituições de formação de professores e os sistemas de ensino da educação básica. No campo curricular, destacam-se: i) desconsideração do repertório de conhecimento dos professores em formação; ii) tratamento inadequado dos conteúdos; iii) falta de oportunidades para desenvolvimento cultural; iv) tratamento restrito da atuação profissional; v) concepção restrita de prática; vi) inadequação do tratamento da pesquisa; vii) ausência de conteúdos relativos às tecnologias da informação e das comunicações; viii) desconsideração das especificidades próprias dos níveis e/ou modalidades de ensino em que são atendidos os alunos da educação básica; ix) desconsideração das especificidades próprias das etapas da educação básica e das áreas do conhecimento que compõem o quadro curricular na educação básica (Brasil, 2002a, p.13-22).

Compreendemos que a formação do professor é um processo contínuo e que não se inicia, e muito menos se finda, em um curso de graduação, tal como as licenciaturas. Mas acreditamos que os cursos de Licenciatura podem proporcionar ações formativas de grande relevância para a formação do profissional professor.

Formar um professor de Química exige que, ao final do curso de graduação, o licenciado garanta bom conhecimento sobre Química e sobre como se ensinar Química, o que envolve muitos aspectos, pois para se ensinar algo de modo significativo é preciso transitar muito bem pela área da Química e pela área de Ensino de Química ${ }^{3}$. Acontece que muitos cursos de licencia-

3 Consideramos a área de Ensino de Química um campo de conhecimento da Química, assim como é a Inorgânica, a Físico-Química, a Orgânica e demais. Mas para facilitar o entendimento, a partir da leitura, referiremo-nos à área de Química, considerando a parte técnica apenas, e a área de Ensino de Química, considerando a interface entre a parte técnica e humana, como a compreensão da construção do conhecimento químico, os aspectos epistemológicos, educacionais e culturais. 
tura em Química acabam por privilegiar apenas um dos lados, geralmente o lado da Química, buscando garantir que o licenciado, egresso do curso de graduação de Licenciatura em Química, possua grande embasamento teórico e prático no campo da Química, conhecimento esse que, em alguns casos, também pode ser bastante questionável.

Sabemos que o campo de atuação, no mercado de trabalho, de um licenciado em Química é bem vasto, devido ao fato de suas atribuições profissionais atenderem às exigências desse mercado, tanto quanto aquelas de quem possui formação de bacharel em Química. Isso contribui para que indivíduos busquem um curso de Licenciatura em Química por pretenderem futuramente atuar em indústrias, empresas, laboratórios, e como na maior parte dos casos, esses cursos são ofertados pelas universidades no período noturno, com relação candidato-vaga nos exames vestibulares relativamente menor que os cursos de bacharelado, é comum encontrar esse tipo de graduando nos cursos de Licenciatura. O ingresso no curso é mais acessível, e as oportunidades são as mesmas que possuem os bacharéis. Os objetivos, perspectivas profissionais, dos indivíduos que buscam os cursos de Licenciatura em Química são os mais diversos, e na minoria dos casos visam à atuação em aulas da educação básica, como professores de Química.

Se pararmos para analisar como são as aulas dos conteúdos específicos, isso é, as aulas de Físico-Química, Orgânica, Analítica, Inorgânica, Bioquímica, em algumas universidades (com a sensação de ser a maioria!), notaremos um grande enfoque na racionalidade técnica. Parece que os docentes da universidade se esquecem de que estão formando (ao menos teoricamente, no papel!) professores de Química para a educação básica, e que estes necessitam de outros fundamentos para que possam atuar nas escolas, durante suas aulas. A articulação entre conhecimento específico (químico) e conhecimento pedagógico parece não ser responsabilidade dos docentes das disciplinas de conteúdo específico. A legislação prevê que "é preciso indicar com clareza para o aluno qual a relação entre o que está aprendendo na licenciatura e o currículo que ensinará no segundo seguimento de ensino fundamental e no ensino médio" (Brasil, 2002a, p.7). Será que os professores formadores estão estabelecendo essas relações? Nossa vivência nos tende a responder que, na maioria dos casos, não! 
Essa questão da articulação entre conhecimento específico e pedagógico também envolve o outro lado da moeda: os professores formadores da área pedagógica que, em algumas instituições, são docentes que não possuem formação em Química, o que também dificulta a aproximação entre conhecimentos químicos e pedagógicos.

Até quando os cursos de Licenciatura em Química terão essas características, não é possível prever. Algumas ações para que esse cenário se modifique já começaram a ser praticadas, com propostas inovadoras para os cursos de Licenciatura em Química (Baptista et al., 2009). Muitos resultados só poderão ser avaliados futuramente.

O fato de termos um parecer do Conselho Nacional de Educação contemplando diretrizes curriculares nacionais para a formação de professores da educação básica, em nível superior, em cursos de licenciatura, de graduação plena (Brasil, 2002a, 2002b), já aponta uma tendência para se pensar e discutir a formação de professores. Um espaço e um tempo para repensarmos como estão estruturados os cursos de Licenciatura e como a formação inicial de muitos professores está se concretizando.

As instituições de nível superior que oferecem cursos de Licenciatura em Química estão se mobilizando para atender às exigências propostas pelo Conselho Nacional de Educação (CNE). Muitos cursos já passaram pelo processo de reestruturação curricular, adequando-se à legislação. Já é um grande passo, mas muito ainda precisa ser feito, pois algumas pesquisas realizadas atualmente sobre os cursos de Licenciatura em Química que implantaram estruturas curriculares renovadas ou que se encontram em fase de reestruturação, de acordo com os pareceres do CNE, apontam ainda os mesmos problemas relacionados à formação de professores, como, por exemplo, a ausência de educadores químicos em boa parte das instituições que oferecem cursos de licenciatura (Francisco Jr et al., 2009), visão positivista da Ciência presente nos projetos pedagógicos (Mesquita; Soares, 2009) e disciplinas de formação pedagógica, somando uma porcentagem relativamente baixa do total de conteúdo científico-cultural em algumas instituições (Kasseboehmer; Ferreira, 2008).

Essas informações apontam a necessidade de avaliações constantes sobre os cursos de Licenciatura em Química oferecidos em nosso país, pois para formar professores, precisamos muito mais do que só reestruturar currículos, é preciso ir além. 


\section{Estudo de caso sobre um curso de Licenciatura em Química}

Uma pesquisa sobre o curso de Licenciatura em Química de uma universidade pública paulista vem sendo desenvolvida desde o ano de 2004, com o objetivo de gerar resultados e reflexões que possam proporcionar melhoras no curso de formação inicial de professores de Química investigado e também contribuir para a área de pesquisa sobre os cursos de formação inicial de professores de Química nas licenciaturas.

Uma das características muito marcantes da instituição a que nos referimos é a grande ênfase na formação de pesquisadores nas áreas tradicionais da Química, deixando a formação de professores em outro plano, e a pesquisa em Ensino de Química, renegada. Isso parece ser comum em outros contextos também:

Nas universidades onde a pesquisa e a pós-graduação na área da química são bem desenvolvidas é menor o interesse dos docentes com a questão da Licenciatura e a formação dos professores. Nessas universidades, o que é mais importante é a formação do cientista que irá alimentar os grupos de pesquisa (Vianna et al., 1997).

As reflexões e os dados que apresentaremos neste texto referem-se a um estudo realizado com alunos formandos do curso de Licenciatura. Serão enfatizadas as questões que dizem respeito à formação pedagógica e à formação específica em Química.

O curso em questão conta atualmente com duas estruturas curriculares, uma vigente a partir de 2006, que se adéqua ao pareceres do Conselho Nacional de Educação para os cursos de formação de professores em licenciaturas; e outra que é válida para os alunos que ingressaram na instituição antes de 2006.

Os formandos que contribuíram com essa pesquisa se formaram na estrutura curricular antiga, que apresentamos no Quadro 1. Trata-se, nesse caso, de um curso com carga-horária total de 2.850 horas-aula, somando 190 créditos.

A estrutura curricular vigente a partir de 2006 passou a ter uma carga horária total de 3.150 horas-aula (210 créditos). 
Quadro 1 - Estrutura Curricular do curso de Licenciatura em Química contendo seriação ideal, nomes e créditos das disciplinas.

\begin{tabular}{|c|c|}
\hline \multicolumn{2}{|c|}{ ESTRUTURA CURRICULAR } \\
\hline \multicolumn{2}{|c|}{$1^{\circ} \mathrm{ANO}$} \\
\hline $1^{\circ}$ Semestre & $2^{\circ}$ Semestre \\
\hline Cálculo Diferencial e Integral I (04) & Cálculo Diferencial e Integral II (06) \\
\hline Introdução à Informática (04) & Física Geral I (04) \\
\hline Introdução ao Estudo da Química (04) & Química Geral Experimental II (04) \\
\hline Química Geral Experimental I(04) & Química Geral II (04) \\
\hline \multicolumn{2}{|l|}{ Química Geral I (04) } \\
\hline \multicolumn{2}{|c|}{ 2o ANO } \\
\hline $3^{\circ}$ Semestre & $4^{\circ}$ Semestre \\
\hline Fundamentos da Educação (04) & Elementos de Geologia e Mineralogia (04) \\
\hline Física Geral II (04) & Física Geral III (04) \\
\hline Química Analítica Qualitativa (08) & Química Analítica Quantitativa (08) \\
\hline Química Inorgânica Básica (04) & História e Filosofia da Ciência (04) \\
\hline \multicolumn{2}{|c|}{ 3응 } \\
\hline 5o-Semestre & 6o-Semestre \\
\hline $\begin{array}{l}\text { Estrutura e Funcionamento do Ensino } \\
\text { Fundamental e Médio (06) }\end{array}$ & Físico-Química II (08) \\
\hline Físico-Química I (04) & Psicologia da Educação (06) \\
\hline Química Orgânica I (06) & Química Orgânica II (06) \\
\hline \multicolumn{2}{|l|}{ Física Geral IV (04) } \\
\hline \multicolumn{2}{|c|}{ 4o $\mathrm{ANO}$} \\
\hline 7o Semestre & 8o-Semestre \\
\hline Didática (06) & Análise Instrumental (06) \\
\hline Físico-Química III (06) & Prática de Ensino I (04) - Teoria \\
\hline Introdução à Química Quântica (02) & Química Inorgânica I (04) \\
\hline Química Orgânica Experimental (06) & Química Orgânica III (04) \\
\hline \multicolumn{2}{|c|}{ 5o ANO } \\
\hline 9o- Semestre & $10^{\circ}$ Semestre \\
\hline Prática de Ensino II (01) Teoria & $\begin{array}{l}\text { Prática de Ensino II (04) Anual - Estágio } \\
\text { Supervisionado em Química }\end{array}$ \\
\hline $\begin{array}{l}\text { Prática de Ensino II (07) Estágio } \\
\text { Supervisionado em Química }\end{array}$ & $\begin{array}{l}\text { Prática de Ensino II (02) - Estágio } \\
\text { Supervisionado em Física }\end{array}$ \\
\hline Química Inorgânica II (04) & $\begin{array}{l}\text { Prática de Ensino II (02) - Estágio } \\
\text { Supervisionado em Matemática }\end{array}$ \\
\hline \multirow[t]{2}{*}{ Introdução à Biologia (04) } & Fundamentos de Bioquímica (06) \\
\hline & Disciplinas optativas (04) \\
\hline
\end{tabular}


Até o presente momento, foram investigadas três turmas de formandos que aqui nos reportaremos a elas como Turma A, Turma B e Turma C. Sempre que apresentarmos respostas dos licenciandos, identificá-lo-emos como licenciando 1, licenciando 2 e assim por diante, junto com a referência de qual turma esse indivíduo se inclui, turma A, turma B ou turma C. Assim, os excertos de respostas virão acompanhados de identificações do tipo L1A, que quer dizer que esse licenciando recebeu o código de número 1 e pertence à turma de formandos $\mathrm{A}$.

Participaram da pesquisa, 25 licenciandos formandos da turma A, 14 formandos da turma B e 22 formandos da turma C.

Os dados a que faremos referência foram obtidos a partir de questionários aplicados no primeiro semestre letivo do último ano de curso de cada turma. As questões eram dissertativas, e as respostas foram analisadas com base na metodologia de Análise de Conteúdo (Bardin, 1977; Franco, 2005), com categorias criadas posteriormente à leitura dos dados.

As questões solicitavam que os licenciandos em Química destacassem i) aspectos positivos e negativos da formação específica e ii) aspectos positivos e negativos da formação pedagógica.

\section{A formação específica}

Apresentamos agora a opinião dos licenciandos sobre a formação específica, ou seja, sobre a formação em Química, recebida ao longo do curso.

As respostas encontradas apontam uma tendência de opiniões entre os formandos das três turmas, tanto para os aspectos positivos quanto para os negativos, sobre a formação em Química.

O que se pôde observar é que a maior parte dos aspectos positivos destacados pelas respostas se concentra na ampla área de atuação que o aluno formado nesse curso obtém como possibilidade em relação ao mercado de trabalho, o que pode ser explicado pelo fato de os licenciados egressos desta instituição possuírem as mesmas atribuições dos bacharéis em Química, de acordo com o Conselho Regional de Química (CRQ) - 4를 Região ${ }^{4}$, e de, ao longo do curso de graduação, poder desempenhar atividades que contemplem essas diversas áreas de atuação: ensino, pesquisa e indústria. Outros 
aspectos ressaltados foram os sólidos conhecimentos na área de Química, boa estrutura da instituição, contato com pesquisadores por meio da iniciação científica, participação em projetos de extensão e desenvolvimento de habilidades e competências individuais. Todos esses fatores foram considerados importantes pelos licenciandos por contribuírem para a formação específica.

A extensão universitária da instituição de Ensino Superior à qual nos referimos neste trabalho é um fator diferencial para a formação profissional e pessoal dos graduandos em questão, já que permite que eles desenvolvam competências e habilidades requeridas para a formação de um bom profissional, sendo que muitos creditam à extensão influência positiva e essencial à sua formação acadêmica e de suas expectativas profissionais futuras.

O grande número de bolsas de extensão universitária e de iniciação científica, disponíveis aos alunos desta instituição, permite que muitos graduandos que teriam a necessidade de trabalhar para manter-se no curso dediquem-se a atividades de extensão e/ou pesquisa, recebendo auxílio financeiro a partir de bolsas. Sendo assim, há um maior aproveitamento de tudo que a universidade oferece, bem como melhor rendimento acadêmico e diminuição da evasão. Isto se deve à alta qualificação do corpo docente e excelência dos projetos desenvolvidos, sua relevância e mérito social.

Desse modo, as opiniões e reflexões dos licenciandos sobre os aspectos positivos de sua formação específica se resumem em cinco grandes categorias:

1. Mercado de trabalho. Categoria em que foram agrupadas as respostas dos licenciandos que referiram que o aspecto positivo de sua formação específica se deve ao fato de propiciar ampla área de atuação no mercado de trabalho: ensino, pesquisa e indústria. Algumas respostas exemplificam essa categoria: " a vantagem do curso de licenciatura é que o aluno sai com atribuições para dar aula ao mesmo tempo que pode trabalhar em laboratório" (L9A) e "oportunidade de fazer pesquisa e também a ampla variedade de subáreas que é possivel trabalhar" (L2B).

2. Formação e professores. Nessa categoria, os formandos atribuíram como aspecto positivo a sólida formação em conceitos científicos e elogiaram muitos professores com quem tiveram aulas, associandoos aos aspectos positivos de sua formação em Química. Isso pode ser verificado em respostas do tipo "formação excelente, com excelentes professores "(L13B) e "sólida formação em química básica, orgânica e analítica” (L4C). 
3. Infraestrutura da instituição. Categoria na qual estão as respostas dos licenciandos que associaram a sua formação em Química à infraestrutura da instituição, como qualidade e quantidade do acervo de livros e estrutura física dos laboratórios, como exemplificado nas respostas: "boa estrutura da biblioteca e laboratórios" (L18A); "boa estrutura da universidade, principalmente nas áreas tecnológicas" (L7B) e "espaço físico muito bom" (L1C).

4. Atividades de extensão e pesquisa. Nessa categoria, os licenciandos atribuíram à participação em atividades de extensão universitária e de iniciação científica os aspectos positivos de sua formação em Química. A experiência em laboratórios, na organização de eventos científicos e o contato com diferentes linhas de pesquisa acadêmica contribuíram de modo positivo para a formação específica desses licenciandos.

5. Habilidades e competências. As respostas dessa categoria indicam que os aspectos positivos da formação específica estão associados ao desenvolvimento de habilidades e competências, como sugerem algumas respostas, tais como: "minha capacidade de raciocínio aumentou muito com o curso" (L3A); "consigo resolver problemas" (L20A) e "ser capaz de explicar fatos” (L5C).

Em relação aos aspectos negativos referentes à formação específica, notamos que ao mesmo tempo em que alguns aspectos foram classificados como positivos para alguns, para outros foram classificados como negativos. Nesse tópico, os professores lideraram a lista dos aspectos negativos. Muitos licenciandos atribuíram a seus professores da universidade o aspecto negativo de sua formação em Química, alegando falta de didática, falta de comprometimento com os alunos, descaso com as aulas, prejudicando assim, segundo os formandos, a formação em Química. A maior queixa dos formandos justifica-se pelo fato dos professores se preocuparem mais com suas pesquisas que com as aulas. Isso pode ser atribuído ao fato de que:

Existe um sentimento de "baixa estima" entre muitos professores universitários para exercer a função docente. A grande parte dos professores que atuam nos cursos de graduação não tem formação didática. Muitos são professores que aprenderam com seus mestres, no sentido de que a escolha da profissão baseou-se na busca da carreira de pesquisador e não na de docente (Barros Filho; Silva, 2005, p.47). 
Encontramos também que a estrutura curricular é o outro aspecto categorizado como negativo na formação em Química, tendo destaque a pouca quantidade de estágios e articulações com outras áreas do conhecimento.

Nos relatos dos formandos existe também como aspecto negativo a infraestrutura disponível durante o período noturno (funcionamento do "xérox", biblioteca, seção de graduação), a estrutura dos laboratórios didáticos, a falta de tempo de trabalhar todos os conteúdos e falha no ensino de conceitos. Quanto a estes dois últimos problemas destacados pelos licenciandos, são necessárias reflexões mais profundas, visto que o domínio do conteúdo específico é de fundamental importância para o exercício da profissão, como ressaltam Carvalho e Gil-Pérez (2001).

Se existe um ponto em que há consenso absolutamente geral entre os professores - quando se propõe a questão do que nós, professores de Ciências, devemos "saber" e "saber fazer" - é, sem dúvida, a importância concedida a um bom conhecimento da matéria a ser ensinada (Carvalho; Gil-Pérez, 2001, p.20).

Sobre estas questões, Rosa (2004) também se manifesta:

Há muito tempo discute-se nos processos de inovação curricular a necessidade de superação da dicotomia bacharelado/licenciatura na formação científica. Nesta discussão, cabe a necessidade de se entender que ser professor de Ciências/Química/Física/Biologia requer um conhecimento aprofundado daquilo que se ensina. (...) o conhecimento profundo das áreas e dos princípios que sustentam a ciência que se ensina habilita o professor no trânsito livre das ideias em sala de aula, garante-lhe autonomia na construção do currículo e lhe permite contextualizar seu ensino, sem se tornar refém de livros didáticos e/ou apostilas empobrecidos de conteúdo científico (Rosa, 2004, p.169).

Nos relatos de alguns formandos, nota-se também que alguns consideram ter dificuldades de entendimento em relação aos conceitos químicos. Segundo Perrenoud (1999) "um sentimento de fracasso, de impotência, de desconforto desencadeia uma reflexão espontânea para todo ser humano e também para o profissional" (Perrenoud, 1999, p.10). Reflexões como essas e as demais que apareceram e aparecerão nesse texto indicam a importância de se trabalhar nos cursos de formação inicial de formação na perspectiva da formação do profissional reflexivo (Maldaner, 2003). 


\section{A formação pedagógica}

Sobre a formação pedagógica, encontramos que os professores estão sempre presentes em quaisquer das reflexões dos licenciandos em Química; eles aparecerem contribuindo tanto positivamente quanto negativamente. $\mathrm{E}$ aqui cabe então valorizar a importante contribuição desse profissional, na formação desses licenciandos. O papel do professor formador merece muito destaque, pois ele é responsável por nutrir esperanças, por encorajar sonhos e por mediar todo o processo de formação.

Nos relatos dos licenciandos também é possível encontrar as contribuições pessoais e profissionais oriundas a partir de sua formação pedagógica e que por isso são destacadas como aspectos positivos em relação à formação pedagógica. O convívio com pessoas de outras áreas, o exercício do lado humano e da cidadania e as experiências de vida, o desenvolvimento de habilidades e competências pessoais e profissionais, tais como falar em público, desinibição, interagir com outras pessoas, quando os formandos mencionam que a partir do contato com a área pedagógica perceberam evolução dessas habilidades e competências. Outras respostas referem-se especificamente à prática pedagógica como o aprendizado de trabalhar em sala de aula, preparar aulas.

No caso do curso de Licenciatura em Química em questão neste trabalho, a distribuição das disciplinas ao longo da estrutura curricular e a carga horária constituem um aspecto positivo, como colocado pelos formandos. Isso possibilita aos licenciandos o contato direto com a parte pedagógica, sem rompimento ou sem que seja deixado para o final do curso, como ocorria nas licenciaturas nos moldes antigos.

Na formação pedagógica, os aspectos negativos destacam a má preparação dos professores das disciplinas pedagógicas para atuarem no Ensino de Ciências Naturais e a falta de ênfase na formação de professores. Apenas um dos professores formadores, das disciplinas pedagógicas, possui formação básica em Química, e a falta de professores com essa formação, segundo os formandos, obstacularizou o aprendizado dos licenciandos, devido à dificuldade de comunicação e orientações mais específicas no desenvolvimento de atividades na área de Ensino de Química. Também é destacada a forma com que são desenvolvidas as aulas.

Encontram-se também nas respostas a falta de trabalho de conclusão de curso, falta de incentivo à leitura extracurricular (além da bibliografia básica do curso) e desenvolvimento de temas atuais. 
Outro problema ressaltado pelos formandos é a desarticulação entre os conteúdos específicos e pedagógicos. Parece não haver um objetivo comum entre os professores que ministram as disciplinas, e esse aspecto parece ser consenso em diversos cursos de licenciatura e um dos que mais favorecem a má-formação dos professores de Química. É como se tratasse de aspectos bem distintos, a parte pedagógica nada tem a ver com a parte específica, e vice-versa. Essa desarticulação gerará problemas na atividade do docente quando o licenciando iniciar sua atuação em salas de aulas, pois essa falta de articulação entre o conteúdo ensinado e a prática efetiva levará o professor novato a fazer a ponte entre estes, o que resulta em uma "didática de sobrevivência” em sala de aula (Longuini; Nardi, 2004, p.196).

Os aspectos negativos da formação pedagógica apontam que a formação de professores não é valorizada, segundo as respostas dos formandos, que colocaram esse aspecto como o mais negativo. Sobre essa questão, recorremos às palavras de Carvalho e Gil-Pérez (2001), que afirmam que "no que se refere aos cursos cobre conteúdos científicos, trata-se dos mesmos cursos-padrão que a universidade proporciona aos demais estudantes" (p.68) e que "a formação científica necessária a um futuro professor não difere, por exemplo, da de um futuro profissional de uma indústria” (p.69). Pelas respostas dos licenciandos, tanto a instituição em si quanto os professores das disciplinas pedagógicas e das disciplinas específicas transmitem aos licenciandos uma desvalorização em relação à profissão professor, desmotivando-os a seguir em tal carreira, não incentivando também o prosseguimento em estudos, em nível de pós-graduação, na área de Ensino de Ciências/Química.

A estrutura curricular também aparece como aspecto negativo, sendo destacada a pouca quantidade de atividades práticas em escolas, como estágios, sendo que esses licenciandos tiveram contato com a escola somente no último ano do curso.

\section{Palavras finais}

Não é possível apresentar aqui todas as ideias expressadas pelos licenciandos em Química que participaram da pesquisa sobre a formação específica e pedagógica que receberam. Mas é possível, a partir do que foi exposto, constatar inúmeros problemas da instituição formadora em relação 
à formação inicial dos professores de Química, tais como a desvalorização da profissão professor, escassez de livros na área de Educação e Ensino de Ciências/Química, desarticulação entre as disciplinas específicas e as pedagógicas caracterizando falta de um objetivo comum, não oferecimento de disciplinas optativas na área de Ensino de Ciências/Química, formação continuada dos professores formadores, tanto das disciplinas específicas quanto das pedagógicas, desenvolvimento das disciplinas pedagógicas e de conhecimento específico, ausência de trabalho de conclusão de curso, ausência de linhas de pesquisa na área de Ensino de Química, dentre outros.

Quanto à estrutura curricular, as mudanças já foram feitas pela instituição, mas avaliações são e serão sempre necessárias.

A ideia não é criticar o curso e muito menos a instituição, mas sim contribuir com informações que apontem os aspectos que precisam ser alterados ou aprimorados. Os aspectos positivos foram apontados, tanto para a formação específica quanto para a pedagógica, e eles também devem ser ressaltados também.

\section{Referências bibliográficas}

ALMEIDA, P. C. A.; BIAJONE, J. Saberes docentes e formação inicial de professores: implicações e desafios para as propostas de formação. Educação e Pesquisa, São Paulo, v.33, n.2, pp.281-295, maio/ago. 2007.

BAPTISTA, J. A. et al. Formação de Professores de Química na Universidade de Brasília: Construção de uma Proposta de Inovação Curricular. Química Nova na Escola, v.31, n.2, pp.140-149, maio 2009.

BARDIN, L. Análise de conteúdo. Lisboa: Edições 70, 1977.

BARROS FILHO, J.; SILVA, D. Análise da opinião de futuros professores a respeito dos processos de ensino e avaliação da aprendizagem nos cursos de licenciatura. Revista Brasileira de Pesquisa em Educação em Ciências, v.5, n.2, p.45-60, maio/ago. 2005.

BEJARANO, N. R. R.; CARVALHO, A. M. P. Tornando-se professor de ciências: crenças e conflitos. Ciência e Educação, v.9, n.1, pp.1-15, 2003.

BRASIL (2002a). Resolução CNE/CP 01. Brasília,DF: Diário Oficial da União. Disponível em: <http://portal.mec.gov.br/cne/ arquivos/pdf/rcp01_02. pdf>. Acesso em: 29 jul. 2009.

BRASIL (2002b). Resolução CNE/CP 02. Brasília,DF: Diário Oficial da União. Disponível em: <http://portal.mec.gov.br/cne/arquivos/pdf /CP022002. pdf>. Acesso em: 29 jul. 2009. 
CARVALHO, A. M. P. ; GIL-PÉREZ, D. Formação de professores de ciências. 5. ed. São Paulo: Cortez, 2001. (Coleção questões da nossa época, v.26)

FRANCISCO JUNIOR, W. E., PETERNELE, W. S.; YAMASHITA, M. A Formação de Professores de Química no Estado de Rondônia: Necessidades e Apontamentos. Química Nova na Escola, v.31, n.2, pp.113-122, maio 2009.

FRANCO, M. L. P. B. Análise de conteúdo. Brasília: Líber Livro Editora, 2. ed. 2005, 79p.

KASSEBOEHMER, A. C.; FERREIRA, L. H. O espaço da prática de ensino e do estágio curricular nos cursos de formação de professores de Química das IES públicas paulistas. Química Nova, v.31, n.3, pp.694-699, 2008.

MALDANER, O. A. A formação inicial e continuada de professores de Química: professores/pesquisadores. 2. ed., Ijuí: Unijuí, 2003, 424p. (Coleção Educação em Química).

MARQUES, M. O. Formação do profissional da educação. 4. ed. Ijuí: Unijuí, 2003, 236p.

MESQUITA, N. A. S; SOARES, M. H. F. B. Relações entre Concepções Epistemológicas e Perfil Profissional Presentes em Projetos Pedagógicos de Cursos de Licenciatura em Química do Estado de Goiás. Química Nova na Escola, v.31, n.2, pp.123-131, maio 2009.

LONGUINI, M. D.; NARDI, R. A prática reflexiva na formação inicial de professores de Física: análise de uma experiência. In: NARDI, R.; BASTOS, F.; DINIZ, R. E. S. (Orgs.). Pesquisas em ensino de ciências: contribuições para a formação de professores. 5. ed., São Paulo: Escrituras, pp.195-211, 2004.

PERRENOUD, F. Formar professores em contextos sociais em mudança: prática reflexiva e participação crítica. Revista Brasileira de Educação. n.12, pp.5-21, 1999.

ROSA, M. I. P. Investigação e ensino: articulações e possibilidades na formação de professores de Ciências. Ijuí: Ed. Unijuí, 2004, 184 p. (Coleção Educação em Química)

VIANNA, J. F.; AYDOS, M. C. R.; SIQUEIRA, O. S. Curso noturno de licenciatura em Química - uma década de experiência na UFMS. Química Nova. 20 (2), pp.213-218, 1997.

ZUCCO, C.; PESSINI, F. B. T.; ANDRADE, J. B. Diretrizes curriculares para os cursos de Química. Química Nova, v.22, n.3, pp.454-461, 1999. 



\title{
4 \\ Ensino de CiênCIas e Educação Moral: IMPLICAÇÕES MÚTUAS
}

\author{
Júlio César Castilho Razera ${ }^{1}$ \\ Roberto Nardi ${ }^{2}$
}

\begin{abstract}
"Tais implicações vão desde os problemas escaldantes e controvertidos do aborto, eutanásia e pena de morte, por exemplo, aos que decorrem do progresso cientifico e tecnológico, como os da clonagem de seres humanos ou da observação de embriões, para referir apenas alguns casos. A suposição é que o estudo do desenvolvimento moral pode ajudar-nos a ver tais questões de um modo mais informado e científico e, em consequência, a advogar decisões mais esclarecidas e morais.” (Lourenço, 2002, p.15)
\end{abstract}

\section{Introdução}

Há muitas questões abertas à investigação na área do ensino de Ciências. Algumas delas referem-se à Educação Moral, cuja ausência de pesquisas cria lacunas que podem conter relevantes contribuições. Como nestas, por exemplo: que princípios ou bases teóricas da Educação Moral podem ser identificados no ensino de Ciências? Quais prevalecem? Por quê?? Que contribuições o ensino de Ciências vem trazendo (ou poderia trazer) para a Educação Moral dos alunos, notadamente em relação ao seu processo de desenvolvimento? Que potencialidades formativas mútuas são encontradas na interface das duas áreas de conhecimento (ensino de Ciências e Educação Moral)?

1 Docente do Departamento de Ciências Biológicas, campus de Jequié, Universidade Estadual do Sudoeste da Bahia (UESB).

2 Docente do Departamento de Educação e do Programa de Pós-Graduação em Educação para a Ciência, Faculdade de Ciências, campus de Bauru, Universidade Estadual Paulista Júlio de Mesquita Filho (Unesp). 
Os temas a envolver moral são controversos e complexos, mas essas dificuldades não impedem suas pesquisas. Especificamente neste trabalho, que versa sobre o ensino de Ciências, a intenção é inserir na discussão, no âmbito da racionalidade, um dos aspectos da moral como objeto de estudo 3 . Então, vejamos.

A moral não se constitui completamente de natureza inata (Piaget, 1994). Portanto, ela é aprendida ao longo da vida, em todos os ambientes sociais. A escola inclui-se entre os ambientes de aprendizagem moral. A Educação Moral escolar é obrigatoriamente implementada em todas as salas de aula, seja de forma explícita ou implícita, intencional ou involuntária, a envolver direta ou indiretamente todos, mas de modo especial os alunos. É uma Educação Moral que pode ter vieses diversos, assim como os seus objetivos (sejam intencionais ou não), mas cujas consequências, certamente, se fazem sentir no processo formativo.

De todos os componentes curriculares, há algumas peculiaridades no ensino de Ciências em relação à Educação Moral que poderiam ser utilizadas em prol do estudante, mas que ainda permanecem ausentes das aulas. Lemke (2006, p.7) é um dos autores que criticam essa característica de indolência, dizendo que o ensino de Ciências "não enfatiza a criatividade, as preocupações morais, o desenvolvimento histórico e o impacto social”. Um dos caminhos apontados pelo autor refere-se à necessidade de ensinar Ciências em uma relação mais próxima com os aspectos morais.

Concordamos que o ensino de Ciências expõe aspectos formativos de moralidade, com características próprias, que merecem nossa atenção. Ao mesmo tempo em que o ensino de Ciências, por causa de seus conteúdos, especialmente no caso dos assuntos controvertidos, torna-se palco privilegiado em relação à moral (nas controvérsias emergem conhecimentos e posicionamentos diversos), é uma disciplina que trabalha com o conhecimento científico e envolve a visão de ciência, sobre os quais a literatura da área vem há tempos debatendo. Dito de outra forma, o ensino de Ciências tem um problema duplo. Por um lado, trabalha com um tipo de conhecimento diferenciado dos demais, cuja compreensão decorre de mudanças paradigmáticas (construções/reconstruções) na forma de pensar dos alunos. Por

3 Utilizamos as palavras de Vázquez (2005, p.23) para ressaltar que "não existe uma moral científica, mas existe - ou pode existir - um conhecimento da moral que pode ser científico. Aqui, como nas outras ciências, o científico baseia-se no método, na abordagem do objeto". 
outro lado, tais mudanças (ou tentativas) são trabalhadas com a presença obrigatória da Educação Moral, cujas características de ocorrência, repetimos, são intencionais ou involuntárias e com consequências diversas ao processo formativo do aluno.

Logo no início do texto, destacamos alguns exemplos de questionamentos abertos à pesquisa. Ao nos referirmos às contribuições que o ensino de Ciências vem trazendo (ou poderia trazer) para o processo de desenvolvimento do aluno, e sobre as potencialidades formativas encontradas na interface entre ensino de Ciências e Educação Moral, encontramos em nossos estudos atuais algumas perspectivas que nos estimulam a algumas reflexões. Embasados por teorias sociomorais, podemos inferir que um ensino de Ciências mais crítico e desmistificado potencializa a promoção do desenvolvimento moral, e vice-versa, isto é, os princípios da Educação Moral como desenvolvimento também são subsídios para o ensino de Ciências na perspectiva da desmistificação da visão de ciência e construção crítica do conhecimento.

Neste trabalho teórico, compartilhamos com o leitor nossos argumentos em prol das possibilidades, que ainda são subestimadas pela área, de subsídios mútuos entre ensino de Ciências e Educação Moral. A nossa expectativa é que as discussões tragam contribuições para o trabalho do professor de Ciências em sala de aula, em uma perspectiva de educação científica e moral baseada no processo de construção da autonomia do aluno, como demonstraremos a seguir.

\title{
Origem e abrangência do problema: o exemplo de um caso
}

\author{
"Há uma diferença entre 'tolerar' que você não tenha as mesmas \\ conviçcóes que eu - sejam religiosas, politicas ou outras - e 'acolher' \\ suas convicções. Porque acolher significa que eu recebo na qualidade de \\ alguém como eu." (Yves de La Taille, apud Cortella; \\ La Taille, 2005, p.11)
}

O relato ${ }^{4}$ a seguir serve para exemplificar o problema e a abrangência que o tema a ser discutido implica, e que, certamente, não se constitui em situação que podemos classificar como simples, isolada e sem relevância.

4 Situação real ocorrida com um dos autores deste trabalho. 
“Em novembro de 1994, com sete anos de experiência no magistério, como sempre fazia porque assim eu tinha aprendido na licenciatura, entrei numa classe de 2 a série do ensino médio e 'naturalmente' pus em prática o desenvolvimento dos conteúdos planejados sobre o tema Evolução para aproximadamente 30 alunos. Ao final da aula, quando todos já saíam para o intervalo, um dos alunos aproximou-se de mim e disse: 'Professor, muito interessante tudo isso que o senhor falou na aula de hoje, mas eu não acredito em nada disso que a ciência diz'. Nesse dia e nos subsequentes conversamos sobre a temática. Nas conversas eu sempre fiz a defesa da ciência, na tentativa de despersuadi-lo. Alguns meses depois, aquele mesmo aluno entregou-me de presente um livro (Figura 1) com a seguinte dedicatória: 'Primeiramente gostaria de agradecer-lhe o companheirismo e a amizade que tivemos. E espero que pela leitura deste livro o senhor possa perceber como a palavra de Deus - a Bíblia - se harmoniza com a ciência, sendo proveitoso para ensinar' (Aluno I. S. M., 22/11/94).
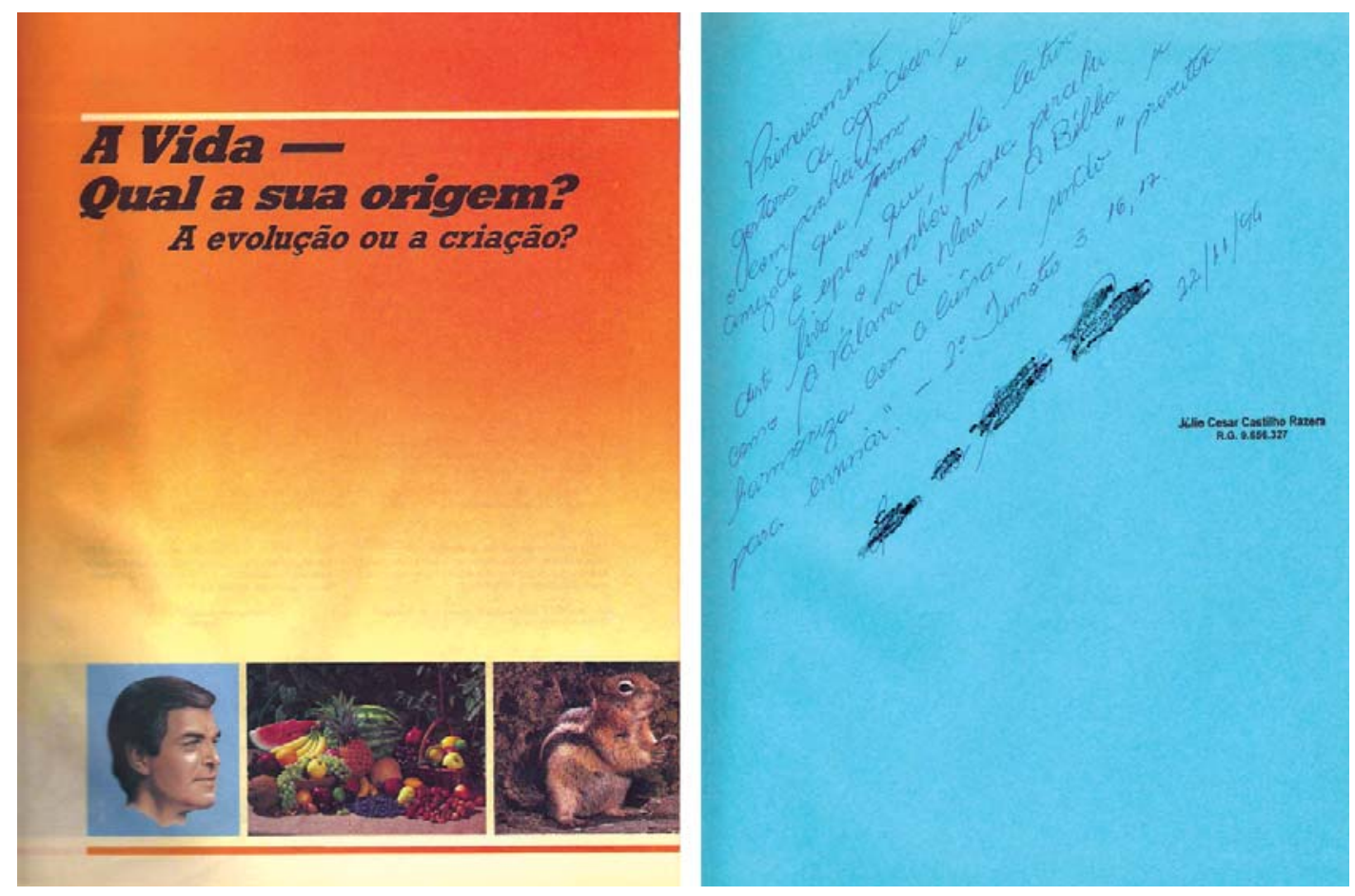

Figura 1 - Capa do livro e dedicatória ${ }^{5}$

5 Livro intitulado A vida - qual a sua origem?: a evolução ou a criação?, editado por Watch Tower Bible Society of Pennsylvania (Nova York), em 1985. Nome do aluno intencionalmente omitido. 
Não, não deixei de ser evolucionista para acreditar no criacionismo e nem me deixei convencer pelas contra-argumentações do aluno, pois bases epistemológicas sustentam minhas ideias sobre o tema. No entanto, após esse evento comecei a refletir sobre o lado coercitivo que eu involuntariamente exercia ao ensinar Ciências, especialmente nas aulas de temáticas controvertidas, com possibilidades de interferência na educação moral dos alunos, pois os meus procedimentos nessas aulas eram inconscientemente coercitivos, no âmbito daquilo que Piaget, extraído de Kant, denomina de heteronomia moral. Comecei a rever mentalmente minhas aulas sobre os muitos assuntos controvertidos da área e lá estava eu ensinando uma incontestável ciência para crianças e adolescentes em processo de formação integral, sem levar em consideração as implicações morais subjacentes. Afinal, para mim bastava apenas e tão somente ensinar os conceitos científicos nas aulas de Ciências, sem me preocupar com os efeitos morais sobre nos alunos."

\section{Desenvolvimento moral e ética do discurso: bases teóricas}

Extraímos nossos argumentos de teorias que nos parecem consistentes para o ensino de Ciências no âmbito da Educação Moral, ainda que não exaustivas ou exclusivas, mas com bases construtivistas e propostas de emancipação subjacentes a objetivos democráticos de educação formal.

Entre os diferentes referenciais teóricos que tratam de educação moral, encontramos respaldo para nossas pretensões na trajetória que se inicia em Kant e passa por Piaget, Kohlberg e Habermas, em pontos de aproximação entre eles, nos elementos e/ou princípios que trazem (vide Freitag, 1989, 1992). A justificativa sobre essa opção recai na presença de elementos e/ou princípios teóricos que subsidiam uma perspectiva educacional voltada para os processos de autonomia moral e de emancipação do indivíduo, cujas bases têm lastros na laicidade e racionalidade.

Temos a ideia clara de que o ensino de Ciências pode se constituir em prol da Educação Moral à luz das teorias que perpassam Kant, Piaget, Kohlberg e Habermas e vice-versa. Nesse caso, a Educação Moral como desenvolvimento - busca de autonomia - pode ser uma teoria orientadora para 
o ensino de Ciências, em trajetória que potencializa a aprendizagem mais crítica e próxima do entendimento da ciência.

As teorias de Piaget (1994) e Kohlberg (1992) sobre o desenvolvimento moral admitem que seja possível estimular cognitivamente os indivíduos para que atinjam um estágio mais alto do raciocínio moral, ultrapassando aquele no qual se encontram ${ }^{6}$. Para ambos, a educação formal tem papel relevante no desenvolvimento moral ${ }^{7}$. A passagem da heteronomia para a autonomia moral ou a evolução para um estágio superior não é naturalmente inevitável, ou seja, os indivíduos podem falhar em alcançar os níveis ou estádios superiores do raciocínio moral. Nesse caso, o fim do educador que busca o desenvolvimento não é a aceleração do desenvolvimento, mas alcançar no processo de crescimento dos alunos os estágios superiores. E mais do que isso, é "evitar o retardamento ou o atraso dos estágios” em relação à faixa etária (Kohlberg; Mayer, 1984, p.94). Então, para a educação escolar contribuir no processo de desenvolvimento moral, resumidamente, pode-se mencionar o trabalho de colaboração e de mediação do professor, no lugar do individualismo e da autoridade unilateral ou da imposição, ou seja, a presença da cooperação, do respeito e do estímulo à consciência dos princípios universais de justiça (dimensão da autonomia moral) no lugar de qualquer tipo de coerção ou coação (dimensão da heteronomia moral).

Lawrence Kohlberg, psicólogo americano que deu sequência às pesquisas de Piaget, sustenta que há maior facilidade de desenvolvimento moral quando a intervenção educativa envolve a exposição ao próximo estágio mais alto daquele que o aluno se encontra, criando-se um grau de conflito ou discrepância que se constituirá em uma experiência efetiva para a mudança. A criação desse conflito requer a aplicação ativa do nível de pensamento que possui o aluno a situações problemáticas, controvertidas. Para Kohlberg (1992), isso implica: i) atenção ao atual estágio de pensamento

6 Para ambos, o raciocínio moral evolui em estágios universais e invariantes. Basicamente, Piaget apresenta os estágios de anomia, heteronomia e autonomia. Os estágios de Kohlberg também passam pela mesma sequência, mas são divididos de forma mais precisa em seis estágios (vide Piaget, 1994 e Kohlberg, 1992).

7 Esses dois conceitos, extraídos de Kant, referem-se à forma de obediência às normas ou regras estabelecidas. Assim, heteronomia moral é a obediência motivada por controle externo, geralmente por interesse egocêntrico (por exemplo, medo de castigo), enquanto autonomia moral é a obediência motivada por controle interno, na escolha consciente de um princípio aceito como válido, mas mutável se for justo (por exemplo, em prol da vida) e cuja responsabilidade social vem acompanhada por essa consciência na escolha. 
da criança; ii) fazer corresponder o estímulo com o estágio, por exemplo, exposição a modos de raciocínio próprios de um estágio acima do atual da criança; iii) fazer surgir entre as crianças um conflito genuíno e de desacordo em relação a situações problemáticas (diferente da educação tradicional transmissiva de "respostas certas" ou "boas condutas"); iv) expor as crianças a estímulos sobre os quais podem ser ativos, nos quais a resposta às situações-estímulo esteja associada com um feedback natural.

Habermas (1987a, 1987b, 1999, 2003) também se ocupou de estudos sobre a moral. Em suas preocupações aparecem os valores éticos que, equivocadamente, se reduziram à técnica, excluindo-se assim a decisão por intermédio do diálogo. A racionalidade instrumental, ao desviar-se de seu específico caminho, isolou o indivíduo nas formas de pensar e agir. Habermas quer resgatar o espaço da racionalidade comunicativa na esfera de decisão, porque suas convicções são de que as ideias de verdade, liberdade e justiça estão inseridas nas estruturas do discurso.

As bases do agir comunicativo referem-se às pretensões de validade e não de poder. Os pós-estruturalistas, por exemplo, não diferenciam validade e poder. Habermas, sim. Para ele, pode-se pretender que algo seja bom ou verdadeiro impondo a força ou entrando em um diálogo no qual os argumentos dos outros podem mudar sua opinião. No primeiro caso, há uma pretensão de poder; no segundo, uma pretensão de validade. Quando vencem as pretensões de poder, aplica-se o argumento da força. Quando se abrem às pretensões de validade, impõe-se a força dos argumentos (Flecha; Gómez; Puigvert, 2001).

$\mathrm{Na}$ Teoria da Ação Comunicativa, Habermas coloca a argumentação no lugar da ação teleológica. Por meio da linguagem, busca-se o consenso de uma forma livre de toda coação externa e interna. Nesse caso, a base de toda interação é o entendimento mútuo pela argumentação e simetria de participação.

Quem participa convictamente numa argumentação tem necessariamente de partir do princípio de que a situação comunicativa é, em princípio, garantia dum acesso público, de iguais direitos de participação, autenticidade dos participantes, ausência de coaç̧ão na tomada de posições, etc. Os intervenientes só se conseguem persuadir reciprocamente, se partirem do pressuposto pragmático de que o seu sim e não se deixam determinar em exclusivo pelo imperativo do melhor argumento (Habermas, 1999, p.131). 
Por fim, cabe aqui um breve comentário sobre o distanciamento que tomam as ideias de Piaget, Kohlberg e Habermas em relação às propostas de Educação Moral como socialização, de Émile Durkheim, que segundo nossa maneira de pensar ainda influencia significativamente a educação escolar, incluindo o ensino de Ciências. Na proposta de Durkheim (2000, 2002), apesar de também fundada em critérios racionais e leigos, a competência do julgamento moral é anulada no sujeito, pois a sociedade é absoluta e julga o que é certo e o que é errado. A questão pedagógica, nesse caso, tem o foco na promoção da obediência às regras e no ajuste e adaptação do sujeito à sociedade, tendo-se como base os seguintes elementos de moralidade: espírito de disciplina, adesão ao grupo social e autonomia (aqui entendida como submissão às regras sociais e aceitação da coerção do grupo; diferente da ideia de Piaget, em que o sujeito se emancipa da coerção do grupo).

\section{O conhecimento científico e o ensino: o que a autonomia moral tem a ver com isso?}

Há diferentes linhas que procuram explicar a natureza do método científico. Essas linhas não são coincidentes, mas, apesar das divergências, como nos dizem Alves-Mazzotti e Gewandsznajder (2004), podemos vislumbrar alguns princípios metodológicos mais gerais que têm aceitação da maioria dos filósofos de ciência contemporâneos. Ambos os autores citam, por exemplo, a ideia consensual (excetuando-se os relativistas extremados) de que "o método científico é uma atividade crítica. Consequentemente, o desenvolvimento de um espírito crítico é importante para a compreensão e para a prática da atividade científica” (p.63). Portanto, a crítica tem vínculos não somente com o fazer Ciência, mas também com a compreensão sobre esse fazer, ou seja, não pode estar ausente do ensino e da aprendizagem sobre Ciência.

Uma das características da atividade crítica é "admitir a possibilidade de erro, procurando então evidências para nossos juízos acerca dos fatos" (p.63). Entendemos, assim, que o ensino de Ciências não se reduz à transmissão de nenhum produto acabado, mas deve abrir evidências para os juízos dos alunos, admitindo-se que, mesmo com os erros prévios acerca dos conhecimentos científicos, eles tenham a possibilidade de desenvolver um 
posicionamento crítico, o que não ocorrerá, a nosso ver, na mera transmissão de conteúdos acabados. "A decisão de adotar uma postura crítica, de procurar a verdade (mesmo sem nunca ter a certeza de que ela foi encontrada), e de valorizar a objetividade, é uma decisão livre" (p.64). No entanto, essa liberdade de escolha vem acompanhada de responsabilidades, pois gera consequências para o indivíduo que fez a escolha ou para a comunidade que a acatou (exemplo: misturar em um mesmo nível de conhecimento a Ciência, o senso comum e as pseudociências).

A crítica é justamente o fator de diferenciação da Ciência e, portanto, deve permear os procedimentos de seu ensino. "Se discussões críticas não têm valor, então não há mais diferença entre uma opinião racional - fruto de ponderações, críticas e discussões que levam em conta outros pontos de vista - e um mero preconceito" (p.64).

Não é novidade dizer que há diferentes formas de conhecer o mundo. Juntamente com a Ciência coexistem outras. No entanto, mesmo que cada uma tenha suas características próprias, podemos dizer que "o grau de atitude crítica" faz a diferença. Podemos, nesse caso, transportar para o ensino de Ciências essa perspectiva de atitude crítica da Ciência, que AlvesMazzotti e Gewandsznajder (2004, p.86) apresentam, na qual "consiste em discutir qualquer ideia ou afirmação, buscando erros, contradições internas ou incoerências com outros campos do conhecimento".

Conhecimentos de senso comum também são importantes, úteis, resolvem determinados problemas, são transmitidos a gerações posteriores e também podem ser considerados como um tipo de conhecimento crítico. No entanto, possuem baixo nível crítico e são mais limitados que o conhecimento científico, pois resolvem poucos problemas, não passam por testes rigorosos e controlados, não são discutidos com profundidade e com embasamentos consistentes. Nesse caso, não há motivos para previamente rechaçar ou descartar os demais tipos de conhecimentos que os alunos inevitavelmente trazem para a sala de aula. Se forem previamente descartados, rechaçados ou não utilizados, perde-se a oportunidade de exercitar os graus de criticidade entre o que se apresenta pelos alunos e os conhecimentos científicos. Afinal, se são problemas trazidos pelos alunos, o ensino de Ciências não pode se ausentar de propiciar a eles as ferramentas que perpassam as críticas para a busca de suas respostas. 
É na escola que jovens e adolescentes se apresentam para os conteúdos científicos, para exercitar suas capacidades críticas e para se desenvolver cognitiva e moralmente. No entanto, questiona-se se essa oportunidade é dada, se o ambiente de sala de aula está servindo a esse fim ou não. Afinal, como a Ciência é apresentada aos alunos? Que oportunidades são dadas aos alunos de, por eles próprios, formular e reformular suas ideias sobre os conhecimentos científicos? Que elementos são disponibilizados para o desenvolvimento cognitivo e moral por que passam os estudantes? Os procedimentos e/ou as formas de apresentação dos conhecimentos científicos interferem nesse desenvolvimento? Lembrando que não são cientistas formados, mas pessoas que se apresentam em diferentes fases de desenvolvimento distantes da completude (se é possível dizer que se chega nela).

Um outro aspecto relevante e que podemos inserir nessa discussão refere-se à visão de ciência. De acordo com Lemke (1997, p.139), com frequência a Ciência é tida, de forma intencional ou involuntária, como a "mais verdadeira" ou, ainda, como "a forma verdadeira de falar acerca do mundo", e nas aulas de Ciências, "exceto raras ocasiões, essa é a forma como se ensina e se apresenta a Ciência. Não como uma forma de falar sobre o mundo, mas como a forma que é o mundo". O autor preocupa-se com os aspectos morais envolvidos na forma ou no "como" a Ciência é ensinada em sala de aula e questiona: "Quem se beneficia mais da perspectiva da Ciência como 'verdade objetiva'?".

Ao ensinar o conteúdo do currículo de Ciências e os valores que frequentemente o acompanham, a educação científica, muitas vezes sem notar, também perpetua uma certa "mística da Ciência". Essa mística tende a fazer com que a Ciência apareça ante os alunos como dogmática, autoritária, impessoal e, ainda, inumana. [...] Isso aliena os alunos a respeito da Ciência. [...] Analisar como professores e alunos falam sobre Ciência em aula pode nos ajudar a compreender como se perpetua essa mística, que é nociva, e o que podemos fazer a respeito (Lemke, 1997, p.13, tradução nossa).

Como se vê, a preocupação não pode se restringir apenas ao conteúdo, mas também ao "como" ocorre o ensino de Ciências, isto é, a forma como ensinamos Ciências aos alunos. Nesse caso, entendemos que a forma de ensinar Ciências tem implicações não somente sobre a construção de uma ideia de Ciência nos alunos, mas também sobre os aspectos de formação moral deles. 
Lemke preocupa-se especificamente com a linguagem utilizada em sala de aula, que se constitui em elemento relevante na construção do ideário sobre ciência nos alunos ("aliena os alunos a respeito da Ciência"). Sobre esse aspecto nós concordamos, mas ampliamos a discussão com a inclusão de novos elementos referentes aos aspectos de moralidade - elementos extraídos das teorias por nós elegidas como subsidiárias e/ou confirmadoras/legitimadoras de um ensino de Ciências mais próximo de um projeto de emancipação (livre de tutela ou de algum tipo de coerção externa).

Ainda de acordo com Lemke, a forma ou estilo de comunicação no ensino de Ciências pode reforçar dois conjuntos de crenças sobre a Ciência: a ideologia da verdade objetiva e a ideologia da verdade especial da Ciência. No primeiro caso, de antemão, cria-se uma imagem de que "existem fatos ante os quais simplesmente não se pode contra-argumentar" (p.149) ou de que a ciência produz fatos estabelecidos, permanentes e incontestáveis, isto é, com "uma aura de objetividade total, diante da qual nenhuma afirmação feita por pessoas comuns, em momento e lugar particulares, é capaz de merecer" (p.150). No segundo caso está a oposição entre ciência e senso comum, colocando-se por detrás o perigo de ensinar "de uma maneira muito sutil" que a Ciência é "uma verdade especial, disponível somente para os cientistas e que é extremamente incompreensível para o homem comum" (p.150), ou seja, a Ciência é apresentada como matéria difícil e feita somente por cientistas que, por sua vez, são pessoas de "uma casta especial, que não somente possuem um conhecimento e umas habilidades especiais, mas que possuem talentos especiais e intelectos excepcionais que não têm e nunca terão os alunos" (p.150).

Entre a ciência e o seu ensino na escola básica há alguns aspectos que podemos diretamente associar, mas também existem outros que não comportam tal associação. A educação escolar tem, entre outros, o diferencial de trabalhar com crianças, adolescentes e jovens em outro nível de maturidade, tanto em relação aos conhecimentos como também de outros aspectos (afetivo, biológico, emocional, cultural, moral etc.). Mesmo que a ciência traga como bem resolvidos determinados temas, por exemplo, no ensino de Ciências não podemos esperar a mesma ocorrência de resolução sobre esses mesmos temas, pois crianças, adolescentes e jovens apresentam-se em estágios cujos conhecimentos ainda tendem para o senso comum. 
O problema, então, não se resume simplesmente ao conteúdo de Ciências a ser ensinado. Em todos os casos, e em especial nos assuntos controvertidos, o problema está também em "como trabalhar os conteúdos". O "como" desse processo implica interferências no desenvolvimento moral, à luz das teorias sociomorais que anteriormente destacamos.

A preocupação do ensino de Ciências deve permanecer nos conteúdos e conhecimentos científicos. Não se diz o contrário. No entanto, não em ambiente de reforço à heteronomia moral, pois nele se perde a oportunidade de provocar tanto o desenvolvimento cognitivo como moral, implicando prejuízos à compreensão e/ou construção do conhecimento científico perante os demais tipos e também ao processo de autonomia moral.

Os conhecimentos científicos são resultados de um processo, não são produtos acabados. Por que, então, trabalhar como se fossem produtos acabados nas aulas de Ciências? Por que privar o aluno, por si ou com auxílio e cooperação (base da autonomia moral) dos demais (colegas e professores), de passar por um processo de construção conceitual? Trabalhar só com o que a comunidade científica aceita atualmente é um reforço à ideia de ciência como produto e não como processo, reduzindo-se possibilidades de desenvolvimento da aprendizagem, tanto no âmbito da cognição como da moral.

Em momentos anteriores, brevemente mencionamos as particularidades dos assuntos controvertidos, notadamente no tratamento deles em aula, os alunos, que estão em fase de aprendizagem, em diferentes níveis de cognição e de raciocínio moral, trazem ideias, conceitos e conhecimentos mais voltados para o senso comum, muitas vezes construído com a contribuição dos familiares, amigos, instituições religiosas etc. Na sala de aula, descartar tudo isso?

Não se é ingênuo a ponto de defender que se inicie e se termine com o senso comum em uma aula de Ciências, mas também não se pode querer abreviar um tempo de aprendizagem que pertence somente ao aluno ao finalizar ou dar resultado pronto a aquilo que o aluno vai continuar aprendendo ao longo de sua vida.

Evidentemente que não se imagina o ensino da Astrologia nas aulas de Ciências. Da mesma forma, também não se imagina o ensino do Criacionismo. A evolução deve ser ensinada. Assim também ocorrerá com sexuali- 
dade, células-tronco, alimentos transgênicos, inseminação artificial etc. No entanto, não se pode negar o caráter de controvérsia que envolve esses e outros assuntos e querer tratá-los em ambiente de prejuízos ao desenvolvimento moral dos alunos. Ensinar, sim, mas novamente questiona-se: "como?"

Toda essa situação pode envolver resistências diversas e alguns mal-entendidos em relação à Ciência, frente aos demais conhecimentos, e o que se deve ensinar nas aulas de Ciências. Por isso, enfatizamos que não há aqui defesa contrária ao ensino de conteúdos e conhecimentos de ciência em sala de aula. Não defendemos, por exemplo, que se ensine o senso comum ou os conhecimentos religiosos nas aulas de Ciências, como alguns podem de forma equivocada pensar - isso seria muita ingenuidade de nossa parte. Além disso, se assim pensássemos, incorreríamos no mesmo tipo de equívoco de favorecimento ao elitismo tecnocrático e às dificuldades impostas ao desenvolvimento moral, cuja ruptura ensejamos. Encontramos, no entanto, maiores possibilidades de ensino e aprendizagem de Ciências se levado em conta o processo de desenvolvimento moral dos alunos.

\section{O ensino de Ciências e os ambientes de heteronomia e autonomia moral: uma síntese}

Justapondo-se o ensino de Ciências e a Educação Moral como desenvolvimento, com bases nas discussões feitas até aqui, em síntese, podemos construir dois grupos antagônicos (que chamaremos de ambientes) com alguns de seus respectivos princípios, elementos e estratégias. Em comparação com o ambiente de heteronomia moral, o ambiente de autonomia moral apresenta uma constituição teórico-prática mais favorável: em prol tanto do ponto de vista do desenvolvimento moral, que é base para o processo de emancipação, quanto para a compreensão, análise crítica e construção do conhecimento científico. Vejamos.

a) Ambiente de heteronomia moral: ausência de diálogo e de cooperação; autoritarismo; imposições coercitivas intencionais ou não; transmissão de conteúdos acabados e de uma visão de ciência como produto e não como processo; conhecimentos divergentes do 
científico previamente rechaçados ou ignorados com desdém; uso do conhecimento científico como submissão; uso de argumentos com pretensões de poder no lugar das pretensões de validade; despreocupação com a forma ou estilo de comunicação (transmissão não intencional de reforço acerca de crenças equivocadas sobre a ciência); não criação intencional de debates simetricamente participativos e com objetivos de entendimento; despreocupação com a criação de situações de estímulo que visem aos níveis mais altos de raciocínio moral; estratégias que não contemplam o trabalho coletivo e trocas de ideias.

b) Ambiente de autonomia moral: presença frequente de diálogo e cooperação; ausência de autoritarismo e de imposições coercitivas diversas; discussão de conteúdos sem o reforço das visões equivocadas sobre a ciência; não ignorar ou rechaçar previamente e sem discussão nenhum tipo de conhecimento que se apresente divergente do científico; uso de argumentos com pretensões de validade no lugar de pretensões de poder; preocupação e autorregulação com a forma ou estilo de comunicação (não transmissão de crenças equivocadas sobre a ciência); criação intencional de debates simetricamente participativos e objetivos de entendimento; criação de situações de estímulo que visem aos níveis mais altos de raciocínio moral; estratégias diversas que contemplem o trabalho coletivo com trocas de ideias.

\section{Considerações finais}

"Um docente que não dá valor ao modo como ensina nem ao conteúdo ensinado talvez devesse realizar outro tipo de trabalho."

(Mario Sergio Cortilla, apud Cortella; La Taille, 2005, p.80)

O ensino de Ciências na escola básica não é para formar especialistas, mas para aprendizagens gerais que incluem também o desenvolvimento moral.

Tomando-se por base as teorias da Educação Moral como desenvolvimento, encontramos diferentes e contrárias possibilidades para o ensino de Ciências. Da mesma forma, encontramos no ensino de Ciências as mesmas possibilidades correspondentes para o desenvolvimento moral. 
Se por um lado os aspectos do ambiente heterônomo são obstáculos para a aprendizagem cognitiva e evolução do raciocínio moral, ainda reforçam a visão mística de ciência e de compreensões mais abalizadas sobre os diferentes tipos de conhecimento existentes. Por outro lado, os aspectos do ambiente de autonomia moral, além de se harmonizarem com o ensino desmistificado do conhecimento científico, também ampliam as possibilidades de uma aprendizagem mais consciente e crítica das Ciências. Uma consciência crítica e racional que pode atuar sobre o conhecimento científico, a fim de melhor entendê-lo no seu processo de construção e diferenciá-lo dos demais tipos de conhecimentos, porém sem excluí-los a priori e sem a obrigação de aceitar esse ou aquele por algum tipo de imposição externa (coerção).

Por fim, ressaltamos que o espaço limitado deste artigo nos fez optar por alguns recortes que impediram maiores detalhes ou aprofundamentos sobre o tema. Dessa forma, apresentamos as seguintes informações complementares, a fim de dirimir possíveis dúvidas dos leitores sobre os nossos propósitos: i) distanciamento das ideias apresentadas neste trabalho com algum tipo de relativismo ou liberalismo irrefletido (laissez-faire); ii) ideias não desvinculadas das preocupações com o conteúdo científico; iii) nenhuma proposta de fazer outra defesa que não da racionalidade da Ciência e da relevância dos conhecimentos científicos; iv) defesa de uma Educação Moral em prol do ensino de Ciências baseada em princípios racionais, laicos e de emancipação.

\section{Referências bibliográficas}

ALVES-MAZZOTTI, A. J.; GEWANDSZNAJDER, F. O método nas ciências naturais e sociais: pesquisa quantitativa e qualitativa. São Paulo: Pioneira/ Thomson, 2004.

CORTELLA, M. S.; LA TAILLE, Y. Nos labirintos da moral. Campinas: Papirus, 2005.

DURKHEIM, E. La educación moral. Madrid: Editorial Trotta, 2002.

La enseñanza de la moral en la escuela primária. Reis - Revista Española de Investigaciones Sociológicas, n.90, p.275-287, abr./jun. 2000.

FLECHA, R.; GÓMEZ, J.; PUIGVERT, L. Teoría sociológica contemporánea. Barcelona: Paidós, p.125-160, 2001.

FREITAG, B. A questão da moralidade: da razão prática de Kant à ética discursiva de Habermas. Tempo social-Rev. Sociol. USP, v.1, n.2, p.7-44, 1989. 
Itinerários de Antígona: a questão da moralidade. Campinas: Papirus, 1992. HABERMAS, J. Consciência moral e agir comunicativo. Rio de Janeiro: Tempo Brasileiro, 2003.

Comentários à ética do discurso. Lisboa: Instituto Piaget, 1999.

Teoria de la acción comunicativa I: racionalidad de la acción y racionalización social. Madri: Taurus, 1987a.

Teoria de la acción comunicativa II: crítica de la razón funcionalista. Madri: Taurus, $1987 b$.

KOHLBERG, L. Psicologia del desarrollo moral. Bilbao: Editorial Desclée de Brauwer, 1992.

KOHLBERG, L.; MAYER, R. El desarrollo del educando como finalidad de la educación. Valencia: Vadell Hermanos, 1984.

LEMKE, J. L. Aprender a hablar ciencia: lenguaje, aprendizaje y valores. Barcelona/Buenos Aires/México: Paidós, 1997.

. Investigar para el futuro de la educación científica: nuevas formas de aprender, nuevas formas de vivir. Enseñanza de las Ciencias, v.24, n.1, p.5-12, 2006.

LOURENÇO, O. M. Psicologia de desenvolvimento moral: teoria, dados e implicações. 3. ed., Coimbra: Almedina, 2002.

PIAGET, J. O juízo moral na criança. São Paulo: Summus, 1994.

VÁZQUEZ, A. S. Ética. 27. ed. Rio de Janeiro: Civilização Brasileira, 2005. 


\section{5 \\ UM ESTUDO EXPLORATÓRIO SOBRE O ENSINO DE ASTRONOMIA NA FORMAÇÃO CONTINUADA DE PROFESSORES}

Gustavo Iachel ${ }^{1}$

Roberto Nardi ${ }^{2}$

\section{Introdução}

Antes mesmo de ingressar no Ensino Superior em Licenciatura Plena em Física, já admirava a Astronomia. Durante a graduação, meu gosto por esta Ciência intensificou-se. Em meados de 2005, enquanto realizava o curso de Licenciatura Plena em Física na Universidade Estadual Paulista, em Bauru, conheci e participei do projeto de telescópios refletores ${ }^{3}$. Em 2006, minha atual coorientadora apresentou ao Grupo de Estudos Astronômicos a ideia de implantar em Bauru um Observatório Didático Astronômico e me convidou para participar desse projeto. Após conhecer alguns trabalhos na área de Ensino de Ciências que envolviam a Astronomia, como a dissertação elaborada por Langhi (2004), comecei a refletir sobre o tema. Tudo o que estudei sobre a Astronomia, bem como as atividades de extensão universitária que realizei nesse período de graduação no observatório didático com as escolas da região, fizeram-me perceber aspectos importantes sobre o Ensino de Astronomia na educação básica:

1 Professor-mestre colaborador do Observatório Didático Astronômico "Lionel José Andriatto" e docente do Departamento de Educação e do Programa de Pós-Graduação em Educação para a Ciência Faculdade de Ciências, campus de Bauru, Universidade Estadual Paulista Júlio de Mesquita Filho (Unesp).

2 Docente do Departamento de Educação e do Programa de Pós-Graduação em Educação para a Ciência, Faculdade de Ciências, campus de Bauru, Universidade Estadual Paulista Júlio de Mesquita Filho (Unesp).

3 Projeto: "Construção e Utilização de um aparelho telescópio", processo 194/03-Proex-Fundunesp, cuja coordenação foi realizada pela professora Rosa Maria Fernandes Scalvi. 
i. Praticamente não existe ou apresenta deficiências.

ii. Os professores não conhecem adequadamente os conteúdos da Astronomia que devem ensinar e, quase sempre, apresentam concepções alternativas não condizentes àquelas aceitas como corretas pela Ciência, muitas vezes próximas às de seus próprios alunos.

Entendo que os cursos de formação continuada são necessários por esse motivo e devem ser planejados a partir dessa realidade, e não a partir do senso comum. Essas constatações fizeram-me buscar apoio em referenciais teóricos que julgo pertinentes para a proposta e realização de um curso de formação continuada, objeto deste estudo, os quais são apresentados neste trabalho.

Diante do exposto, o objetivo geral desta pesquisa foi o de investigar quais contribuições um curso de formação continuada voltado ao ensino de Astronomia promoveu no desenvolvimento profissional dos docentes participantes.

Uma das primeiras constatações para a realização do curso foi a necessidade de entender quais são as reais necessidades formativas dos professores quando trabalhamos com a sua formação inicial ou continuada. Para isso, foi necessário o estudo de referenciais teóricos que sustentassem essas discussões. Garcia (1999) e Carvalho e Gil-Perez (2006) serviram como o apoio teórico.

Além disso, a notória falta de preparo dos docentes para o ensino da Astronomia faz com que esses profissionais encontrem dificuldades até mesmo no momento de selecionar fontes confiáveis de conteúdo relacionado à Astronomia. Por essa razão, foram utilizados textos/artigos de divulgação científica de revistas da área de ensino, com o intuito de apresentar aos docentes a possibilidade que eles possuem de poder buscar e utilizar esse recurso durante suas aulas, familiarizando-os com a sua leitura, reconhecendo também que esses trabalhos foram submetidos a periódicos nacionais e avaliados por, no mínimo, dois pesquisadores, que são, geralmente, vinculados de alguma forma ao estudo da Astronomia, seja na área da pesquisa em Educação, seja na área da Astronomia Aplicada ou "pura", o que torna os textos fontes mais confiáveis.

Por isso, julguei importante "levantar" as contribuições realizadas por pesquisadores da área de Ensino de Ciências referente aos conteúdos espe- 
cíficos de Astronomia, publicadas em periódicos nacionais e internacionais desde 1990, que se relacionam com os PCN e a Proposta Curricular do Estado de São Paulo.

Enfim, a partir de consultas realizadas a docentes da educação básica, de filmagem das dinâmicas utilizadas, mais as metodologias empregadas no curso, foi produzida uma dissertação (Iachel, 2009), que entendo ser uma contribuição para a formação continuada de professores da educação básica sobre o ensino da Astronomia.

\section{Formação de professores}

Considerei importante buscar informações sobre a formação inicial e continuada de professores, sem a pretensão de exaurir o tema, tendo em vista que essa área de pesquisa é próspera e diversificada. A leitura dos trabalhos de Garcia (1999) e Carvalho e Gil-Pérez (2006) trouxe-me elementos suficientes para esse exercício.

\section{Os princípios que regem a formação docente}

Quais seriam os princípios que regem a formação de professores? Pensando nessa questão, Garcia (1999, p.26) aponta para oito características fundamentais que, segundo o autor, qualquer curso com esse propósito deveria considerar para a sua estruturação. Seguem abaixo tais características, com nossos comentários:

1. Conceber a formação de professores como um contínuo, sendo que o desenvolvimento profissional é um projeto ao longo da carreira docente, desde a formação inicial.

2. Integrar a formação de professores em processos de mudança, inovação e desenvolvimento curricular.

3. Vincular o processo de formação de professores com o desenvolvimento organizacional da escola, além de salientar que é a formação que adota como problema e referência o contexto próximo dos professores, aquela que tem maiores possibilidades de transformação da escola. 
4. Articular e integrar a formação de professores com os conteúdos propriamente acadêmicos e disciplinares e a formação pedagógica.

5. Integrar teoria e prática na formação de professores.

6. Isomorfismo.

7. Individualização.

8. Adotar uma perspectiva que saliente a importância da indagação e o desenvolvimento do conhecimento a partir do trabalho e reflexão dos próprios professores (Garcia, 1999, p.26).

Pretendo retomar esses princípios durante a análise de dados e a inferência das conclusões para poder observar se foram respeitados durante o curso proposto e ministrado.

\section{As necessidades formativas dos docentes}

Ao definir as "necessidades formativas", Carvalho e Gil-Pérez (2006) utilizam em seu trabalho as expressões "saber" e "saber fazer". Entendendo por "saber" todo o conhecimento acadêmico/específico e didático sobre o conteúdo a ser ensinado. Se o professor pouco sabe sobre a matéria, provavelmente possuirá dificuldades para ensiná-la, o que já é um consenso entre os profissionais da educação, fato que se torna mais evidente durante o ensino de conteúdos relacionados à Astronomia. Isso se deve, talvez, ao baixo número de cursos de Ensino Superior no País que possuem, em sua estrutura, a disciplina Astronomia, seja obrigatória ou opcional.

"Saber" não se trata apenas de entender os pressupostos e fundamentos dos conteúdos curriculares relacionados a uma dada disciplina, é também: conhecer acerca da construção histórica desses conhecimentos disciplinares; o que levou o homem a criar postulados para a resolução de problemas; de que forma os cientistas abordam essas teorias e como elas são validadas e aceitas; como ocorre a interação CTSA, isto é, como relacionar a Ciência com a tecnologia, a sociedade e o ambiente em que vivemos. Além disso, o profissional deve reconhecer que as teorias estão em constante evolução. Deve também saber escolher conteúdos interessantes e acessíveis aos seus alunos, e sempre estar preparado para a formação continuada, para o aprofundamento dos conhecimentos específicos e didáticos, salientando a necessidade do constante aprendizado, devido ao curto período de tempo enquanto estudantes universitários. 
Quando o professor não possui um sólido conhecimento sobre a sua disciplina, as ideias de senso comum que possui sobre as teorias e práticas que a envolvem tornam-se visíveis. Essas ideias devem ser analisadas, "colocadas à luz", para que os professores em formação possam desmistificá-las e corrigi-las, caso se apresentem inconsistentes. O levantamento e análise das concepções sobre Astronomia dos docentes participantes desta pesquisa, bem como de suas falas durante as discussões, apresentadas na dissertação (Iachel, 2009) corroboram essa afirmação.

Tanto quanto o "saber", o "saber fazer" está diretamente relacionado com a prática docente. Em suma, o professor deveria saber preparar atividades e dirigi-las juntamente com seus alunos, evitando problemas de organização durante a aula; conhecer o papel do experimento e da simulação computacional, para que possa utilizar esse rico recurso em prol da aprendizagem de seus alunos; saber avaliar os conhecimentos adquiridos pelos estudantes de forma adequada, buscando compreender que uma "nota baixa" pode representar não somente uma falta de conhecimento do aluno, mas também algum problema durante a prática de ensino relacionada a esses conteúdos; ter o conhecimento e o hábito de associar o seu ensino às constantes pesquisas sobre educação, não somente buscando conhecer as teorias de aprendizagem que a pesquisa didática lhes proporciona, mas também contribuir para sua elaboração.

O "saber" e o "saber fazer" são tidos por Carvalho e Gil-Pérez (2006) como as necessidades formativas dos professores, sobre as quais adiciono um elemento que busquei em Garcia (1999, p.84), o "saber por quê". Trata-se de uma série de conhecimentos justificativos que o docente deve possuir sobre/ para o ensino de qualquer disciplina, isto é, o porquê de ensinar determinados conteúdos e, no caso dos participantes dessa pesquisa, o porquê de se ensinar a Astronomia. Quando o professor conhece quais são os objetivos de aprendizagem dos alunos a serem alcançados em sua aula, isto é, quais competências são almejadas, terá maior facilidade em selecionar os conteúdos e estratégias de ensino. Acredito ter realizado uma breve discussão sobre os conhecimentos justificativos para o ensino da Astronomia durante a introdução deste trabalho.

Enfim, entendo como sendo as necessidades formativas dos professores os conhecimentos que se compõem nesta tríplice de saberes: o "saber", o "saber fazer" e o "saber por quê". 


\section{O curso de formação continuada: a Astronomia e o ensino de Astronomia}

\section{A definição dos conteúdos a serem estudados no curso}

Com base nos PCN, alguns conteúdos relacionados à Astronomia foram escolhidos para compor o curso ministrado.

Tabela 1 - Conteúdos selecionados e ministrados no curso de formação continuada.

\begin{tabular}{l|l}
\hline Conteúdo relacionado à Astronomia. & Presente nos PCN \\
\hline O planeta Terra e suas características. & $3^{\circ}$ ciclo $-5^{\underline{a} \text { e }} 6^{\underline{a}}$ séries \\
\hline O fenômeno de formação das fases da Lua. & $3^{\circ}$ ciclo $-5^{\underline{a} \text { e } 6^{\underline{a}} \text { séries }}$ \\
\hline As estações do ano. & $4^{\circ}$ ciclo $-7^{\mathrm{a}}$ e $8^{\mathrm{a}}$ séries \\
\hline O fenômeno de formação dos eclipses solares e lunares. & $4^{\circ}$ ciclo $-7^{\mathrm{a}}$ e $8^{\mathrm{a}}$ séries \\
\hline O Sistema Solar e seus constituintes. & Ensino Médio \\
\hline Rebaixamento de Plutão da categoria de planeta para planeta anão. & Ensino Médio \\
\hline $\begin{array}{l}\text { Corpos menores do Sistema Solar e o perigo que eles representam } \\
\text { ao planeta Terra (Asteroides, Meteoroides, Meteoros, Meteoritos, } \\
\text { Cometas). }\end{array}$ & Ensino Médio \\
\hline
\end{tabular}

\section{A utilização de textos de divulgação científica como suporte de estudo dos professores participantes}

Durante o curso ministrado, foram utilizados textos de divulgação científica como suporte para o acompanhamento e estudo dos professores sobre os conteúdos relacionados à Astronomia que foram abordados nos encontros. Com base em um levantamento bibliográfico, foram selecionados sete artigos e uma apostila de construção de lunetas, dentre 41 artigos, quatro dissertações e três teses, para compor o Caderno de Textos.

Tabela 2 - Estrutura do Caderno de Textos.

\begin{tabular}{c|c|c|c|c}
\hline Texto & Título & Abordagem & $\begin{array}{c}\text { Relaciona-se } \\
\text { ao PCN }\end{array}$ & Autor(es) \\
\hline 1 & $\begin{array}{c}\text { Ideias de senso comum } \\
\text { em Astronomia. }\end{array}$ & $\begin{array}{c}\text { Concepções } \\
\text { alternativas }\end{array}$ & Todos & LANGHI (2005) \\
\hline 2 & $\begin{array}{c}\text { A Terra e sua posição } \\
\text { no universo: formas, } \\
\text { dimensões e modelos } \\
\text { orbitais. }\end{array}$ & Histórica & $\begin{array}{c}3^{\circ} \text { ciclo } \\
5^{\underline{a}} \text { e 6a séries }\end{array}$ & NEVES (2000c) \\
\hline
\end{tabular}


Tabela 2 - Continuação.

\begin{tabular}{|c|c|c|c|c|}
\hline Texto & Título & Abordagem & $\begin{array}{c}\text { Relaciona-se } \\
\text { ao PCN }\end{array}$ & Autor(es) \\
\hline 3 & $\begin{array}{l}\text { Las fases de la Luna, } \\
\text { ¿Cómo y cuándo } \\
\text { enseñarlas? }\end{array}$ & Teórica & $\begin{array}{c}3 \text { o ciclo } \\
5 \text { 5 e }^{6 \underline{a}} \text { séries }\end{array}$ & KRINER (2004) \\
\hline 4 & $\begin{array}{c}\text { Eclipse Solar Total: } 3 \text { de } \\
\text { novembro de } 1994 .\end{array}$ & Teórica & $\begin{array}{c}4^{\circ} \text { ciclo } \\
7^{\mathrm{a}} \text { e } 8^{\mathrm{a}} \text { séries }\end{array}$ & LIVI (1993) \\
\hline 5 & $\begin{array}{l}\text { De } 9 \text { a } 12 \text { y finalmente } 8: \\
\text { ¿Cuántos planetas hay } \\
\text { alrededor del Sol? }\end{array}$ & $\begin{array}{l}\text { Teórica e } \\
\text { histórica }\end{array}$ & Ensino Médio & $\begin{array}{l}\text { TANCREDI } \\
(2007)\end{array}$ \\
\hline 6 & $\begin{array}{l}\text { O perigo que vem do } \\
\text { espaço. }\end{array}$ & Teórica & Ensino Médio & BEDAQUE (2005) \\
\hline 7 & $\begin{array}{c}\text { Abordando o ensino } \\
\text { de óptica através da } \\
\text { construção de telescópios. }\end{array}$ & Experimental & Ensino Médio & $\begin{array}{c}\text { BERNARDES et al } \\
(2006)\end{array}$ \\
\hline 8 & $\begin{array}{l}\text { Apostila de construção de } \\
\text { lunetas astronômicas. }\end{array}$ & Experimental & Ensino Médio & $\begin{array}{c}\text { Grupo de Estudos } \\
\text { Astronômicos - } \\
\text { Unesp - Bauru. } \\
\text { (2007) }\end{array}$ \\
\hline
\end{tabular}

\section{Aportes teóricos para a constituição e análise dos dados}

\section{A dinâmica de Grupo Focal}

O Grupo Focal é um instrumento de coleta de dados de cunho qualitativo e foi utilizado nesta pesquisa com o objetivo de identificar percepções, atitudes e ideias dos participantes sobre a Astronomia e o seu ensino. Para que as dinâmicas realizadas durante o curso ocorressem de forma satisfatória, busquei nos estudos de Dias (2000) e Galego e Gomes (2005) as principais características e princípios que regem o Grupo Focal.

Existem certos cuidados para a elaboração de um Grupo Focal. Por exemplo, durante o planejamento de cada uma das dinâmicas que apliquei, organizei as guias de entrevistas, cada qual com suas questões e objetivos, conforme sugerido por Dias (2000).

Os roteiros foram utilizados apenas como guias (ou fio condutor), e não como questionários fechados de entrevistas. Por este motivo, as perguntas não foram direcionadas a um ou outro professor, e sim para todo o grupo. Pude atuar como moderador, fomentando a discussão entre os participantes, pois, segundo Galego e Gomes (2005), a principal função do modera- 
dor do Grupo Focal é promover a participação e a interação, controlando dispersões e sobreposições de alguns indivíduos do grupo, além de proporcionar clima favorável à exposição de ideias por todos os participantes.

Durante o curso, três dinâmicas de Grupo Focal foram filmadas. Justifica-se a filmagem no que tange a coleta da maior quantidade de informações durante as discussões, o que é inviável de ser realizado por meio de anotações. A filmagem também supera as coletas obtidas apenas em áudio, pois no vídeo podemos analisar também as expressões dos entrevistados. Após a realização dos Grupos Focais, todas as falas foram transcritas.

\section{A metodologia de análise dos dados recolhidos}

A Análise de Conteúdo trata-se de um conjunto de técnicas que visam principalmente ultrapassar a incerteza, ou seja, investiga se a leitura que realizamos de uma mensagem é a mesma realizada pelas demais pessoas (se é generalizável); busca o enriquecimento da leitura, aumentando sua produtividade e pertinência. Como método de pesquisa, a Análise de Conteúdo é constituída de fases. A primeira, que diz respeito à organização da análise, "corresponde a um período de intuições, mas tem por objetivo tornar operacionais e sistematizar as ideias iniciais, de maneira a conduzir a um esquema preciso do desenvolvimento das operações sucessivas, em um plano de análise". Nessa etapa, o pesquisador escolhe quais os documentos que pretende analisar. No caso desta pesquisa, os documentos submetidos à Análise de Conteúdo foram as respostas dadas nos questionários preenchidos pelos professores e as falas deles nas transcrições das dinâmicas de Grupo Focal. A exploração de todo o material ocorre na forma de leituras flutuantes, ou seja, aquelas nas quais o analista entra em contato com o objeto que será analisado e começa a formular algumas ideias iniciais (Bardin, 2000, p.95).

Após o pesquisador formular hipóteses baseadas na leitura flutuante que realizou dos documentos, é comum que ocorram as manifestações dos indices e indicadores (quantitativos e qualitativos). Durante a análise do questionário sobre as concepções alternativas, foram utilizados indicadores quantitativos. Por exemplo, para a análise das respostas dos professores sobre a constituição do Sistema Solar, um dos índices pode ser a menção da existência das órbitas planetárias ao redor do Sol. O indicador para esse 
exemplo seria uma quantificação do número de professores que citaram esse índice. Já para a análise das transcrições dos Grupos Focais, os índices (dessa vez, qualitativos) são unidades de registro denominadas conteúdos, que correspondem a afirmações sobre um determinado assunto.

Após a primeira fase da análise, quando ocorre a escolha dos documentos e a sua leitura flutuante, bem como a formulação de hipóteses, índices e indicadores, pode ocorrer a etapa de categorização das componentes das mensagens analisadas. A autora afirma que "este processo não é uma etapa obrigatória de toda e qualquer Análise de Conteúdo", mas deixa claro que a "maioria dos procedimentos de análise organiza-se, no entanto, em redor de um processo de categorização". Para esta pesquisa, foram elaboradas categorias para melhor organizar as informações, contribuindo, dessa forma, para a realização das inferências (Bardin, 2000, p.117).

\section{A análise de conteúdo dos dados recolhidos}

Antes da análise dos questionários respondidos e das transcrições das dinâmicas de Grupo Focal, os documentos passaram pela leitura flutuante, sobre a qual foram elaboradas dimensões de análise, cada qual com seus temas internos. As hipóteses e objetivos foram definidos, sendo responsáveis pela constituição dos índices e indicadores.

Devido à quantidade de dados colhidos e analisados, eles não serão apresentados neste trabalho. Caso haja interesse, o leitor poderá vê-los na dissertação que originou este texto (Iachel, 2009).

\section{Considerações finais}

Anteriormente, foram apresentados oito princípios que, segundo Garcia (1999), regem a formação de professores. Tendo em vista a análise de dados realizada neste estudo, posso inferir sobre como esses princípios foram considerados durante o curso de formação continuada ministrado.

1. Conceber a formação de professores como um contínuo: sobre esse aspecto, residem os cursos de formação continuada como o proposto durante esta pesquisa. A necessidade contínua de estudo e preparo, 
ao longo da carreira docente é recomendação explícita das Diretrizes Curriculares Nacionais para a Formação de Professores (Brasil, 2001). Uma iniciativa como a realizada faz com que os docentes reflitam sobre a importância em aprender novos conceitos, tirar dúvidas, atualizar-se e consolidar os conhecimentos específicos e didáticos que possuem, particularmente sobre a Astronomia. Durante o curso, o participante $\mathrm{P}_{5}$ reconhece que as universidades não formam professores preparados para ensinar Astronomia, entendendo que essas instituições não veem esta tarefa como um de seus papéis. Além disso, os licenciandos não têm tempo suficiente, enquanto universitários, de estudar e aprender tudo o que um dia, porventura, venham a ensinar, justificando novamente a importância da formação continuada.

2. Necessidade de integrar e formar professores em processos de mudança, inovação e desenvolvimento curricular: entendo que mudanças ocorram por meio da conscientização. Os participantes ficaram frente a questionamentos sobre a Astronomia e seu ensino, e suas dúvidas e curiosidades tornaram-se evidentes durante o curso. Uma das análises, que trata da mudança de conduta profissional, ilustra o fato. Além disso, para ocorrem mudanças, deve-se reconhecer que existem problemas no cotidiano escolar, como, por exemplo, a quantidade excessiva de aulas por semana, que se traduzem nas dificuldades em ensinar a Astronomia. Também se discutiu sobre a importância das ideias de senso comum trazidas pelos alunos para a sala de aula, que geralmente sofrem interferência da mídia e da internet, que pode se tornar uma ferramenta didática importante quando usada adequadamente. Entendo que foi a primeira oportunidade para alguns dos docentes participantes de discutir sobre esses assuntos, proporcionando-lhes possibilidades de refletir, embasados em pesquisas da área de Ensino de Ciências.

3. A formação deve considerar como problema e referência o contexto próximo do professor: o ensino de Astronomia deve fazer parte do cotidiano do professor, conforme os documentos oficiais, como o PCN (Brasil, 1998, 1999, 2002a, 2002b) e a Proposta Curricular Estadual (São Paulo, 2008a e 2008b). Além disso, o curso buscou investigar e sanar algumas deficiências na formação inicial desses docentes, 
principalmente pela falta sofrida por não terem tido a oportunidade de estudar esses conteúdos quando realizaram a graduação e, por isso, entendo que a atividade de formação continuada aproximou-se dos problemas e do contexto dos docentes participantes. É válido ressaltar que, embora o curso não tenha sido desenhado com a participação dos docentes, foram consideradas as necessidades destes, em termos de concepções espontâneas presentes na literatura, os documentos oficiais etc. Além disso, a procura pelo curso foi espontânea, ou seja, os docentes não foram convocados pela Diretoria de Ensino para participar do curso, fato que demonstra o interesse dos professores pelas atividades propostas.

4. A formação de professores deve articular com os conteúdos propriamente acadêmicos e disciplinares, bem como com a formação pedagógica: entendo que muitos conhecimentos acadêmicos e disciplinares relacionados à Astronomia foram desenvolvidos e estudados durante o curso, como também foram discutidas questões pedagógicas na realização das dinâmicas de Grupo Focal. No entanto, aponto para um equívoco: não foi registrada, em momento algum, uma discussão sobre o "saber por que" ensinar Astronomia. Por isso, entendo que a tríplice "saber", "saber fazer" e "saber por quê" (relacionada ao saber acadêmico, ao saber didático e pedagógico e ao saber justificativo do ensino de um determinado conteúdo) deva ser observada com cuidado quando da proposta de cursos de formação continuada. Ou seja, não bastam os conhecimentos disciplinares específicos, didáticos e pedagógicos sem uma sólida justificativa da razão em se ensinar a Astronomia.

5. Integrar teoria e prática na formação docente: apesar das discussões realizadas durante o curso sobre o ensino da Astronomia, não foi possível averiguar se os professores praticaram seus novos conhecimentos em sala de aula. Mas entendo que os discursos dos professores apontaram para a intenção em praticar o ensino dessa Ciência. $\mathrm{O}$ curso, em si, buscou integrar teoria e prática.

6. Isomorfismo: entendo que cada um dos professores deva adaptar os novos conhecimentos didáticos adquiridos durante esse curso à realidade de sua sala de aula e de sua formação didático-pedagógica que professam neste momento de seu desenvolvimento profissional. 
7. Considerar a formação clínica do professor, respeitando as características e necessidades de cada um: durante a pesquisa constatou-se que a dinâmica de Grupo Focal, além de considerar as ideias de cada indivíduo sobre os assuntos estudados, também ofereceu oportunidade de trocas de expectativas e experiências entre os participantes, ou seja, as dinâmicas fomentaram a participação e a reflexão coletiva.

8. Salientar a indagação e o desenvolvimento do conhecimento a partir do trabalho e reflexão dos próprios professores: esse princípio aproxima-se do sétimo quanto ao cerne das reflexões pessoais de cada docente, o que acredito que resulta na busca pelo conhecimento e pelo contínuo aperfeiçoamento profissional.

Além da observação desses princípios, acreditamos que alguns temas possam ser desenvolvidos durante um curso de formação continuada, além daqueles estudados com base no Caderno de Textos elaborado:

1. Construção de telescópios refratores em oficinas de lunetas: a dinâmica realizada durante o curso despertou o interesse dos professores e de seus alunos. Variadas formas de como utilizar os conhecimentos teóricos (óptica geométrica e fenômenos da luz) e práticos (montagem do equipamento) obtidos durante a oficina foram apresentados pelos participantes.

2. Reconhecimento e observação do céu: alguns professores sugeriram atividades de observação astronômica. Essa atividade pode ser mais organizada e produtiva quando utilizados guias de campo e cartas celestes impressas ou visualizadas em computadores (como, por exemplo, por meio do software gratuito Stellarium).

3. Uso da internet e materiais multimídia: tendo em vista que a internet passou, há algum tempo, a ser uma fonte de consulta dos professores, sugiro uma atividade que possa ser realizada pelos participantes de um curso de formação continuada para o ensino de Astronomia e que consista na busca semanal por materiais multimídia ou sites com conteúdo relacionado a esta Ciência, disponíveis na internet, para que, ao final das atividades, todos possuam e possam compartilhar uma lista de endereços eletrônicos e um banco de imagens, vídeos, documentários, que os auxiliarão a ilustrar os fenômenos astronômicos durante o ensino desses conteúdos. 
Não obstante, entendo que algumas ações possam ser tomadas pelos formadores, quando da realização de cursos desse caráter, para contribuir com a formação continuada dos professores participantes:

1. Elaborar e utilizar um Caderno de Textos de divulgação científica: o Caderno de Textos foi elaborado com o intuito de fornecer materiais para a discussão e acompanhar os professores durante os seus estudos. Os participantes puderam colaborar de forma efetiva nas discussões, pois elaboraram dúvidas e pontos de vista devido à leitura prévia dos artigos selecionados. Entendo que também seja possível que os professores possam participar da estruturação de um Caderno de Textos, sugerindo temáticas ou textos, o que não ocorreu durante o curso ministrado. A dissertação que originou este trabalho apresenta sugestões de textos e pode ser consultada como um "catálogo", auxiliando coordenadores de cursos de Astronomia na localização de artigos para a organização de seu caderno. Além desses fatores, é mais prático que os participantes possuam os textos impressos em mãos do que tê-los em meio digital, como, por exemplo, em mídia de $\mathrm{CD}$, ou mesmo quando enviados por e-mail ou disponibilizados em sites.

2. Enfatizar o trabalho coletivo: os participantes do curso experimental afirmaram sobre a importância de reunir pessoas de formações diferentes para o aprendizado coletivo. Esse fator colabora com a formação continuada desses docentes, pois vivenciam formas variadas de observar e analisar um mesmo fenômeno. A dinâmica de Grupo Focal é uma sugestão de atividade que envolve a participação de todos e contribui para o desenvolvimento da capacidade que os professores possuem de participar de trabalhos colaborativos. Entendo que os Grupos Focais se diferenciem das dinâmicas de discussão em grupo por apresentarem pressupostos metodológicos bem definidos, principalmente no que tange ao papel do moderador. Além disso, as discussões em grupo tendem a ocorrer de forma mais "solta", o que pode acarretar um afastamento das principais questões de pesquisa, o que não acontece em uma dinâmica de Grupo Focal.

3. Considerar as concepções alternativas dos participantes: o processo de apresentar aos professores as concepções alternativas do grupo antes 
das discussões mostrou-se produtivo, pois, desta forma, além de conhecer e discutir sobre suas próprias ideias em relação à Astronomia, eles puderam ser incentivados a:

i. tomar conhecimento de outras pesquisas na área de ensino de Astronomia;

ii. conhecer e poder aplicar entre seus estudantes técnicas de levantamento de concepções alternativas, pois os docentes reconhecem que essas ideias interferem em seu ensino;

iii. comparar as concepções alternativas presentes na literatura com a de seus alunos ou com suas próprias concepções.

Acredito que uma coleta de concepções alternativas antes do início do curso possa contribuir com a coordenação durante o planejamento do curso, indicando quais são as principais dificuldades dos participantes em relação a cada conteúdo.

Não obstante, é válido salientar que questões burocráticas geralmente surgem quando cursos de formação continuada são elaborados. Essas questões podem prejudicar o andamento do curso e, com isso, a formação continuada dos envolvidos, quando não são resolvidas em tempo. Por essa razão, sugiro que os formadores deem a devida atenção aos aspectos burocráticos que envolvem o planejamento de um curso de formação continuada.

Enfatizo que essas características, bem como toda a atividade de formação continuada apresentada, não devam ser aceitas como prontas e acabadas, ou então usadas como uma "receita", mas possam auxiliar na formulação de cursos com esse propósito, sendo sempre necessária a sua adaptação aos interesses e necessidades dos participantes envolvidos.

Na primeira seção, foi exposto o objetivo geral desta pesquisa: investigar quais contribuições um curso de formação continuada voltada ao ensino de Astronomia promoveu no desenvolvimento profissional dos docentes participantes. Algumas dessas contribuições levaram os professores à, principalmente:

- reconhecer dificuldades no ensino de Astronomia, o que compreendo ser o passo inicial em busca de saná-las;

- tomar conhecimento e refletir sobre os conteúdos relacionados à Astronomia presentes nos PCN e na Proposta Curricular Estadual;

- melhorar o sentimento de segurança para o ensino dessa Ciência; 
- refletir e discutir sobre: a formação inicial; como as ideias de senso comum interferem no aprendizado dos estudantes; sugestões do uso da internet e de atividades relacionadas à Astronomia; a construção e o funcionamento dos telescópios refletores.

\section{Referências bibliográficas}

BARDIN, L. Análise de Conteúdo. Portugal: Edições 70, 2000. 225 p.

BEDAQUE, P. O perigo que vem do espaço. Revista Latino-Americana de Educação em Astronomia, n.2, pp.103-111, 2005.

BERNARDES, T. O.; BARBOSA, R. R.; IACHEL, G.; BATAGIN-NETO, A.; PINHEIRO, M. A. L., SCALVI, R. M. F., Abordando o ensino de óptica através da construção de telescópios. Revista Brasileira de Ensino de Física, v.28, n.3, pp.391-396, 2006.

BRASIL. Secretaria de Educação Média e Tecnologia. Parâmetros Curriculares Nacionais: terceiro e quarto ciclos do Ensino Fundamental - Ciências Naturais. Brasília. MEC/SEMTEC. 1998.

Secretaria de Educação Média e Tecnologia. Parâmetros Curriculares Nacionais: Ciências da Natureza, Matemática e suas Tecnologias. Brasília. MEC/ SEMTEC. 1999.

Ministério da Educação. Conselho Nacional de Educação. Diretrizes Curriculares Nacionais para a Formação de Professores da Educação Básica, em nivel superior, curso de licenciatura, de graduação plena. Parecer CNE/CP no 9/2001, pub no DOU de 18/01/2002. Brasília: MEC, 2001. 44 p. Disponível em: <http://www.mec.gov.br>. Acesso em: ago. 2008.

Ministério da Educação. Secretaria de Educação Média e Tecnológica. Parâmetros Curriculares Nacionais: Ensino Médio. Brasília: Ministério da Educação, 2002a.

PCN + Ensino Médio: Orientações educacionais complementares aos Parâmetros Curriculares Nacionais. Ciências humanas e suas tecnologias. Brasília: Ministério da Educação, 2002b.

CARVALHO, A. M. P.; GIL-PÉREZ, D. Formação de professores de ciências. Coleção Questões da nossa Época, n.26, 8. ed., São Paulo: Cortez, 2006.

DIAS, C. A., Grupo Focal: técnica de coleta de dados em pesquisas qualitativas, Informação E Sociedade: Estudos, v.10, n.2, 2000.

GALEGO, C.; GOMES, A. A. Emancipação, ruptura e inovação: o "focus group" como instrumento de investigação. Revista Lusófona de Educação, n.5, 2005.

GARCIA, C. M., Formação de professores - para uma mudança educativa, Portugal: Porto, 1999. 
IACHEL, G. Um estudo exploratório sobre o ensino de Astronomia na formação continuada de professores. 2009. 229 f. Dissertação (Mestrado em Educação para a Ciência). Faculdade de Ciências, Unesp, Bauru, 2009.

KRINER, A. Las fases de la Luna, ¿Cómo y cuándo enseñarlas?, Ciência $\mathcal{E}$ Educação, v.10, n.1, pp.111-120, 2004

LANGHI, R. Um estudo exploratório para a inserção da Astronomia na formação de professores dos anos iniciais do Ensino Fundamental. 2004. $240 \mathrm{f}$. (Mestrado em Educação para a Ciência). Faculdade de Ciências, Unesp, Bauru, 2004.

Ideias de senso comum em Astronomia. In: Laerte Sadre Jr.; Jane Gregorio-Hetem; Raquel Shida. (Orgs.). Observatórios virtuais. São Paulo: Instituto de Astronomia, Geofísica e Ciências - USP, 2005, pp.1-9, CD-ROM.

LEITE, C. Formação do professor de Ciências em Astronomia: uma proposta com enfoque na espacialidade. 274f. Tese. (Doutorado em Educação) - Faculdade de Educação, Universidade de São Paulo, 2006.

LIVI, S. H. B., Eclipse solar total: 3 de novembro de 1994. Caderno Catarinense de Ensino de Física, v.10, n.3, pp.262-268, 1993.

NEVES, M. C. D. A Terra e sua posição no Universo: formas, dimensões e modelos orbitais. Revista Brasileira de Ensino de Física, v.22, n.4, pp.557-567, 2000c.

SÃO PAULO. Secretaria de Estado da Educação. Proposta Curricular do Estado de São Paulo. Ciências: Ensino Fundamental - Ciclo II. São Paulo: SEE, 2008a. Secretaria de Estado da Educação. Proposta Curricular do Estado de São Paulo. Física: Ensino Médio. São Paulo: SEE, 2008b.

TANCREDI, G., De 9 a 12 y finalmente 8: ¿Cuantos planetas hay alrededor del Sol?. Revista Latino-Americana de Educação em Astronomia, n.4, pp.69-77, 2007. 


\title{
6 \\ ANÁLISE DE PRÁTICAS PEDAGÓGICAS REALIZADAS EM ATIVIDADES DE FORMAÇÃO CONTINUADA DE PROFESSORES: A APROXIMAÇÃO DA HISTÓRIA E FILOSOFIA dA CIÊNCIA NO ENSINO DE FísICA
}

\author{
Sandra Regina Teodoro Gatti ${ }^{1}$ \\ Roberto Nardi ${ }^{2}$
}

\section{Introdução}

A pesquisa aqui relatada insere-se em uma linha de investigação do projeto desenvolvido pelo Grupo de Pesquisa em Ensino de Ciências, apoiado pelo CNPq e intitulado: "Práticas Pedagógicas e Processos Formativos de Professores na Área de Ensino de Ciências e Matemática”" cujo objetivo principal é o desenvolvimento de investigações articuladas que gerem um conjunto de subsídios para a reflexão sobre os processos de formação docente na área de Ensino de Ciências Naturais e Matemática, subsídios estes que contribuam para a introdução e estabilização de práticas inovadoras em Cursos de Licenciatura e Programas de Educação Continuada de Professores.

O objetivo do trabalho é o desenvolvimento de atividades de formação continuada com docentes de Física em exercício, inserindo a História e Filosofia da Ciência como fios condutores das discussões e foco das experiências didáticas realizadas por eles em sala de aula. Para tanto, a partir dos resultados de um levantamento sobre o perfil dos professores de Ciências, Física, Química, Biologia e Matemática de uma cidade do Estado de São Paulo, elaboramos uma proposta de curso de formação continuada intitula-

1 Departamento de Educação, Grupo de Pesquisa em Ensino de Ciências, Faculdade de Ciências, campus de Bauru, Universidade Estadual Paulista Júlio de Mesquita Filho (Unesp).

2 Docente-adjunto do Departamento de Educação e do Programa de Pós-Graduação em Educação para a Ciência, Grupo de Pesquisa em Ensino de Ciências, Faculdade de Ciências, campus de Bauru, Universidade Estadual Paulista Júlio de Mesquita Filho (Unesp).

3 Processo 48.6080/2006-4 - Edital Universal 02/2006. 
do "A História e a Filosofia da Ciência na prática pedagógica de professores de Física”, com duração de 40 horas-aula.

Acompanhamos o desenvolvimento de cinco professoras que participaram do curso durante o primeiro semestre letivo de 2008 e estavam atuando na disciplina Física no Ensino Médio, apenas duas delas licenciadas em Física.

As professoras, a partir das reflexões realizadas, elaboraram propostas de minicursos levando em consideração aspectos da História e Filosofia da Ciência no ensino, além das concepções alternativas dos estudantes. Os minicursos foram aplicados em situações reais de sala de aula e acompanhados em reuniões de reflexão.

Trata-se de uma pesquisa qualitativa, e o tratamento das informações obtidas foi pautado na análise de conteúdo de acordo com Bardin (1994).

O levantamento inicial realizado não revelou apenas o perfil das professoras, mas também procurou pesquisar entre os participantes em que sentido a universidade poderia colaborar com sua formação e sua prática pedagógica. A necessidade do oferecimento de cursos foi apontada por onze dos 22 professores. ${ }^{4}$

Alguns exemplos:

Oferecendo cursos de capacitação e apoio na parte pedagógica.

Com parcerias na formação continuada, oferecendo oficinas nas quais tivesse a divulgação das pesquisas que o programa vem desenvolvendo.

Com cursos gratuitos que fossem oferecidos em horários que pudéssemos frequentar e que dessem certificados para a nossa evolução funcional.

Com base nas informações obtidas pelos questionários, entramos em contato com os professores por meio de e-mail, enviando o convite para participar do curso. Realizamos também o contato com todas as escolas de Nível Médio da cidade, por meio de e-mail, telefone e, em alguns casos, pessoalmente, a fim de divulgar o curso que foi desenvolvido de acordo com o seguinte conteúdo programático:

1. Fundamentos teóricos sobre o ensino e a aprendizagem de Física: a abordagem construtivista no ensino.

4 No total, foram entrevistados 89 professores de Física, Química, Biologia, Matemática e Ciências. Os 22 a que nos referimos são docentes que estavam lecionando a disciplina Física no Ensino Médio. Destes, apenas oito eram graduados em Física. 
2. Filosofia, História da Ciência e Ensino de Física.

3. Pesquisas recentes sobre o ensino de Física.

4. Formação de professores e sua profissionalização.

5. Elaboração de atividades de ensino.

O modelo de formação sugerido, por meio da utilização de um curso, apresenta segundo Bell (1991, apud Marcelo Garcia, 1999) as seguintes vantagens: 1) pode aumentar os conhecimentos; 2) melhorar as competências e, 3) proporcionar momentos para a reflexão sobre a prática profissional, entre outras.

É importante ressaltar, entretanto, que nossa proposta de formação não se refere a um desenvolvimento estanque, demasiadamente teórico e sem uma preocupação com as aplicações práticas. $O$ curso de formação é considerado apenas como um ponto de partida, e suas atividades presenciais foram complementadas com atividades práticas desenvolvidas em situações reais no Ensino Médio.

Dos 22 professores entrevistados, sete fizeram inscrição no curso; entretanto, apenas cinco frequentaram todas as atividades durante o primeiro semestre letivo de $2008^{5}$.

Durante o segundo semestre, apesar de finalizadas as 40 horas do curso, quatro das professoras decidiram continuar frequentando os encontros, o que foi útil para o amadurecimento dos temas estudados e para a elaboração dos minicursos.

As propostas desenvolvidas por elas foram aplicadas em sala de aula, e na sequência, realizamos duas reuniões de reflexão em que as participantes apresentaram e discutiram os resultados obtidos com os alunos.

Tais dados nos permitiram analisar o impacto da proposta, fornecendo subsídios para avaliar se, ao considerarmos as concepções dos futuros docentes sobre os processos de ensino e aprendizagem e sobre a construção do conhecimento científico, dentro da metodologia sugerida neste estudo, poderíamos contribuir para a aceitação de novas metodologias de ensino.

Neste trabalho, destacamos as propostas desenvolvidas pelas docentes, procurando discutir alguns resultados e as potencialidades deste programa de investigação.

5 Para preservar suas identidades, adotamos nomes fictícios: Denise, Greice, Mariana, Tatiana e Viviane. 


\section{As propostas de minicursos e os resultados da aplicação em sala de aula no Ensino Médio}

Apresentamos a seguir a análise dos planejamentos dos minicursos desenvolvidos pelas docentes. As propostas deveriam incorporar as discussões realizadas durante o curso, tais como a aproximação da História da e Filosofia da Ciência no Ensino de Ciências, CTSA, além das concepções alternativas dos estudantes sobre o tema escolhido.

Para tanto, inicialmente apresentaremos uma síntese dos planos de aula das participantes. Revelamos também uma breve discussão sobre a proposta sugerida pela docente e o que realmente desenvolveu, incluindo suas justificativas e impressões expostas no minisseminário para a apresentação e reflexão sobre os resultados da experiência desenvolvida.

\section{O minicurso de Tatiana}

A professora incorporou algumas das inovações discutidas durante o curso em seu planejamento de ensino. O fio condutor da proposta apresentada é a preocupação com as concepções alternativas dos estudantes, com a aproximação da História e Filosofia da Ciência e as relações entre Ciência, Tecnologia, Sociedade e Ambiente.

O Quadro 1 procura sintetizar as ideias sugeridas pela professora.

O minicurso da professora parte da explicitação das concepções alternativas dos estudantes sobre o tema atração gravitacional. O questionário contém questões utilizadas na literatura.

Em sua apresentação após a aplicação da proposta, Tatiana revela:

Naquele exercício que nós fizemos no meio do curso, de pedir para os alunos responderem questões sobre força e movimento, eu já tinha ficado bem impressionada com as respostas [...] Aqui não foi diferente. O que deixa a gente frustrada é que o que eu queria mesmo era eliminar as concepções deles para que eles aprendessem a científica.

A fala da professora deve ser contextualizada. O tema escolhido por ela já havia sido trabalhado durante o primeiro bimestre com os alunos do primeiro ano do Ensino Médio. Sua escolha pelas leis de Newton foi motivada pelos textos trabalhados durante o curso. 
Quadro 1 - Síntese do planejamento de minicurso sugerido pela professora Tatiana.

\begin{tabular}{|c|c|c|c|c|}
\hline \multicolumn{5}{|c|}{ Tatiana } \\
\hline \multicolumn{5}{|c|}{ Primeiro ano do Ensino Médio } \\
\hline \multicolumn{5}{|c|}{ LEIS DE NEWTON } \\
\hline Aulas & Conteúdo & $\begin{array}{c}\text { Atividade } \\
\text { desenvolvida }\end{array}$ & Objetivos & Avaliação \\
\hline 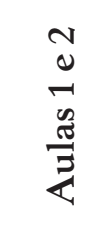 & & $\begin{array}{l}\text { Aplicação de } \\
\text { um questionário } \\
\text { para coletar as } \\
\text { concepções dos } \\
\text { alunos. }\end{array}$ & $\begin{array}{l}\text { Avaliar as } \\
\text { concepções } \\
\text { alternativas dos } \\
\text { estudantes sobre } \\
\text { o tema. }\end{array}$ & $\begin{array}{l}\text { Questões } \\
\text { individuais. }\end{array}$ \\
\hline $\begin{array}{c}\frac{v}{0} \\
\frac{0}{0} \\
\frac{\sigma}{3} \\
\frac{3}{2}\end{array}$ & $\begin{array}{l}\text { 1) O universo aristotélico. } \\
\text { 2) Física na Idade Média - } \\
\text { Philophonos e Buridan. } \\
\text { 3) A Física de Galileu. } \\
\text { 4) As elipses de Kepler. } \\
\text { 5) Dificuldades para a elaboração } \\
\text { de um modelo científico capaz } \\
\text { de explicar os fenômenos } \\
\text { terrestres e celestes. }\end{array}$ & $\begin{array}{l}\text { Aula expositiva } \\
\text { participativa com } \\
\text { discussão dos } \\
\text { conceitos a partir } \\
\text { da utilização de um } \\
\text { texto produzido } \\
\text { pela docente, com } \\
\text { a utilização do } \\
\text { retroprojetor. }\end{array}$ & $\begin{array}{l}\text { Despertar o } \\
\text { interesse pelo } \\
\text { assunto. } \\
\text { Demonstrar a } \\
\text { evolução dos } \\
\text { conceitos. }\end{array}$ & \\
\hline 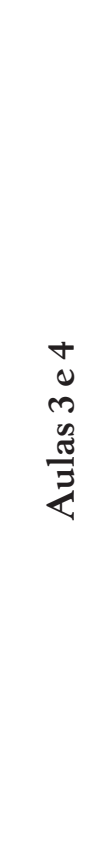 & $\begin{array}{l}\text { 6) A síntese Newtoniana. } \\
\text { 7) A influência dos trabalhos } \\
\text { de outros pensadores. } \\
\text { 8) As leis de Newton. } \\
\text { 9) CTSA: } \\
\text { Satélites artificiais. } \\
\text { Cintos de segurança (inércia). }\end{array}$ & $\begin{array}{l}\text { Aula expositiva } \\
\text { participativa } \\
\text { com o auxílio do } \\
\text { retroprojetor. } \\
\text { Debate em grupos } \\
\text { sobre a questão: } \\
\text { Por que os corpos } \\
\text { caem na superfície } \\
\text { da Terra, e a Lua, } \\
\text { mesmo sendo } \\
\text { atraída pela atração } \\
\text { gravitacional } \\
\text { terrestre, mantém } \\
\text { sua órbita? } \\
\text { Definição das leis } \\
\text { de Newton. }\end{array}$ & $\begin{array}{l}\text { Preparar o } \\
\text { aluno para que } \\
\text { possa aplicar } \\
\text { corretamente as } \\
\text { equações das leis } \\
\text { fundamentais } \\
\text { na resolução de } \\
\text { problemas. } \\
\text { Discutir as } \\
\text { concepções } \\
\text { dos alunos, } \\
\text { buscando uma } \\
\text { evolução. } \\
\text { Verificar a } \\
\text { evolução das } \\
\text { concepções. }\end{array}$ & $\begin{array}{l}\text { Questões } \\
\text { individuais. } \\
\text { Resolução } \\
\text { de } \\
\text { problemas. }\end{array}$ \\
\hline
\end{tabular}

Assim, a aplicação da proposta desenvolvida acabou representando uma espécie de reforço do tema. Contrariando suas expectativas, muitas concepções iniciais ainda estavam presentes nos relatos dos estudantes.

Com relação à aproximação da História da Ciência no ensino, o planejamento foi elaborado com o intuito de demonstrar a evolução dos conceitos, além de evidenciar aos alunos noções historicamente desenvolvidas 
semelhantes às concepções defendidas por eles e despertar o interesse pelo assunto.

A questão da Filosofia foi trabalhada pela docente buscando enfocar a questão dos modelos, da construção do conhecimento.

Isto eu achei que foi um ganho para eles, já que eu pude discutir que a Ciência está em construção. Muitos alunos demonstraram surpresa, porque para eles a Ciência trata com verdades que nunca vão mudar.

Nem todas as atividades programadas puderam ser concluídas. Por falta de tempo disponível, a última parte, referente aos estudos sobre satélites artificiais e sobre os cintos de segurança, planejadas pela professora com o intuito de discutir questões relativas à Ciência, Tecnologia, Sociedade e Ambiente não puderam ser abordadas.

Isso ocorreu devido ao fato de que a professora precisava dar sequência aos estudos do caderno (Proposta Curricular do Estado de São Paulo).

Apesar disso, a parte inicial do planejamento foi respeitada. A tônica do trabalho desenvolvido pela docente baseou-se em aulas expositivas participativas, com a inserção de uma atividade de discussão em grupos.

A avaliação da aprendizagem dos alunos levou em consideração os resultados obtidos nos questionários sobre concepções alternativas, além da participação nos debates e na resolução individual de exercícios na última aula.

Tatiana comenta que:

[...] Em minha prática, eu já costumo avaliar em vários momentos. Então a nota do aluno não é somente a prova escrita, mas também a participação em todas as aulas, em várias atividades. Na medida do possível, eu tento ver se ele está evoluindo.

Quando questionada durante o minisseminário final sobre a possibilidade de se incorporar inovações no dia a dia, a docente sugere ser difícil para um professor em exercício poder preparar e aplicar aulas como as que foram desenvolvidas.

[...] Eu ainda não consegui em minha prática reformular minha forma de trabalhar para poder discutir essas questões em todas as aulas. Temos que seguir a proposta porque somos cobradas o tempo todo, e para trabalhar questões históricas e filosóficas a gente acaba demorando mais. 
Ao final de sua exposição, ao ser questionada sobre possíveis contribuições da experiência desenvolvida para a sua formação/prática e se pretende continuar utilizando as inovações discutidas durante o curso, Tatiana revela:

Sim. Ainda que não tenha conseguido colocar em prática parte do que foi discutido, tenho repensado e refletido muito sobre uma nova abordagem dos conteúdos enfatizando os aspectos históricos e filosóficos. Gostei muito de aprender sobre as concepções. Faz diferença usar o caderno (Proposta Curricular do Estado de São Paulo) sabendo o que está por trás.

\section{O minicurso de Denise}

A proposta de minicurso da professora trata do tema "A Estrutura, Propriedades e Transformações da Matéria”. Denise elaborou seu planejamento a partir da construção histórica do tema como uma forma de introduzir a discussão apresentada pela Proposta Curricular do Estado de São Paulo na disciplina de Química ${ }^{6}$.

O Quadro 2 procura sintetizar as ideias sugeridas pela professora.

As aulas planejadas pela professora seriam desenvolvidas em quatro semanas, sendo as duas primeiras dedicadas ao estudo da construção histórica do tema a partir de textos elaborados por ela. A última parte do planejamento envolve o material da Proposta Curricular do Estado de São Paulo.

Em função do pouco tempo disponível e do cronograma das atividades sugeridas pelo caderno, as aulas acabaram sendo condensadas em duas semanas.

Eu não consegui fazer como eu tinha planejado porque a cobrança na escola para o cumprimento dos capítulos do caderno é muito grande. [...] Eles dizem que o professor pode discutir outras coisas, que pode ampliar [...] Mas nós mal temos tempo para fazer o que está lá na proposta. Eu tive pouco tempo para tratar a parte histórica porque demora, precisa de leitura, né? [...] eu queria que eles percebessem a evolução da Ciência.

Denise expressa em sua fala certa frustração pela relativa perda da autonomia do professor com a nova Proposta Curricular do Estado de São Paulo.

6 Apesar de estar lecionando Física no Ensino Médio, Denise preferiu elaborar seu minicurso a partir do enfoque da Química, sua formação inicial. 
Quadro 2 - Síntese do planejamento de minicurso sugerido pela professora Denise.

\begin{tabular}{|c|c|c|c|c|}
\hline \multicolumn{5}{|c|}{ Denise } \\
\hline \multicolumn{5}{|c|}{ Segundo ano do Ensino Médio } \\
\hline \multicolumn{5}{|c|}{ ESTRUTURA, PROPRIEDADES E TRANSFORMAÇÕES DA MATÉRIA. } \\
\hline Aulas & Conteúdo & $\begin{array}{c}\text { Atividade } \\
\text { desenvolvida }\end{array}$ & Objetivos & Avaliação \\
\hline $\begin{array}{l}2 \\
0 \\
\frac{1}{0} \\
\frac{\sigma}{3} \\
\dot{z}\end{array}$ & $\begin{array}{l}\text { 1) História Antiga: os } \\
\text { primórdios da teoria } \\
\text { Química sobre a Matéria. } \\
\text { 2) Empédocles, Aristóteles, } \\
\text { Léucipo e Demócrito. }\end{array}$ & $\begin{array}{l}\text { Leitura e } \\
\text { discussão de } \\
\text { texto elaborado } \\
\text { pela docente. }\end{array}$ & $\begin{array}{l}\text { Despertar o interesse } \\
\text { pelo assunto. } \\
\text { Demonstrar a evolução } \\
\text { dos conceitos. }\end{array}$ & $\begin{array}{l}\text { Participação } \\
\text { dos alunos. }\end{array}$ \\
\hline 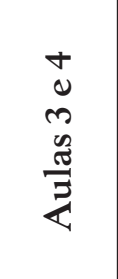 & $\begin{array}{l}\text { 3) Alquimia. } \\
\text { 4) A Revolução Científica: } \\
\text { Paracelso e Stahl. } \\
\text { 5) A teoria do Flogisto. } \\
\text { 6) Lavoisier e a Era } \\
\text { Moderna. }\end{array}$ & $\begin{array}{l}\text { Leitura e } \\
\text { discussão de } \\
\text { texto elaborado } \\
\text { pela docente. }\end{array}$ & $\begin{array}{l}\text { Demonstrar a evolução } \\
\text { dos conceitos. } \\
\text { Discutir a construção } \\
\text { do conhecimento } \\
\text { científico. }\end{array}$ & $\begin{array}{l}\text { Participação } \\
\text { dos alunos. }\end{array}$ \\
\hline $\begin{array}{l}0 \\
0 \\
1 \\
0 \\
0 \\
\frac{\pi}{3} \\
\end{array}$ & $\begin{array}{l}\text { 7) Modelos atômicos: } \\
\text { Dalton, Thonson, } \\
\text { Rutherford, Böhr. }\end{array}$ & $\begin{array}{l}\text { Leitura e } \\
\text { discussão } \\
\text { de texto da } \\
\text { Proposta } \\
\text { Curricular do } \\
\text { Estado de São } \\
\text { Paulo. }\end{array}$ & $\begin{array}{l}\text { Demonstrar a evolução } \\
\text { dos conceitos. } \\
\text { Discutir a construção } \\
\text { do conhecimento } \\
\text { científico. }\end{array}$ & $\begin{array}{l}\text { Participação } \\
\text { dos alunos. }\end{array}$ \\
\hline $\begin{array}{l}\infty \\
0 \\
0 \\
0 \\
\frac{\pi}{3} \\
\sum\end{array}$ & $\begin{array}{l}\text { 8) Continuação da aula } \\
\text { anterior. }\end{array}$ & $\begin{array}{l}\text { Leitura e } \\
\text { discussão } \\
\text { de texto da } \\
\text { Proposta } \\
\text { Curricular do } \\
\text { Estado de São } \\
\text { Paulo. }\end{array}$ & $\begin{array}{l}\text { Demonstrar a evolução } \\
\text { dos conceitos. } \\
\text { Discutir a construção } \\
\text { do conhecimento } \\
\text { científico. }\end{array}$ & $\begin{array}{l}\text { Resolução } \\
\text { de } \\
\text { problemas. }\end{array}$ \\
\hline
\end{tabular}

Sua proposta não incluiu o levantamento das concepções dos estudantes e as relações CTSA. A avaliação é realizada em um único momento, ao final da sequência, por meio de uma lista de exercícios.

Apesar disso, a docente procurou incorporar os temas discutidos durante o curso, tais como a construção do conhecimento científico e a História da Ciência, e revela a intenção de incluí-los em sua prática docente.

Eles gostaram da parte histórica que eu preparei. Eu procurei enfatizar a construção, o movimento dinâmico da Ciência. Apesar do pouco tempo disponível, eu pretendo tentar incorporar a histórica sempre que possível nas minhas aulas. 
Ao final de sua exposição, ao ser questionada sobre possíveis contribuições da experiência desenvolvida para a sua formação/prática e se pretende continuar utilizando as inovações discutidas durante o curso, Denise revela:

Trouxe uma maior conscientização sobre o aspecto de apresentar os conteúdos prontos e acabados de livros didáticos e/ou propostas educacionais. Deve haver uma reflexão maior sobre a prática de como apresentar os conteúdos, sempre buscando maior veracidade dos seus fundamentos científicos. Hoje em dia, as pessoas de modo geral, principalmente os jovens e nós educadores, assimilamos o conhecimento pronto, consumimos e usamos as diversas tecnologias sem mesmo conhecer os princípios de funcionamento e o conhecimento científico que essas tecnologias incorporam. Muita história fica sem ser contada, conhecida e entendida! Além disso, eu tenho refletido mais sobre a minha prática, tentando identificar caminhos de facilitar a aprendizagem dos alunos.

\section{O minicurso de Greice}

A proposta de minicurso da professora trata do tema "Energia" e procura incorporar as inovações discutidas durante o curso, partindo da explicitação das concepções dos estudantes, utilizando a História da Ciência como fio condutor das reflexões com os alunos e discutindo as questões referentes à Ciência, Tecnologia, Sociedade e Ambiente.

O Quadro 3 procura sintetizar as ideias sugeridas pela professora. Sobre a justificativa para a escolha do tema, a professora revela:

Eu quis trabalhar um tema bem do dia a dia deles. Eu quis levá-los a refletir sobre a necessidade cada vez maior de novas fontes de energia e o impacto ambiental que isso tem gerado. Eu achei que seria um tema muito bom para tratar da questão CTSA que a gente estudou aqui no curso.

Sobre a utilização da História da Ciência, Greice comenta:

A base para a elaboração do planejamento foi aquele texto do Matthews ${ }^{7}$ que nós estudamos, onde ele fala das vantagens da utilização da Ciência, como tornar o conhecimento mais interessante, mostrar uma visão de Ciência em construção.

\footnotetext{
7 Matthews, 1994.
} 
Quadro 3-Síntese do planejamento de minicurso sugerido pela professora Greice.

\begin{tabular}{|c|c|c|c|c|}
\hline \multicolumn{5}{|c|}{ Greice } \\
\hline \multicolumn{5}{|c|}{ Segundo ano do Ensino Médio } \\
\hline \multicolumn{5}{|c|}{ ENERGIA } \\
\hline Aulas & Conteúdo & $\begin{array}{c}\text { Atividade } \\
\text { desenvolvida }\end{array}$ & Objetivos & Avaliação \\
\hline $\begin{array}{l}v \\
0 \\
\frac{1}{2} \\
\frac{\pi}{2} \\
\sum\end{array}$ & & $\begin{array}{l}\text { Aplicação de uma } \\
\text { questão para coletar } \\
\text { as concepções dos } \\
\text { alunos sobre o que } \\
\text { é energia. }\end{array}$ & $\begin{array}{l}\text { Avaliar as concepções } \\
\text { alternativas dos } \\
\text { estudantes sobre o tema. }\end{array}$ & $\begin{array}{l}\text { Respostas } \\
\text { individuais. }\end{array}$ \\
\hline $\begin{array}{l}+ \\
0 \\
2 \\
0 \\
\vdots \\
3 \\
3 \\
\end{array}$ & $\begin{array}{l}\text { 1) Evolução } \\
\text { histórica do } \\
\text { conceito de } \\
\text { energia. }\end{array}$ & $\begin{array}{l}\text { Leitura e discussão } \\
\text { de texto elaborado } \\
\text { pela docente. }\end{array}$ & $\begin{array}{l}\text { Reconhecer a Física como } \\
\text { construção humana, } \\
\text { aspectos de sua história e } \\
\text { relações com o contexto } \\
\text { cultural, social, político, } \\
\text { econômico e filosófico. }\end{array}$ & $\begin{array}{l}\text { Participação } \\
\text { dos alunos. }\end{array}$ \\
\hline $\begin{array}{l}0 \\
0 \\
10 \\
0 \\
0 \\
3 \\
3 \\
2\end{array}$ & $\begin{array}{l}\text { 2) Fontes de energia } \\
\text { renováveis e não } \\
\text { renováveis. } \\
\text { 3) Relações CTSA. }\end{array}$ & $\begin{array}{l}\text { Pesquisa } \\
\text { desenvolvida } \\
\text { pelos alunos em } \\
\text { pequenos grupos } \\
\text { como tarefa em } \\
\text { casa. } \\
\text { Debate. }\end{array}$ & $\begin{array}{l}\text { Discutir questões tais } \\
\text { como: a importância da } \\
\text { economia de energia e o } \\
\text { impacto ambiental. }\end{array}$ & $\begin{array}{l}\text { Questão: } \\
\text { Por que } \\
\text { devemos } \\
\text { economizar } \\
\text { energia? }\end{array}$ \\
\hline $\begin{array}{l}\infty \\
0 \\
0 \\
0 \\
0 \\
3 \\
2\end{array}$ & $\begin{array}{l}\text { Energias: } \\
\text { cinética, potencial } \\
\text { gravitacional, solar, } \\
\text { térmica, química, } \\
\text { nuclear, eólica, } \\
\text { luminosa e sonora. } \\
\text { Conservação da } \\
\text { energia mecânica. }\end{array}$ & $\begin{array}{l}\text { Aula expositiva } \\
\text { dialogada. }\end{array}$ & $\begin{array}{l}\text { Utilizar instrumentos } \\
\text { de cálculos matemáticos } \\
\text { na solução de problemas } \\
\text { envolvendo conservação } \\
\text { de energia. }\end{array}$ & $\begin{array}{l}\text { Resolução } \\
\text { de } \\
\text { problemas. }\end{array}$ \\
\hline
\end{tabular}

A professora revela que, apesar das dificuldades, os alunos gostaram do trabalho diferenciado e mais reflexivo.

Os alunos gostaram do trabalho diferenciado, mas a maior dificuldade é que eles têm problemas com a leitura e interpretação de textos. Sem contar a resistência inicial, porque eles acham que leitura é na aula de História ou Português. 
Sobre o impacto da experiência em sua prática, a professora revela que:

Eu trabalhava a Física com definições curtas e resumidas e exercícios. Só. Eu nunca falei de História ou Filosofia da Ciência. O que eu fazia de diferente era usar artigos de revistas, jornais, como a Superinteressante. O resto era matemática aplicada. Agora eu estou descobrindo uma nova forma de ver essas questões.

Ao final de sua exposição, ao ser questionada sobre possíveis contribuições da experiência desenvolvida para a sua formação/prática e se pretende continuar utilizando as inovações discutidas durante o curso, Greice revela:

Hoje eu fico mais preocupada, pois me sinto mais responsável pelo acompanhamento dos alunos. Aquela questão do professor ser autônomo, investigar a prática [...] isso também responsabiliza mais a gente. Eu tento preparar a minha aula hoje baseada naquilo que eu posso fazer dentro do que nós estudamos e estou procurando analisar o que dá mais resultado. [...] O curso trouxe várias contribuições para minha formação, entre outras, consolidou métodos que já faziam parte da minha prática em sala de aula, ampliou o "universo" de pesquisas diversificando o material didático usado nas aulas e promoveu discussões de temas relacionados ao cotidiano dos alunos, esclarecendo dúvidas e apontando soluções.

\section{O minicurso de Mariana}

A proposta de minicurso da professora trata do tema "Etnoastronomia" e se divide em duas partes: 1) Na primeira, trata da diversidade cultural e dos modelos de mundo elaborados por comunidades indígenas brasileiras como temas motivadores para o estudo da Física. 2) Na segunda parte, o estudo de alguns conceitos Físicos presentes no cotidiano das tribos são abordados.

O minicurso procura abordar a questão da História da Ciência e se encaixa na proposta curricular do Estado de São Paulo, que sugere o estudo de modelos explicativos da constituição e origem do Universo, segundo diferentes culturas, buscando semelhanças e diferenças entre suas formulações.

O Quadro 4 procura sintetizar as ideias sugeridas pela professora. 
Quadro 4 - Síntese do planejamento de minicurso sugerido pela professora Mariana.

\begin{tabular}{|c|c|c|c|c|}
\hline \multicolumn{5}{|c|}{ Mariana } \\
\hline \multicolumn{5}{|c|}{ Primeiro ano do Ensino Médio } \\
\hline \multicolumn{5}{|c|}{ ETNOASTRONOMIA } \\
\hline Aulas & Conteúdo & $\begin{array}{c}\text { Atividade } \\
\text { desenvolvida }\end{array}$ & Objetivos & Avaliação \\
\hline $\begin{array}{l}2 \\
0 \\
\frac{1}{2} \\
\frac{3}{3} \\
\frac{\pi}{4}\end{array}$ & $\begin{array}{l}\text { Texto: Lendas } \\
\text { indígenas brasileiras. } \\
\text { O surgimento da vida } \\
\text { na Terra. }\end{array}$ & $\begin{array}{l}\text { Leitura e } \\
\text { discussão do } \\
\text { texto. }\end{array}$ & $\begin{array}{l}\text { Demonstrar que outras culturas } \\
\text { também elaboraram modelos } \\
\text { explicativos sobre a origem e a } \\
\text { constituição do Universo. }\end{array}$ & $\begin{array}{l}\text { Participação } \\
\text { do alunos. }\end{array}$ \\
\hline 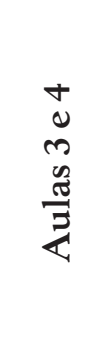 & $\begin{array}{l}\text { A construção social } \\
\text { do céu. } \\
\text { Astronomia indígena. }\end{array}$ & $\begin{array}{l}\text { Leitura e } \\
\text { discussão } \\
\text { do texto } \\
\text { elaborado } \\
\text { pela docente. }\end{array}$ & $\begin{array}{l}\text { Demonstrar que outras culturas } \\
\text { também elaboraram modelos } \\
\text { explicativos sobre a origem e a } \\
\text { constituição do Universo. } \\
\text { Questionar uma visão de mundo } \\
\text { etnocêntrica, introduzindo o } \\
\text { respeito pela diversidade. }\end{array}$ & $\begin{array}{l}\text { Síntese } \\
\text { elaborada } \\
\text { pelos } \\
\text { alunos em } \\
\text { pequenos } \\
\text { grupos. }\end{array}$ \\
\hline $\begin{array}{l}0 \\
0 \\
10 \\
0 \\
0 \\
3 \\
3 \\
2\end{array}$ & $\begin{array}{l}\text { A Física presente no } \\
\text { cotidiano indígena: } \\
\text { alguns exemplos. } \\
\text { A pesca e a refração } \\
\text { da luz. } \\
\text { Agricultura e as } \\
\text { estações do ano. }\end{array}$ & $\begin{array}{l}\text { Aula } \\
\text { expositiva } \\
\text { dialogada. }\end{array}$ & $\begin{array}{l}\text { Demonstrar os conceitos } \\
\text { físicos presentes no cotidiano } \\
\text { indígena. }\end{array}$ & $\begin{array}{l}\text { Resolução } \\
\text { de } \\
\text { problemas } \\
\text { abertos. }\end{array}$ \\
\hline
\end{tabular}

Mariana não inclui em sua proposta o levantamento das concepções alternativas dos estudantes e não procura discutir as relações CTSA.

Em função do pouco tempo disponível, a docente não conseguiu desenvolver a segunda parte de seu planejamento, referente às aulas 5 e 6 .

Ao final de sua exposição, ao ser questionada sobre possíveis contribuições da experiência desenvolvida para a sua formação/prática e se pretende continuar utilizando as inovações discutidas durante o curso, Mariana revela:

Eu achei muito importante discutir esses temas que, mesmo fazendo curso de Física, ficaram fora da minha formação. Eu nunca tinha estudado Filosofia e creio que agora tenho uma visão diferente dos conteúdos e da forma que eles devem ser trabalhados. [...] Não sei se no dia a dia será possível fazer isso sempre, mas agora eu tenho questionado algumas coisas que eu sempre fiz [...] acabei percebendo que nem sempre o aluno não aprende porque é incapaz ou desinteressado. Existem teorias que me ajudaram a compreender as concepções deles. 


\section{O minicurso de Viviane}

A professora Viviane participou das atividades do curso durante o primeiro semestre letivo. Durante o segundo semestre, quando buscamos acompanhar a elaboração e a aplicação dos minicursos, a docente não esteve presente. Dessa forma não temos os dados referentes ao trabalho que seria desenvolvido por ela.

\section{Breve síntese}

O Quadro 5 procura sintetizar as ideias sugeridas pelas professoras em relação aos temas que foram discutidos durante o curso e que deveriam integrar a propostas. A classificação quanto ao nível de engajamento refere-se à preocupação da participante em utilizar, em suas atividades, os aspectos estudados durante o curso.

Quadro 5-Comparativo entre os minicursos.

\begin{tabular}{|c|c|c|c|c|c|c|c|}
\hline $\begin{array}{c}\text { Nível de } \\
\text { engajamento } \\
\text { da proposta. }\end{array}$ & $\begin{array}{c}\text { Aspectos } \\
\text { incorporados } \\
\text { nos minicursos. }\end{array}$ & $\begin{array}{l}\text { Concepções } \\
\text { alternativas }\end{array}$ & $\begin{array}{c}\text { História } \\
\text { da } \\
\text { Ciência }\end{array}$ & $\begin{array}{c}\text { Filosofia } \\
\text { da } \\
\text { Ciência }\end{array}$ & CTSA & $\begin{array}{c}\text { Atividades de } \\
\text { desenvolvimento } \\
\text { e reflexão dos } \\
\text { alunos }\end{array}$ & Avaliação \\
\hline \multirow{3}{*}{$\begin{array}{c}\text { Mais } \\
\text { engajada. }\end{array}$} & Professoras & & & & & & \\
\hline & Greice & $X$ & $\mathrm{X}$ & $\mathrm{X}$ & $X$ & $\mathrm{X}$ & Formativa \\
\hline & Tatiana & $\mathrm{X}$ & $\mathrm{X}$ & $\mathrm{X}$ & $\begin{array}{c}\mathrm{X} \\
\text { (Não teve } \\
\text { tempo } \\
\text { para } \\
\text { aplicar). }\end{array}$ & $\mathrm{X}$ & Formativa \\
\hline & Mariana & Não & $\mathrm{X}$ & $\mathrm{X}$ & $\mathrm{X}$ & $\mathrm{X}$ & Formativa \\
\hline $\begin{array}{c}\text { Menos } \\
\text { engajada. }\end{array}$ & Denise & Não & $\mathrm{X}$ & $\mathrm{X}$ & Não & Não & $\begin{array}{l}\text { Lista de } \\
\text { exercícios } \\
\text { ao final da } \\
\text { sequência. }\end{array}$ \\
\hline
\end{tabular}

\section{Considerações finais}

Nesta pesquisa, buscamos inserir a discussão sobre a aproximação da História e Filosofia da Ciência no Ensino de Ciências dentro das atividades de um curso de formação continuada voltado para docentes que estavam 
lecionando a disciplina Física no Ensino Médio. A proposta procurava evidenciar as dificuldades para a mudança de postura na ação docente, além de propor um modelo de formação que favorecesse a adoção de metodologias de ensino mais voltadas para a construção de conhecimentos.

Iniciamos nosso trabalho revelando as pré-concepções das professoras sobre a construção do conhecimento científico e sobre os processos de ensino e aprendizagem, além de avaliar as opiniões dos participantes sobre a possibilidade de se inserir a História da Ciência no ensino (entrevista de grupo focal).

Os instrumentos utilizados revelaram indicadores que confirmaram os resultados de pesquisas na área de Ensino de Ciências, evidenciando a existência de noções de senso comum que as docentes possuem sobre a Ciência e sobre os processos de ensino e aprendizagem e sua influência sobre a prática docente (Gil Perez, 1991; Hasweh, 1996; Mellado, 1996; Hewson et al., 1999a e b; Levy e Sanmartí, 2001, entre outros).

A análise do questionário VOSTS (Ainkenhead e Ryan, 1992) evidenciou distorções nas concepções das participantes, revelando, por exemplo, a crença em uma imagem da Ciência centrada no conteúdo, desvinculada do aspecto social de sua construção, desenvolvendo-se de forma cumulativa muitas vezes graças a descobertas casuais.

Sobre as concepções a respeito dos processos de ensino e aprendizagem, as professoras demonstraram grande apego ao modelo tradicional, baseado na transmissão e recepção passiva de conhecimentos.

Apesar do reconhecimento da importância da aproximação da História da Ciência no ensino, durante a entrevista de Grupo Focal as docentes revelaram uma série de obstáculos à sua utilização em sala de aula, tais como, por exemplo, a falta de interesse e de conhecimentos prévios dos alunos, além de baixos salários e péssimas condições de trabalho para os professores.

Outro aspecto significativo é que nenhuma das participantes tinha tido contato com a Filosofia da Ciência e, dessa forma, não foram capazes de analisar suas possíveis contribuições para o ensino.

Este levantamento inicial forneceu um panorama que pôde ser usado para o planejamento do trabalho durante o curso, e o detalhamento encontra-se em Gatti e Nardi (2009).

Desenvolvemos nosso trabalho a fim de construir com as docentes uma postura investigativa frente aos problemas da prática. 
O modelo de formação sugerido, por meio da utilização de um curso, demonstrou ser importante na medida em que contribuiu para aumentar os conhecimentos das participantes, além de proporcionar momentos de reflexão sobre a prática profissional.

É importante ressaltar, entretanto, que nossa proposta de formação não se refere a um desenvolvimento estanque, demasiadamente teórico e sem uma preocupação com as aplicações práticas.

O curso de formação foi apenas um ponto de partida, e suas atividades presenciais foram complementadas com atividades práticas desenvolvidas em situações reais no Ensino Médio.

Alguns aspectos merecem destaque:

1) O curso foi o primeiro contato de todas as participantes com a Filosofia da Ciência.

2) Os debates desencadearam reflexões sobre os processos de ensino e aprendizagem de Ciências, já que a forma tradicional de apresentação dos conteúdos como verdades acumuladas historicamente foi questionada.

3) As atividades desenvolvidas, buscando enfatizar o papel investigativo da atividade docente, tais como o levantamento realizado por elas das concepções dos estudantes, com a posterior reflexão em grupo dos resultados, contribuíram para o questionamento da visão tradicional dos processos de ensino e aprendizagem, quando o professor transmite conhecimentos que são incorporados pelos estudantes.

4) As professoras tiveram dificuldades para a compreensão dos resultados de pesquisas, presentes na Proposta Curricular do Estado de São Paulo, já que muitas vezes não têm acesso às discussões na área de Ensino de Ciências.

5) Apesar dos bons resultados obtidos e da participação ativa das professoras no processo, as possibilidades de uma aproximação permanente da prática docente aos resultados de pesquisa estudados ainda são limitadas pelas condições adversas encontradas na realidade escolar, tais como excesso de carga horária, classes superlotadas, pressão para o cumprimento integral da proposta curricular, entre outros.

Os minisseminários finais para a discussão dos resultados do desenvolvimento da proposta em situações reais no Ensino Médio permitiram um 
intercâmbio entre as experiências das professoras, estabelecendo um diálogo aberto, quando as participantes puderam revelar as dificuldades encontradas na realização da experiência.

Apesar de considerarmos que as atividades selecionadas foram adequadas e bem desenvolvidas, isso não garante mudanças permanentes na ação docente das participantes.

Ainda que as professoras tenham apontado a importância dos elementos discutidos durante o curso para o Ensino de Ciências e sua intenção de seguir utilizando as inovações debatidas, não temos elementos que indiquem quais serão as repercussões da experiência desenvolvida para a carreira docente.

A formação de professores comprometidos com a construção do conhecimento científico representa um grande desafio, uma vez que, a formação continuada exige um empenho constante na reflexão e aperfeiçoamento da prática pedagógica. Adams e Krockover (1997) relatam que as noções sobre os processos de ensino e aprendizagem estão tão fortemente arraigadas que podem levar anos para serem modificadas. Desta forma, a formação inicial deve preparar os indivíduos para uma atividade profissional que deve se desenvolver durante toda a vida do docente. Sem oportunidades de continuar desenvolvendo e questionado sua prática, os docentes tendem a regredir.

Outro destaque desta pesquisa refere-se à importância do trabalho colaborativo entre a universidade e as escolas da Educação Básica. O estudo mostrou que muitas das inovações na área de Ensino de Física, construídas pela pesquisa na área, não chegam ao conhecimento dos professores.

Nesse sentido, não basta preparar bons materiais pedagógicos para o professor aplicar em sala de aula se ele não recebeu formação para tanto.

\section{Referências bibliográficas}

AIKENHEAD, G. S.; RYAN, A. G. Students' preconceptions about the epistemology of science. Science Education, v.76, n.6, pp.559-580, 1992.

BARDIN, L. Análise de Conteúdo. Lisboa. Edições 70, 1994, 225 p.

GARCÍA, C. M. Formação de professores: para uma mudança educativa. Portugal: Porto Editora, 1999.

GATTI, S. R. T.; NARDI, R. Práticas Pedagógicas de docentes de Física em exercício: concepções iniciais sobre o papel da História da Ciência no ensino e sobre alguns aspectos dos processos de ensino e aprendizagem. In: XVIII SNEF, 2009, Vitória/ES. Anais... Vitória, 2009. 
GIL PEREZ, D. Que hemos de saber y saber hacer los profesores de Ciencias? Enseñanza de las Ciencias. v.9, n.1, pp.69-77, 1991.

HASWEH, M. Z. Efects of science teachers'epistemological beliefs in teaching. Journal of Research in Science Teaching, v.33, n.1, pp.47-63, 1996.

HEWSON, P. W.; TABACHINICK, B. R.; ZEICHNER, K. M.; BLOMKER, K. B.; MEYER, H., LEMBERGER, J.; MARION, R.; PARK, H., TOOLIN, R. Educating prospective teachers of Biology: introduction and research methods. Science Education, v.83, p.247-273, 1999a.

HEWSON, P. W.; TABACHINICK, B. R.; ZEICHNER, K. M.; LEMBERGER, J. Educating prospective teachers of Biology: findings, limitations and recomendations. Science Education, v.83, p.373-384, 1999 b.

LEVY, M. I. C.; SANMARTÍ PUIG, N. Fundamentos de um modelo de formación permanente del profesorado de Ciencias centrado em la reflexión dialógica sobre las concepciones y las prácticas. Enseñanza de las Ciencias, v.19, n.2, p.269-283, 2001.

MATTHEWS, M. R. Historia, Filosofia e Enseñanza de las Ciencias: la aproximación actual. Revista de Las Ciencias, v.12, n.2, p.255-271, 1994.

MELLADO, V. Concepciones y prácticas de aula de profesores de Ciencias, en las formación inicial de primaria y secundaria. Enseñanza de las Ciencias, v.14, n.3, p 289-302, 1996. 



\title{
7 \\ INCLUSÃO NO ENSINO DE FÍSICA: MATERIAIS \\ E METODOLOGIA ADEQUADOS AO ENSINO DE ALUNOS COM E SEM DEFICIÊNCIA VISUAL
}

\author{
Eder Pires de Camargo ${ }^{1}$ \\ Roberto Nardi ${ }^{2}$
}

\section{Considerações iniciais}

Apresentamos maquetes e estratégias metodológicas de ensino de física adequadas à participação de alunos com e sem deficiência visual. Essas maquetes e estratégias podem ser classificadas em dois grupos, a saber: (1) materiais e métodos para o ensino de conceitos ópticos e (2) materiais e métodos para o ensino do conceito de aceleração da gravidade. Dessa forma, além de temas ligados à mecânica, buscamos apresentar subsídios teóricos e práticos para a abordagem de temas ópticos por parte de professores de física que trabalhem com alunos com deficiência visual. Fazemos esta ressalva, pois, a óptica, devido ao tratamento de fenômenos luminosos, evidencia um maior número de dificuldades e receios no contexto do ensino de física e da deficiência visual. Como mostraremos, os materiais desenvolvidos são adequados não apenas para o ensino dos alunos com deficiência visual, como também dos alunos videntes. Assim, pretendemos que possíveis receios sejam superados pelos professores e que as dificuldades transformem-se em alternativas de ensino para todos os alunos.

Os materiais e métodos resultam de pesquisas de mestrado, doutorado e pós-doutorado sobre a inclusão de alunos com deficiência visual em aulas

1 Professor-adjunto, Departamento de Física e Química, Faculdade de Engenharia, campus de Ilha Solteira, Universidade Estadual Paulista Júlio de Mesquita Filho (Unesp).

2 Professor-adjunto, Departamento de Educação, Faculdade de Ciências, campus de Bauru. Universidade Estadual Paulista Júlio de Mesquita Filho (Unesp). Grupo de Pesquisa em Ensino de Ciências, Programa de Pós-Graduação em Educação para a Ciência. 
de física. Em nosso mestrado, estudamos concepções alternativas de pessoas cegas sobre repouso e movimento (Camargo, 2000). Este estudo trouxe subsídios indispensáveis para a elaboração e condução de atividades de ensino de física para alunos cegos e com baixa visão, investigação esta que caracterizou nosso doutorado (Camargo, 2005). Por fim, a problemática oriunda da relação aluno com deficiência visual/docente de Física motivou nossa pesquisa de pós-doutorado (Camargo, 2006). Nesta pesquisa, estudamos as dificuldades e alternativas enfrentadas por futuros professores ao lecionarem Física em uma sala de aula com 35 alunos videntes e dois com deficiência visual total.

As investigações mencionadas surgiram, portanto, do contexto educacional atual, isto é, o significativo aumento da presença de alunos com deficiências no ensino básico regular. Para se ter uma ideia, entre os anos de 1998 e 2003, a matrícula de alunos com deficiências junto ao ensino regular cresceu aproximadamente $249 \%$. Esse significativo aumento foi consequência direta das orientações da Lei de Diretrizes e Bases da Educação Nacional (Lei 9394/96), que em seu artigo 4 inciso III, recomenda que o atendimento educacional dos alunos com necessidades especiais seja feito, preferencialmente, na rede regular de ensino (Brasil, 1996). Tal recomendação, se por um lado corrige problemas históricos ligados à segregação social de pessoas, por outro pega despreparado grande parte dos docentes, que nunca discutiram em sua formação acadêmica temas ligados ao ensino de alunos com deficiências.

Entretanto, não defendemos a ideia de que a implantação da educação inclusiva deva dar-se somente após a preparação de todos os professores, mesmo porque o referido pré-requisito representaria uma justificativa à existência de espaços educacionais segregativos. Todavia, concordamos com uma relação dialética entre aceitação dos alunos com deficiências na rede regular de ensino e busca de soluções à problemática que se estabelece. Por outro lado, entendemos que uma abordagem teórico-prática por parte de futuros professores nos cursos de licenciatura, bem como de professores ativos em cursos de formação continuada acerca da temática "ensino e alunos com deficiências" pode influir nas atuações desses docentes e, consequentemente, na relação de aceitação e busca de soluções anteriormente mencionada. Como apontam os Parâmetros Curriculares Nacionais, "a inclusão escolar impõe-se como uma perspectiva a ser pesquisada e expe- 
rimentada na realidade brasileira" (Brasil, 1998). Neste sentido, o presente texto representa resultados de pesquisas como as indicadas pelos PCN.

$\mathrm{Na}$ sequência, discutiremos resumidamente o conceito de inclusão escolar de alunos com necessidades educacionais especiais, deixando claro que o conceito da inclusão não se reduz ao ambiente da escola e à deficiência, sendo portanto, mais amplo, isto é, aplicável ao contexto social e de grupos excluídos. Apresentaremos também uma metodologia inclusiva de ensino, metodologia esta que fundamenta a elaboração e aplicação prática dos materiais anteriormente mencionados. Destacaríamos finalmente que, tendo em vista as especificidades educacionais inerentes à deficiência visual, como entrar em contato com o conteúdo físico de ensino sem o auxílio da visão, participar de procedimentos de avaliação sem o auxílio da visão, observar fenômenos sem o auxílio da visão, fazer registros em sala de aula sem o auxílio da visão, etc. este texto limita seu enfoque ao ensino de física e à deficiência visual. Entendemos, contudo, que o tema da inclusão escolar de alunos com deficiências estabelece relações de proporcionalidade direta entre amplitude, importância e complexidade, e merece urgentemente ser investigado.

\section{Referencial teórico}

\section{$A$ inclusão escolar}

Discutiremos agora o conceito de inclusão. Entendemos que esta discussão é necessária para que o professor compreenda suas funções, bem como as dos alunos com e sem deficiência visual, no ambiente da sala de aula.

Conceitua-se inclusão educacional o processo por meio do qual as instituições de ensino se adaptam para poderem incluir, em seus ambientes, pessoas com deficiências e, simultaneamente, estas se preparam para assumir seus papéis nestes ambientes (Sassaki, 1999). De acordo com a conceitualização apresentada, para incluir os alunos com deficiências no ambiente social da sala de aula, as práticas educacionais devem ser alteradas no sentido da valorização da heterogeneidade humana, o que implica a aceitação individual de todos os alunos de acordo com suas condições pessoais (Carvalho e Monte, 1995).

A inclusão contempla três aspectos centrais: (a) a aceitação da pessoa com deficiência no ambiente educacional; (b) a adequação do ambiente 
educacional às características de todos os seus participantes; (c) a adequação, mediante o fornecimento de condições, dos participantes do ambiente às características deste. Para Sassaki (1999), a inclusão constitui um processo bilateral no qual as pessoas com deficiências e o ambiente social buscam, em parceria, equacionar problemas, decidir sobre soluções e efetivar a equiparação de oportunidades para todos. Em outras palavras, a inclusão escolar bem sucedida implica na aceitação de todos os alunos, independentemente de condições sensoriais, cognitivas, físicas, e requer sistemas educacionais organizados que ofereçam respostas adequadas às diversas características e necessidades (Carvalho, 1994). A partir do exposto, destacamos que os materiais e métodos apresentados se fundamentam em princípios inclusivistas, ou seja, "a aceitação das diferenças individuais, a valorização de cada pessoa, a convivência dentro da diversidade humana e a aprendizagem através da cooperação" (Sassaki, 1999, p.42).

Após definirmos inclusão educacional, passaremos a discutir aspectos teóricos da metodologia de ensino que você pode utilizar durante suas aulas. Na sequência, tais características serão explicitadas.

\section{Metodologia de ensino de acordo com preceitos inclusivistas}

A metodologia de ensino adequada à contextos inclusivos fundamenta-se em dois referenciais indissociáveis: (1) dar condições para que os alunos com e sem deficiência visual observem o fenômeno ou representações do fenômeno a ser estudado; e (2) dar condições para que os alunos com e sem deficiência visual participem de um ambiente de aprendizagem de Física. Nesta perspectiva, estamos interpretando que o aprendizado é um subproduto de um processo de realização intencional de ações de explorar, observar, discutir, propor, reformular, processo este realizado nas interações entre os alunos e com o objeto de estudo. É esse ambiente que a prática de sala de aula buscará proporcionar aos seus participantes, isto é, docentes, alunos com deficiência visual e videntes.

De forma mais específica, três componentes práticos e três elementos de estrutura podem ser destacados como características da metodologia inclusiva. São eles: tarefas, grupos e debates (componentes práticos); interação com o objeto de estudo, resolução de problemas e confronto de modelos (elementos de estrutura). Os componentes práticos e os elementos de es- 
trutura se articularão durante o processo de ensino da seguinte maneira: (a) interação com o objeto de estudo (tarefas), (b) resolução de problemas (grupos) e (c) confronto de modelos (debates) (Wheatley, 1991 e Peres et al. 1999). Dessa forma, tanto os componentes práticos quanto os elementos de estrutura objetivam proporcionar aos alunos: (1) condições de observar o fenômeno estudado, (2) condições para análises (qualitativas e quantitativas) de situações problemas, (3) condições para elaborar estratégias e hipóteses para a resolução dos problemas propostos e confrontar as hipóteses elaboradas com a de outros grupos e colegas.

Durante a condução das atividades, o professor deverá orientar a formação dos grupos de alunos, apresentar as questões iniciais e finais, ler textos que levem os alunos à reflexão, organizar o debate por meio de sínteses, lançamentos de questões e contra-exemplos, além de defender o modelo científico. Defendendo o modelo científico, o professor representará a "voz da ciência" durante a discussão. A partir do exposto, atendimentos particularizados serão comuns a todos os alunos, e não apenas aos com deficiência visual. Outro aspecto importante refere-se a atitudes colaborativas entre os alunos. De acordo com o modelo metodológico apresentado, essa colaboração poderá partir de ambos os lados, ou seja, tanto do aluno vidente para o com deficiência visual quanto no sentido contrário. A tendência é a de não focar a deficiência visual como algo dificultador, como um problema, como fragilidade. A tendência é colocar todos os alunos em iguais condições educacionais, ou seja, todos estão sujeitos a ter dúvidas, dificuldades, ideias, todos tem condições de prestar ajuda ou ser ajudados.

$\mathrm{Na}$ sequência, apresentamos os materiais e métodos de ensino anteriormente mencionados. Disponibilizaremos sete maquetes cujo objetivo será o ensino dos temas: raio de luz, reflexão, dispersão e refração da luz, bem como aceleração da gravidade. Junto com os materiais, apresentamos algumas questões que podem ser utilizadas durante os momentos de debate. Seguindo a proposta metodológica descrita anteriormente, você poderá elaborar outras questões e utilizá-las durante a aula. Por isto, seja criativo em suas ações. Temos certeza que gerando canais de comunicação entre você e os alunos com deficiência visual, bem como entre os alunos com e sem a mencionada deficiência, a inclusão representará uma viabilidade educacional, um crescimento na qualidade da aprendizagem de todos os alunos. 


\section{Materiais e métodos inclusivos}

\section{Maquete 1: raio de luz}

A Figura 1 traz representações táteis e visuais sobre raio de luz e suas combinações, paralelos, convergentes e divergentes. Pode ser utilizada junto a alunos com e sem deficiência visual durante o estudo da óptica geométrica. Na sequência, apresentamos uma foto da maquete mencionada.

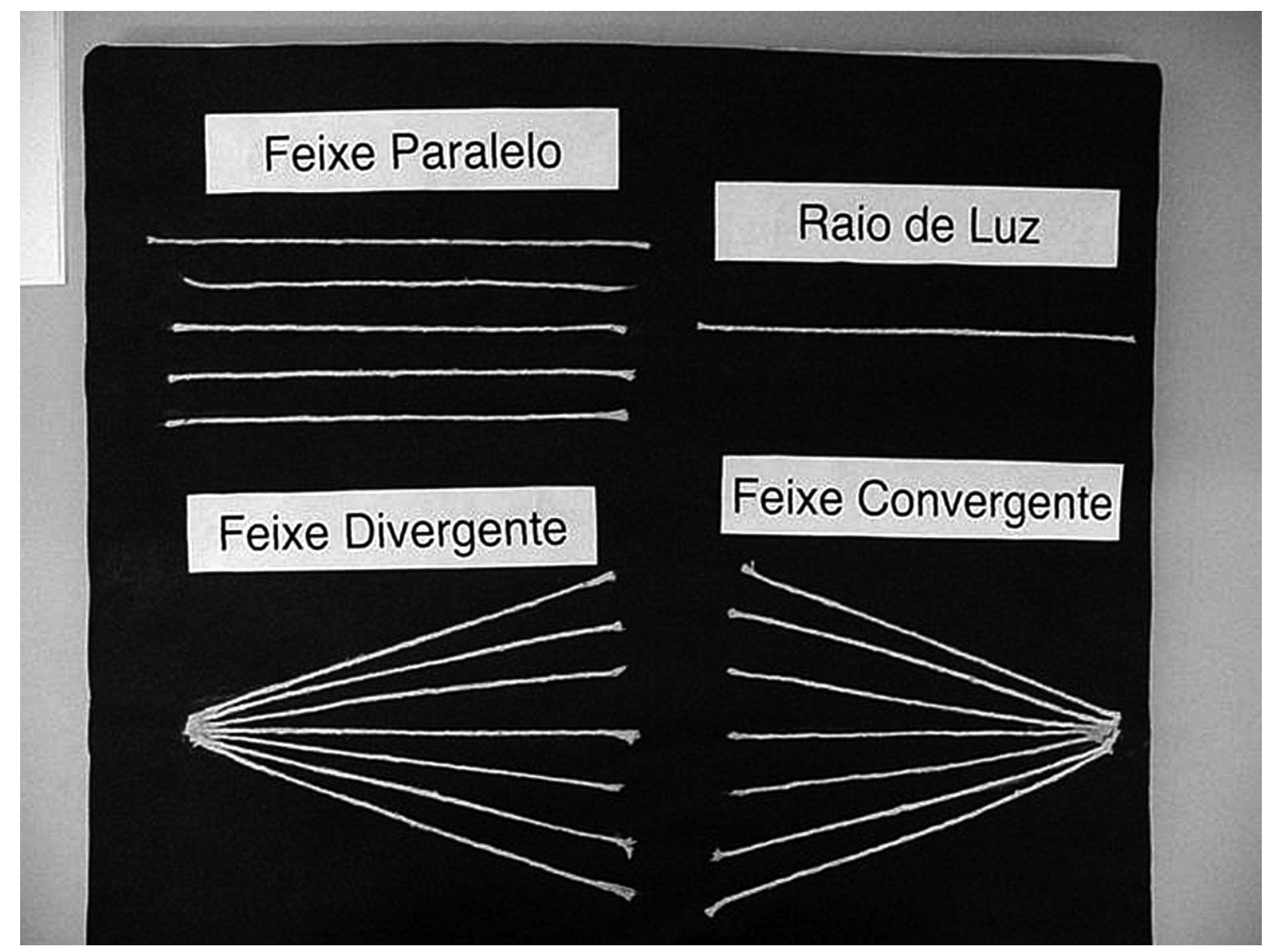

Figura 1 - Representação tátil-visual de raio de luz e suas combinações, paralelos, convergentes e divergentes.

Para a construção da maquete 1, os seguintes materiais devem ser utilizados:

1) Placa de papelão de $40 \mathrm{~cm}$ por $40 \mathrm{~cm}$ de lado.

2) Cartolina preta de $40 \mathrm{~cm}$ por $40 \mathrm{~cm}$ de lado.

3) Quatro metros de barbante.

4) Cola para colar papel, uma folha sulfite, régua e lápis. 
De posse dos materiais descritos, você poderá construir a maquete 1 da seguinte maneira:

1) Cole a cartolina preta sobre o papelão e em seguida divida-os em quatro partes (estrutura de papelão) iguais.

2) Recorte fitas do papel sulfite de $3 \mathrm{~cm}$ por $18 \mathrm{~cm}$ de lado e escreva nessas fitas os seguintes dizeres: feixe de raios paralelos, raio de luz, feixe convergente, feixe divergente. Se possível, escreva os dizeres mencionados em tinta e em braile. Para isto, procure a sala de recurso de sua escola ou a diretoria de ensino. Geralmente, nas salas de recurso trabalham profissionais que sabem escrever em braile e que poderão lhe auxiliar nesta tarefa.

3) Cole uma fita com os mencionados dizeres em cada estrutura de papelão recortado.

4) Recorte 20 pedaços de barbante com $20 \mathrm{~cm}$ de comprimento cada.

5) Com o auxílio da régua e do lápis, trace nas estruturas de papelão esquemas dos feixes paralelos, convergentes, divergentes e do raio de luz.

6) Com o auxílio da cola, fixe os pedaços de barbante sobre os esquemas dos feixes paralelos, convergentes, divergentes e do raio de luz

Essa maquete é útil para você trabalhar as definições de raios paralelos, convergentes e divergentes. Por fundamentar-se em representações táteis e visuais, cria um canal de comunicação para que você explique ao aluno com deficiência visual que a reta que representa o raio de luz indica a direção de sua trajetória de propagação. Porém, antes de você apresentar as definições, é conveniente que os alunos exponham suas ideias e conceitos sobre luz. Para os alunos com deficiência visual, tal exposição é importante, visto que o conhecimento deles sobre luz é influenciado principalmente pelas descrições das pessoas que enxergam (Almeida et al. 2005). Por outro lado, é importante que você conheça algumas das ideias dos alunos com e sem deficiência visual sobre luz. O conhecimento dessas ideias pode orientar as explicações que você apresentará. Para isto, organize um debate entre os alunos com e sem deficiência e, nesse debate, discuta questões relacionadas à luz. Apresentaremos na sequência algumas dessas questões. É claro que você poderá elaborar outras. 
1) Na sua opinião, o que é a luz?

2) Para você, a luz se movimenta? Como?

3) Para você, o que é a visão?

4) Para você, como ocorre a visão?

\section{Maquete 2: reflexão regular}

A Figura 2 visa auxiliar o professor em atividades de ensino que abordem o fenômeno da reflexão da luz. Essa maquete, por disponibilizar representações táteis e visuais, pode ser utilizada junto a alunos com e sem deficiência visual. Na sequência, apresentamos uma foto da referida maquete.

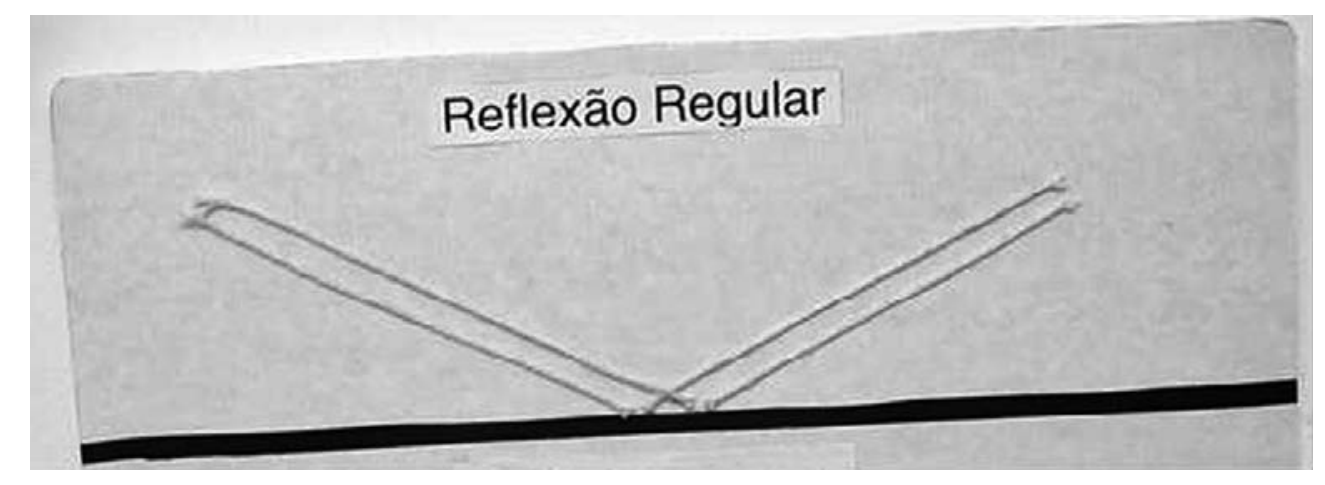

Figura 2 - Representação tátil-visual do fenômeno reflexão regular.

Para construir a maquete 2, utilize os seguintes materiais:

1) Placa de papelão (fundo branco) de $40 \mathrm{~cm}$ por $40 \mathrm{~cm}$ de lados.

2) $80 \mathrm{~cm}$ de barbante.

3) Fita adesiva.

4) Cola para colar papel, uma folha sulfite, régua, lápis e estilete.

Monte a maquete 2 da seguinte forma:

1) Com o auxílio da régua e do lápis, trace na parte inferior da estrutura de papelão uma margem de $5 \mathrm{~cm}$.

2) Sobre essa margem, cole a fita adesiva.

3) Utilizando a régua e o lápis e obedecendo às leis da reflexão regular (ângulo de incidência igual ao de reflexão), trace os raios incidente e refletido sobre a fita colada

4) Cole os pedaços de barbante sobre esses traços. 
Você poderá utilizar a maquete 2 no seguinte contexto educacional:

1) Organize grupos de alunos. É importante que os grupos sejam formados por alunos com e sem deficiência visual.

2) Apresente um espelho plano aos alunos videntes e solicite para que eles olhem o espelho de frente e de lado.

3) Apresente aos alunos videntes a seguinte questão: Por que quando você olha de frente para o espelho você vê seu rosto e de lado não?

4) Apresente aos alunos com deficiência visual as seguintes questões:

4.1) O que você acha que é um espelho?

4.2) Por que você acha que as pessoas usam o espelho?

4.3) Para você, o que acontece no espelho quando as pessoas olham para ele? Por que acontece isso?

4.4) O que é, para você, uma imagem?

Para explicar aos alunos com e sem deficiência visual o fenômeno da reflexão, utilize a maquete 2. Para o caso dos alunos com deficiência visual, faça-os tocar na estrutura tátil da maquete. Esse material, em conjunto com as questões e a atividade em grupo, darão condições para que você trabalhe os fenômenos da reflexão regular e da formação de imagem em espelhos planos junto aos alunos com e sem deficiência visual. Atente-se ao fato de que os alunos com deficiência visual estarão abordando um fenômeno não observado diretamente por eles. Por isto, valorize e utilize as opiniões desses alunos durante o processo de ensino. Valorize também as descrições apresentadas pelos alunos videntes. Esse processo descritivo é importante, pois é pela via social que o fenômeno inerente à reflexão chegará aos alunos com deficiência visual. Para finalizar, organize na sala de aula um debate geral entre os grupos de alunos. Durante esse debate, você poderá trazer informações sobre os fenômenos da reflexão e da formação de imagem, seguro de que os alunos com deficiência visual não estarão abordando algo desconhecido deles.

\section{Maquete 3: refração da luz}

A Figura 3 traz representações táteis e visuais do fenômeno da refração da luz. Por este motivo, é adequada para ser utilizada junto a alunos com e sem deficiência visual. Na sequência, apresentamos uma foto da mencionada maquete. 


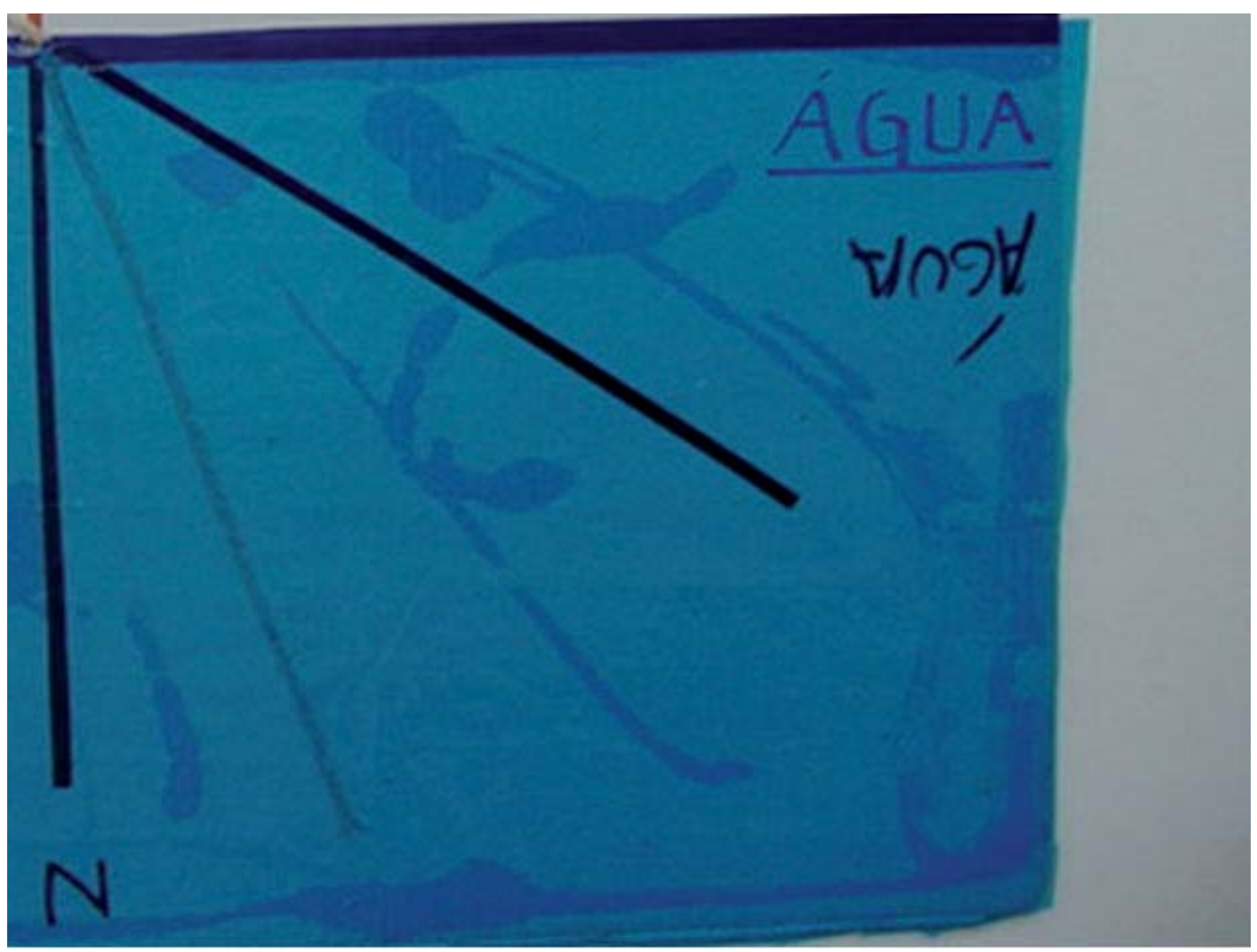

Figura 3 - Representação tátil-visual do fenômeno da refração da luz.

Para construir a maquete 3 , utilize os materiais listados na sequência:

1) Placa de papelão (fundo branco) de $40 \mathrm{~cm}$ por $40 \mathrm{~cm}$ de lado.

2) $40 \mathrm{~cm}$ de barbante.

3) Uma folha de papel celofane azul.

4) Fitas adesivas coloridas (3 cores distintas para confeccionar faixas estreitas).

5) Régua, cola, lápis e folha de papel sulfite.

Para montar a maquete 3 , siga os procedimentos descritos abaixo:

1) Divida o papelão ao meio, marcando com o lápis uma linha divisória.

2) Sobre essa linha, cole uma fita de $1 \mathrm{~cm}$ de largura e $40 \mathrm{~cm}$ de comprimento. Essa fita representará o dióptro plano (superfície de separação entre os meios).

3) De forma aleatória, escolha uma das metades para ser o meio mais refringente, e a outra, o menos refringente.

4) Utilizando lápis e régua, trace a normal à superfície de separação dos meios, o raio incidente, o raio refratado, bem como o prolongamento da trajetória do raio de luz incidente após a refração. 
5) Sobre o traçado da reta normal, cole uma fita de largura menor e de cor diferente da utilizada como dióptro plano.

6) Sobre o traçado do prolongamento do raio incidente, cole uma fita adesiva de cor diferente das fitas utilizadas para representar a reta normal e o dióptro plano.

7) Sobre os traçados dos raios incidentes e refratados, cole pedaços de barbante.

8) Na parte da maquete que representará o meio "água", cole o papel celofane azul. Para que tanto o barbante quanto as fitas adesivas possam ser percebidas tatilmente, tome o cuidado de esticar bem o papel celofane.

9) Escreva em fragmentos da folha sulfite as palavras: ar e água. Cole esses fragmentos nas partes que representam os meios ar e água. Isso identificará visualmente os referidos meios. Preferencialmente, escreva essas palavras em tinta e em braile. Isto facilitará a identificação dos meios pelo aluno com deficiência visual.

Você poderá utilizar essa maquete no seguinte contexto educacional:

1) Apresente aos alunos videntes um copo com água com um lápis colocado de forma inclinada em seu interior.

2) Peça aos alunos videntes para que descrevam como aparenta estar o lápis, ou seja, reto ou torto.

3) Pergunte a eles, bem como aos alunos com deficiência visual: Na opinião de vocês, o lápis realmente entorta quando imerso em água, ou apenas aparenta estar torto. Por quê? É conveniente mostrar aos alunos o lápis antes de ter sido colocado dentro do copo. Para o caso dos alunos com deficiência visual, deixe-os tocar o lápis.

4) Promova entre os alunos um debate sobre suas opiniões acerca do lápis torto ou reto. Tome o cuidado de fazer com que os alunos com deficiência visual externizem suas opiniões e dúvidas. Como esses alunos estarão discutindo um fenômeno não observado por eles, é muito importante que eles conheçam os relatos dos alunos videntes. Na mesma medida, é muito importante que suas interpretações venham à tona, a fim de que você tenha subsídios para o tratamento de tais interpretações. 
5) Utilize a maquete 3 para explicar aos alunos o motivo de o lápis parecer torto dentro do copo. Faça os alunos com deficiência visual tocarem a maquete e perceberem a mudança de direção do raio de luz ao passar da água para o ar.

6) Utilize a maquete 3 para explicar aos alunos que a luz pode afastar-se ou aproximar-se da normal, dependendo do sentido de propagação dos raios de luz (do meio mais para o menos refringente ou do meio menos para o mais refringente). Para tanto, você pode apresentar a maquete 3 na posição conveniente. Para finalizar, explique aos alunos que, na refração, somente ocorre desvio da luz quando esta incide obliquamente na superfície de separação de dois meios físicos. Quando a luz incide perpendicularmente à superfície, ocorre a refração, contudo, sem desvio, apenas com variação de sua velocidade de propagação.

\section{Maquete 4: dispersão da luz}

Esse material traz representações táteis e visuais do fenômeno da dispersão da luz em um prisma. Por este motivo, pode ser utilizado com os alunos com e sem deficiência visual. Apresentamos abaixo uma foto dessa maquete.

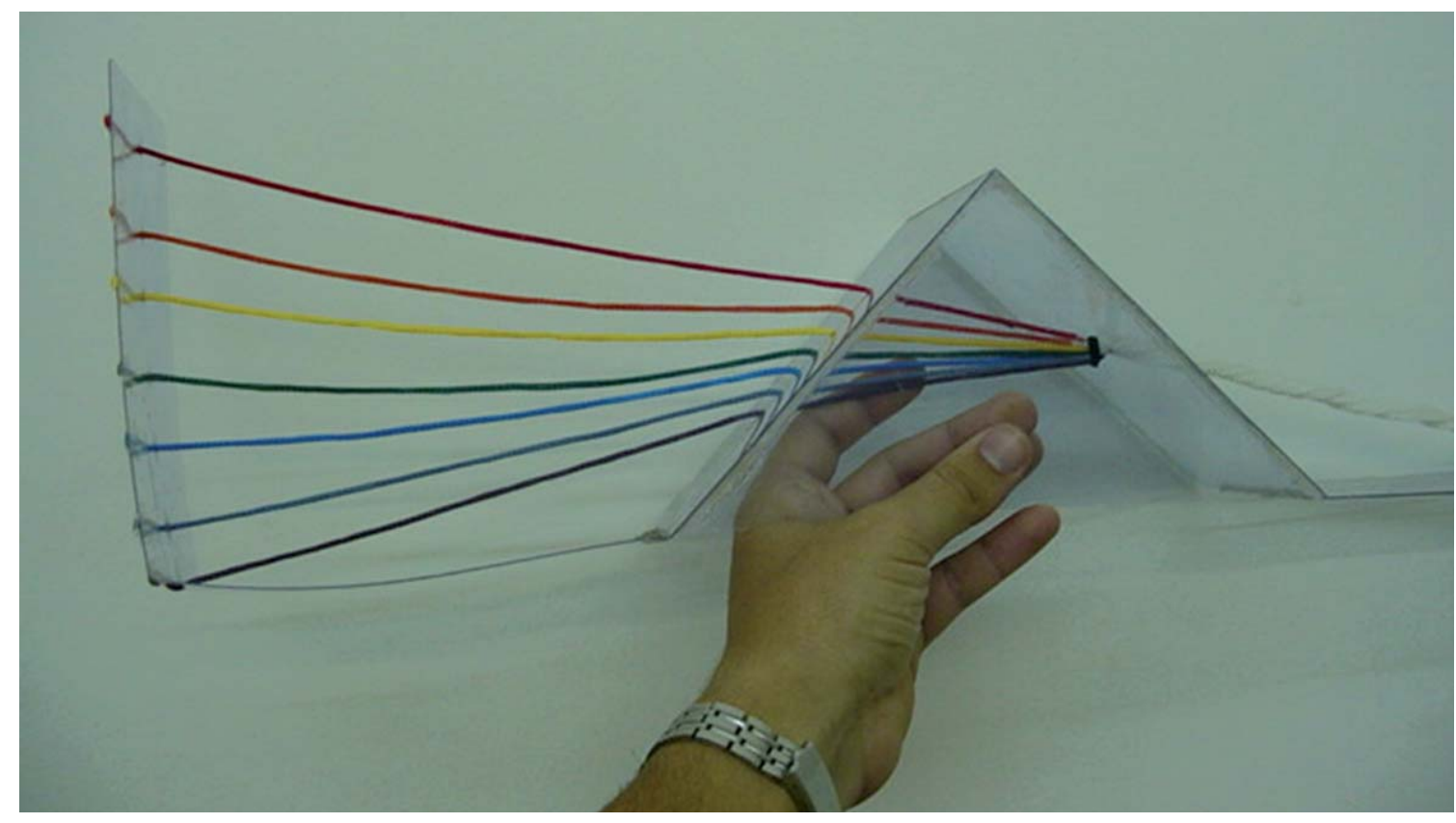

Figura 4 - Representação tátil-visual da dispersão da luz branca em um prisma. 
Para construir a maquete 4 , utilize os seguintes materiais:

1) 2 metros quadrados de chapa de acrílico de $1 \mathrm{~mm}$ (ou material semelhante).

2) Cola de silicone (cola quente).

3) 4 metros de barbante.

4) Três tubos de guache nas cores primárias.

A fim de montar a maquete 4 , siga os procedimentos descritos:

1) Recorte no acrílico dois triângulos equiláteros com aresta de 16 $\mathrm{cm}$, dois retângulos de $16 \mathrm{~cm}$ por $10 \mathrm{~cm}$ de lados, um retângulo de $20 \mathrm{~cm}$ por $8 \mathrm{~cm}$ de lado, e outro retângulo de $45 \mathrm{~cm}$ por $8 \mathrm{~cm}$ de lado.

2) Corte sete barbantes de $70 \mathrm{~cm}$ de comprimento.

3) Cole com a cola de silicone os acrílicos triangulares aos retangulares de $16 \mathrm{~cm}$ por $10 \mathrm{~cm}$, de modo que formem um prisma sem o fundo.

4) Depois de colados, fure um dos retângulos em seu centro (o furo deve ser suficiente para a passagem de sete barbantes entrelaçados). No outro retângulo, faça sete furos equidistantes, de forma que passe por eles apenas um barbante.

5) Enrole os barbantes e passe pelo furo maior. Os barbantes enrolados representarão o raio de luz branca.

6) Cole no prisma, do lado onde há apenas um furo, o retângulo de acrílico de $20 \mathrm{~cm}$ por $8 \mathrm{~cm}$. Faça um outro furo, próximo a uma das pontas, para a passagem dos sete barbantes trançados.

7) Passe os barbantes por esse furo e cole-os de modo que fiquem fixos nas duas pontas. Está pronto o feixe de raio incidente.

8) Dentro do prisma (sem fundo), separe os barbantes e utilize o guache com as cores primárias para produzir as sete cores do arco-íris (vermelho, alaranjado, amarelo, verde, azul, anil e violeta).

9) Pinte o restante dos barbantes, cada um com uma cor.

10) Passe os barbantes pelos furos do outro lado do prisma seguindo a ordem do arco-íris, ou seja, o violeta na parte inferior e o vermelho na parte superior. 
11) Cole do lado do prisma onde estão os sete furos o retângulo maior (45 cm por $8 \mathrm{~cm}$ ) e dobre-o ao meio, formando um "L".

12) Na parte do $L$ que ficou para cima, faça novamente sete furos equidistantes, tomando o cuidado de espaçá-los mais que os contidos no interior do prisma.

13) Passe os barbantes por esses furos na mesma ordem que os que saíram do prisma, fixando-os ao acrílico.

Essa maquete poderá ser utilizada no seguinte contexto educacional:

1) Coloque um prisma de água sobre um retroprojetor ligado e peça para os alunos videntes observarem as características da luz emitida pelo retro. Nessas condições, a luz do retro, ao passar pelo prisma, será decomposta, e as cores do arco-íris aparecerão na tela de projeção.

2) Peça aos alunos videntes para que descrevam suas observações.

3) Peça aos alunos videntes para que relacionem suas observações a algo conhecido deles. Muito provavelmente, eles relacionarão suas observações ao fenômeno do arco-íris.

4) Pergunte a todos os alunos o que é o arco-íris, o porquê de suas cores, de sua forma, quando ele aparece etc.

Essas questões são muito importantes por dois motivos: (a) como os alunos com deficiência visual estarão abordando um fenômeno não observado por eles, as declarações dos alunos videntes estarão descrevendo características inerentes a tal fenômeno. Isto é importante para que os alunos com deficiência visual elaborem representações iniciais acerca do tema tratado; (b) você terá acesso às ideias prévias dos alunos, e isto é fundamental à qualidade das orientações que você prestará a eles.

5) Utilize a maquete 4 para a explicação do fenômeno da dispersão da luz. Note que essa maquete, por trazer representações táteis e visuais, poderá ser utilizada para a orientação de todos os alunos, com ou sem deficiência visual. Explore junto aos alunos o referencial tátil oferecido pela maquete. Temos notado que o tato é um sentido muito importante para a construção de conhecimento científico, já que é potencialmente analítico e detalhista (Soler,1999). Dessa forma, as 
ideias geométricas do fenômeno da dispersão seriam mais adequadamente abordadas pela via tátil do que pela visual. Dentre tais ideias, destacaríamos: (a) a luz branca é policromática, e (b) a luz branca é decomposta ao passar pelo prisma. Verificamos que quando o aluno toca em representações táteis das ideias mencionadas, cria significados melhores estruturados do que os influenciado pelas observações visuais, que, em geral, são mais sintéticas.

\section{Maquete 5: plano inclinado com interface auditiva}

A Figura 5 apresenta um referencial auditivo para o movimento de um carrinho em um plano inclinado. Dessa forma, pode ser utilizada junto a alunos com e sem deficiência visual.

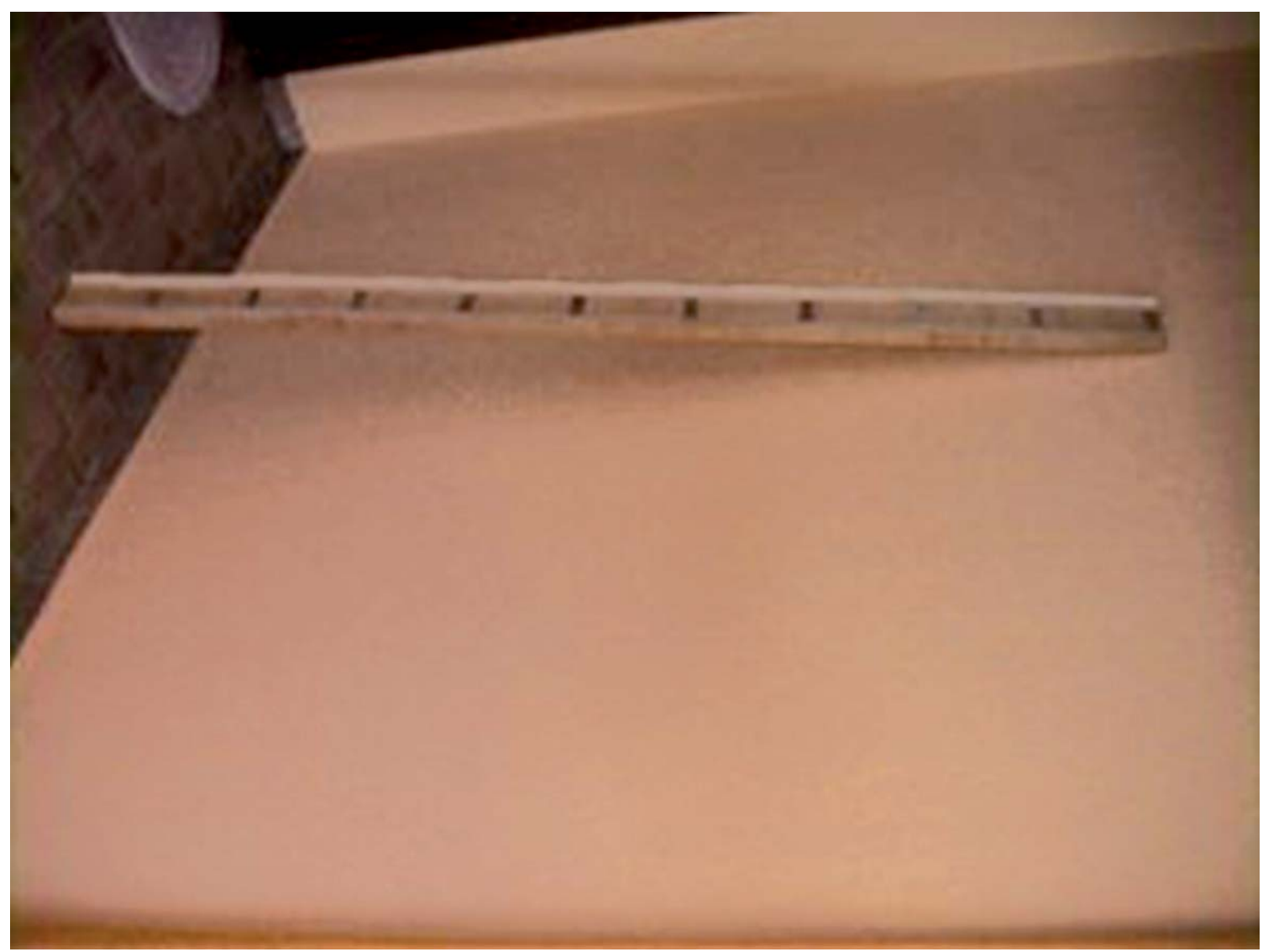

Figura 5 - Plano inclinado com interface sonora. 


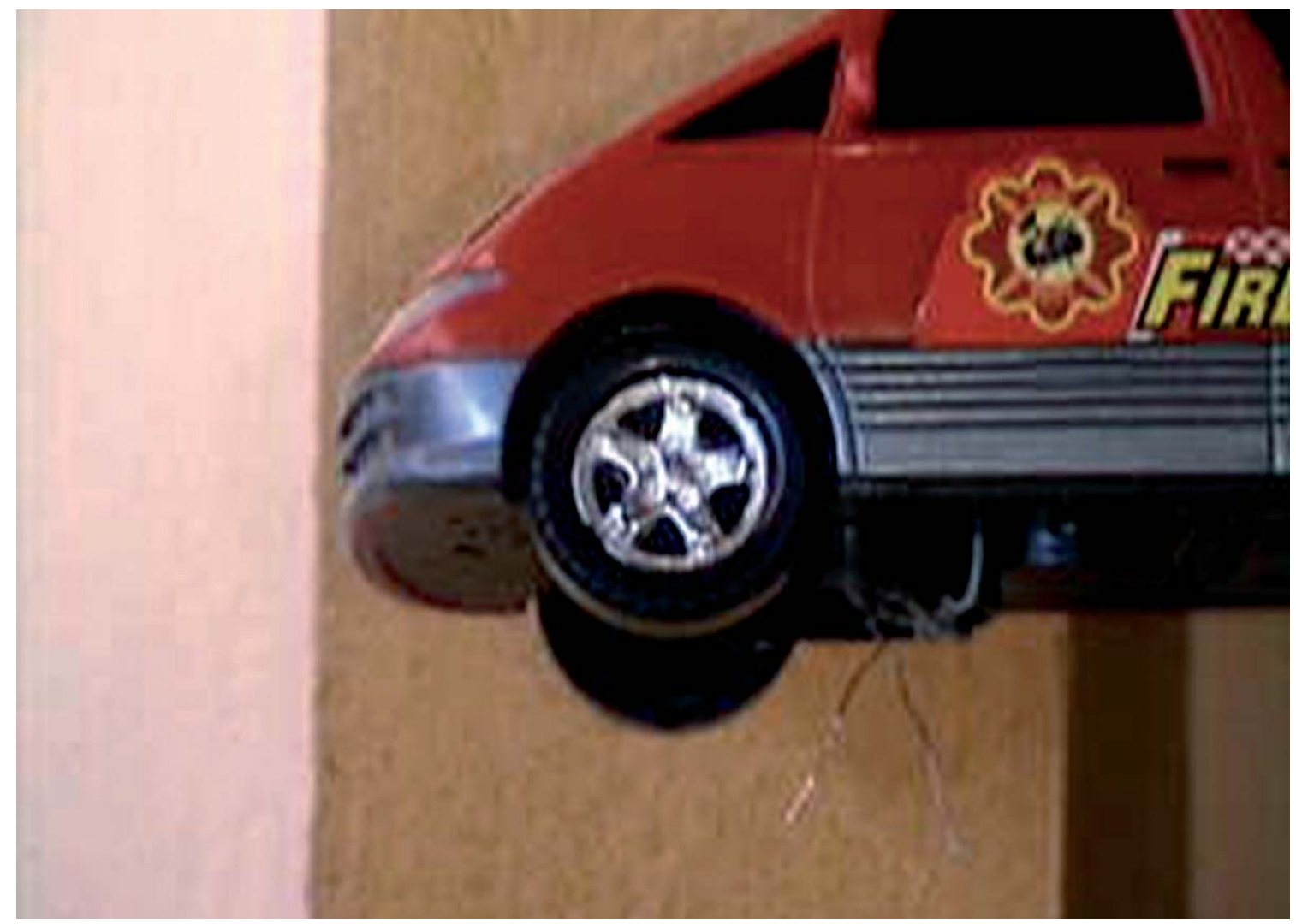

Figura 6 - Carrinho com os fios de ligação expostos.

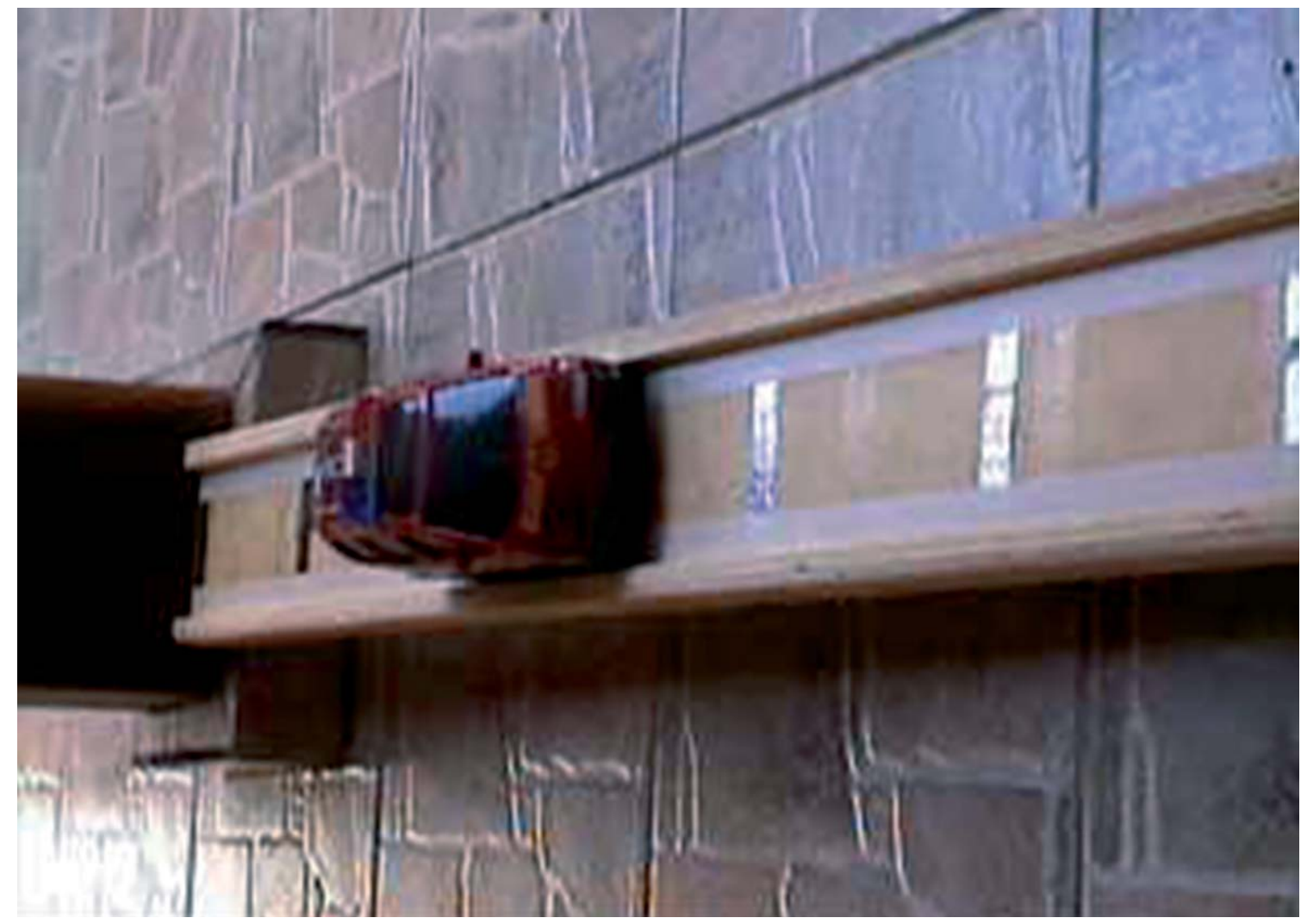

Figura 7 - Carrinho sobre o plano inclinado. 
Para a construção da maquete 5, utilize os seguintes materiais:

1) Superfície de madeira de $2 \mathrm{~m}$ de comprimento por $15 \mathrm{~cm}$ de largura.

2) Fitas de papel alumínio de aproximadamente $15 \mathrm{~cm}$ de comprimento por $1 \mathrm{~cm}$ de largura.

3) Carrinho de brinquedo com os fios do circuito elétrico expostos.

4) Duas baterias de 1,5 v para alimentar o carrinho.

5) Alguns blocos de madeira para variar a inclinação da superfície de madeira.

A construção da maquete 5 obedece aos seguintes procedimentos:

1) Construção do plano inclinado: a superfície do plano inclinado deve variar espaços condutores (fitas de papel alumínio), e espaços isolantes (madeira). A dimensão dos espaços deve ser a mesma, ou seja, $19 \mathrm{~cm}$ de superfície isolante seguido de $1 \mathrm{~cm}$ de superfície condutora. De acordo com as medidas dispostas, haverá aproximadamente 10 espaços isolantes e 10 espaços condutores (ver figura 5).

2) Adaptação do carrinho: adaptamos um carrinho de brinquedo de tal forma que o circuito elétrico constituído pela sirene do carrinho e as baterias fica aberto, com os fios de ligação expostos (ver figura 6). Desse modo, a sirene do carrinho emitirá um som quando os fios de ligação tocarem a parte condutora do plano inclinado (papel alumínio), e deixará de emitir som quando os fios condutores tocarem a parte isolante do referido plano (madeira).

Esse material pode ser utilizado para o estudo do movimento do carrinho sobre o plano inclinado. Para tanto, você pode seguir as sugestões listadas na sequência.

1) Com um impulso dado pelas mãos, fazer com que o carrinho suba o plano inclinado. $\mathrm{O}$ aluno poderá observar auditivamente a diminuição da velocidade do carrinho por meio do aumento do intervalo de tempo entre um sinal e outro da sirene.

2) Deixe o carrinho descer o plano inclinado. $\mathrm{O}$ aluno poderá observar auditivamente o aumento da velocidade do carrinho, por meio da diminuição do intervalo de tempo entre um sinal e outro da sirene.

3) Com o apoio de blocos de madeira, o ângulo do plano inclinado poderá ser variado e, dessa forma, o aluno poderá fazer outras comparações entre os intervalos de tempo de emissão do som da sirene e a variação da velocidade do carrinho. 
4) Em grupo, solicite aos alunos para que discutam e apresentem suas explicações para a variação do intervalo de tempo dos sinais emitidos pela sirene.

5) Proporcionar um debate entre os grupos, para que eles possam apresentar suas conclusões sobre o fenômeno observado. Não estamos limitando a ideia de observação ao aspecto puramente visual. Pelo contrário, estamos estendendo esse conceito aos referenciais auditivos, táteis, etc.

6) Durante esse debate, o professor poderá apresentar os argumentos científicos sobre o tema em questão, funcionando, dessa forma, como mais um grupo participante da discussão.

\section{Maquete 6: equipamento para análises qualitativas e quantitativas do movimento de queda de um objeto}

Esse equipamento apresenta um referencial auditivo da queda de um objeto. Como os anteriores, pode ser utilizado junto a alunos com e sem deficiência visual.

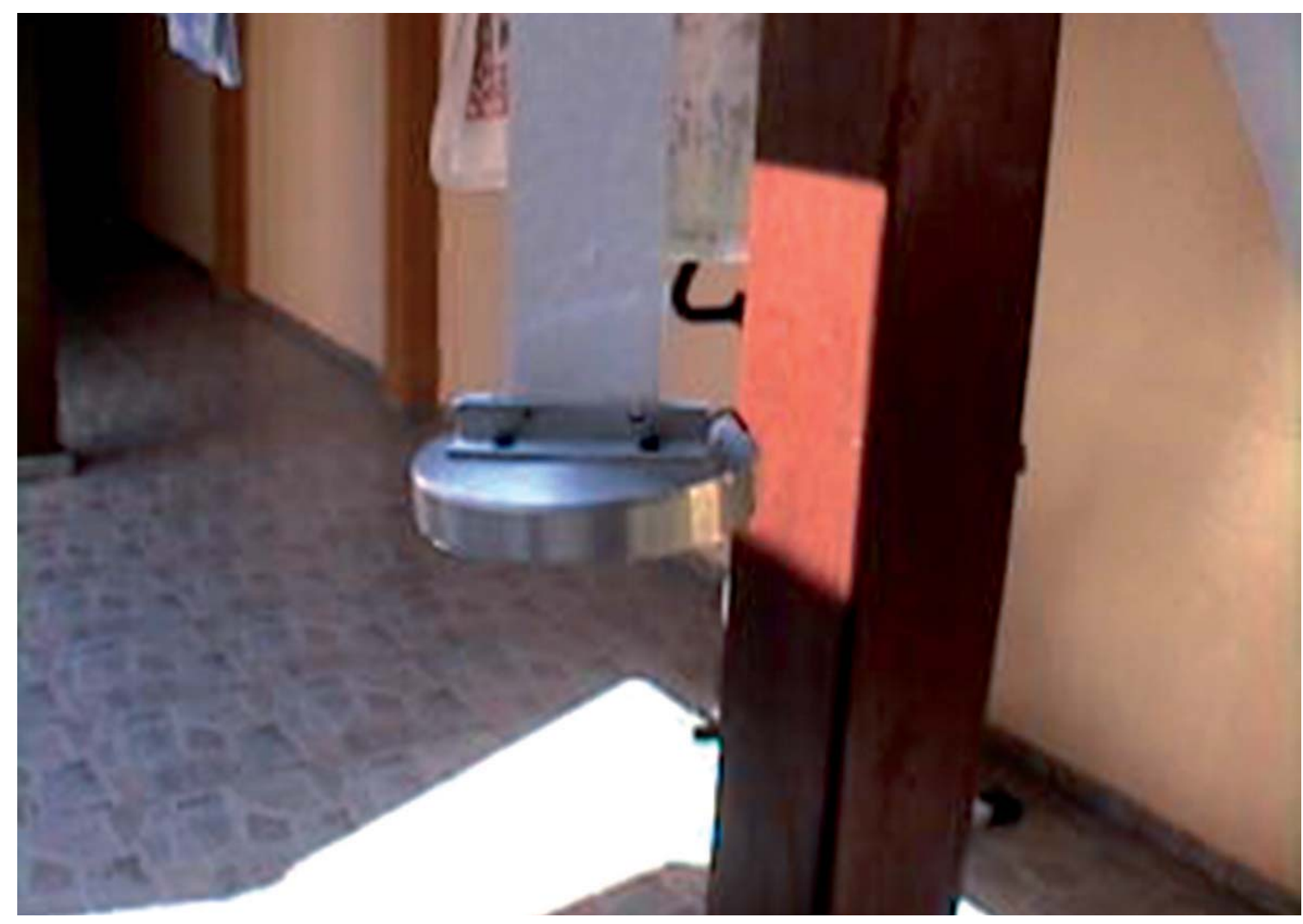

Figura 8 - Tubo de PVC: estrutura para a queda do disco. 


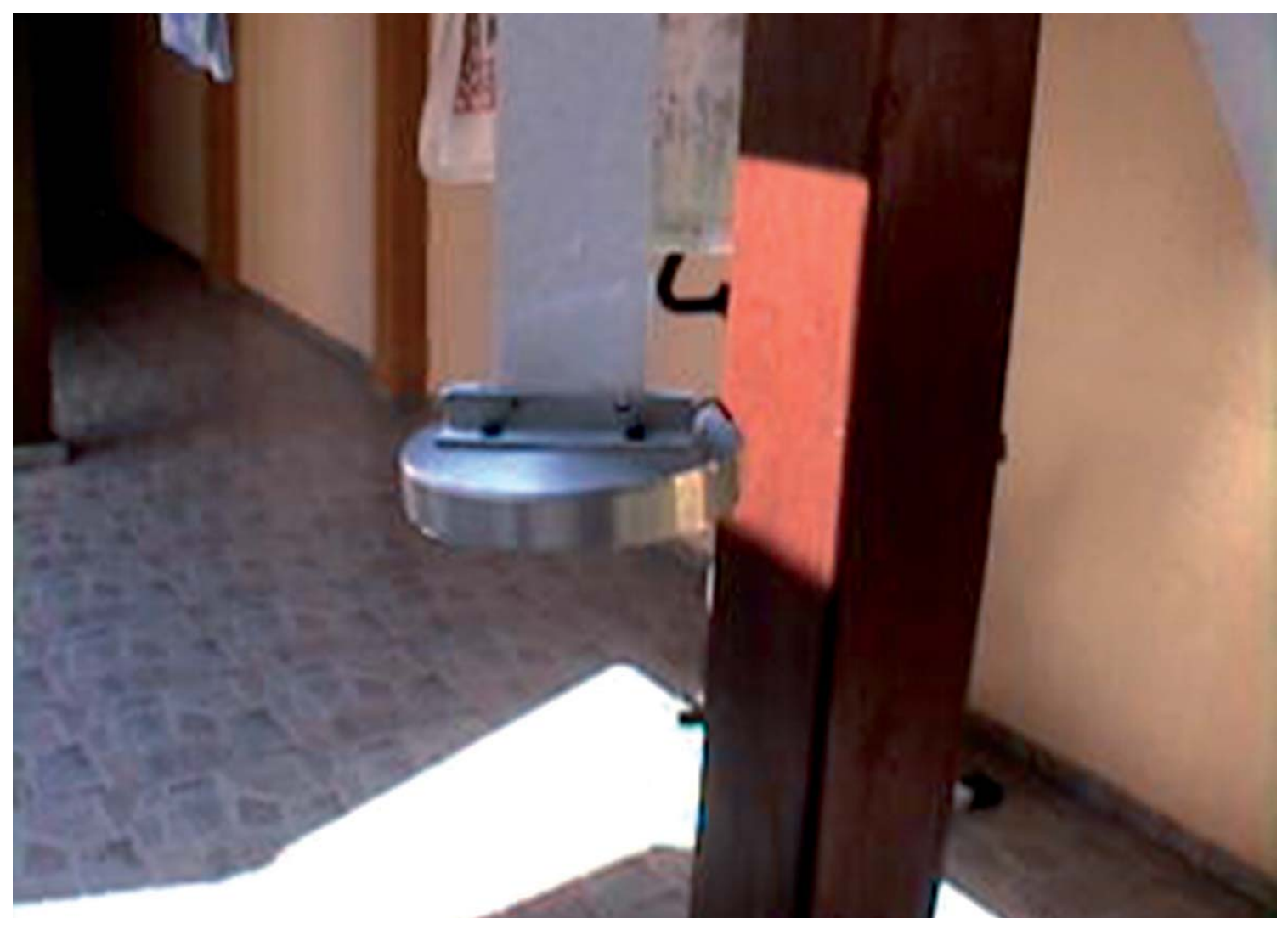

Figura 9 - Fita de papel presa ao disco.

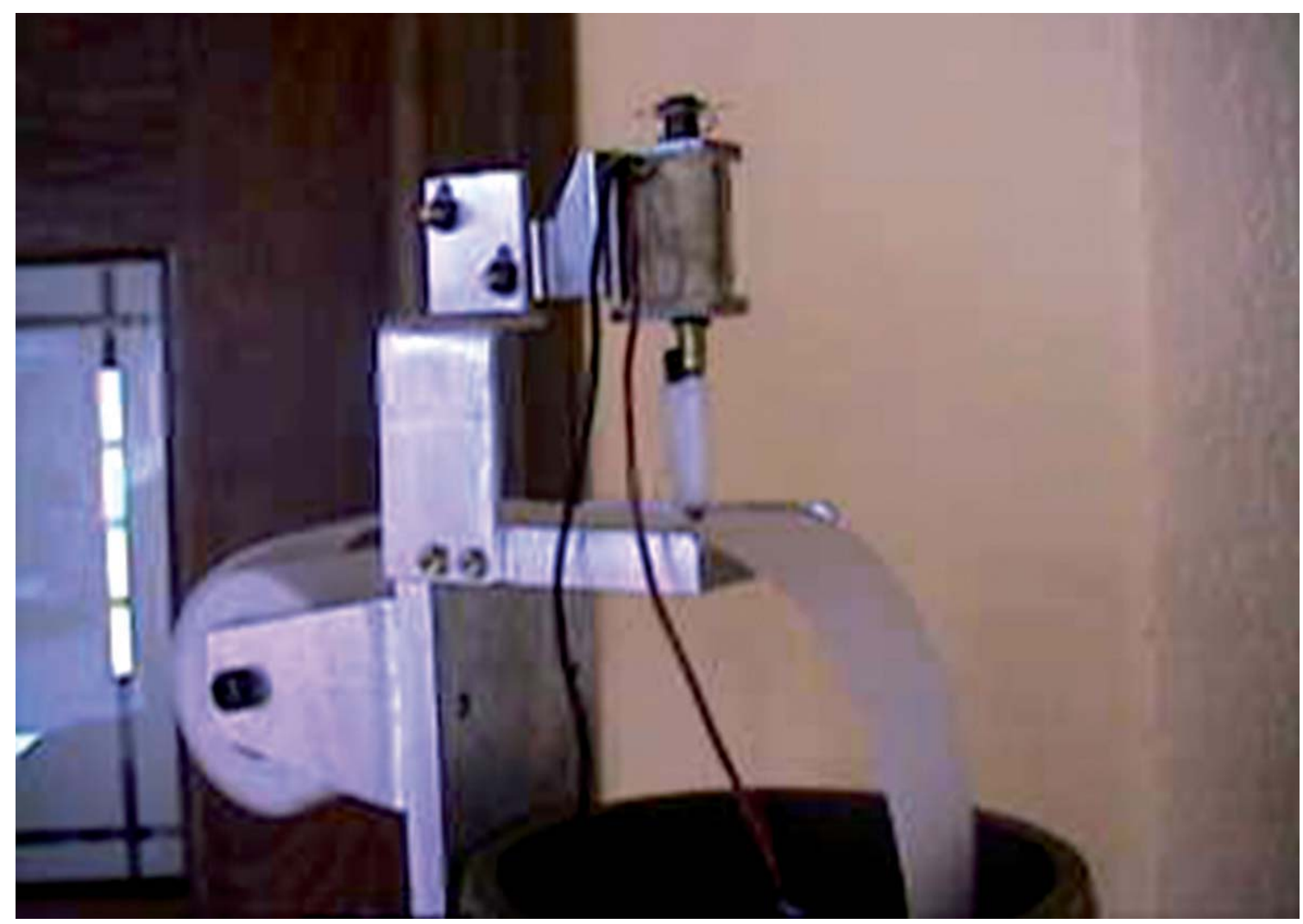

Figura 10 - Fita de papel passando pelo vibrador (marcador de tempo). 


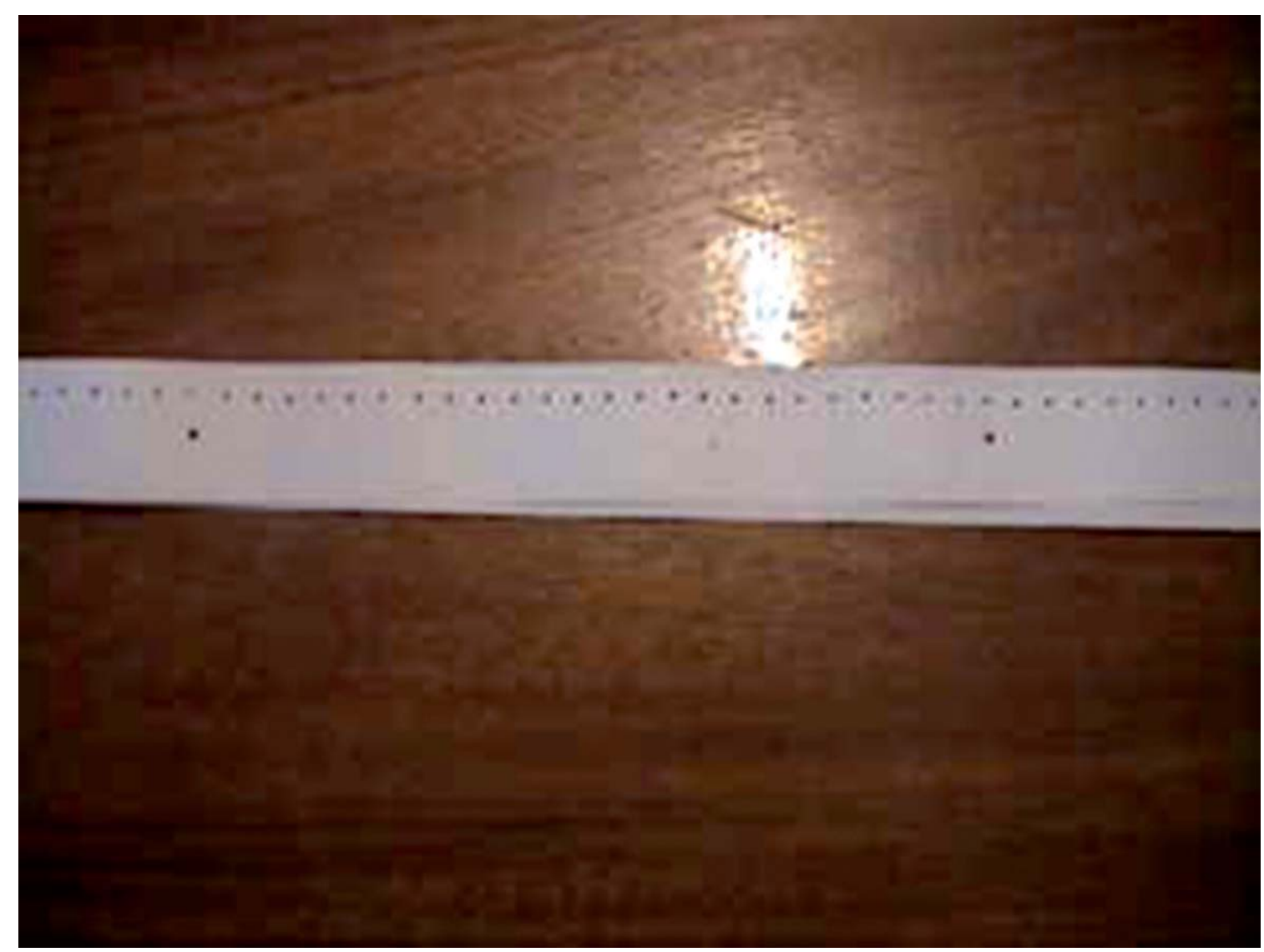

Figura 11 - Fita de papel com as marcas do vibrador.

Para a construção da maquete 6, os seguintes materiais deverão ser utilizados:

1) Tubo de PVC de 1,8 $\mathrm{m}$ de altura com $102 \mathrm{~mm}$ de diâmetro interno.

2) Sensores magnéticos para alarme.

3) Um disco metálico e um imã.

4) Chapa dobrada.

5) Bobina, oscilador e potenciômetro.

6) Rolo de fita de papel para marcador de tempo.

Utilizamos um pedaço de fita de papel de aproximadamente $2 \mathrm{~m}$ de comprimento com marcações em alto relevo de $1 \mathrm{~cm}$. Essas marcações, feitas ao longo de toda fita, têm por objetivo proporcionar ao aluno com deficiência visual as condições para que ele obtenha as distâncias entre os pontos marcados na fita de papel pelo marcador de tempo. Um outro aspecto a ser ressaltado refere-se à utilização da fita de papel solta, e não em forma de rolo. A disposição da fita de papel da maneira citada acima mostrou-se mais eficaz, já que a utilização 
dessa fita na forma de um rolo fazia com que durante a queda do objeto o papel se rompesse, coisa que não ocorreu com a fita solta.

7) Um fio de nylon de aproximadamente $3 \mathrm{~m}$ de comprimento. Esse fio tem por objetivo retirar o disco de dentro do tubo após a queda do disco. Além disso, ele pode ser utilizado para controlar com as mãos, a velocidade de queda do disco e para proporcionar uma percepção tátil da atração gravitacional.

Para montar o equipamento de interface sonora para queda dos objetos, siga os procedimentos listados na sequência:

1) Perfure o tubo de PVC a cada $15 \mathrm{~cm}$ e, nesses furos, coloque os sensores magnéticos para alarme.

2) Coloque o imã junto ao disco. Quando abandonado da extremidade do tubo, o disco desliza dentro deste com um imã, e ao passar pelos sensores, o imã ativa o alarme.

3) No topo do tubo, coloque uma chapa dobrada por onde o papel (fita para marcador de tempo) é alimentado e preso ao disco.

4) No topo da estrutura, coloque também a bobina com um oscilador e um potenciômetro que permitam ajustar a frequência mais adequada de impacto para a agulha que perfura o papel enquanto o disco cai dentro do tubo.

Com esse equipamento, alunos com e sem deficiência visual podem observar auditivamente a queda do objeto dentro do tubo por meio do som emitido pelo alarme e, por meio das marcas deixadas no papel, fazer análises quantitativas.

Para utilizar o equipamento de interface sonora para queda dos objetos, você poderá utilizar os seguintes procedimentos:

1) Separe os alunos em grupos de no máximo três participantes. Cada grupo de alunos deverá realizar o experimento de deixar cair o objeto dentro do tubo, observando assim, de maneira auditiva, a queda do objeto. Aqui existe um espaço para que o professor possa intervir com explicações acerca do fenômeno observado.

2) Em seguida, os grupos com a posse da fita de papel poderão escolher a unidade de tempo (cinco tiques, por exemplo) para a realização de cálculos de velocidade e aceleração. Um tique corresponde ao inter- 
valo de tempo entre duas marcas consecutivas do vibrador na fita de papel.

3) Os grupos deverão numerar a fita de papel com intervalos inteiros de unidade de tempo. Para tanto, o professor ou um colega vidente deverá reforçar, com a ajuda de um instrumento pontiagudo, as marcas escolhidas e deixadas na fita de papel pelo marcador de tempo. Aqui existe uma outra oportunidade de intervenção por parte do professor, já que os alunos estarão observando por meio do tato, as marcas deixadas no papel pelo marcador de tempo.

4) Solicite aos alunos que, com o auxílio das marcas de $1 \mathrm{~cm}$ em relevo, meçam o comprimento de cada intervalo numerado na fita de papel. Intervenção do professor: Esses comprimentos são iguais? Por quê? A diferença entre cada intervalo consecutivo é constante? Qual é o significado físico desses comprimentos? As velocidades em cada intervalo têm o mesmo valor? Por quê?

5) Oriente os alunos para que calculem a variação da velocidade, subtraindo o valor da velocidade média em um intervalo de tempo pelo valor da velocidade média no intervalo anterior. Repita este procedimento em vários intervalos e compare os resultados. Intervenção do professor: A variação da velocidade foi constante?

6) Oriente os alunos para que calculem a aceleração em cada intervalo, dividindo a variação da velocidade pelo intervalo de tempo correspondente a essa variação (cinco tiques).

\section{Conclusões}

Elaboramos um texto que apresenta materiais e métodos adequados a um ambiente de ensino de Física que contemple a presença de alunos com e sem deficiência visual. Os materiais, por proporcionarem referenciais táteis, auditivos e visuais dos fenômenos estudados, criam um canal de comunicação entre docente e discente com deficiência visual, bem como entre discentes com e sem deficiência visual. Dessa forma, a ideia geratriz da elaboração dos materiais pode ser utilizada pelo professor de Física para a construção de outros materiais de ensino para alunos com e sem deficiência visual, ou seja, a inserção, durante a elaboração de um material de ensino de 
Física, de referenciais não visuais para a observação do fenômeno estudado. Por outro lado, a metodologia sugerida no presente texto fundamentase em dar condições para que todos os alunos participem de um ambiente educacional que favoreça a troca de ideias entre os alunos. Esta metodologia busca proporcionar condições para que o ambiente social da sala de aula seja descritivo, argumentativo, questionador e, dessa forma, constitua-se em um contexto de aprendizagem. Em tal contexto, alunos com deficiência visual não representarão anormalidades educacionais, pois as diferenças sensoriais e de formas de pensamento atuarão como um ponto positivo entre os alunos, e não como um fator excludente.

\section{Agradecimentos}

Às instituições: Colégio Técnico Industrial Prof. Isaac Portal Roldán (CTI) e Lar Escola Santa Luzia para Cegos, que abriram suas portas para a realização das investigações educacionais. Estas instituições localizam-se na cidade de Bauru - SP.

Aos formandos do curso de licenciatura em física da Unesp de Bauru do ano de 2005.

À Fundação de Amparo à Pesquisa do Estado de São Paulo (Fapesp) pelo apoio financeiro.

\section{Referências bibliográficas}

ALMEIDA D. R. V.; MACIEL FILHO R. P.; CAMARGO E. P.; NARDI, R. Ensino de Óptica para alunos com deficiência visual: análise de concepções alternativas: In: ENCONTRO NACIONAL DE PESQUISA EM EDUCAÇÃO EM CIÊNCIAS, 5, 2005, Bauru. Atas... Bauru, 26 de novembro a 03 de dezembro de 2005. CD-ROM.

BRASIL, MEC. Parâmetros Curriculares Nacionais, adaptações curriculares, 1998. Disponível em: http://www.educacaoonline.pro.br/adaptacoes_curriculares. asp Acesso em: 10 maio 2005.

Congresso Nacional. Lei no 9.394, de 20/12/1996. Fixa diretrizes e bases da educação nacional. Diário Oficial da República Federativa do Brasil. Brasília, no 248, de 23/12/1996. 
CAMARGO, E. P. Um estudo das concepções alternativas sobre repouso e movimento de pessoas cegas. 2000, 218 p. Dissertação (Mestrado em Educação para a Ciência) - Faculdade de Ciências, campus de Bauru, Universidade Estadual Paulista Júlio de Mesquita Filho, 2000.

O ensino de Física no contexto da deficiência visual: elaboração e condução de atividades de ensino de Física para alunos cegos e com baixa visão. 2005. Tese (Doutorado em Educação). Faculdade de Educação, Universidade Estadual de Campinas, 2005.

A formação de professores de física no contexto das necessidades educacionais especiais de alunos com deficiência visual: o planejamento de atividades de ensino de física. Bauru: Unesp/FC, 2006. (Projeto de pesquisa de pós-doutorado vinculado ao programa de Educação para a Ciência, Área de Concentração: Ensino de Ciências - Processo Fapesp no 04/13339-7 - Faculdade de Ciências, Universidade Estadual Paulista, Bauru).

CARVALHO, E. N. S. Escola integradora: uma alternativa para a integração escolar do aluno portador de necessidades educativas especiais. In: SORIANO, E. M. L. A. Tendências e desafios da educação especial. Brasília: MEC, 1994.

CARVALHO, E. N. S.; MONTE, F.R.F. A educação inclusiva de portadores de deficiências em escolas públicas do DF. Temas em Educação Especial III. São Paulo:Universidade de São Carlos, 1995.

PÉREZ, D. G.; ALÍS, J. C.; DUMAS-CARRÉ, A.; MAS C. F., GALLEGO, R.; DUCH, A. G.; GONZÁLEZ, E.; GUISASOLA, J.; MARTÍNEZ-TORREGROSSA, J.; CARVALHO, A. M. P.; SALINAS, J.; TRICÁRIO, H.; VALDÉS, P. Puede hablarse de consenso constructivista en la educación científica? Enseñanza de la ciencia, v.18, n.1, 1999.

SASSAKI, R. K. Inclusão: construindo uma sociedade para todos, WVA editora, 5. ed., Rio de Janeiro, 1999.

SOLER, M. A. Didáctica multisensorial de las ciencias. Ediciones Paidós Ibérica, S.A, Barcelona, 1999, 237p.

WHEATLEY, G. H. Construtivist Perspectives on Science and Mathematics Learning, Science Education, v.75, n.1, pp.9-21, 1991. 


\title{
8 \\ O ENSINO de CiÊnCIAS e seus desafios PARA A INCLUSÃO: O PAPEL DO PROFESSOR ESPECIALISTA
}

\author{
Eliza Márcia Oliveira Lippe ${ }^{1}$ \\ Eder Pires de Camargo ${ }^{2}$
}

\section{Introdução}

As abordagens relacionadas ao contexto educacional inclusivo têm diante de si um desafio para encontrar soluções que possam responder sobre o acesso e permanência dos alunos com necessidades educacionais especiais presentes na rede pública de ensino.

Neste sentido, encontra-se a escola da racionalidade dividida em modalidades de ensino. Entretanto, ao assumir a postura de romper com as bases de uma estrutura educacional, como está evidenciado no contexto inclusivo, podemos encontrar a saída para que a escola possa espalhar sua ação formadora por todos os que dela participam (Mantoan, 2003).

Nesse cenário, para que aconteça a efetiva inclusão, o atual paradigma educacional pretenderá (re)traçar o novo mapa da educação escolar, fazendo com que toda a escola se engaje nessa nova etapa, desenvolvendo um projeto político pedagógico que envolva esses alunos, tendo instrumental didático, esclarecimento sobre as necessidades educacionais especiais do aluno, entre muitas outras coisas

Para tanto, os educadores devem buscar diferentes estratégias de ensino em suas áreas de atuação disciplinar, visando ampliar a magnitude de tal

1 Mestranda do Programa de Pós-Graduação em Educação para a Ciência, Faculdade de Ciências, campus de Bauru, Universidade Estadual Paulista Júlio de Mesquita Filho (Unesp). Grupo de Pesquisa em Ensino de Ciências.

2 Docente do Programa de Pós-Graduação em Educação para a Ciência, campus de Bauru, Universidade Estadual Paulista Júlio de Mesquita Filho (Unesp). 
ensino, o que conduziria ao rompimento do paradigma tradicional que rege o ensino de um modo geral. Os alunos, por sua vez, precisam estar inseridos em um ambiente no qual a compreensão dos trâmites existentes entre a construção do saber seja favorecida.

No entanto, verifica-se a inexistência de discussões a respeito da necessidade dos docentes em lidar com essa nova questão em sala de aula. No geral, os docentes acabam por homogeneizar os alunos involuntariamente apenas por não conhecer a necessidade educacional do seu aluno, provocando muitas vezes prejuízo ao seu aprendizado.

Por todos esses agravantes e muitos outros é que se faz de essencial importância a presença de um professor especialista no contexto escolar, orientando e ajudando tanto os alunos com necessidades educacionais especiais quanto os seus professores, para que a inclusão não fique apenas na teoria e possa ser efetivamente praticada de forma eficaz e não discriminatória, como acontece dentro da maioria das escolas que possuem sala de recursos multifuncionais.

A Educação Especial tem passado, no Brasil, por um momento novo, no qual se faz uma reflexão sobre a educação inclusiva. Isto se deve às novas leis implantadas e às mudanças de atitude sociais que vêm se estabelecendo ao longo do tempo.

Atualmente, o professor de sala comum possui a maior responsabilidade de educar o aluno com deficiência visual. Ao professor da sala de recurso cabe orientá-los sempre que necessitarem e complementar essa educação. Dentro dessas orientações cabem algumas em específico. Destacamos (Brasil, 1994f):

A maior questão que os docentes expõem quando questionados a respeito da inclusão é com relação à flexibilidade do ensino ao aluno deficiente visual. Pois toda a organização, a disponibilidade de materiais, a orientação dos pais e informações sobre o tipo de tratamento e a evolução que estão sendo oferecidos aos seus filhos devem ser dados pelo professor especialista.

À medida que se percebe que vai atingindo domínio das técnicas de escrita e leitura, independência social e acadêmica, vai-se diminuindo gradativamente a permanência desse aluno nessa sala. (Herrero, 2000)

Para tanto, discutimos, no contexto do Ensino de Ciências, pontos de convergência a um ensino coerente com uma proposta inclusiva de construção do saber que lança mão de estratégias abrangentes nas quais os saberes dos alunos sejam valorizados em meio à diversidade presente nas escolas. 
Além disso, considerando que incluir transcende uma integração por meios físicos, ou seja, incluir é, sobretudo, disponibilizar aos alunos a possibilidade de dominar um saber real (e não transitório), destacamos o modo excludente e inacessível com que a Ciência, muitas vezes, tem sido tratada em sala de aula. Esperamos que essa discussão subsidie a proposição de possíveis caminhos para uma mudança de postura assumida até então e que norteia o ensino tradicional dessa disciplina.

Existem muitos obstáculos que impedem que a política de inclusão aconteça plenamente em nosso cotidiano. Entre estes, a principal, sem dúvida, é o despreparo dos professores do ensino regular para permitir que ral inclusão aconteça em suas salas de aulas, geralmente repletas de alunos com os mais variados problemas sociais, disciplinares e aprendizagens (Bueno, 1999; Glat, 2007).

Bueno (1999) nos fala que para que o ensino seja de qualidade para os portadores de necessidades educativas especiais, na perspectiva de uma educação inclusiva, há muitos aspectos envolvidos, entre eles os dois tipos de docentes: professores "generalistas" do ensino regular, com o mínimo de conhecimento e prática sobre os mais variados alunos e professores; "especialistas" nas diferentes "necessidades educativas especiais", seja para trabalhar direto com os alunos, seja para dar apoio ao trabalho realizado por professores de classes regulares que integrem esses alunos.

O professor, agindo de acordo com a formação recebida, costuma privilegiar certos documentos em detrimentos de outros. Dessa forma, o saber pode se apresentar em um circuito repetitivo desvinculado da realidade do aluno, o que faz com que o sujeito mantenha uma prática alienada de sua realidade.

É o que tem acontecido com a maioria de nossos professores, sejam eles "regulares" ou "especiais". No entanto, é importante ressaltar que eles agem dessa forma em parte por não terem recebido, em seus cursos de formação e capacitação, suficiente embasamento que lhes possibilite estruturar sua própria prática pedagógica para atender às distintas formas de aprendizagem do alunado.

Em consequência, não é de se surpreender que ainda não tenha havido uma efetiva integração e inclusão de alunos com necessidades educacionais especiais no sistema regular de ensino. O professor, no contexto de uma educação inclusiva, precisa, muito mais do que no passado, ser capacitado 
para lidar com as diferenças, com as singularidades e a diversidade de todas as crianças, e não com um modelo de pensamento comum a todas elas.

A validade da educação inclusiva, no entanto, é indiscutível, se considerarmos que a criança interage com o meio, considerando-se sua maneira própria, diferente de entrar em contato com o mundo, respeitando sempre suas possibilidades e limites. Para Sassaki (1997), inclusão é "um processo pelo qual a sociedade se adapta para poder incluir, em seus sistemas sociais gerais, pessoas com necessidades especiais e, simultaneamente, estas se preparam para assumir seus papéis na sociedade" (p.41). O ensino, revendo esta frase, deve se adaptar às necessidades dos alunos, ao invés de ser ao contrário, ou seja, o aluno adaptar-se aos paradigmas preconcebidos a respeito do ritmo e da natureza e dos processos de aprendizagens.

Como já dissemos, o ensino regular tem excluído, sistematicamente, larga escala da população escolar sob a justificativa de que esse alunado não reúne condições para usufruir o processo de escolarização por apresentar problemas de diversas ordens, ou, como podemos nos orientar pelas palavras de Coll, Palácios \& Marchesi (1995, p.11), "por apresentarem algum tipo de aprendizagem ao longo de sua escolarização, que exige uma atenção mais específica e maiores recursos educacionais do que os necessários para os colegas de sua idade".

Desse modo, Fonseca (1995) acredita que é preciso preparar todos os professores, com urgência, para se obter sucesso na inclusão, por meio de um processo de inserção progressiva. Porém, os professores só poderão adotar essa postura se forem adequadamente equipados, se sua formação for melhorada, se lhes forem dados meios de avaliar seus alunos e elaborar objetivos pedagógicos e podendo contar com uma orientação eficiente nessa mudança de postura para buscar novas aquisições e competências.

Olhando para os cursos que formam professores que irão atuar com a Educação Infantil e o Ensino Fundamental e com as séries iniciais, não se observa uma grande preocupação com relação à construção do conhecimento à educação e do ensino. Falta o costume de se pesquisar sobre o trabalho escolar.

Esses cursos, em sua maioria, priorizam a visão sobre o ensino regular voltado para as crianças que não possuem deficiência, deixando de lado outros tipos de educação, tais como: educação de jovens e adultos, educação de portadores de necessidades especiais e educação indígena, tão importantes 
quanto a mencionada acima. Os docentes que estão sendo formados não estão sendo preparados para lidar com as diferenças, sejam elas culturais ou éticas, situação essa que tem preocupado algumas entidades, ONGs e familiares.

Em geral, os profissionais têm esperança que os professores de Educação Especial primeiro se familiarizem tanto teoricamente quanto em termos de experiência com a criança e o jovem sem deficiência física e intelectual. É difícil, se não impossível, compreender a criança com deficiência intelectual sem ter uma boa perspectiva da criança sem deficiência (Cruickshankem, 1993, apud Capellini, 2001, p.43).

Os graus de conhecimento que deverão se exigir do professor variam de acordo com o tipo de público que ele irá trabalhar. Além disso, alguns especialistas recomendam que esses profissionais especializados não entendam somente da área que irão atuar, mas saibam pelo menos um pouco das demais áreas também. Exemplo: o professor especialista em deficiência visual, é interessante que ele saiba também de deficiência auditiva, de deficiência intelectual, e assim sucessivamente.

Segundo Jerome Rothstein (1960, apud Capellini, 2001, p.39), "pode parecer cruel, mas a verdade é que um professor incompetente ou mal preparado para a tarefa acarretará à criança retardada mental maior mal que a ausência de recursos de educação especial”.

Considerando os pressupostos destacados anteriormente, este trabalho procura analisar a real situação em que se encontra o docente especialista em deficiência visual da Diretoria de Bauru, seu envolvimento com os pressupostos teóricos e práticos atuais que regem o processo educativo referente aos alunos com necessidades educacionais especiais e qual seu papel frente ao processo de inclusão escolar, além de levantar os empecilhos enfrentados por esses docentes e que tipo de formação continuada vêm recebendo.

\section{Metodologia}

A coleta de dados se deu por meio de entrevista semiestruturada com a professora especialista em deficiência visual da sala de recursos presente em uma escola do município de Bauru (SP), de cunho fenomenológico, a qual foi transcrita integralmente e submetida a uma análise qualitativa. A opção por métodos qualitativos se deu pelo fato de trabalharmos com uma reali- 
dade que não pode ser facilmente quantificada, mas que possui significados e intencionalidade para os sujeitos consultados (Bogdan \& Biklen, 1994).

Contamos também com a abordagem fenomenológica, de acordo com os autores Bicudo (1997), Martins (1992) Husserl, Heidegger ou MerleauPonty (2006). Em conjunto a tais referências, contamos com orientações de pessoas e de trabalhos desenvolvidos sob a perspectiva fenomenológica e seguimos de perto seus passos, compreendendo suas motivações e seus modos de ação. Por esse motivo, inscrevemos nossa abordagem metodológica como "de inspiração fenomenológica", pois isso nos parece mais adequado, mais sincero, mais possível.

Segundo Bardin, a análise de conteúdo se constitui em três partes: a préanálise, a exploração do material e o tratamento dos resultados, a inferência e interpretação.

A pré-análise consiste em organizar e sistematizar ideias “... de maneira a conduzir a um esquema preciso do desenvolvimento das operações sucessivas, num plano de análise" (Bardin, 1977, p.95). Essa etapa foi realizada com a escolha da docente especialista a ser entrevistada, tendo sempre como foco a relação dos professores com a deficiência visual.

Ainda de acordo com Bardin, a codificação é um processo de transformação dos "dados brutos" em uma real representação do conteúdo, por meio de agregação (Bardin, 1977, p.103). A categorização complementa esse processo, uma vez que as categorias emergem dessa codificação.

O tratamento dos resultados foi feito por meio da elaboração das categorias e sistematização das falas da docente especialista

\section{Resultados e discussão}

Como citado anteriormente, o foco deste trabalho foi analisar a situação em que se encontra o professor especialista em deficiência visual presente em uma escola estadual no município de Bauru.

Assim, uma primeira constatação interessante é que não há um planejamento para as atividades diárias com os alunos deficientes visuais. Tal situação é refletida posteriormente na sala de aula regular, pois se observa que com essa falta de planejamento, os alunos deficientes acabam por apenas no período em que está na sala de recursos, realizar as atividades, ou de tarefa 
ou da classe (período contrário), portanto, esse local acaba tornando-se um local de reforço acadêmico ou não de apoio, como consta na legislação.

Quando se questiona os professores da sala de aula comum com relação as funções da sala de recursos multifuncionais, em seus discursos eles afirmam que a sala de recursos é o local de apoio pedagógico ao professor da sala comum, entretanto, a sua prática não condiz com seu discurso na medida em que ele apenas, na maioria das vezes, solicita ao aluno que realize suas atividades de classe e tarefas na sala de recursos.

Realizada essa primeira observação, passemos a um detalhamento de alguns resultados.

No município em questão, consta a presença de 28 alunos com deficiência visual matriculados na rede pública de ensino em diversos níveis de escolaridade, sendo que a maioria encontra-se no Ensino Fundamental I (1ํa a $4^{\underline{a}}$ série). Para tanto, nesse município há uma carência de profissional especialista nessa área de atuação, contando com apenas duas professoras, que se revezam em turnos para assessorar esses alunos nas atividades didático-pedagógicas, elaboração de materiais e transcrição das atividades de classe para o braile.

Há seis máquinas braile da escola em questão que estão no conserto em São Paulo devido a má utilização do equipamento pelos alunos deficientes. Com isso, os alunos preferem utilizar em seu dia a dia a reglete.

Em decorrência da presença dos alunos com deficiência na sala de recursos multifuncional por aproximadamente duas horas, com frequência de dois dias da semana, eles acabam por adquirir um envolvimento com as professoras especialistas presentes na sala, visto que o processo de alfabetização escolar inicia por volta dos 6 anos de idade, fase em que iniciam os trabalhos na sala de recursos, fazendo com que exista por parte das docentes uma preocupação com as ausências injustificadas dos alunos.

De acordo com Bandura (2005), essa questão de afetividade que é adquirida com o passar do tempo do aluno com deficiência na sala de recursos, demonstra que o papel do professor acaba sendo de apoio didático-pedagógico, ou seja, os alunos deficientes muitas vezes preferem esclarecer suas dúvidas e aflições com as professoras especialistas do que com os professores da sala de aula comum. Com isso, a relação afetiva entre os alunos deficientes e as professoras da sala de recursos acaba tornando-se fragilizada com o tempo, como exemplificado na fala transcrita: "[... e e aí eu falo 
todo dia pra mim: 'Eu não vô me estressá! Eu não vô me estressá!' Porque, sabe, a gente se envolve, a gente se preocupa" (fala da professora da sala de recursos).

Como destaca Bicudo (1997), em outro momento a professora relata que o trabalhar com esse público no ensino tem que acontecer pelo gostar do ofício de professor, pois sem essa motivação, o trabalho torna-se um fardo na vida desse profissional, como evidenciado na fala da docente especialista: "Porque, olha, pra gente trabalhá aqui, a gente tem que gostar mesmo. E eu não me vejo trabalhando em outro lugar a não ser nisso... Só que aqui a gente fica amarrada, não tem como fazer".

Neste caso, a professora sente-se feliz ao ver-se trabalhando com os alunos. Entretanto, a motivação extrínseca que está ocorrendo no dia a dia do trabalho acaba por limitar a ação docente, que se decepciona subordinado a regras de um sistema educacional que impõe ao professor como ele deve atuar em sala com seus alunos (Pajares, 1996): “[...] mas a gente não tem como deixá de se envolver. A gente tem um fofo na educação especial, mas a gente tem que chegá até um certo limite, né?”.

Constata-se que arande maioria dos professores especialistas percebeesse limiar de envolvimento que tem que existir no trabalho escolar. Mas talvez a maior dificuldade dos professores seja trabalhar com a questão da frustração da família, que infelizmente, na maioria dos casos, demora a aceitar a deficiência do filho, como aconteceu com os dois casos analisados na dissertação.

Quando a professora foi questionada com relação ao que ela entende por ser sala de recursos, há a concepção dela que tem recursos pedagógicos e que tem a função de apoio. Entretanto, a dificuldade encontra-se em saber exatamente qual é o seu papel, visto que ela deveria trabalhar em conjunto com os professores da sala regular, o que muitas vezes não acontece pela falta de interesse por parte dos professores da sala comum na temática da educação especial, falta de tempo para o estudo relacionado à inclusão, falta de capacitação adequada para atuar com esses alunos e principalmente a falta de discussão deste tema nos cursos de licenciatura, entre outros fatores.

Observa-se que na Lei no 9394/96 (Brasil, 1996), existe um item que menciona a necessidade de capacitar os professores, principalmente os presentes na rede pública, pela responsabilidade que têm em relação ao trabalho desenvolvido com a maioria das crianças e adolescentes em idade escolar. Algumas questões são de fundamental importância, a ser abordadas na 
capacitação. Sendo que esta teria que abordar questões voltadas tanto para o melhor convívio e entendimento com esses alunos com necessidades educacionais especiais quanto aos seus processos de aprendizagem e necessidades adaptativas. Contudo, o que se percebe é que para essa mudança ocorrer, torna-se necessário ir muito além de simples capacitações e especializações de caráter informativo para os professores lidarem com essa população.

A fragmentação está presente com relação à articulação entre as disciplinas contempladas no currículo tradicional. Essa fragmentação acompanha os cursos de formação no que diz respeito à formação geral e específica, à teoria e prática e à formação permanente do professor durante sua vida profissional.

Neste sentido, verifica-se que, segundo a especialista, quando há alguns cursos disponíveis na área da educação inclusiva, poucos professores se interessam, como se observa na fala: "[...] quando tem alguma coisa que aparece, tipo assim no final de semana [...] não tem ninguém que se interessa [...] é bem poucos assim os que querem, aí a gente faz uma orientação pra eles antes de começarem."

Já com relação à nova política do governo do Estado de São Paulo, observa-se, de acordo com o relato da professora, que as capacitações presenciais estão sendo ofertadas apenas para os coordenadores da Educação Especial das secretarias e/ou diretorias de ensino, que ficam responsáveis por repassar as informações aos professores especialistas, o que infelizmente não tem ocorrido com a frequência que é desejada.

Finalmente, relacionado ao material pedagógico enviado às escolas estaduais para orientar o professor em sua prática da sala de aula, observa-se que, apesar de ser apostilado, há uma boa coerência na estrutura em que foi elaborado. Entretanto, a dificuldade é o material para deficientes visuais, pois não foi distribuído aos alunos o material em braile, que seria de grande importância para os alunos conseguirem, provavelmente, obter maior êxito em sua aprendizagem.

\section{Considerações finais}

Apresentamos aqui uma breve síntese dos resultados discutidos ao longo do artigo. Em primeiro lugar, os dados mostram que o professor especialista, infelizmente, pelo excesso de atividade em sua jornada diária, acaba 
por, às vezes, negligenciar o processo educativo com os alunos, consentindo que muitas vezes aconteça o reforço e não o apoio pedagógico necessário para auxiliar os alunos.

Foram encontrados durante a pesquisa diversos fatores que concretizam o papel do professor especialista na sala de recursos multifuncional. Alguns deles se ligam a problemas mais gerais da sociedade e da educação, como, por exemplo, a situação encontrada nas escolas de educação básica com a presença dos alunos deficientes, que muitas vezes não são incluídos na sala de aula e sim apenas inseridos na sala de aula, o que significa que os professores especialistas têm por função dar todo o suporte necessário aos professores da sala de aula comum.

Neste caso, a dificuldade está na articulação entre os docentes, visto que o professor da sala regular muitas vezes encontra-se com a carga horária de trabalho elevada e com pouco tempo para dedicar-se a esses alunos e a adequações curriculares necessárias para a melhor aprendizagem dos alunos.

Não obstante tais problemas, a questão do envolvimento afetivo entre o especialista e o aluno tende a aumentar com a frequência dos alunos na sala de recursos, diferentemente com o que acontece com a relação familiar, que é inversamente proporcional à frequência do aluno na sala, pois com isso, os professores especialistas começam a "sofrer" com os alunos e com as dificuldades das famílias.

Finalmente, apontado na fala da professora, o trabalho com os deficientes tem de ser realizado com prazer, ou seja, ele tem de sentir-se bem à vontade não só com relação ao conteúdo pedagógico a ser ensinado como também com as relações que vão sendo criadas e que aos poucos acabam sendo fragilizadas com o tempo.

\section{Referências bibliográficas}

BANDURA, A. Self-efficacy: The evolution of social cognitive theory. In: K. G. S.; M. A. H. (Eds.). Great Minds in Management: Oxford Univertsity Press, pp.9-35, 2005.

BARDIN, L. Análise de conteúdo. Lisboa: Edições 70, 2000.

BICUDO, M. A. V. A contribuição da fenomenologia à educação. IN: COÊLHO, I. M.; GARNICA, A. V. M. Fenomenologia: uma visão emergente da Educação. Olho d'Água Editora, São Paulo-SP, pp.11-53, 1999. 
BOGDAN, R.; BIKLEN, S. Investigação qualitativa em educação: uma introdução à teoria e aos métodos. Porto: Porto Editora, 1994.

BRASIL (MEC) - Secretaria de Educação Especial. Subsídios para organização e funcionamento dos serviços de educação especial: Área de deficiência visual. Série: Diretrizes 8, $1994 \mathrm{f}$.

BRASIL. Lei no 9394, 23 de dezembro de 1996. Lei de Diretrizes e Bases da Educação Nacional. Brasília: Ministério da Educação e do Desporto, 1996.

BUENO, J. G. da S. Crianças com necessidades educativas especiais, políticas públicas e a formação de professores: generalistas ou especialistas? Revista Brasileira da Educação Especial, v.3, n.5, pp.7-25, 1999.

CAPELLINI, V. L. M. F. A inclusão dos alunos com necessidades educacionais especiais em classes comuns: avaliação do rendimento acadêmico. Dissertação (Mestrado). Universidade Federal de São Carlos (UFSCar), São Paulo, 2001.

COLL, C.; PALACIOS, J.; MARCHESI, A. Desenvolvimento Psicológico e Educação: necessidades educativas especiais, Porto Alegre: Artes Médicas, v.3, 1995.

CRUICKSHANKEM, W. M.; JOHNSON, G. O. A Educação da criança e do jovem excepcional. Porto Alegre: Globo, 1974. DOE de 10 de janeiro de 2001.

FONSECA, V. Educação Especial: Programa de Estimulação Precoce - Uma introdução às ideias de Fuerstein. Porto Alegre: 2. ed., -Ed. Artes Médicas, 1995.

GLAT, R. Educação inclusiva: cultura e cotidiano escolar. Rio de Janeiro: 7 Letras, 2007. (Questões atuais em Educação Especial IV)

HERRERO, M. J. P. Educação de alunos com necessidades especiais: bases psicológicas: caderno de atividades. Tradução Maria Helena Maurão Alves Oliveira, Marisa Bueno Mendes Gargantini, EDUSC, Bauru-SP, 2000.

MANTOAN, M. T. E. A integração de pessoas com deficiência. São Paulo: Memnon: Editora SENAC, pp.137-141, 1997.

MARTINS, J. Um enfoque fenomenológico do currículo: educação como poíesis/ Joel Martins; (Org.) do texto Vitória Helena Cunha Espósito. São Paulo: Cortez, 1992.

MERLEAU-PONTY, M. Fenomenologia da percepção. 3. ed. São Paulo: Martins Fontes, 2006.

PAJARES, F. Self-efficacy beliefs in academic settings. Review of Educational Research, v.66, n.4, pp.543-578, 1996

SASSAKI, R. K. Inclusão da pessoa com deficiência no mercado de trabalho. São Paulo: PRODEF, 1997, 16 p. 



\title{
9 \\ DIFICULDADES DOS PROFESSORES EM INTRODUZIR a Física Moderna no Ensino MÉdio: A NECESSIDADE DE SUPERAÇÃO DA RACIONALIDADE TÉCNICA NOS PROCESSOS FORMATIVOS
}

\author{
Maria Amélia Monteiro ${ }^{1}$ \\ Roberto Nardi ${ }^{2}$ \\ Jenner Barretto Bastos Filho ${ }^{3}$
}

\section{Introdução}

Constata-se na literatura um crescente número de pesquisas contemplando o ensino da Física Moderna e Contemporânea (FMC) (Ostermann e Moreira, 2000; Greca e Moreira, 2001).

Algumas justificativas são apresentadas em defesa da introdução da FMC na educação básica. Dentre elas, que facilita a aprendizagem subsequente da FMC; a possibilidade dos estudantes desenvolverem um entusiasmo mais duradouro pela Ciência; a necessidade de que a FMC seja tratada como um elemento cultural (Shabajee e Postlethwaite, 2000). Com o intento de que toda a Física faça parte da formação cultural dos estudantes, Carvalho e Zanetic (2004) defendem que a introdução da FMC na educação básica deverá ocorrer em articulação com a arte. Dentre outras possibilidades, o ensino de Física articulado com várias áreas do conhecimento favoreceria uma educação "problematizadora" e em sintonia com questões sociais mais amplas (Zanetic, 2005). Entretanto, diante da fre-

1 Doutoranda do Programa de Pós-Graduação em Educação para a Ciência. Grupo de Pesquisa em Ensino de Ciências. Faculdade de Ciências, campus de Bauru, Universidade Estadual Paulista Júlio de Mesquita Filho (Unesp).

2 Docente do Departamento de Educação e do Programa de Pós-Graduação em Educação para a Ciência. Grupo de Pesquisa em Ensino de Ciências. Faculdade de Ciências, campus de Bauru, Universidade Estadual Paulista Júlio de Mesquita Filho (Unesp).

3 Instituto de Física, Universidade Federal de Alagoas. 
quente diminuição das horas-aulas de Física e da forma adotada para as atribuições de aulas pela Secretaria da Educação do Estado de São Paulo, Zanetic (2006) argumenta que no início do século XX tem defendido uma postura bem mais urgente em relação ao ensino de Física. O autor assinala: "[...] eu diria que precisamos colocar a física de qualquer século na sala de aula antes que ela (a física na escola) acabe!” (p.41).

Já em 1987, Gil Pérez et al. defendiam que a FMC na educação básica poderia contribuir para os alunos adquirirem uma visão da Física articulada com uma perspectiva mais coerente acerca da natureza do trabalho científico, principalmente superando a visão linear e cumulativa incorporada a ele. Valadares e Moreira (1998) mencionam que, quando se trabalha com estudantes do Ensino Médio em uma perspectiva de vir a despertar o interesse para aspectos do cotidiano, a ausência de fundamentos acerca da FMC mostra-se como um grande obstáculo. Logo, argumentam em defesa de a FMC ser incorporada às propostas curriculares do Nível Médio da educação básica brasileira.

Apesar das várias sugestões para se introduzir o ensino de tópicos da FMC na educação básica, é também consenso que ainda se necessita de muitas pesquisas em relação às abordagens e enfoques a serem desenvolvidos, principalmente perante as dificuldades apresentadas pelos professores, conforme comentam Solbes et al. (2001).

Apesar das sugestões acima, no contexto brasileiro a introdução da FMC nas salas de aula parece não se alinhar às mesmas expectativas, apesar de evidências do crescimento de pesquisas na área (Monteiro e Nardi, 2007). Pesquisa realizada por Machado e Nardi (2003) junto a 24 professores de Física, dos 39 que trabalham em escolas públicas de um município da Região Sul do Brasil, evidencia que apenas 29\% deles frequentemente abordavam a FMC em salas de aula. Pesquisa semelhante foi realizada por Oliveira et al. (2007). Os autores ouviram as opiniões de dez professores de Física atuantes em um município da Região Sudeste do Brasil e, apesar de eles mostrarem-se favoráveis à introdução da FMC na educação básica, apenas três deles haviam abordado esporadicamente tópicos de FMC em suas aulas.

Diante das várias proposições para que a FMC seja introduzida na educação básica, como também a partir da constatação de que alguns grupos de professores brasileiros não sendo influenciados pela proposta, apesar de denotarem um certo entusiasmo em relação a ela, na presente pesquisa analisaremos os discursos de um grupo de professores de Física de um mu- 
nicípio da Região Nordeste brasileira no tocante à mencionada proposta. Constatamos que nenhum deles contempla a FMC em suas aulas, apesar de acolherem a proposição. Assim, investigamos os impedimentos para os professores desempenharem o mencionado propósito. Investigamos ainda em que medida esses impedimentos encontram-se relacionados com o perfil de racionalidade subjacente às respectivas formações profissionais.

\section{A pesquisa: aspectos metodológicos}

Para a construção do corpus da presente pesquisa, transformamos em discursos as falas que foram produzidas a partir de entrevistas realizadas com cinco professores de Física do Nível Médio. Para preservarmos a identidade dos professores, serão aqui nomeados de $\mathrm{P}_{1}, \mathrm{P}_{2}, \mathrm{P}_{3}, \mathrm{P}_{4}$ e $\mathrm{P}_{5}$, respectivamente, seguindo a ordem da realização das entrevistas. Acerca do quantitativo de entrevistas, nos fundamentamos em Gaskel (2003), para o qual, quando as questões de pesquisa propostas pelo investigador são respondidas, não se faz necessário entrevistas adicionais.

As entrevistas foram construídas e interpretadas a partir dos referenciais da análise do discurso da escola francesa, bem como de refêrencias da teoria crítica educacional e pelos referenciais da Física Moderna, notadamente da teoria quântica. Devido aos limites de espaço, esses referenciais serão aclarados à medida que procedermos com as análises.

Um dos critérios adotados para os professores participarem foi o de que tivessem concluído o curso de Física, na modalidade licenciatura.

Outro critério adotado para os professores participarem da pesquisa foi o de que tivessem concluído a sua formação a menos de cinco anos. Pressupúnhamos assim que as pesquisas sobre o ensino da FMC tivessem deixado marcas nos discursos dos respectivos professores. Em consonância, todos os professores entrevistados haviam concluído o curso a menos de três anos em uma universidade pública localizada em um Estado da Região Nordeste do Brasil.

Em relação às entrevistas, optamos pelas semipadronizadas. Segundo Ludke e André (1988), quando essa modalidade de entrevista é realizada no contexto educacional, possibilita uma quebra na hierarquia entre entrevistador e entrevistado. No entendimento de Flick (2004), uma das vantagens 
das entrevistas semipadronizadas é a possibilidade de que o entrevistado apresente subjetividades, as quais poderão ser exploradas na interação com o entrevistador.

As entrevistas foram conduzidas visando aclarar as questões de pesquisa mencionadas, como algumas outras que fazem parte de uma pesquisa maior. No entanto, as questões desdobraram-se em várias outras, muitas vezes tendo como guia as respostas apresentadas pelos professores. Neste sentido, os professores responderam alguns focos de questionamentos distintos.

Para a realização das entrevistas e a transformação em discursos, bem como para a posterior interpretação, utilizamos como referencial teórico-metodológico a análise de discurso da escola francesa $(\mathrm{AD})$, originalmente organizada por Pêcheux e seguidores. Utilizamos ainda autores que se fundamentam em teorias críticas, tais como Freire, Habermas e outros. Esses referenciais estão sendo mencionados no texto à medida que interpretamos os discursos dos futuros professores de Física.

Fizemos recortes nos textos produzidos a partir das entrevistas, para atendermos especificações das questões de pesquisa.

Tendo em vista que os objetivos da pesquisa contemplam os processos formativos dos professores e não apenas os resultados, avaliamos que se trata de uma pesquisa qualitativa, conforme descrevem Bogdan e Biklen (1994). Tendo em vista as especificidades do grupo de professores participantes - mesmo curso e atuação, mesma época e universidade -, bem como pelos objetivos, avaliamos que a presente pesquisa segue os contornos do estudo de caso (Goldeberg, 1997).

As entrevistas foram transcritas e registradas integralmente. Gil (2003) alerta que a transcrição de uma entrevista nunca deverá sintetizar a fala, tampouco ser corrigida. A autora considera que essa fidelidade é imprescindível, caso não se queira perder características centrais da fala. Em nossos propósitos, com o intento de transformar a fala em discurso.

\section{Os lugares sociais ocupados pelos professores: 0 contexto da produção dos discursos}

Na matriz curricular da licenciatura em Física cursada pelos licenciandos que participaram da presente investigação, existem duas componentes 
curriculares obrigatórias contemplando a FMC: Física Moderna e Estrutura da Matéria, com sessenta e 65 horas-aula, respectivamente.

Além das componentes curriculares obrigatórias, os professores cursaram componentes curriculares optativas que contemplavam a Física Moderna em outra universidade (B). Os professores $\mathrm{P}_{1}$ e $\mathrm{P}_{2}$ cursaram Estrutura da Matéria I e II, cujas programações se assemelhavam às componentes obrigatórias, Física Moderna e Estrutura da Matéria. Os professores $\mathrm{P}_{1}$ e $\mathrm{P}_{2}$ também cursaram na universidade $\mathrm{B}$ as componentes curriculares Física Matemática e Mecânica Quântica, ambas com carga horária de 60 horas-aula.

Os professores $\mathrm{P}_{1}$ e $\mathrm{P}_{2}$, cursaram em outra universidade Estrutura da Matéria I e II, as quais, em termos de programação, assemelhavam-se às componentes curriculares Física Moderna e Estrutura da Matéria, oferecidas pela universidade em que esses professores eram alunos regulares. Os professores $\mathrm{P}_{1}$ e $\mathrm{P}_{2}$ também cursaram na universidade $\mathrm{B}$, Física Matemática e Mecânica Quântica, ambas com carga horária de 60 horas-aula.

Acrescentamos que mesmo antes da conclusão da formação básica, três dos cinco professores entrevistados $\left(\mathrm{P}_{3}, \mathrm{P}_{4}\right.$ e $\left.\mathrm{P}_{5}\right)$ já atuavam como professores de Física e de Ciências no vível fundamental.

\section{Os impedimentos para os professores introduzirem a FMC na educação básica}

Interpretamos nos discursos de todos os professores que estes atribuem relevância ao ensino da FMC na educação básica. No entanto, a mencionada Física não é contemplada em nenhum dos planejamentos de ensino. Logo, há um descompasso entre as proposições dos pesquisadores que defendem que a FMC seja introduzida na educação básica, a exemplo de Gil et al. (1987), Valadares e Moreira (1998) e vários outros, e as possibilidades dos professores entrevistados.

Quais seriam os impedimentos para os professores não incluírem a FMC em seus planejamentos de ensino, haja vista que eles consideram a mencionada proposição relevante? Na presente seção, focamos a interpretação dos discursos que fornecem algumas pistas.

O professor $\mathrm{P}_{1}$, por exemplo, alegou o reduzido tempo disponibilizado às aulas de Física. Menciona: "Temos muitos conteúdos e pouco tempo. 
[...] Não vejo como fazer isso. [...] São duas aulas por semana... Ai não é possível trabalhar a Física Moderna, porque nem terminamos a programação completa da Física Clássica. [...] Sem falar nas deficiências que os alunos chegam ao Ensino Médio". $\left(\mathrm{P}_{1}\right)$

Percebemos no discurso acima evidências de que a FMC somente deverá ser abordada após toda a programação da Física Clássica. Assim, a FMC não e percebida pelo professor $\mathrm{P}_{1}$ como tendo pressuposições distintas da Física Clássica.

Solicitado a idealizar um contexto em que o tempo para as aulas de Física não fosse uma problemática, a FMC também não seria contemplada na programação de ensino do professor $\mathrm{P}_{1}$ : "Olha. Não tenho como dizer agora. Preciso de um tempo pra pensar. Simples. Não dá pra você trazer aquele formalismo matemático da Física Moderna para o Ensino Médio. Veja Quântica, por exemplo. Como trabalhar uma função de onda com os alunos do Ensino Médio? Ele não sabe nem o que é uma grandeza complexa. [...] É isso. É muito abstrato pra eles" $\left(\mathrm{P}_{1}\right)$.

Evidencia-se no discurso do professor $\mathrm{P}_{1}$ uma compreensão da FMC restrita ao seu formalismo matemático. Teria sido a formação desse professor restrita a ênfases nesse formalismo, sem uma discussão dos aspectos epistemológicos e ontológicos subjacentes? Buscaremos aclarar este questionamento na próxima seção.

A perspectiva de a FMC ser trabalhada pelo professor em uma perspectiva restrita ao seu formalismo matemático inviabiliza a possibilidade de construção de um ensino em sintonia com questões sociais mais amplas (Zanetic, 2005), como também ser abordada em articulação com a cultura, conforme sugerem Carvalho e Zanetic (2002).

$O$ fator tempo também foi alegado pelo professor $\mathrm{P}_{5}$ como principal impedimento para a introdução da FMC em suas aulas de Física: "O tempo não é suficiente nem pra trabalhar a Física Clássica [...] e com as dificuldades dos alunos, a gente não consegue avançar muito, aí não da pra terminar a Física Clássica" $\left(\mathrm{P}_{5}\right)$.

Solicitado a discorrer sobre uma possível estratégia para introduzir a FMC nas aulas de Física, o professor $\mathrm{P}_{5}$ se diz sem sugestão: "Como ainda não trabalhei a Física Moderna e Contemporânea no Ensino Médio, prefiro não opinar no momento" $\left(\mathrm{P}_{5}\right)$. 
Mencionando a ausência de experiência em relação ao ensino da FMC na educação básica, o professor $\mathrm{P}_{5}$ despreza a necessidade de uma formação adequada e não da experiência em si. Isso evidencia que os processos formativos não foram necessários para uma reflexão em torno das necessidades em sala de aula, postura essa tão característica da racionalidade técnica.

$\mathrm{O}$ professor $\mathrm{P}_{3}$ mostra-se reticente em relação à introdução da FMC nas aulas de Física. Alega não ter tido formação necessária, haja vista ser uma Física que requer um pouco mais de abstração. Ao contrário, na Física Clássica, quando o professor não possui um conhecimento satisfatório, poderá fazer um resumo dos livros didáticos utilizados. Com a FMC, acredita ele que essa estratégia seja inválida: "Com as aulas que tive, fica difícil até me situar. Pelo menos agora [...] Sem condições. Simplesmente isso. [...] não sei como seria. Por onde começar? Quais os conteúdos? Não faço a mínima ideia" $\left(\mathrm{P}_{3}\right)$.

Reportando-se a uma abordagem específica em uma componente curricular, comenta: "Por exemplo, naquele capítulo que fala da equação de Schrödinger... você usa EDP, EDO, encontra aquelas constantes. Se tirar os cálculos, o que fica? Nada" $\left(\mathrm{P}_{3}\right)$.

Percebe-se nos discursos dos professores que durante as respectivas formações foram contemplados, direta ou indiretamente ${ }^{4}$, com abordagens da teoria quântica que trazem as marcas do programa pedagógico de Feynman et al. (1965). A adoção desse formalismo parece não ter contribuído para que os professores entrevistados tenham construído uma visão conceitual, epistemológica e ontológica satisfatória da mencionada física. Isso resulta na impossibilidade de procederem com adequações pertinentes para contemplarem a FMC no nível médio da educação básica.

Freire (2006) discute as dificuldades de um professor que teve sua formação pautada na memorização mecânica e repetição de ideias em tornar-se um professor crítico, tendo em vista que não percebe nenhuma relação desse conhecimento memorizado com as estruturas que necessitam ser questionadas. Esse conhecimento não ressoa com os conhecimentos necessários à emancipação.

$4 \mathrm{Na}$ verdade, a abordagem de Feynman et al. (1965) foi pouco utilizada nos cursos de MQ. Uma das razões precípuas é que ela não atendia às necessidades de um curso instrumental. Dizia-se, muito frequentemente, que ela era boa para quem já soubesse $\mathrm{MQ}$, mas não para introduzir esta disciplina a principiantes. 
O professor $\mathrm{P}_{5}$ também atribui às deficiências da sua formação a impossibilidade de introduzir a FMC nas aulas de Física.

O descompasso entre as sugestões dos pesquisadores acerca da urgente necessidade de introduzir-se o ensino da FMC na educação básica e as impossibilidades dos professores de Física aqui entrevistados em fazê-lo assemelha-se às constatações de Almeida (2003) acerca da leitura das recomendações da academia, endereçada ao professor de Física da educação básica brasileira. Ou seja, dizem aos professores o que deverá ser feito, porém, não se considera as reais condições a que estes encontram-se submetidos para fazê-lo, tampouco o significado de tais proposições.

Diante do contexto acima, analisaremos nos discursos dos professores entrevistados as marcas das diretrizes que permearam a formação deles, especificamente no tocante ao ensino da FMC.

\section{As marcas da racionalidade técnica na formação dos professores}

Devido às evidências nos discursos dos professores que os impedimentos em introduzir a FMC em suas programações curriculares estariam associadas a restrições das respectivas formações profissionais, passemos a interpretar os discursos relacionados.

Sobre o ensino da FMC na educação básica, o professor $\mathrm{P}_{2}$ menciona que não ocorreu nenhuma abordagem sobre essa possibilidade. Menciona: "Como falei, não sei se existem técnicas mais atuais, dentro da área de educação, dentro dessa área pedagógica, mostrando como ela pode ser trabalhada essa parte de Física Moderna, como ela pode ser exposta, como ela pode ser contextualizada, como pode ser abordada em sala de aula. Realmente eu desconheço. Talvez até exista" $\left(\mathrm{P}_{2}\right)$.

No discurso do professor $\mathrm{P}_{2}$, perpassa a concepção de estratégias de ensino como uma técnica. Esta deveria ter sido abordada pelos professores da área pedagógica. Neste discurso, ecoa uma concepção de que caberia à área pedagógica a técnica do como ensinar?

Em oposição à perspectiva de que os professores sejam formados como sendo técnicos, Silva (2004) assinala: 
[...] os professores e as professoras não podem ser vistos como técnicos e burocratas, mas como pessoas envolvidas nas atividades da crítica e do questionamento, a serviço do processo de emancipação e libertação (p.54-55).

Atribuir à área pedagógica e à educação o papel de apresentar técnicas de exposição da FMC para estudantes da educação básica perpassa uma voz sem nome, conforme pontuado por Orlandi (2002), a qual traz as marcas de uma matriz curricular estruturada em disciplinas de conteúdos específicos e disciplinas pedagógicas, sendo estes desenvolvidos com abordagens e propósitos distintos. Assim, incorpora uma visão de currículo ainda permeada pelo modelo " 3 + 1", que, conforme Pereira (2000), foi legalizado no Brasil no final da década de 1930 para os cursos de pedagogia.

Rosa e Schnetzler (2003) mencionam essa separação entre disciplinas chamadas de conteúdos específicos e disciplinas pedagógicas, trabalhadas sem relação entre si, como uma influência da racionalidade técnica na formação de professores.

Visando a superação do predomínio da racionalidade técnica do ensino, uma alternativa que se mostra entre teóricos críticos é a adoção de uma racionalidade que favoreça o diálogo entre os participantes e a problematização do conhecimento por estes (Hermann, 1999; Muhl, 2003a; 2003b). Esses autores fundamentam-se em conceitos da racionalidade comunicativa habermasiana, na qual a comunicação livre de imposições entre os membros de uma organização é condição sine qua non para a emancipação (Habermas, 1973; 1990).

No discurso dos professores, emergem aspectos relacionados com as posturas adotadas pelos professores formadores. Reportando-se às aulas de Mecânica Quântica, por exemplo, o professor $\mathrm{P}_{2}$ menciona:

As aulas eram expositivas. É... sempre expositivas. O quadro era usado em excesso. Assim, muitas equações, muitas definições. É, a gente sente também a questão da explicação. Por mais que o professor saiba, mas, há a dificuldade em transmitir aquele conhecimento. [...] São conceitos totalmente abstratos. Não é uma coisa que você visualiza. Faz parte do micro.... E uma coisa totalmente abstrata, certo? [...] Como que ele poderia demonstrar o comportamento da partícula através do spin? [...] A disciplina se resumia nisso $\left(\mathrm{P}_{2}\right)$.

Percebe-se no discurso do professor $\mathrm{P}_{2}$ que nas aulas de Mecânica Quântica ele priorizava a apresentação do formalismo matemático, em detrimen- 
to das considerações epistemológicas e ontológicas subjacentes ao objeto do conhecimento. Esse formalismo, conforme mencionado anteriormente, parece-nos ter se tornado a percepção predominante dos professores $\mathrm{P}_{1} \mathrm{e}$ $\mathrm{P}_{2}$ em relação ao ensino de conceitos da teoria quântica na educação básica. Ou seja, o ensino da teoria quântica, em particular, restingir-se-ia ao formalismo matemático ao qual os professores foram submetidos nas respectivas formações. Com a impossibilidade de reproduzir esse formalismo no nível médio, também a impossibilidade contempla os conceitos da teoria quântica.

Em relação ao contexto das aulas de Mecânica Quântica, percebe-se que o sujeito do conhecimento não é o foco dos professores formadores. Tal postura contrapõe a concepção freireana para a qual ensinar não é transferir conhecimento, mas criar possibilidades à construção deste pelos envolvidos nas interações de ensino e aprendizagem. Assim, trabalhar-se na perspectiva da construção do conhecimento faz-se necessário à interação dialógica entre os participantes do contexto educacional, respeitando-se nessa interação a condição de cada participante (Freire, 2006).

Ampliando as evidências de que a componente curricular Mecânica Quântica foi conduzida em uma perspectiva pautada na racionalidade técnica, faremos recortes na fala do professor $\mathrm{P}_{2}^{5}$ acerca das respectivas avaliações de aprendizagem ocorridas ao longo do curso.

Basicamente, as listas de exercícios e as provas ao final de cada unidade. [...] Se não fossem as listas, não dava pra fazer as provas. [...]. É que as questões da prova eram semelhantes às das listas; às vezes, até bem mais fáceis. Só que a gente tinha uma semana pra fazer as listas, e as provas, não $\left(\mathrm{P}_{2}\right)$.

Percebemos no discurso do professo $\mathrm{P}_{2}$ que o professor formador que conduziu a mencionada componente curricular desenvolveu procedimentos que se assemelham ao que Freire (2001) denomina de educação bancária. Ou seja, a exposição dos conteúdos pelo professor, a memorização e a posterior devolução pelo aluno ao professor por meio das avaliações de aprendizagem.

5 Os professores $\mathrm{P}_{1}$ e $\mathrm{P}_{2}$ foram contemporâneos em relação às componentes curriculares cursadas. 
Também se percebe no discurso dos professores $\mathrm{P}_{3,} \mathrm{P}_{4}$ e $\mathrm{P}_{5}$ que as avaliações de aprendizagem requeriam apenas a reprodução dos conteúdos transmitidos pelo professor, mesmo sem o entendimento pelo estudante.

Acerca do contexto da sua formação, o professor $\mathrm{P}_{3}$ reporta-se às aulas da componente curricular Estrutura da Matéria. Destaca que ocorreu excessivamente pautada em um formalismo matemático, sem que este tivesse um entendimento conceitual. Menciona:

[...] usamos um livro de Mecânica Quântica. Lá naquele capítulo que fala da equação de Schroedinger. É, você usa a EDP, a EDO, encontra aquelas constantes. São os números quânticos. Se retirar os cálculos, o que fica? Nada! Acho que precisa entender como aquilo surgiu, a sua história. Eu nunca entendi aquele resultado como um número quântico. O que não consigo é associar esse número com a estrutura do átomo, assim como associo um elétron, uma órbita... $\left(\mathrm{P}_{3}\right)$

Evidencia-se assim no discurso do professor $\mathrm{P}_{3}$ que as aulas da componente curricular Estrutura da Matéria, à qual ele se refere não o possibilitou construir um entendimento minimamente satisfatório acerca de aspectos epistemológicos e até mesmo ontológicos de conceitos fundamentais da teoria quântica.

Questionado sobe a falta de entendimento acerca dos conceitos da teoria quântica, o professor $\mathrm{P}_{3}$ assinala:

Não dava pra entender porque era tudo muito corrido, muito resumido. Um programa extenso, livros resumidos e provas pra fazer. Então ficavam muitas dúvidas no meio em relação aos conteúdos $\left(\mathrm{P}_{3}\right)$.

Interpretamos no discurso do professor $\mathrm{P}_{2}$ e $\mathrm{P}_{3}$ que a prioridade dos professores formadores não focava a aprendizagem dos estudantes, mas o cumprimento de uma programação de conteúdos. Ou seja, atitudes que são fundamentadas na racionalidade com relação aos fins.

No tocante às abordagens feitas pelos professores formadores para introduzirem a FMC nas futuras aulas de Física do nível médio, também identificamos no discurso do professor $\mathrm{P}_{3}$ que essa possibilidade não foi trabalhada durante a formação básica.

Diante do perfil predominante da formação dos professores entrevistados, esboçamos os seguintes questionamentos: de que lugares falavam e 
para quem falavam os docentes das componentes curriculares que contemplavam a FMC, haja vista que não demonstravam o entendimento que estavam construindo a formação de professores de Física, mas de memorizadores e reprodutores de um formalismo matemático? Onde estava o aspecto político do ensinar e do aprender tal qual tem ressaltado Freire ao longo da sua obra?

Como poderia ter sido delineada a autonomia do professor de Física, a partir das abordagens mencionadas, para transformar e recriar o conhecimento? Percebemos no contexto das aulas e das avaliações de aprendizagem daqueles estudantes, atuais professores de Física, as marcas de uma educação que Freire denomina ao longo da sua obra de educação bancária. Isso porque a ação permitida aos estudantes no contexto das interações em sala de aula foi a de guardar conhecimento e, posteriormente, devolvê-lo. Segundo Freire (2001), essa concepção de educação perpassa por uma dicotomia homens-mundo, e não uma relação do homem com o mundo.

Pela perspectiva das abordagens nas aulas que contemplam a FMC repetição dos conteúdos pelo docente, seguindo a mesma sequência dos livros didáticos, exercícios de fixação e repetição destes pelos licenciandos nas avaliações -, questionamos de onde vem essa voz sem nome que determina que a estrutura das aulas de Física mantenha-se guiando a prática de gerações em todos os níveis de ensino. Apesar do aparente anonimato, essas determinações têm origem, conforme menciona Orlandi (2002).

Como um professor de Física que foi submetido ao padrão de formação acima poderá desenvolver estratégias no intuito de que, por meio da introdução da FMC no Ensino Médio, possa desencadear situações que visam contribuir para uma educação científica crítica e emancipatória, tendo em vista que tal perspectiva foi suplantada da formação desse professor?

\section{Algumas considerações}

Nas interpretações dos discursos dos futuros professores de Física, percebemos que as vozes que defendem a introdução da FMC na educação básica não tem sido ouvidas pelo professores formadores, haja vista esta não ser uma questão tratada nas aulas para futuros professores de Física. Isso contraria a tendência mundial de que a FMC faça parte dos currículos 
da educação básica, conforme demonstram Ostermann e Moreira (2000) e Greca e Moreira (2001).

Além disso, a estrutura curricular do curso frequentado pelos professores entrevistados e as próprias aulas contemplando a FMC para os futuros professores foram pautadas em preceitos da racionalidade técnica, conforme especificações de Rosa Schnetzler (2003), como também as próprias aulas e avaliações elaboradas pelos professores formadores.

Sem pretender generalizar as considerações acima, questionamos até que ponto os demais cursos de formação de professores de Física estão trabalhando a FMC em uma perspectiva que possibilite ao futuro professor introduzir aquela na educação básica, em uma perspectiva crítica em relação à ciência, à tecnologia, bem como quais as consequências sociais delas. Até que ponto as universidades, enquanto espaços de formação e difusão do saber, estão possibilitando que os professores de Física em exercício reelaborem seus saberes acerca do ensino da FMC e conduzam suas práticas em uma perspectiva dialógica? Para a FMC adentrar as salas de aula da educação básica, certamente faz-se necessário que os pesquisadores considerem as reais condições dos professores da educação básica, como destacado por Almeida (2003), como também a própria estrutura curricular dos cursos de formação distanciem-se da racionalidade técnica. Conceitos da racionalidade comunicativa habermasiana e da ação comunicativa freireana mostramse como uma alternativa viável para iniciar-se esse debate.

\section{Referências bibliográficas}

ALMEIDA, M. J. P. M. Meio século de educação em ciências: uma leitura de recomendações ao professor de física. 2003. 111p. Tese (Livre Docência em Metodologia de Ensino: Física) - Faculdade de Educação, Universidade de Campinas, Campinas, 2003.

BOGDAN, R.; BIKLEN, S. Investigação qualitativa em educação. Uma introdução à teoria e aos métodos. Porto: Porto Editora, Coleção Ciências da Educação, 1994.

CARVALHO, S.; ZANETIC, J. Ciência e arte, razão e imaginação: complementos necessários à compreensão da física moderna. 2004. In: ENCONTRO DE PESQUISADORES EM ENSINO DE FÍSICA, 9., 2004, Jaboticatubas. Anais... São Paulo: SBF, 2004. 
FEYNMAN, R. P.; LEIGHTON, R.; SANDS, M. Lectures on physics. vol. 3, Reading, Massachusetts: Addison-Wesley, 1965.

FLICK, U. Introducción a la investigación cualitativa. Madrid: Ediciones Morato, 2004.

FREIRE, P. Pedagogia do oprimido. Rio de Janeiro: Paz e Terra, 2001.

Pedagogia da autonomia. saberes necessários à prática docente. São Paulo: Paz e Terra, 33. ed., 2006.

GASKELL, G. Entrevistas individuais e grupais. In: BAUER, M. W.; GASKELL, G. (Orgs.). Pesquisa qualitativa com texto, imagem e som. Um manual prático. 2. ed. Petrópolis, RJ: Vozes Editora, 2003, p.244-270.

GIL, R. Análise de Discurso. In: BAUER, M. W.; GASKELL, G. (Orgs.). Pesquisa qualitativa com texto, imagem e som. Um manual prático. 2 ed. Petrópolis, RJ: Vozes Editora, 2003, p (244-270).

GIL PÉREZ, D.; SENET, F.; SOLBES, J. La introduccion a la física moderna: un ejemplo paradigmatico de cambio conceptual. Enseñanza de las Ciencias, Barcelola, n. extra, p.189-195, 1987.

GOLDEMBERG, M. A arte da pesquisa. Rio de Janeiro: Editora Record, 1997.

GRECA, I. M.; MOREIRA, M. A. Uma revisão da literatura sobre estudos relativos ao ensino da mecânica introdutória. Investigações em Ensino de Ciências, Porto Alegre, vol. 6, n.1, pp.29-56, 2001.

HABERMAS, J. Conhecimento e interesse. Rio de Janeiro; Editora Guanabara, 1973.

Pensamento pós-metafísico. Rio de Janeiro: Tempo Brasileiro, 1990.

HERMANN, N. Validade em educação. Intuições e problemas na recepção de Habermas. Porto Alegre: EDIPUCRS, 1999.

LÜDKE, M.; ANDRÉ, M. Pesquisa em educação: abordagens qualitativas. São Paulo: Editora Pedagógica e Universitária, 1988.

MACHADO, D. I.; NARDI, R. Avaliação do Ensino da Física Moderna e Contemporânea no Ensino Médio. In: Encontro Nacional de Pesquisa em Educação em Ciências, IV. Atas... Bauru, 25 a 29 de nov. de 2003.

MONTEIRO, M. A.; NARDI, R. Tendências das pesquisas sobre o ensino da Física Moderna e Contemporânea In: Encontro Nacional de Pesquisa em Educação em Ciências, VI. Atas... Florianópolis, 2007.

MÜHL, E. H. Habermas. Ação pedagógica como agir comunicativo. Passo Fundo: UPF, 2003a.

Educação e emancipação: construção e validação consensual do conhecimento pedagógico. In: FAVERO, A. A.; MÜHL, E. H. (Orgs.). Filosofia, educação e sociedade. Passo Fundo: Editora UPF, 2003b.

OLIVEIRA, F. F.; VIANNA D. M.; GERBASSI. R. S. Física Moderna no ensino médio: o que dizem os professores. Revista Brasileira de Ensino de Física. v.29, n.3, p.447-454, 2007. 
OSTERMANN, F.; MOREIRA, M. A. Uma revisão bibliográfica sobre a área de pesquisa "física moderna e contemporânea" no ensino médio. Investigações em Ensino de Ciências, Porto Alegre, v.5, n.2, paginação eletrônica, 2000.

ORLANDI, E. Análise de discurso. 4. ed. Campinas, SP: Pontes, 2002.

PEREIRA, J. D. Formação de professores: pesquisas, representações e poder. B. Horizonte: Autêntica, 2000.

ROSA, M. I. F. P. S.; SCHNETZLER, R. A Investigação-Ação na Formação Continuada de Professores de Ciências. Ciência \& Educação. v.9, n.1, p.27-39, 2003.

SHABAJEE, P.; POSTLETHWAITE, K. What happened to modern physics? School Science Review, v.81, n.297, p.51-56, 2000.

SOLBES, J.; FERNÁNDEZ, P.; GONZÁLEZ, E. Carencias en la formación docente en temas de física contemporánea en Argentina. Actas Congreso Internacional de Investigaciones en Enseñanza de las Ciencias. Barcelona, España, 2001.

SILVA, T. Documentos de identidade: uma introdução às teorias do currículo. 2. ed. Belo Horizonte: Autêntica, 2004.

VALADARES, E. C.; MOREIRA, A. M. Ensinando Física Moderna no segundo grau: efeito fotoelétrico, laser e emissão de corpo negro. Caderno Catarinense de Ensino de Física, v.15, n.2, pp.121-135, ago. 1998.

ZANETIC, J. Física e cultura. Ciência e Cultura, v.57, n.3, pp.21-24, 2005.

Física e Arte: uma ponte entre duas culturas. Pró-posições, v.17, n.1, pp.39-57, jan./abr. 2006. 



\title{
10 \\ OS PROCESSOS DE ELABORAÇÃO E OPERACIONALIZAÇÃO DE UMA ESTRUTURA CURRICULAR NA FORMAÇÃO DE PROFESSORES DE FÍSICA: AS INTENÇÕES LEGAIS, OS DISCURSOS DOS FORMADORES E SUAS PRÁTICAS DOCENTES
}

\author{
Beatriz S.C.Cortela ${ }^{1}$ \\ Roberto Nardi ${ }^{2}$
}

\section{Introdução}

A instalação do Programa de Pós-Graduação em Educação para Ciência na unidade de Bauru a partir de 2007 oportunizou que diversas pesquisas em nível de mestrado e doutorado (Nardi, 1998; Longuini, 2001; Camargo, 2003; Cortella, 2004; Bozelli, 2005; Camargo, 2006) pudessem estudar particularidades do curso de Física, de seu corpo docente e discente, subsidiando a referida reestruturação curricular.

A primeira etapa da pesquisa, aqui relatada, procurou responder à questão: como o corpo docente do departamento de Física tende a comportar-se frente às reestruturações curriculares que estão sendo propostas? Buscou-se verificar como esses docentes concebem a atual estrutura curricular do curso; as formas como eles organizam e desenvolvem suas práticas

1 Docente do Departamento de Educação, Universidade Estadual do Norte do Paraná (UENP). Doutoranda do Programa de Pós-Graduação em Educação para a Ciência. Grupo de Pesquisa em Ensino de Ciências. Faculdade de Ciências, campus de Bauru, Universidade Estadual Paulista Júlio de Mesquita Filho (Unesp).

2 Unesp - Universidade Estadual Paulista. Docente do Departamento de Educação e do Programa de Pós-Graduação em Educação para a Ciência, Faculdade de Ciências, campus de Bauru, Universidade Estadual Paulista Júlio de Mesquita Filho (Unesp).

Apoio Financeiro do Conselho Nacional de Desenvolvimento Científico e Tecnológico (CNPq). 
docentes; o quanto estão dispostos a efetuar as mudanças; quais suas principais dificuldades profissionais e suas sugestões para a melhoria do curso em questão.

Para tanto, partiu-se de uma retrospectiva histórica sobre a formação de professores de Ciências no Brasil, mais especificamente no Estado de São Paulo, usando como parâmetros as Leis de Diretrizes e Bases da Educação Nacional (Lei 4024/61, Lei 5692/71 e Lei 9394/96). A ideia foi a de levantar e analisar que fatores políticos e sociais levaram à implantação dessas $\mathrm{LDB}$ e como os docentes que as vivenciaram reagiram a elas. Isto possibilitou estabelecer relações entre os diversos fatores que, juntos, deflagraram o processo de mudança proposto pelo Estado por meio de um novo modelo educacional.

Como afirma Severino,

[...] é possível apreender, através da política educacional em geral e da legislação educacional em particular, quais os elementos ideológicos preponderantes que o Estado, e através dele as classes dominantes de uma dada sociedade, quer vincular e inculcar ao todo da população (Severino,1986, p.56).

O Estado, em sua forma política, representa uma determinada classe social, que é a detentora do poder naquele momento histórico. Assim, ele defende os interesses dessa classe dominante e suas ideologias. A concepção de ideologia adotada neste trabalho é aquela apresentada por Chauí (2001, p.84): "A ideologia é o processo pelo qual as ideias da classe dominante tornam-se ideias de todas as classes sociais, tornando-se ideias dominantes".

\section{A formação de professores e as reformas educacionais}

A formação de professores tem sido alvo de muitos questionamentos, críticas e de reformas que se acentuaram na década de 1990 não só no Brasil, mas configurando um processo mundial. Segundo Maués (2003), a partir de 1970 intensificaram-se em todo o mundo muitas transformações econômicas, políticas e sociais. Entre elas, o esgotamento do modelo fordista/keynisiano que gerou (e ainda gera) mudanças no mundo do trabalho e, consequentemente, na educação oferecida à sociedade e gerenciada pelos governos de Estado por meio das políticas públicas. 
O fenômeno de mundialização/globalização, aqui tratados como termos indistintos, representa um processo econômico de internacionalização do capital e que pretende aplicar os princípios da economia liberal a todos os setores da sociedade. O neoliberalismo, construto ideológico da globalização, constitui uma forma hegemônica de saída da crise do capitalismo, e a educação passa a ser um instrumento poderoso para atingir este fim.

Carnoy (1999) indica a existência de uma relação direta entre a globalização e as reformas educacionais, quando os organismos internacionais propõem (ou impõem) às nações que cumpram diversas metas. O objetivo delas seria o de homogeneizar o nível dos países, tornando-os mais competitivos e capazes de participar do processo de globalização. Deste modo, procuram alinhar a escola à empresa, e os conteúdos nelas desenvolvidos, às exigências e necessidades do mercado.

Segundo Maués,

A utilização da pedagogia das competências na formação dos professores está ligada às exigências das indústrias e dos organismos multilaterais. [...] instituiu um programa internacional de pesquisa denominado Definição e Seleção de Competências - Deseco, cuja finalidade é a definição das competências básicas que deverão servir como indicadores para todas as pessoas (Maués, 2003, p.106).

De acordo com Carnoy (1999), a sociedade "do saber", que substitui a "industrial", tem como recursos a informação, a lógica e a comunicação, mas busca manter a rentabilidade, o lucro, a competitividade e, portanto, o capital. Gonçalves (1999) ressalta que as atribuições do Estado estão se modificando em decorrência do desenvolvimento científico e tecnológico, e as grandes empresas passaram a intervir, de forma mais direta e sistemática, em decisões que antes eram de responsabilidade dos governos. Assim, o desenvolvimento do conhecimento científico e tecnológico passa a prover o sistema capitalista de um mecanismo regular que assegura a sua manutenção.

Nessa perspectiva, as reformas educacionais representam um instrumento de regulação social que busca o equilíbrio e a homeóstase social: é o mercado que passa a determinar o que a educação deve fazer, desde a escolha dos conteúdos e metodologias, e até estabelecer quais concepções pedagógicas serão adotadas como corretas, no sentido de estarem de acordo com o modelo proposto. 
Segundo Costa (2005, p.45-47), na década de 1990, sob a influência do pensamento e de práticas neoliberais e também em concordância com as medidas sugeridas pelo Banco Interamericano de Desenvolvimento, pelo Banco Mundial e pela Organização das Nações Unidas, o governo brasileiro renova as parcerias com o governo americano visando à melhoria do ensino, nos moldes do projeto MEC-Usaid ${ }^{3}$, que "refletem uma orientação eminentemente tecnológica, privatizante, economicista, em suma, que subordinam a educação aos interesses do 'mercado"' (Costa, 2005, p.35).

A atual LDB, aprovada em 1996, determina que os currículos do Ensino Fundamental e Médio devem ter uma base nacional comum (Art. 26) e afirma que esta base traz, em si, a dimensão de preparação para o trabalho e também para o prosseguimento dos estudos. Ou seja, "as leis de mercado", que Chauí (2001) chama de ideologia invisível, já se fazem presentes nas instituições de ensino de nível fundamental e médio também no discurso de documentos oficiais.

Em 1996, foram publicados os Parâmetros Curriculares Nacionais (PCN), que, baseados em modelos usados na educação espanhola, visam apresentar, por meio de concepções interacionistas, conteúdos, metodologias e formas de avaliação para todas as disciplinas e séries da educação básica. Esses documentos salientam que se torna desnecessário memorizar conhecimentos que estão sendo superados ou cujo acesso é facilitado pela tecnologia; que o educador deve buscar priorizar o desenvolvimento de habilidades e competências básicas, e não o acúmulo de algoritmos para a resolução de problemas preestabelecidos, uma vez que os algoritmos devem fazer parte de um conhecimento maior que explicita, em uma linguagem simbólica, toda uma série de conceitos e generalizações.

Com tantas mudanças em curso, fez-se necessário também redimensionar a formação dos professores que irão atuar na Educação Básica. "Sob esta ótica, a qualidade da formação dos professores é elemento impulsionador e realizador dessas reformas [...]"'(Freitas, 2005, p.90). É evidente que

3 Projeto MEC-Usaid, resultante de acordos entre a United States Agency for International Developmente (Usaid) e o Ministério da Educação (MEC) visando à reforma do ensino nos vários níveis, desde o primário até o Ensino Superior e a formação de professores para o Ensino Médio, além de um convênio com o Sindicato Nacional dos Editores de Livros (SNEL) para a compra e distribuição gratuita de cinquenta milhões de livros didáticos e técnicos (Costa, 2005, p.36). 
as universidades e as instituições de Ensino Superior são vistas pelo Estado como importantes parceiras na responsabilidade pelo êxito na implantação do novo modelo educacional.

Deste modo, juntamente com as reformas no Ensino Básico, mudanças nas estruturas curriculares dos cursos superiores também foram regulamentadas por meio da implantação de Diretrizes Curriculares para formação de professores, em nível de graduação, licenciatura plena (CNE/CP 1/2002).

Da mesma forma que o educador deve ter uma habilitação técnica fundamentada nos conhecimentos científicos, no domínio dos conteúdos e no uso de métodos e técnicas de ensino, ele também necessita ter uma formação política e filosófica, precisa se ver como membro de uma sociedade em certo momento histórico. Como afirma Masetto,

O papel do professor universitário está em crise e deve ser totalmente repensado. O papel de transmissor de conhecimento, função desempenhada até quase os dias de hoje, está superado pela própria tecnologia existente. Qual é esse novo papel? (Masetto, 2002, p.18).

\section{A pesquisa: os sujeitos e a construção do corpus}

Ao escolher a amostra de sujeitos que fariam parte da pesquisa, buscou-se responder à seguinte questão: quais indivíduos têm maior vinculação ao problema que está sendo investigado? Segundo Minayo (1992) a amostragem será considerada boa se possibilitar abranger a totalidade do problema investigado em suas múltiplas dimensões.

Diversos autores mostram que os professores, em todos os níveis de ensino, desde o fundamental ao universitário, deixam marcas nos futuros docentes. Sobre essa questão, Camargo (2003) afirma que aquelas deixadas pelos professores das disciplinas específicas estavam mais evidentes na forma como os licenciandos da instituição pesquisada ministraram suas aulas durante o estágio supervisionado do que aquelas deixadas pelos docentes das disciplinas pedagógicas. Ou seja, suas práticas evidenciaram que eles podem ter "aprendido" a ministrar suas aulas utilizando diversas abordagens, mas, ao executá-las, utilizaram-se de metodologias de ensino tradicionais. 
Por essa razão, optou-se por ouvir os docentes universitários que trabalhavam com os alunos da licenciatura em Física que ministravam disciplinas específicas e que estavam participando, direta ou indiretamente, da reestruturação pretendida. Foram entrevistados onze (dos treze) docentes do Departamento de Física que atuavam na licenciatura em questão durante 2003/2004. Cada entrevista durou, em média, quarenta minutos, foram gravadas em áudio e, posteriormente, transcritas. Cada uma das linhas transcritas foi numerada, e as falas, recortadas e citadas durante o processo de análise dos dados.

Durante as entrevistas, buscou-se levantar dados que pudessem levar à interpretação dos discursos desses docentes a respeito de diversos temas, tais como: os procedimentos de ensino que utilizam; como compreendem que ocorre a aprendizagem de seus alunos; até que ponto percebem que suas concepções sobre ensino e aprendizagem podem influenciar na forma como a reestruturação curricular será posta em prática, entre outros.

Optou-se pelo uso das entrevistas semiestruturadas visando interpretar os discursos dos docentes universitários, uma vez que, quando o sujeito está sendo entrevistado, ele acaba se inserindo em formações discursivas típicas de uma determinada classe ao utilizar um vocabulário próprio, ideologias e outras marcas que permitem ao pesquisador perceber (em função do que está sendo proposto) o que ele sabe, analisa e critica a respeito dos assuntos estudados.

Vale lembrar que os investigadores qualitativos buscam analisar os dados em toda sua extensão e não os recolhem com o objetivo de confirmar ou não hipóteses previamente estabelecidas. As abstrações vão sendo construídas à medida que os dados vão sendo recolhidos e agrupados. Vale salientar que "[...] o pesquisador é o instrumento principal na coleta e na análise dos dados. Os dados são mediados pelo instrumento humano: o pesquisador." (André, 2001, p.28).

Em linhas gerais, o protocolo de entrevistas buscou levantar e analisar: 1) o grau de descontentamento com a estrutura curricular atual do curso (2002-2003); 2) o comprometimento desses docentes com o processo de reestruturação prestes a ser iniciado; 3) a forma como eles organizam e desenvolvem suas práticas docentes; 4) suas principais dificuldades profissionais e; 5) suas sugestões para melhoria do ensino e, consequentemente, do curso em questão. 
Como já comentado, o objetivo seria o de levantar o perfil dos docentes e analisar como eles se comportariam durante esse processo de reestruturação. Mas também, como afirmam Bogdan \& Biklen (1994, p.287), o objetivo, em ouvi-los, "[...] não é o de fazer um juízo de valores, mas o de tentar compreender o mundo dos sujeitos e determinar como e com que critério eles o julgam". Pois, ainda segundo os autores acima, um dos equívocos frequentemente cometidos na área educacional é que os indivíduos que propõem mudanças na área educacional, seja para todo o sistema educacional, seja para uma sala de aula, poucas vezes analisam o que pensam as pessoas que estão envolvidas nesse processo.

Consequentemente, são incapazes de antecipar com precisão a forma como os participantes irão reagir. Caso desejemos que a mudança seja efectiva, temos que compreender a forma como os envolvidos entendem sua situação, pois são eles que terão que viver com as mudanças (Bogdan \& Biklen, 1994, p.265).

A partir dos discursos dos entrevistados, foi possível interpretar suas posições, permitindo perceber até que ponto os docentes estão preparados - ou mesmo dispostos - a refletir sobre suas práticas docentes em função da implantação de novas propostas curriculares. Essa análise se fez necessária, pois não são simplesmente novas estruturas curriculares que devem garantir as mudanças esperadas na formação de professores. É preciso lembrar que as mudanças curriculares visam atender ao "espírito da lei" a que estão atreladas e que as reformas ocorrem, entre outros fatores, para que os objetivos que a referida lei defende sejam efetivados. Como afirma Krasilchik (2000, p.85), "nossas escolas, como sempre, refletem as maiores mudanças da sociedade [...] política, econômica social e culturalmente e a cada novo governo ocorre um surto reformista que atinge principalmente os ensinos básico e médio [...]”.

Cada entrevista foi analisada integralmente utilizando-se a perspectiva da Análise de Discurso (AD). Primeiro, foram feitas as notas de campo, chamadas de Comentários do Observador, que buscaram aproximar o leitor do campo de observação da pesquisadora e das condições de produção do discurso. Depois, as entrevistas foram transcritas para que também o leitor pudesse fazer a "sua" interpretação das falas dos sujeitos. Seguem-se as análises das falas e dos não ditos e a explicitação do discurso do professor, segundo a interpretação da pesquisadora: são as marcas do discurso, o que está implícito na fala do sujeito, a posição de onde ele fala. 
Um dos primeiros pontos a se considerar para a análise dos dados é a construção daquilo que a AD denomina corpus. Sua delimitação não segue critérios empíricos (positivistas), mas teóricos. O corpus está intimamente ligado à análise, pois quando se decide o que vai fazer parte dele, já se está decidindo acerca das suas propriedades discursivas uma vez que, quando se organiza o material, leva-se em conta a pergunta, o ponto de vista de quem o organiza. Como o objeto do discurso não é dado, o material bruto deve ser trabalhado pelo analista. Para tanto, deve-se converter o corpus bruto, o dado empírico, em um discurso concreto, em objeto linguisticamente dessuperficializado.

Orlandi (2002, p.65) chama dessuperficialização o processo em que, com o material bruto coletado, faz-se uma análise linguística: quem disse, o quê disse, como disse, buscando pistas que explicitem como o discurso está contextualizado, uma vez que seus autores deixam vestígios no fio do discurso. O objetivo é procurar construir, a partir do material bruto (a transcrição da entrevista), um objeto discursivo para, então, interpretar o que é dito nesse discurso e o que é dito em outros, em diferentes condições, afetados por diferentes memórias discursivas. Então, pode-se começar a analisar a discursividade, que se desenvolve por meio do raciocínio dedutivo.

A linguagem, enquanto discurso, não é formada apenas de signos que sevem para comunicação ou suporte para o pensamento: é uma interação e uma produção social. Desta forma, não pode ser considerada neutra e nem natural. Quando o pesquisador passa a buscar a compreensão da linguagem não mais centrada apenas na língua (considerada um sistema ideologicamente neutro), mas buscando a real significação de um texto em condições sócio-históricas, aí é que ocorre a Análise do Discurso.

\section{A análise dos dados: análise do discurso}

A análise dos dados recolhidos foi conduzida por meio de técnicas de Análise de Discurso (AD). Existem várias linhas de AD: a usada neste trabalho foi aquela desenvolvida no Brasil por Orlandi (2002) e Brandão (1997), a partir dos estudos de M. Pêcheux: a chamada linha francesa. Orlandi considera que existem diferentes maneiras de se estudar a linguagem: a Linguística, a Gramática e a Análise do Discurso. Quando se estuda a língua enquanto sis- 
tema de signos ou como sistemas formais, tem-se a Linguística; quando no foco de interesse estão as normas de bem dizer, temos a Gramática; quando se tenta compreender a língua fazendo sentido enquanto um trabalho simbólico, como parte do trabalho social, tem-se a Análise do Discurso (AD).

Assim, a $\mathrm{AD}$ não trabalha a língua enquanto sistema abstrato, mas como forma de significar o mundo; com homens falando, tanto como sujeitos quanto membros de uma sociedade, estando fato, história e sociedade em uma relação de dependência. Segundo Orlandi (2002), se a materialidade específica da ideologia é o discurso, e se a materialidade específica do discurso é a língua, então a AD trabalha a relação língua-discurso-ideologia.

Quando o analista passa do corpus bruto para o objeto discursivo e deste para o processo discursivo, ele mostra o trabalho da ideologia: os efeitos da língua na ideologia e a materialização desta na língua. Com isso, apreende-se a historicidade do texto. Apesar de a análise não ser objetiva, ela deve ser o menos subjetiva possível, explicitando o modo de produção de sentidos do objeto de observação.

Dois conceitos são nucleares para a AD: o de ideologia e o de discurso. Na linha francesa, valem os conceitos de Althusser, do lado da ideologia; e os de Foucault, para o discurso. Para Althusser, a escola é responsável pela inculcação da ideologia dominante, por meio do conhecimento e valores que transmite. É um meio de reprodução de forças vigentes na sociedade e, como afirma Severino:

[...] a educação procede ideologicamente em dois níveis: enquanto processo, pois transmite e reproduz conteúdos culturais, impondo-os às classes dominadas; enquanto ideologia pedagógica ou sistema de pensamento, que tem por objetivo camuflar, através de um discurso articulado, as reais relações de violência material e simbólica. (Severino,1986, p.48)

Para Foucault, o discurso é uma família de enunciados que pertencem a uma mesma formação discursiva. As formações discursivas são aquelas que determinam o que pode e o que deve ser dito em uma determinada situação. Como as palavras possuem posições ideológicas, as formações discursivas fazem parte das formações ideológicas. Palavras iguais podem ter significados diferentes, uma vez que se inscrevem em formações discursivas distintas. Desta forma, o que caracteriza a AD é a "posição" do locutor: a relação entre quem fala e o mundo. 
As formações ideológicas são formadas por um conjunto de atitudes e representações que não são individuais, mas que estão relacionadas com as posições de classes em conflito. Nelas, os silêncios são tão importantes quanto as falas dos sujeitos. Há um silenciamento constitutivo quando o sujeito escolhe uma determinada forma de representação de ideias, que não é neutra e nem ingênua. Outras vezes, ocorre um silenciamento local, que é quando o sujeito não diz o que quer dizer, pois há alguma forma de censura.

Assim, observou-se com cuidado o modo com que o texto foi construído pelo entrevistado, a forma como ele argumenta e estrutura sua fala, e, por meio de diferentes leituras feitas pela pesquisadora, buscou-se, nos vestígios deixados pelo autor, efetuar a análise e interpretação deste. Segundo Orlandi (2002), o analista do discurso não é um hermeneuta: ele trabalha nos limites da interpretação. Ele não se coloca fora da história, da ideologia, e sim em uma posição deslocada que lhe permite contemplar (encarar, pensar sobre) o processo de produção dos sentidos.

\section{Interpretação dos dados: algumas análises}

Buscando elucidar a questão principal da pesquisa - como o corpo docente do departamento de Física deste campus universitário analisado tende a comportar-se frente às reestruturações curriculares que estão sendo propostas para o curso de licenciatura em Física -, a pesquisadora focou sua atenção na seguinte lógica: se o primeiro passo em direção à mudança é estar descontente com o modelo atual, a fala desses professores reflete um real descontentamento quanto à formação oferecida aos seus alunos?

Caso isso seja verdade, quais as competências que eles gostariam que seus alunos, futuros professores, alcançassem? Para que essas competências que eles almejam sejam desenvolvidas, como eles estão trabalhando durante suas aulas? Quais suas dificuldades ao tentarem realizar um trabalho diferenciado? O que os docentes sabem a respeito das Diretrizes Curriculares para Formação de Professores e dos PCN que estão servindo de subsídios para a reestruturação curricular que está sendo proposta?

Como afirma Brandão (2002, p.38), os discursos dos sujeitos são governados pelas formações ideológicas, ou seja, por um conjunto de atitudes e representações que não são individuais, mas que estão relacionadas com as 
posições de classes. Sendo assim, nem sempre quando o sujeito manifesta um desejo de mudança, isso se concretiza ou é realmente verdade. Muitas vezes, as pessoas dizem aspirar por mudanças buscando concordar com um grupo ou ideias dominantes; ou então, pelo contrário, para contestar este mesmo grupo ou sistema ideológico.

Às vezes, mesmo que as mudanças sejam desejadas, o docente pode não se sentir (ou não estar) preparado psicológica, pedagógica ou filosoficamente para tais mudanças. Psicologicamente, no sentido de que algumas pessoas, mesmo estando capacitadas para a mudança, temem os fatores decorrentes desta, ou não estão dispostas a passar pelo desgaste de sair de uma posição conhecida; pedagogicamente, no sentido de os sujeitos terem (ou sentirem que têm) dificuldades nos conhecimentos da área de educação, indispensáveis para poderem ministrar suas aulas com a liberdade que advém da competência de transpor os conhecimentos específicos para um nível de ensino a ser oferecido, de utilizar as diversas estratégias para transformar o conteúdo específico em conteúdo pedagógico; filosoficamente, porque mesmo estando dispostas e sendo pedagogicamente aptas, não conseguem perceber as formas de condução ideológica que existem nos modelos pedagógicos que empregam ou não distinguem, filosoficamente, um modelo do outro. Sendo assim, não estão conscientes de que estão sendo conduzidos a fim de formarem profissionais com determinados perfis, sendo estes ditados pela "ideologia invisível", exercida pelo ideal político vigente.

Esses sentimentos podem ser percebidos, em diferentes graus, em algumas falas dos sujeitos, quando descrevem como gostariam de estruturar o curso em questão. Quando perguntados, por exemplo, sobre o que acham que deveria ser mudado na reestruturação, aparecem as seguintes colocações:

Prof. A: "Em linhas gerais, eu vou falar: TUDO. [...] eu mudaria e começaria estabelecendo eixos, né!" [lendo a entrevista toda, percebe-se a posição do sujeito: eu quero, eu sei o quê, como e por que gostaria que as mudanças ocorressem].

Prof. C: "Até, talvez, ninguém saiba o quanto que o professor de Ensino Médio tem que saber. Porque, o tempo pra dar tudo o que é dado no bacharelado não tem." [percebe-se: eu quero mudanças, mas se os conteúdos devem continuar os mesmos, não vai dar tempo de ministrar tudo desta nova forma; então, não sei o que, nem como mudar]. 
Prof. D: "Eu acho que uma coisa a gente deveria proporcionar a eles e eles não têm, com certeza, eles deveriam sair daqui seguros sobre o conteúdo que têm que ensinar, né? [...] aliado a isso, técnicas de transmissão, de ensino." [subentende-se: eu quero mudar, mas não sei como fazê-lo, pedagogicamente falando].

Para facilitar a sistematização das análises, foram montadas tabelas relacionando os sujeitos e suas ideias. Serão apresentadas, neste trabalho, apenas duas delas.

\section{A - Opiniões dos sujeitos a respeito das propostas de mudanças na estrutura curricular}

I - Quer mudanças e está preparado para elas: psicológica, filosófica e pedagogicamente.

II - Quer mudanças, mas não está preparado, em algum (ns) aspecto (s).

III - Não quer mudanças, apesar de achar que a formação oferecida não está satisfatória.

IV - Não quis opinar diretamente, mas demonstra certo descontentamento.

\begin{tabular}{|c|c|c|c|c|}
\hline Sujeito & I & II & III & IV \\
\hline A & & & & $\mathrm{x}$ \\
\hline B & & & & $\mathrm{x}$ \\
\hline C & & $\mathrm{x}$ & & \\
\hline D & & $\mathrm{x}$ & & \\
\hline E & & & $\mathrm{x}$ & \\
\hline F & & & & $\mathrm{x}$ \\
\hline G & & & $\mathrm{x}$ & \\
\hline H & & $\mathrm{x}$ & & \\
\hline I & & & & $\mathrm{x}$ \\
\hline J & & & & $\mathrm{x}$ \\
\hline
\end{tabular}

A maioria dos docentes entrevistados concorda que a licenciatura, da forma como está organizada e sendo ministrada, não está formando professores de nível médio de maneira satisfatória e, portanto, estão descontentes. Quase a metade deles está disposta a tentar fazer mudanças; outro tanto as deseja, mas não sabe como fazê-las. 
Alguns pontos críticos são citados pelos docentes no modelo de licenciatura em Física oferecido entre 2002-2003: todos os entrevistados admitem que não fazem um trabalho interdisciplinar sistemático; também dizem que estão pouco tempo em contato uns com os outros para poderem discutir sobre conteúdos e metodologias e também discordam da forma como a estrutura curricular da licenciatura é elaborada e desenvolvida, como se fosse um bacharelado.

Pôde-se perceber que, se existe um projeto pedagógico para a licenciatura, ele não é desenvolvido em conjunto pelos docentes, ou que os professores não o conhecem de modo suficiente. Também se pôde perceber que existia certa distância entre os docentes das disciplinas específicas e daquelas ligadas à Educação, talvez sendo favorecida pela forma como a universidade está estruturada, em departamentos: cada qual com seus docentes, suas disciplinas e seus projetos, favorecendo o modelo tradicional de ensino.

A maioria dos sujeitos diz que um dos problemas graves desse curso é a forma como a atual estrutura curricular da licenciatura é desenvolvida, como se fosse um bacharelado. Eles utilizam algumas construções verbais interessantes ao se referirem ao currículo de licenciatura em Física: samba do crioulo doido; curso Frankenstein; uma meleca, entre outras. Além da estrutura curricular da licenciatura ser muito parecida com a de um curso de bacharelado, a sistemática de trabalho adotada pelos docentes para os dois cursos também é muito similar, apesar de o perfil profissional do professor ser diferente do de bacharel.

Outra fala que aparece em muitos dos discursos dos docentes que demonstram estar predispostos a fazer as mudanças é que eles não creem que seus colegas irão se comprometer com esse novo modelo curricular proposto. Parece haver uma crença entre alguns professores de que mesmo que a estrutura curricular mude, os colegas continuarão a ministrar suas aulas da mesma forma que estão fazendo hoje. Fica subentendido que as coisas podem mudar no papel, mas que a prática continuará sendo a mesma.

Prof. J: "Pelo que eu conheço, não [...] Agora, tem uns que vão lá, dão aula e acham que isso não muda!"

Prof. D: "Olha, moçada: vocês vão ter que capacitar os seus docentes. [...] Vocês vão ter que reciclar seus professores, tá muito ruim [...]."

Os docentes acreditam que o currículo da licenciatura deveria ser modificado, buscando atender às expectativas de trabalhar melhor a parte 
tecnológica da Física e alguns conteúdos como Cosmologia e Astronomia, citados nos PCN e não contemplados no currículo atual. Disseram também que algumas das disciplinas da área de Educação deveriam ter suas cargas horárias aumentadas, ou, pelo menos, ser trabalhadas de forma mais distribuída durante o curso, não ficando concentradas apenas nos últimos termos do curso, como no atual modelo (2002-2003).

\section{B - Como os professores estão trabalhando, durante suas aulas, para que seus alunos possam conhecer outro modelo de ensino que não o tradicional?}

I - De forma tradicional, desde o preparo das aulas, desenvolvimento dos conteúdos e avaliação (livro-texto tradicional, resolvendo muitas listas com exercícios repetitivos, fazendo uso do ensino por transmissão, entre outros aspectos).

II - De forma ainda um pouco tradicional, mas com tendência a trabalhar com a História da Ciência, permitindo que os alunos participem mais ativamente da própria aprendizagem.

III - De forma ainda um pouco tradicional, mas tentando usar novas metodologias, novas tecnologias e/ou textos mais modernos.

\begin{tabular}{|c|c|c|c|}
\hline Sujeito/Perfil & I & II & III \\
\hline A & & $\mathrm{x}$ & \\
\hline B & & $\mathrm{x}$ & $\mathrm{x}$ \\
\hline C & $\mathrm{x}$ & & $\mathrm{x}$ \\
\hline D & $\mathrm{x}$ & & $\mathrm{x}$ \\
\hline E & $\mathrm{x}$ & & \\
\hline F & $\mathrm{x}$ & & $\mathrm{x}$ \\
\hline G & & $\mathrm{x}$ & $\mathrm{x}$ \\
\hline H & $\mathrm{x}$ & & $\mathrm{x}$ \\
\hline I & & $\mathrm{x}$ & $\mathrm{x}$ \\
\hline J & $\mathrm{x}$ & & $\mathrm{x}$ \\
\hline
\end{tabular}

Existem vários pontos favoráveis nesta análise: a maioria dos docentes está tentando efetuar mudanças: têm procurado utilizar diferentes recursos didáticos, elaborar textos mais modernos, baseados em literaturas mais re- 
centes; tentando efetuar novas formas e utilizando-se de diversos critérios de avaliação. Também, na fala de alguns sujeitos, percebe-se uma mudança de postura em relação à aprendizagem de seus alunos: apesar de ensinarem de forma "transmissionista", a maioria deles não acredita que a aprendizagem ocorra desta forma: Estão pressentindo que ela ocorra de outro modo, e mesmo que não tenham ainda chegado a fazer conclusões, estão susceptíveis a novas abordagens.

No entanto, o quadro também revela que a maioria dos docentes ainda trabalha de forma bastante tradicional, servindo-se de metodologias observadas na época em que ainda eram alunos; empregando livros que utilizaram em suas graduações; usando dos mesmos critérios e instrumentos de avaliação com que foram avaliados. É o velho modelo de ensino sendo repetido: fazem como aprenderam a fazer. Ou seja, na ausência de alternativas que estejam incorporadas ao seu saber fazer, utilizam-se de práticas observadas quando ainda eram alunos, usando, inclusive, aquelas que criticaram (Carvalho, 1992).

\section{Considerações finais}

Vale ressaltar que, como afirmam Bogdan \& Biklen (1994, p.277), “[...] o trabalho dos investigadores não é sempre o de avaliar, mas também o de descrever e comentar aquilo que se passa”. Desta forma, a pesquisa, além da interpretação dos discursos de seus sujeitos, que refletem suas posições, permitiu descrever as etapas de elaboração da proposta, acompanhando os processos de planejamento e as discussões que antecederam a implantação do projeto pedagógico do curso em questão. Sendo assim, pode também subsidiar outros processos semelhantes em outras universidades.

Mais que apresentar um diagnóstico parcial de um processo de reestruturação curricular situação, este artigo visa mostrar que a reestruturação é um processo dinâmico e que há uma continuidade em seu acompanhamento, buscando apresentar e analisar novos dados que sirvam de subsídios para a melhoria do curso em questão. As mudanças geram desequilíbrios, seguidos de adaptações; surgiram novas situações que estão sendo analisadas pelo corpo docente da universidade em questão e também por pesquisadores ligados à área de ensino de ciências desta mesma instituição. 
Entende-se, por fim, que um processo de reestruturação, como o que está sendo aqui analisado, não reflete ou materializa apenas as ideologias subjacentes às reformas determinadas pelas instâncias políticas do País, mas também oferece brechas para avanços que podem ser importantes do ponto de vista dos professores, licenciandos e sociedade como um todo.

Visando dar continuidade ao trabalho, os autores deste capítulo estão retomando os dados das entrevistas cedidas pelos docentes universitários e se propõem uma nova investigação, que visa analisar como será a operacionalização desta nova estrutura curricular; como os docentes irão trabalhar o projeto político-pedagógico do curso; de que forma esses professores (ou a universidade, por meio da formação em serviço) irão buscar suprir as lacunas que alegaram ter em relação aos conhecimentos pedagógicos; e também como as etapas de trabalho docente em que se encontram podem influenciar esse processo de reestruturação.

Como afirma Perrenoud (1999, p.82), "em qualquer hipótese, deve-se romper um círculo vicioso: se o modelo de formação dos alunos for reforçado pelo modelo de formação de professores, e vice-versa, de onde virá a mudança?"

\section{Referências bibliográficas}

ANDRE, M. E. D. A. de. Etnografia da prática social. 6. ed. Campinas, SP: Papirus, 2001.

BOGDAN \& BIKLEN. Investigação Qualitativa em Educação: uma introdução à teoria e aos métodos. Coleção Ciências da Educação. Portugal, Porto Editora, 1994.

BRANDÃO, H. H. N. Introdução à Analise de Discurso. 6. ed. Campinas: Editora da Unicamp, 1997.

BRASIL. Lei no 9.394, de 20 de dezembro de 1996. Estabelece as Diretrizes e Bases da Educação Nacional. Diário Oficial da União, de 23 de dezembro de 1996.

BRASIL. Parâmetros Curriculares Nacionais: Ensino Médio. Ministério da Educação. Secretaria da Educação Média e Tecnológica - Brasília, Ministério da Educação, 1999.

BRASIL. Resolução CNE/CP 01/2002, de 18 de fevereiro de 2002. Institui Diretrizes Curriculares Nacionais, para a formação de professores de Educação Básica, em nível superior, curso de licenciatura, de graduação plena. Diário Oficial da União, Brasília, 9 de abril de 2002. Seção 1, p.31. 
CAMARGO, S. Prática de Ensino de Física: marcas de referenciais teóricos nos discursos de licenciandos. 2003. 207f. Dissertação (Mestrado em Educação para a Ciência). Faculdade de Ciências, Unesp, Bauru, 2003.

CARNOY, M. Mondialisation et reforme de l'éducation: ce que lês planificateus doivent savoir. Paris: Unesco; Institut International de Planification de l'Education, 1999.

CARVALHO, A. M. P. Reformas nas Licenciaturas: a necessidade de uma mudança de paradigma mais do que de mudança curricular. Em Aberto, Brasília, ano 12, n. 54, p.51-63, abr./jun. 1992

CORTELA, B. S. C. Formadores de professores de física: uma análise de seus discursos e como podem influenciar na implantação novos currículos. Dissertação (Mestrado em Educação para a Ciência). Faculdade de Ciências. Universidade Estadual Paulista - Unesp, campus de Bauru, 2004, 264p.

COSTA, E. V. Globalização e reforma universitária: a sobrevivência do MECUsaid. In: Trajetórias e perspectivas da formação de educadores. São Paulo: Unesp, 2005, p.35-48.

CHAUI, M. O que é Ideologia. Coleção: Primeiros Passos. 2a ed. São Paulo: Brasiliense, 2001.

FREITAS, H. C. L. de. Novas políticas de formação: da concepção negada à concepção consentida. In: Trajetórias e perspectivas da formação de educadores. São Paulo: Unesp, 2005, p.89-115.

GONÇALVES, M. A. S. Teoria da ação comunicativa de Habermas: Possibilidades de uma ação educativa de cunho interdisciplinar na escola. Educação e Sociedade, ano XX, n.66, Abr./99, p.125-140.

KRASILCHIK, M. Reformas e Realidade: o caso do ensino das ciências. São Paulo em Perspectiva, 14(1), p.85-93, 2000.

MASETTO, C. (Org.). Docência na Universidade. Campinas, SP: Papirus, 2002.

MAUÉS, O. C. Reformas Internacionais da Educação e Formação de Professores. Cadernos de Pesquisa, n.118, p.8-117, março 2003.

MINAYO, M. C. S. et al. Pesquisa Social: Teoria, Método e Criatividade. 19. ed. Petrópolis, Ed. Vozes, 2001.

ORLANDI, E. P. Análise do Discurso: Princípios \& Procedimentos. 4. ed. Campinas, SP: Pontes, 2002.

PERRENOUD, P. Construir as Competências desde a Escola. Porto Alegre: Ed. Artes Médicas Sul, 1999.

SEVERINO, A. J. Educação, Ideologia e Contra-Ideologia. São Paulo: EPU, 1986. 



\title{
11 \\ O ensino de CIÊNCIAS NAS SÉRIES INICIAIS: DESENVOLVIMENTO DE APRENDIZAGENS \\ PROFISSIONAIS NO ÂMBITO DA FORMAÇÃO DE PROFESSORES
}

\author{
Jair Lopes Junior ${ }^{1}$ \\ Paulo Cesar Gomes ${ }^{2}$ \\ Fabiana Maris Versuti Stoque ${ }^{3}$ \\ Mariana Francisco Giuzio ${ }^{4}$
}

\section{Introdução}

Admite-se, com relativo consenso, que análises e proposições de programas de pesquisa que concentrem ênfase na formação de docentes que ministram conteúdos curriculares de Ciências Naturais para as séries iniciais do Ensino Fundamental devem, no cenário atual, como condição necessária, considerar dois amplos conjuntos de conhecimentos.

O primeiro conjunto define-se pelas diretrizes pedagógicas e pelas orientações didáticas expressas em documentos oficiais, tanto quanto derivadas de um robusto acervo de evidências fundamentado em pesquisas

1 Docente do Departamento de Psicologia e do Programa de Pós-Graduação em Ensino de Ciências, Faculdade de Ciências, campus de Bauru, Universidade Estadual Paulista Júlio de Mesquita Filho (Unesp).

2 Doutorando do Programa de Pós-Graduação em Ensino de Ciências, Faculdade de Ciências, campus de Bauru, Universidade Estadual Paulista Júlio de Mesquita Filho (Unesp).

3 Doutoranda do Programa de Pós-Graduação em Ensino de Ciências, Faculdade de Ciências, campus de Bauru, Universidade Estadual Paulista Júlio de Mesquita Filho (Unesp).

4 Bolsista IC/FAPESP, Faculdade de Ciências, campus de Bauru, Universidade Estadual Paulista Júlio de Mesquita Filho (Unesp).

Apoio Financeiro do Conselho Nacional de Desenvolvimento Científico e Tecnológico (CNPq) - (400943/2006-9) e da Fundação de Amparo à Pesquisa do Estado de São Paulo (FAPESP) - (06/54654-8). 
sobre a atuação do professor das séries iniciais em sala de aula. As diretrizes e orientações sustentam consistências com o desenvolvimento, pelos alunos, de competências e de habilidades preconizadas pelos descritores que demarcam os níveis de aprendizagens almejados ao final da $4^{\mathrm{a}}$ série do Ensino Fundamental (Brasil, 2000; Carvalho, 2004; Gil Perez e Carvalho, 2001; Longhini, 2008; Paixão e Cachapuz, 1999; Sasseron e Carvalho, 2008).

O segundo conjunto de conhecimentos é constituído pelas bases epistemológicas que orientam e demarcam as aprendizagens profissionais que definem a atuação do professor no ensino de Ciências nas séries iniciais ( $\mathrm{Pe}$ reira, 2002; Zanotto, 2000; Zeichner, 2008).

Neste capítulo, advoga-se que a ênfase recorrente em explicitar metas e objetivos de ensino sob a forma de competências e de habilidades que os alunos deverão apresentar ao final do ciclo e pela proposição de práticas educativas que seriam consistentes com tais metas e objetivos (Brasil, 2000; Governo do Estado de São Paulo, 2008) ainda prescinde de uma fundamentação cientificamente sustentável sobre os recursos necessários para que o professor possa interpretar medidas de desempenhos emitidas pelos alunos nas interações previstas em sala de aula pelas diretrizes e orientações expostas. Assim, admite-se, neste trabalho, que nas orientações oficiais para o ensino de Ciências no Ensino Fundamental, em particular nas séries iniciais, constatam-se lacunas quanto à especificação dos recursos necessários e adequados que viabilizariam interpretações das correspondências entre os objetivos ou descritores de desempenhos e as medidas comportamentais resultantes das interações dos alunos com as condições de ensino e de avaliação dispostas. Por sua vez, interpretar correspondências entre práticas dispostas pelo professor e as ações emitidas pelos alunos em interação com tais práticas constitui-se em repertório comportamental de ensino, passível de aprendizagem, que define parte substancial e relevante das ações profissionais docentes em sala de aula.

A investigação descrita a seguir objetivou investigar condições de ensino que poderiam favorecer a aprendizagem, por professores que ministram conteúdos curriculares de Ciências nas séries iniciais, de repertórios comportamentais que definem a execução de avaliações funcionais descritivas e de possíveis efeitos de tais aprendizagens na atuação profissional do docente. 
Enquanto recurso metodológico de estudos fundamentados teoricamente na Análise do Comportamento (Baum, 1999; Fox e Davis, 2005; Pereira, Marionotti e Luna, 2004), a avaliação funcional descritiva cumpriria a função de viabilizar interpretações de medidas comportamentais emitidas pelos alunos em interação com as condições de ensino e de avaliação dispostas pelos professores.

De modo mais específico, o objetivo deste capítulo consistiu expor e discutir um modelo de investigação que objetivou verificar se um conjunto planejado de interações entre os pesquisadores e uma professora das séries iniciais, fundamentado no contato da professora com episódios de vídeo de aulas por ela ministrada, bem como com modelos de avaliação funcional descritiva, elaborados pelos pesquisadores, favoreceriam a aprendizagem, pelos professores, dos repertórios que definem a execução deste recurso metodológico, bem como caracterizar possíveis extensões da aquisição de tais repertórios nas atividades de ensino da professora na sala de aula.

\section{Formação de professores e aprendizagem profissional: um modelo de investigação}

Participou do estudo ora relatado uma professora, denominada P3, com 12 anos de experiência docente. Ela é efetiva no cargo de professor de Educação Básica I há um ano e meio, fez Magistério e é licenciada em Pedagogia. A docente P3 atuava na escola na qual foi realizada a pesquisa há seis meses e ministrava aulas em uma $4^{\mathrm{a}}$ série do Ensino Fundamental.

O Quadro 1 apresenta o procedimento de coleta de dados adotado.

Após a finalização do registro consecutivo das aulas das duas unidades didáticas, foi realizada a Entrevista II com P3, com a aplicação do Roteiro 2, que referiu-se exclusivamente às aulas da UD1. A primeira aplicação do Roteiro 2 (Entrevista II) ocorreu sem que a docente tivesse contato com as aulas em vídeo. Uma síntese das respostas de P3 foi descrita no Quadro 2.

A seguir, foi efetuada a seleção e a edição de episódios passíveis de interpretação com base no modelo de avaliação funcional descritiva a partir das aulas da UD1 ministradas pela professora P3. O Quadro 3 apresenta uma descrição sintética dos episódios selecionados e exibidos. 
Quadro 1 - Síntese do procedimento de coleta de dados

\begin{tabular}{|c|c|c|c|}
\hline \multicolumn{2}{|c|}{$\begin{array}{l}\text { ETAPAS } \\
\text { E FASES }\end{array}$} & EVENTOS & SÍNTESE DESCRITIVA \\
\hline \multirow{7}{*}{ 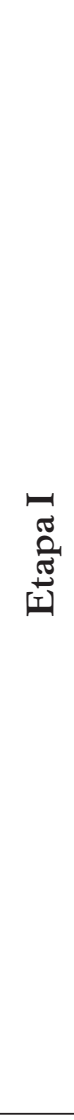 } & \multirow{3}{*}{ 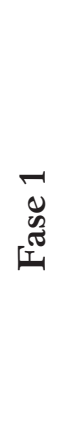 } & $\begin{array}{l}\text { Entrevista I } \\
\text { Roteiro } 1\end{array}$ & $\begin{array}{l}\text { Ocorreu a apresentação inicial e indicação do início das } \\
\text { aulas de ambientação. }\end{array}$ \\
\hline & & Ambientação & $\begin{array}{l}\text { Acompanhamento pelo pesquisador de duas aulas } \\
\text { sem auxílio de filmadora e duas com manuseio de uma } \\
\text { filmadora. }\end{array}$ \\
\hline & & UD1 e UD2 & $\begin{array}{l}\text { Filmagens das aulas de duas unidades didáticas } \\
\text { completas e contíguas (UD1 e UD2) sobre temas } \\
\text { selecionados por P3. }\end{array}$ \\
\hline & 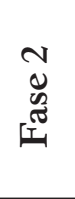 & $\begin{array}{l}\text { Entrevista II, Roteiro } 2 \\
\text { (1ª aplicação) }\end{array}$ & $\begin{array}{l}\text { A docente relatou aspectos das aulas da UD1 referentes } \\
\text { aos objetivos e estratégias de ensino e principais efeitos } \\
\text { alcançados com os alunos, sem contato com o vídeo das } \\
\text { respectivas aulas. }\end{array}$ \\
\hline & \multirow{3}{*}{ 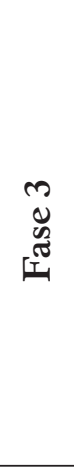 } & Análise UD1 e UD2 & $\begin{array}{l}\text { Após assistir a todas as aulas, os pesquisadores } \\
\text { efetuaram a seleção, edição e descrição de episódios } \\
\text { das aulas da UD1. }\end{array}$ \\
\hline & & Exibição da UD1 & $\begin{array}{l}\text { Apresentação à professora participante dos episódios } \\
\text { selecionados das aulas da UD1. }\end{array}$ \\
\hline & & $\begin{array}{l}\text { Entrevista III, Roteiro } 2 \\
\text { (2ª aplicação) }\end{array}$ & $\begin{array}{l}\text { Novamente, a docente relatou aspectos das aulas da } \\
\text { UD1 referentes aos objetivos e estratégias de ensino e } \\
\text { principais efeitos alcançados com os alunos, desta feita, } \\
\text { após o contato com os episódios das respectivas aulas. }\end{array}$ \\
\hline \multirow[t]{2}{*}{ 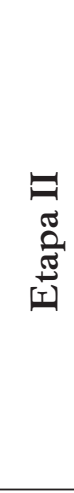 } & 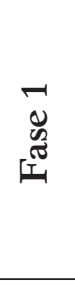 & Entrevista IV & $\begin{array}{l}\text { Reapresentação dos episódios em vídeo das aulas } \\
\text { da UD1. Apresentação do modelo de avaliação } \\
\text { funcional descritiva elaborado pelos pesquisadores } \\
\text { sobre os episódios da UD1 com o auxílio de um roteiro } \\
\text { escrito exposto em termos de eventos antecedentes e } \\
\text { subsequentes às ações da professora e/ou alunos. }\end{array}$ \\
\hline & 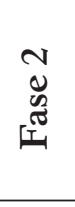 & Entrevista V & $\begin{array}{l}\text { Apresentação dos episódios em vídeo das aulas da } \\
\text { UD2. Solicitação de elaboração de uma avaliação } \\
\text { funcional descritiva sobre episódios das aulas da UD2 } \\
\text { pela professora. }\end{array}$ \\
\hline \multirow{5}{*}{ 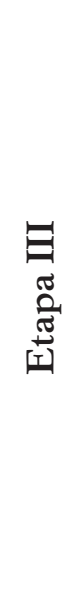 } & \multirow[b]{2}{*}{$\begin{array}{c}\overline{0} \\
\mathscr{y} \\
\text { İ }\end{array}$} & UD3 & Filmagens de uma unidade didática completa (UD3). \\
\hline & & Edição UD3 & $\begin{array}{l}\text { Após gravar e assistir todas as aulas, o pesquisador } \\
\text { procedeu ao trabalho de seleção, edição e descrição dos } \\
\text { episódios das aulas referentes à UD3. }\end{array}$ \\
\hline & \multirow{3}{*}{ 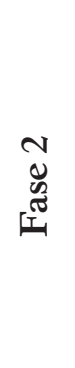 } & \multirow[b]{2}{*}{$\begin{array}{l}\text { Entrevista VI } \\
\text { Roteiro } 3\end{array}$} & Apresentação dos episódios da UD3 à docente. \\
\hline & & & $\begin{array}{l}\text { Ocorreu após a professora assistir aos episódios da } \\
\text { UD3 e foi sobre a avaliação de estratégias e objetivos } \\
\text { alcançados nesta UD. }\end{array}$ \\
\hline & & Entrevista VII & $\begin{array}{l}\text { Elaboração pela docente, sem auxílio de roteiro, de uma } \\
\text { análise comparativa final entre as unidades didáticas } \\
\text { anteriores e a UD3. }\end{array}$ \\
\hline
\end{tabular}


Quadro 2 - Síntese das respostas da entrevista II com P3.

\begin{tabular}{|c|c|c|}
\hline \multicolumn{3}{|c|}{ UD1 - Tema: Higiene e Saúde } \\
\hline $\begin{array}{c}\text { Estratégias de ensino } \\
\text { disponibilizadas na UD }\end{array}$ & $\begin{array}{l}\text { Objetivo das } \\
\text { estratégias de ensino }\end{array}$ & $\begin{array}{c}\text { Principais efeitos } \\
\text { conseguidos com os alunos }\end{array}$ \\
\hline 1. A oralidade. & 1. Fazer os alunos falarem. & \multirow[b]{2}{*}{$\begin{array}{l}\text { 1. Eles entenderam a mensagem e } \\
\text { mostraram que tinham apren- } \\
\text { dido. } \\
\text { 2. Construíram conceitos com } \\
\text { auxílio da professora. } \\
\text { 3. Troca de ideias, pois eles tinham } \\
\text { mais dificuldades em ler e es- } \\
\text { crever. } \\
\text { 4. Eles souberam manifestar oral- } \\
\text { mente suas ideias. }\end{array}$} \\
\hline $\begin{array}{l}\text { 2. Contextualização do que } \\
\text { os alunos sabiam sobre o } \\
\text { assunto, isto é, não fornecer } \\
\text { o conceito pronto, pois não } \\
\text { adiantaria ao aluno apenas } \\
\text { copiar. } \\
\text { 3. Construção de conceitos } \\
\text { com os alunos. }\end{array}$ & $\begin{array}{l}\text { 2. Não fornecer os con- } \\
\text { ceitos prontos. }\end{array}$ & \\
\hline $\begin{array}{l}\text { 4. Construção do texto cole- } \\
\text { tivo, quando os alunos en- } \\
\text { trariam em um acordo sobre } \\
\text { suas ideias. } \\
\text { 5. Promover discussão sobre } \\
\text { o assunto e troca ideias na } \\
\text { produção do texto coletivo. }\end{array}$ & $\begin{array}{l}\text { 3. Que os alunos entras- } \\
\text { sem em um acordo nas } \\
\text { discussões. } \\
\text { 4. Que os alunos falassem } \\
\text { sobre o assunto e que } \\
\text { tivessem clareza de suas } \\
\text { ideias. }\end{array}$ & $\begin{array}{l}\text { 5. Ocorreu bagunça. } \\
\text { 6. Eles falaram sobre o assunto, se } \\
\text { manifestaram, demonstraram } \\
\text { diferenças entre a higiene física, } \\
\text { mental e social. } \\
\text { 7. Participaram da atividade de } \\
\text { recortar. } \\
\text { 8. Participaram das atividades } \\
\text { escritas. }\end{array}$ \\
\hline 6. Cruzadinha & 5. Foi para eles escreverem. & 9. Eles escreveram. \\
\hline
\end{tabular}

Quadro 3 - Descrição dos episódios selecionados das aulas da UD1 e exibidos à P3.

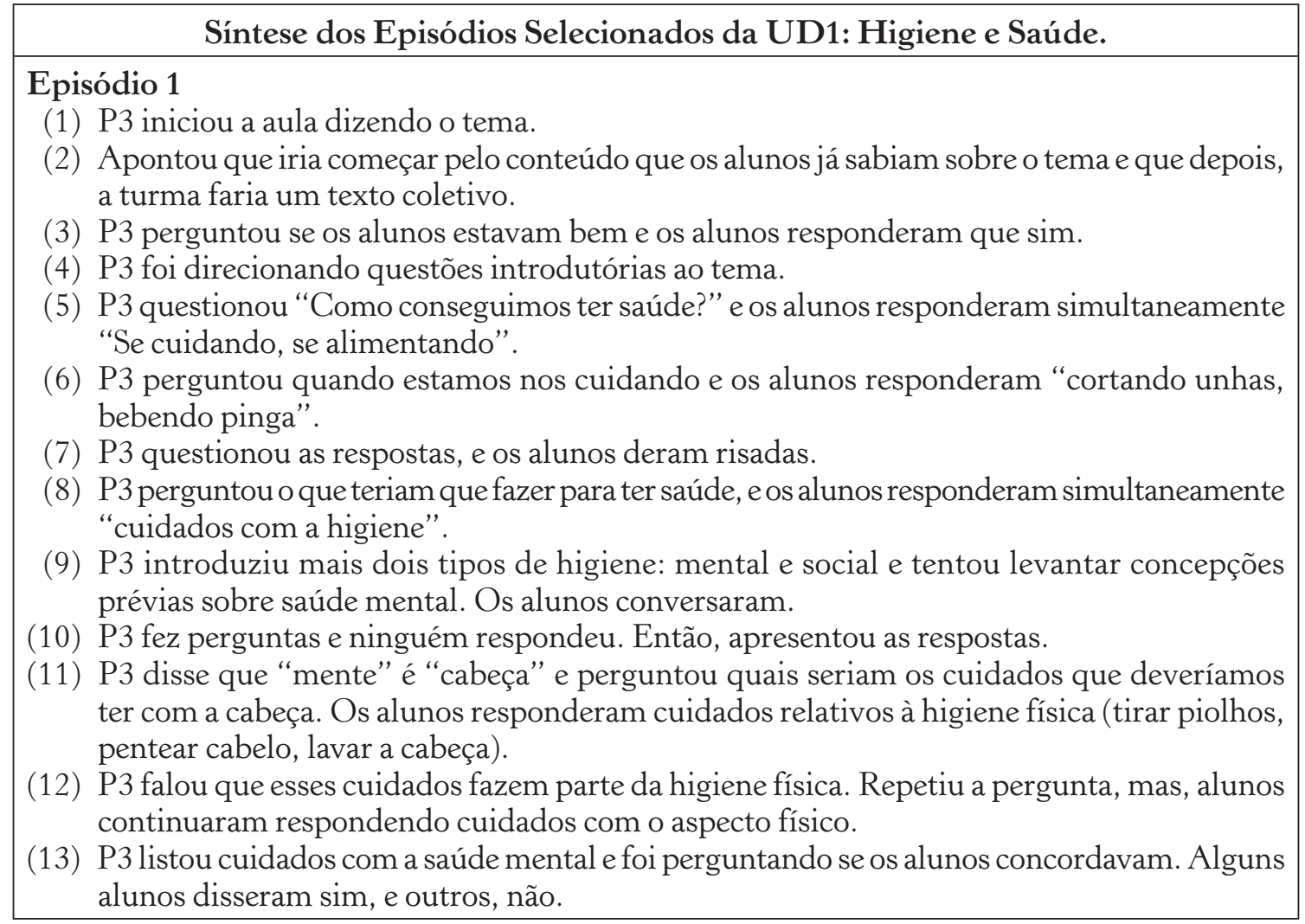


Quadro 3-Continuação.

\section{Síntese dos Episódios Selecionados da UD1: Higiene e Saúde.}

(14) P3 apresentou higiene social dando exemplos da escola.

(15) Na segunda parte do episódio 1, os alunos estavam sentados em grupo de quatro pessoas. P3 colocou na lousa o começo da atividade, fez um resumo oral da aula anterior e explicou a tarefa de recortar e diferenciar os tipos de higiene.

(16) P3 perguntou o que era higiene física, e um aluno respondeu "exercício para o corpo". P3 disse que não.

(17) P3 perguntou o que era preciso fazer para o corpo ficar limpo. Os alunos responderam "Tomar banho".

(18) P3 entregou as folhas de atividade, pediu que os alunos lessem a primeira frase em voz alta, repetiu o que estava escrito e perguntou em que tipo de higiene o exemplo poderia ser classificado. Alunos responderam corretamente.

(19) P3 deu alguns direcionamentos sobre a tarefa, e os alunos começaram a fazer.

(20) P3 passou nas carteiras explicando e atendendo individualmente. Os alunos apresentaram dúvidas, e P3 deu direcionamentos "por exclusão" ("Se não é mental, é o quê??").

(21) P3 perguntou se todos haviam entendido. Os alunos disseram que sim, e a aula terminou.

Episódio 2

(1) P3 falou que os alunos iriam elaborar um texto coletivo.

(2) Colocou o título do texto na lousa: "Saúde e Alimentação do Ser Humano" e perguntou o que os alunos iriam escrever. Os alunos falaram simultaneamente, mas não responderam sobre o tema.

(3) P3 perguntou o que eles faziam para ter saúde. Um aluno respondeu "tomar banho". P3 colocou na lousa a primeira frase do texto sem a resposta dada pelo aluno.

(4) P3 perguntou novamente o que os alunos precisariam fazer para ter saúde, e um aluno respondeu "tomar banho" novamente. P3 não colocou a resposta do aluno na lousa, e outros alunos listaram cuidados com a higiene física.

(5) P3 perguntou qual palavra poderiam colocar no texto para completar a frase. Os alunos listaram palavras, mas nenhuma era adequada na opinião de P3.

(6) A professora queria que os alunos chegassem à palavra "cuidados". P3 foi apresentando exemplos de cuidados físicos e perguntando qual palavra englobava os exemplos.

(7) Os alunos responderam simultaneamente, mas não com a palavra desejada por P3.

(8) P3 forneceu a resposta correta, escreveu na lousa, e os alunos copiaram.

(9) P3 perguntou se a higiene era importante e se era possível ter saúde sem ter higiene. Os alunos apresentaram respostas simultâneas de sim e não. P3 afirmou que era preciso ter higiene e escreveu na lousa.

(10) P3 colocou o restante do texto na lousa e pediu para os alunos terminarem listando três coisas que deveriam fazer para cuidar do corpo. Os alunos copiaram, fizeram a tarefa e levaram o caderno para P3 corrigir individualmente.

Imediatamente após o contato de P3 com os episódios selecionados da UD1, ocorreu a segunda exposição ao Roteiro 2 (Entrevista III).

$\mathrm{O}$ aspecto mais saliente na segunda exposição ao Roteiro 2 reside na manutenção das respostas anteriormente emitidas por ocasião da primeira exposição. Os dados obtidos com as duas exposições ao mesmo roteiro indicam a insuficiência do contato com os episódios extraídos das aulas ministradas por P3 na UD1 para alterar características do seu relato.

Os dois episódios selecionados concentraram ênfase em salientar as condições nas quais alguns desempenhos foram obtidos. Por exemplo, as res- 
postas "corretas" sobre a distinção entre físico e mental e a produção de um texto que foi redigido por $\mathrm{P} 3$ em oposição às respostas incorretas dos alunos. Entretanto, na Entrevista III, as respostas de P3 sobre as estratégias e os efeitos ignoraram as características das interações exibidas no vídeo, salientando a insuficiência instrucional do contato com o vídeo para informar sobre dimensões das interações entre $\mathrm{P} 3$ e os alunos possivelmente vinculados de modo funcional.

Na sequência, P3 foi exposta a um modelo de avaliação funcional descritiva elaborado pelos pesquisadores dos episódios referentes às aulas da UD1 e que consta no Quadro 4.

Quadro 4 - Modelo de Avaliação Funcional Descritiva das aulas da UD1 apresentado à P3.

Episódio 1: P3 proporcionou condições para que os alunos respondessem (a professora fez perguntas), assim, fez um diagnóstico do que os alunos sabiam ou não sobre o tema e tinha um ponto de partida. Porém, quando um aluno falou que higiene física era exercício para o corpo (resposta errada), P3 apontou que esta não era a resposta correta, não indagando o aluno e fazendo outros questionamentos para a classe. Deste modo, perdeu-se uma oportunidade de avaliar o que poderia ter contribuído para a emissão de tal resposta (identificação de relações de controle de estímulos não desejados). P3 apresentou, neste episódio, uma prática de proporcionar direcionamentos aos alunos por meio do raciocínio de exclusão. Por exemplo, "Tomar banho é mental? Não. Então é o que?”. O foco discutido esteve relacionado à exclusão ser uma forma de raciocínio que é utilizada em muitas situações, porém, apresentar um conteúdo predominantemente sob a forma de exclusão poderia aumentar a probabilidade de que, diante de um exemplo novo, os alunos não soubessem diferenciar os tipos de higiene.

Episódio 2: P3 introduziu a atividade do texto coletivo dizendo que os alunos deveriam construir o texto; colocou o título na lousa e fez um resumo da aula com os aspectos que julgou importantes. P3 proporcionou condições para os comentários gerais da sala sobre o tema, e os alunos apresentavam respostas corretas às perguntas da professora. Porém, P3 esperava que os alunos listassem os exemplos de cuidados físicos entendendo que todos estão na classe de "cuidados". Ou seja, a professora esperava que os alunos respondessem além da simples reprodução dos conceitos que ela já havia apresentado. Os alunos começaram apresentando alta frequência de respostas, que foram se esvanecendo durante o transcorrer da aula. Isso possibilitou a resposta da professora de colocar o texto na lousa da maneira que achava mais adequada, com informações que acreditava serem importantes. Desta maneira, apresentou-se a hipótese à professora de que ela poderia ter induzido os alunos ao erro, já que apresentou uma tarefa com exigências que excediam as condições previamente oferecidas. Ao final do texto, os alunos deveriam listar cuidados com o corpo, que eram os exemplos que os alunos já tinham dado no começo da aula, e, mesmo já tendo respondido anteriormente, os alunos apresentavam dúvidas. Diante das condições propiciadas pela professora nesta atividade, os alunos manifestaram dependência em relação às respostas de P3. Durante a discussão deste foco, P3 afirmou que os alunos apresentam insegurança em decorrência de estarem em processo de alfabetização, tendo dificuldade na escrita, e não porque achavam que suas respostas estavam erradas. Ou seja, P3 acredita que a insegurança dos alunos não seja em relação ao conteúdo curricular (por exemplo, a dúvida não é referente a se tomar banho é ou não importante; eles sabem que é; a dúvida é se "tomar banho" está escrito da maneira correta). P3 afirma: "A insegurança é em tudo mesmo. Eles não acreditam neles mesmos. A insegurança não é em relação ao conteúdo curricular, porque eles tinham respondido tudo antes. Mas é em relação à escrita". 
A seguir, ocorreu a exibição dos episódios das aulas da UD2 à P3 e, em seguida, P3 apresentou oralmente uma análise de tais episódios.

P3, ao interpretar as interações, ressaltou o mérito da oralidade, enquanto estratégia de ensino, para produzir manifestações dos alunos. Para o modelo de avaliação funcional descritiva, a ênfase deveria recair na possibilidade de identificação dos possíveis determinantes dessas manifestações. Assim, as questões repetidas elaboradas por P3 certamente estimularam a manifestação seletiva de alguns alunos. Mas as manifestações dos alunos indicavam a insuficiência dos recursos disponibilizados por P3 para a compreensão do conceito de "origem". Ao repetir questões sobre as origens, P3 priorizou a produção de respostas finais e não a descrição dos aspectos considerados para a emissão das respostas, ou seja, das possíveis relações de controle ou de dependência que as respostas mantinham com determinados aspectos da escolarização dos alunos que tornavam improváveis as respostas: "vegetal", "animal" e "mineral".

Nas suas análises, P3 insistiu em priorizar uma interpretação de medidas de desempenho ("identificar a origem", "perceber variações"). Na realidade, os alunos de $\mathrm{P} 3$ produziram medidas de identificação e de percepção praticamente somente após $\mathrm{P} 3$ expor explicitamente as respostas previstas como corretas, ou expor dicas detalhadas sobre tais respostas. As condições exibidas nos episódios prescindem de interações que atestaram a emissão das respostas previstas na ausência de dicas de P3.

Em acréscimo, P3 insistiu em atribuir as dificuldades exibidas pelos alunos a problemas de alfabetização, sendo que tais dificuldades foram minimizadas, principalmente, pelas manifestações dos alunos, a saber, pela emissão das respostas previstas diante da oralidade recorrente de P3.

A seguir, P3 foi exposta a uma versão escrita de um modelo de avaliação funcional descritiva de tais episódios, elaborado pelos pesquisadores e disposto no Quadro 5.

O modelo de avaliação funcional descritiva elaborado pelos pesquisadores destacou que medidas indicativas de dificuldades sugerem que algumas respostas foram ocasionadas diante de determinados fatores, aspectos, informações, ou seja, determinadas respostas sustentam possíveis relações de dependência (ou de controle) inadequadas com informações e dimensões do contexto no qual elas foram solicitadas. Assim, por exemplo, ao responder "salsicha" diante de um questionamento sobre alimentos sau- 
Quadro 5 - Modelo de Avaliação Funcional Descritiva dos episódios (UD2) apresentado à P3.

Episódio 1: Foram relatados à docente $\mathrm{P} 3$ que os questionamentos realizados propiciaram condições para que os alunos respondessem oralmente sobre seus conhecimentos prévios. Esta prática de ensino garantiu uma participação seletiva dos alunos na sala, mas, ao mesmo tempo, dificultou a visibilidade de possíveis relações de determinação para tais respostas, ou seja, a que atribuir tais respostas. Deste modo, também ficou prejudicada a interpretação se ocorreu compreensão dos conceitos em relação aos alunos que não participaram. Diante das perguntas, os alunos responderam corretamente nomes de alimentos e buscavam discriminação entre saudável e não saudável. Ocorre que P3 não explicou o conceito "saudável", pressupondo que os alunos já o soubessem. Considerou os exemplos mencionados pelos alunos, mas não fez questionamentos entre o que era ou não saudável. Tal prática gerou respostas de indagação nos alunos. No entanto, não permitiu identificar o que poderia ser responsável por tais eventos. Também não permitiu visibilidade sobre o que os alunos levaram em consideração ao se comportar em alguns questionamentos, quando os alunos respondiam "sim" e "não". Em alguns casos, P3 considerou que as respostas incorretas dos alunos eram gracejos. Tal consideração impediu P3 de avaliar o desempenho e compreensão dos alunos em relação ao tema. Foi salientado ainda à P3 que mesmo as respostas corretas poderiam ter sido emitidas, entre outras, por imitação e/ou memorização.

Episódio 2: O foco deste episódio foram: (a) o comportamento dos alunos de responder diante das perguntas feitas por P3; (b) a frequente manifestação de dúvidas por meio de indagações dos alunos à $\mathrm{P} 3$ imediatamente após a explicação do conteúdo. Ambos poderiam estar funcionalmente relacionados à manutenção das práticas de $\mathrm{P} 3$ em fazer perguntas "exploratórias" sobre o tema da aula e, ao mesmo tempo, fornecer dicas que continham respostas corretas. Diante de respostas incorretas dos alunos, $\mathrm{P} 3$ reformulou as perguntas. No entanto, se as respostas dos alunos persistiram divergentes e/ou incorretas, P3: (a) forneceu, mediante pistas (por exclusão), a resposta correta; (b) fez relações entre os alimentos e suas origens (as relações feitas por P3 nem sempre estiveram corretas); (c) ignorou e/ou não comentou respostas incorretas ou inconsistentes com o assunto. Diante dos questionamentos dos alunos durante a resolução das atividades, P3 forneceu dicas que continham as respostas corretas, isto fez com que os alunos fizessem mais e mais perguntas. Esse comportamento de perguntar dos alunos poderia estar relacionado ao fato de que: (a) os alunos realmente não entenderam o conteúdo exposto por $\mathrm{P} 3$, isto é, como classificar os alimentos de acordo com sua origem; (b) queriam se assegurar da correção de suas respostas; ou mesmo (c) buscavam respostas prontas nas pistas fornecidas pela docente P3. Tais estratégias de ensino não permitiram à docente visibilidade sobre o que os alunos compreenderam do subtema classificação dos alimentos.

Episódio 3: Ocorreu reincidência do repertório de $\mathrm{P} 3 \mathrm{em}$ questionar os alunos depois de os alunos fornecerem as respostas. P3 forneceu pistas que levaram à resposta correta por meio do raciocínio de exclusão. Esse modelo de ensino adotado por P3 também não forneceu medidas sobre a aprendizagem dos alunos. Pode-se supor que os alunos, ao responder, o fizeram com autonomia seguindo os mesmos raciocínios de exclusão utilizados por P3. Ou, ao contrário, responderam em função das dicas fornecidas pela docente, e isto acabou gerando proximidade e relação de dependência entre o aluno saber responder corretamente e buscar constantemente as dicas fornecidas pela docente.

Episódio 4: Durante a correção dos exercícios na lousa, novamente P3 fez perguntas aos alunos, e eles responderam oralmente. Outra vez, quando as respostas eram corretas, P3 as considerou transcrevendo-as ou não na lousa. Se, ao contrário, eram respostas divergentes ou incorretas (segundo o critério adotado pela professora), P3 reformulou as perguntas. Diante de novas respostas incorretas, a docente as ignorou e transcreveu na lousa as respostas corretas. Do mesmo modo, não foi possível avaliar se ocorreu ou não compreensão pelos alunos sobre o conceito "alimentos saudáveis e não saudáveis" ou ao menos estimar uma proximidade entre o que P3 pretendeu ensinar e o que de fato ensinou. Isto ocorreu, pois foi possível constatar que alguns alunos não relacionaram, por exemplo, propriedades nutricionais dos alimentos, quantidades diárias ingeridas, necessidades diárias, seleção de alimentos saudáveis e hábitos nutricionais. 
dáveis ou ao responder "mercado" diante de indagações sobre a origem do tomate, os alunos evidenciam que suas respostas estão baseadas, ou seja, se mostram dependentes ou sob controle de dimensões ou aspectos distintos daqueles previstos por P3. Nestes termos, a oralidade de P3 constitui-se em condição indutora de respostas que explicitaram as diferenças de fontes de controle, mas não garantiram acesso a estas. Diante da manifestação das respostas incorretas, P3 as atribuiu a fatores externos às interações que ela proporcionou, ou impôs as respostas previstas ou forneceu dicas recorrentemente que tornavam as respostas corretas altamente prováveis.

Assim, a emissão das respostas previstas pelos alunos, no âmbito de uma interpretação baseada no modelo de avaliação funcional descritiva, estaria vinculada com a disposição de estratégias que, prescindindo da identificação das fontes de controle incorretas, estabeleceram diretamente quais eram as respostas corretas sob dadas condições (indagações ou partes da exposição do conteúdo).

A última etapa da pesquisa foi iniciada com o registro das aulas da UD3 e, em seguida, a seleção e a edição dos respectivos episódios.

Após a exibição dos episódios das aulas da UD3, uma síntese das respostas fornecidas por P3 na entrevista final consta no Quadro 6.

Quadro 6 - Síntese das respostas de P3 ao Roteiro 3 (aulas UD3).

\begin{tabular}{|c|c|c|c|}
\hline $\begin{array}{c}\text { Estratégias } \\
\text { utilizadas por P3 }\end{array}$ & $\begin{array}{l}\text { Objetivos das } \\
\text { estratégias }\end{array}$ & $\begin{array}{l}\text { Desempenho } \\
\text { esperado dos alunos }\end{array}$ & $\begin{array}{c}\text { Efeitos conseguidos } \\
\text { com os alunos }\end{array}$ \\
\hline $\begin{array}{l}\text { Trabalhar de modo } \\
\text { diferenciado, pois } \\
\text { trata-se de uma sala } \\
\text { de recuperação de } \\
\text { ciclo; } \\
\text { trabalhar } \\
\text { intensamente com } \\
\text { leitura e escrita; } \\
\text { priorizar a } \\
\text { alfabetização. }\end{array}$ & $\begin{array}{l}\text { Preparar o aluno para } \\
\text { o Saresp; } \\
\text { desenvolver o } \\
\text { raciocínio lógico; } \\
\text { desenvolver leitura } \\
\text { e interpretação de } \\
\text { problemas, saber } \\
\text { interpretar tabelas } \\
\text { e saber descrever } \\
\text { observações } \\
\text { realizadas em mapas } \\
\text { ou desenhos; } \\
\text { verificar se os alunos } \\
\text { tinham os conceitos } \\
\text { de quilômetro e } \\
\text { metro e se eles sabiam } \\
\text { convertê-los entre si. }\end{array}$ & $\begin{array}{l}\text { Desenvolver o } \\
\text { raciocínio lógico; } \\
\text { responder } \\
\text { às equações } \\
\text { corretamente; } \\
\text { saber ler, interpretar } \\
\text { e responder um } \\
\text { exercício matemático; } \\
\text { saber fazer } \\
\text { transformações entre } \\
\text { quilômetro e metro. }\end{array}$ & $\begin{array}{l}\text { "O comportamento } \\
\text { deles, desde o começo } \\
\text { do ano, mudou, } \\
\text { as notas foram } \\
\text { boas, a vontade de } \\
\text { fazer as atividades } \\
\text { de cálculo. Eles } \\
\text { superaram a maioria } \\
\text { das dificuldades. } \\
\text { Nas atividades } \\
\text { do portfólio, deu } \\
\text { para ver que eles } \\
\text { melhoraram." } \\
\text { Os alunos atingiram } \\
\text { os objetivos, } \\
\text { "A maioria fez, } \\
\text { entenderam, fizeram } \\
\text { as contas". }\end{array}$ \\
\hline
\end{tabular}


Nas aulas ministradas nas UD1 e UD2, foram reincidentes ações de P3 que não permitiam o acesso aos fatores possivelmente responsáveis ou dos quais dependiam ou derivavam as respostas incorretas expressas nas manifestações dos alunos.

Nas aulas da UD3, para as respostas corretas, tanto quanto para as incorretas, $\mathrm{P} 3$ indagou os alunos sobre o que eles consideravam para emitir as respostas apresentadas, ou, em outros termos, em que se baseavam as respostas emitidas para os questionamentos da professora. Possivelmente, a ocorrência de tais indagações por $\mathrm{P} 3 \mathrm{em}$ sala de aula esteja funcionalmente vinculada com as análises expressas nos modelos de avaliação funcional descritiva, elaborados pelos pesquisadores e exibidos à $\mathrm{P} 3$ nas etapas anteriores.

Contudo, na aula da UD3, emitir tais questionamentos não se constituiu em condição suficiente para a produção de medidas previstas pelos alunos de $\mathrm{P} 3$ quanto à indicação de possíveis relações de controle envolvendo respostas corretas e incorretas. E diante do insucesso inicial na produção de tais medidas, constatou-se que $\mathrm{P} 3$ voltou a emitir as respostas que os alunos deveriam expressar, bem como a fornecer as dicas que tornavam as respostas previstas altamente prováveis, sem que a emissão delas fosse observada na ausência das dicas.

Os principais resultados obtidos na investigação relatada neste capítulo sobre formação de professores que ensinam conteúdos curriculares de Ciências nas séries iniciais salientaram que a aprendizagem de repertórios de ensino inferida das ações de P3 na aula da UD3 sugere relações de independência entre, de um lado, mudanças no agir em sala de aula e, de outro, o relato da docente sobre a sua atuação em sala de aula. Tal independência pode também ser inferida nas análises comparativas de P3 sobre as aulas ministradas nas três unidades didáticas. Ao atribuir as mudanças de desempenho dos alunos na aula ministrada na UD3, praticamente de modo exclusivo às características dos conteúdos ministrados, $\mathrm{P} 3$ evidencia a insuficiência dos procedimentos adotados para vincular as mudanças no agir em sala de aula com a descrição dessas ações em termos consistentes com o modelo de avaliação funcional descritiva.

O desenvolvimento de estratégias metodológicas que priorizem a eliminação de tal independência, favorecendo o desenvolvimento de aprendizagens profissionais da docência, nas quais ações efetivamente dispostas e 
análises descritivas das interações resultantes sustentem correspondências consistentes, apresenta-se como questão de pesquisa que orienta programas de investigação no âmbito da formação de professores responsáveis pelo ensino de Ciências nas séries iniciais.

\section{Referências bibliográficas}

BAUM, W. Compreender o Behaviorismo: Ciência, Comportamento e Cultura. Porto Alegre: ArtMed Editora, 1999.

BRASIL, Parâmetros Curriculares Nacionais: Ciências Naturais. 1o e 2ํㅡㄴ. nistério da Educação. Secretaria de Educação Fundamental, 3. ed., Brasília: A Secretaria, 126 p., 2000.

CARVAlHO, A. M. P. Critérios Estruturantes para o Ensino de Ciências; In: CARVAlHO, A. M. P. (Org.). Ensino de Ciências - Unindo a Pesquisa e a Prática. São Paulo, Editora: Pioneira Editora Thomson, pp.1-17, 2004.

FOX, J.; DAVIS, C. Functional behavior assessment in schools: Current research findings and future directions. Journal of Behavioral Education, 14 (1), pp.1-4, 2005.

GIL-PÉREZ, D.; CARVALHO, A. M. P.; Formação de professores de ciências: tendências e inovações. Questões da Nossa Época. 5. ed. São Paulo: Cortez, 2001.

GOVERNO DO ESTADO DE SÃO PAULO, Versão Preliminar Para Apreciação da Rede Pública Estadual; Ciências da Natureza - Ciclo I. In: Ensino Fundamental; Expectativas de Aprendizagem; Coordenadoria de Estudos e Normas Pedagógicas/CENP. Equipe do Ciclo I - Ensino Fundamental, 2008.

LONGHINI, M. O conhecimento do conteúdo científico e a formação do professor das séries iniciais do Ensino Fundamental. Investigações em Ensino de Ciências, v.13, n.2, pp.241-253, 2008.

PAIXÃO, M. F.; CACHAPUZ, A. La enseñanza de las ciencias y la formación de profesores de enseñanza primaria para la reforma curricular: de la teoría a la práctica. Ensenãnza de las Ciencias, v.17, n.1, pp.69-77, 1999.

PEREIRA, J. E. D.; A Pesquisa dos Educadores Como Estratégia para Construção de Modelos Críticos de Formação Docente. In: PEREIRA, J. E. D. \& ZEICHNER, K. M. (Orgs.). A pesquisa na formação e no trabalho docente. Belo Horizonte: Autêntica, (Trajetórias, 9). 2002. 200p.

PEREIRA, M. E. M.; MARINOTTI, M.; LUNA, S. V.; O compromisso do professor com a aprendizagem: Contribuições da Análise do Comportamento. In: HÜBNER, M. M. C.; MARINOTTI, M. (Orgs.). Análise do Comportamento para a Educação: Contribuições Recentes, Santo André: ESETec Editores Associados, pp.11-32, 2004. 
SASSERON, L.; CARVALHO, A. M. P. Almejando a alfabetização científica no Ensino Fundamental: A proposição e a procura de indicadores do processo. Investigações em Ensino de Ciências, v.13, n.3, pp.333-352, 2008.

ZANOTTO, M. L. B. Formação de professores: a contribuição da análise do comportamento. São Paulo. EDUC/FAPESP, 2000. 183 p.

ZEICHNER, K. M. Uma Análise Crítica Sobre a "Reflexão" como Conceito Estruturante na Formação Docente. Educação \& Sociedade, Campinas, vol. 29, n.103, p.535-554, maio/ago. 2008. 



\title{
12 \\ A FORMAÇÃO DE PROFESSORES: UMA REVISÃO DAS ÚLTIMAS DÉCADAS EM REVISTAS BRASILEIRAS dA ÁREA de Educação Matemática
}

\author{
Marinez Meneghello Passos ${ }^{1}$ \\ Roberto Nardi \\ Sergio de Mello Arruda ${ }^{3}$
}

\section{Introdução}

Nesta pesquisa, tem-se como intenção compreender, por meio dos artigos publicados em periódicos da área de Educação Matemática no Brasil, o que é o campo ${ }^{4}$ formação de professores, quais são os sentidos de formação docente presentes nesses trabalhos publicados e que movimentos esses sentidos fizeram nessas três décadas.

Na sequência, apresentam-se algumas informações a respeito do acervo investigativo.

- Boletim do grupo de estudos e pesquisas em Educação Matemática Gepem (1976-2007). http://www.gepem.ufrrj.br/

- Boletim de Educação Matemática - Boletim do grupo de estudos e pesquisas em Educação Matemática - Bolema (1985-2007). http:// www.rc.unesp.br/igce/matematica/bolema/

1 Docente da Universidade Estadual de Londrina (UEL). Doutora pelo Programa de Pós-Graduação em Educação para a Ciência, Universidade Estadual Paulista Júlio de Mesquita Filho (Unesp), campus de Bauru.

2 Professor-adjunto do Departamento de Educação. Grupo de Pesquisa em Ensino de Ciências, Programa de Pós-Graduação em Educação para a Ciência, Faculdade de Ciências, campus de Bauru, Universidade Estadual Paulista Júlio de Mesquita Filho (Unesp).

3 Universidade Estadual de Londrina (UEL).

Apoio Financeiro do Conselho Nacional de Desenvolvimento Científico e Tecnológico (CNPq).

4 Adotou-se o termo campo como "área em que se desenvolve certa atividade", neste caso, pesquisas, reflexões e/ou projetos relativos à formação do professor. 
- Educação Matemática em Revista - EMR (1993-2007). http://www. sbem.com.br/index.php?op=EMR

- Zetetiké - ZETETIKÉ (1993-2007). http://www.cempem.fae.unicamp.br/zetetike.htm

- Educação Matemática Pesquisa - EMP. (1999-2007). http://www. pucsp.br/pos/edmat/revista.html

Para a escolha das revistas analisadas, utilizou-se o Sistema de Avaliação e Qualificação da Coordenação de Aperfeiçoamento de Pessoal de Nível Superior - Capes, o Qualis, selecionando periódicos da área Educação Matemática com avaliação níveis A ou B e circulação nacional $(\mathrm{N})$ ou internacional (I) ${ }^{5}$.

O Quadro 1 traz a quantidade de revistas, de artigos de cada revista e a quantidade de artigos que identificou-se e assumiu-se como do campo da formação de professores. Na última coluna, apresenta-se a percentagem de artigos relacionados à temática em questão.

Quadro 1 - Informações relativas à quantidade de revistas e de artigos do campo da formação de professores - período considerado 1976/2007.

\begin{tabular}{|l|c|c|c|c|}
\hline $\begin{array}{c}\text { Sigla referente ao } \\
\text { nome da revista / } \\
\text { Ano de início da } \\
\text { publicação }\end{array}$ & $\begin{array}{c}\text { Total de } \\
\text { revistas } \\
\text { editadas até o } \\
\text { ano de 2007 }\end{array}$ & $\begin{array}{c}\text { Total de } \\
\text { artigos }\end{array}$ & $\begin{array}{c}\text { Total de } \\
\text { artigos sobre } \\
\text { formação de } \\
\text { professores }\end{array}$ & $\begin{array}{c}\text { Percentagem } \\
\text { aproximada de } \\
\text { artigos referentes } \\
\text { à formação de } \\
\text { professores }\end{array}$ \\
\hline GEPEM/1976 & 51 & 309 & 42 & $14 \%$ \\
\hline BOLEMA/1985 & 32 & 202 & 27 & $13 \%$ \\
\hline EMR/1993 & 21 & 172 & 45 & $26 \%$ \\
\hline ZETETIKÉ/1993 & 25 & 143 & 50 & $35 \%$ \\
\hline EMP/1999 & 19 & 76 & 12 & $16 \%$ \\
\hline TOTAL & 148 & 902 & 176 & $20 \%$ \\
\hline
\end{tabular}

Como pode ser observado no quadro, o acervo pesquisado é composto por 148 revistas publicadas entre em um período de edição de 32 anos 1976/2007.

Ao observar cada grupo de revista, pode-se verificar também que, em geral, as mais recentes, cujas publicações tiveram seu início na década de 1990 e no princípio deste século, são as que mais publicam sobre formação

5 Durante o desenvolvimento da pesquisa, esse sistema estava em processo de atualização, por isso usou-se o Qualis vigente no ano de 2007. 
do professor: Zetetiké (40\%), datada de 1993; EMR (26\%), datada de 1993; EMP (16\%), datada de 1999; em contraposição àquelas que tiveram suas publicações iniciadas nas décadas de 1970 e 1980.

Adotou-se por referencial as análises textuais, que segundo Navarro e Díaz (1999) possuem como foco de estudo as mensagens, a linguagem, o discurso, mesmo que seu corpus ${ }^{6}$ não seja necessariamente verbal. Para o desenvolvimento desta investigação, aceita-se a análise textual e, por conseguinte, a análise de conteúdo, como método de investigação para este campo de pesquisa que constantemente se depara com uma diversidade muito grande de problemas, justificando que suas características de adaptação fazem com que se acomodem de forma harmônica na exploração qualitativa das mensagens e das informações.

A análise de conteúdo constitui uma metodologia de pesquisa usada para descrever e interpretar o conteúdo de toda classe de documentos e textos. Essa análise, conduzindo a descrições sistemáticas, qualitativas ou quantitativas, ajuda a reinterpretar as mensagens e a atingir uma compreensão de seus significados num nível que vai além de uma leitura comum (Moraes, 1999, p.9).

Pautando-se nas primeiras análises oportunizadas por esse referencial, construiu-se de forma descritiva e analítica os movimentos da pesquisa, mostrando o processo de seleção e aquisição do acervo e as primeiras análises sustentadas pelas palavras-chave (Passos et al., 2005). Na sequência, teve-se a constituição do corpus (Passos et al., 2006 e 2008) sobre e sob o qual se desenvolve esta investigação e que para este momento destacam-se diversos outros de seus resultados.

As considerações aqui trazidas tiveram como antecedentes investigativos a construção das unidades de pesquisa e de análise, que foram estruturadas sobre três eixos:

- Os problemas e/ou os objetivos de pesquisa que geraram os artigos (Passos et al., 2007a).

- As considerações, reflexões e/ou conclusões dessas pesquisas relativas à formação inicial (Passos et al., 2007b).

- As considerações, reflexões e/ou conclusões dos processos investigativos sobre o campo de formação de professores em geral.

6 O conjunto dos documentos tidos em conta para serem submetidos aos procedimentos analíticos (Bardin, 2004, p.90). 
Do processo interpretativo dessas unidades de pesquisa foi possível evidenciar diversos sentidos, dados pelos autores dos artigos, sobre o professor e perceber que as "falas" convergiam para dois focos bem evidentes "o que o professor é" - facilitador, mediador, tomador de decisões entre outros -, e "o que o professor deve" - participar, possuir, preocupar-se, agir, atuar entre outros. Naquela ocasião, construiram-se dois quadros com essas entradas, e alguns resultados podem ser observados em Passos et al. (2009).

$\mathrm{Na}$ continuidade, procura-se categorizar as informações verificando o movimento relativo aos sentidos adotados nos artigos para "formação" e ao final tecer interpretações e conclusões. Ao retomar-se o metatexto ${ }^{7}$, buscando pela unitarização de algumas informações, foram construídas outras unidades de análise que eram representativas do que os autores dos artigos consideravam por "formação" - os deveres e as funções da formação; o que se espera do professor dentro da proposta formativa; a ênfase aos conteúdos matemáticos e pedagógicos; destaques para as práticas e as habilidades nesse processo; propostas de cursos; indicativos de como estruturar uma proposta de formação; pareceres sobre as licenciaturas; conceitos e denominações utilizados na composição dos artigos; o papel da universidade perante a formação; o que se espera dos formadores e, por fim, faltas e lacunas detectadas e apontadas pelos autores dos documentos em análise.

Neste artigo, traz-se uma análise integrada dos diversos resultados já publicados (desta pesquisa que se desenvolve desde o ano de 2005) e dos últimos avanços possibilitados pela construção dessas unidades de pesquisa e de análise relacionadas no parágrafo anterior.

No momento, procura-se observar convergências e divergências, consonâncias e dissonâncias - cristalizadas em movimentos e tendências - mostradas nessas três décadas de publicação dos pesquisadores e colaboradores da área de Educação Matemática no Brasil, que se dedicam a investigações relativas ao campo da formação de professores.

\section{As escolhas, o que se assume e os referenciais}

Quanto aos critérios de seleção dos artigos utilizados, tem-se ciência de que podem ter sido negligenciados ou deixados à margem alguns artigos,

7 Texto no qual o pesquisador comunica os pareceres sobre o objeto de pesquisa. 
entretanto, acredita-se que os que foram selecionados contribuíram com a compreensão do que se buscava, mostrando um movimento da área com relação ao campo da formação de professores. Levanta-se, ainda, no tocante às problemáticas, que a Educação Matemática encontra-se em uma interface e tem também espaço de publicação junto à Educação, e os periódicos dessa área não foram, nesta investigação, acessados para estudo e análise.

Busca-se, para constituir um balizamento sobre o que considerar relativo ao campo da formação de professores, precedentes da área de Educação Matemática no Brasil. Naquela ocasião, pautou-se em levantamentos realizados e apresentados em Fiorentini et al. (2002, p.141-142), para um período que vai de 1978 a 2002, em que 112 teses e dissertações são analisadas. Esses autores destacam onze "subfocos" relativos à formação: para a formação inicial - estudos de programas e cursos; prática de ensino e estágio supervisionado; estudos de outras disciplinas; atividades extracurriculares; formação, pensamento e prática de formadores; outras questões específicas da formação docente - para a formação continuada -, modelos, programas, propostas e projetos; cursos de atualização e especialização; investiga a própria prática do formador; grupos ou práticas colaborativas; iniciação e evolução profissional do professor.

Na pesquisa de Ferreira (2003) pôde-se observar resultados de um trabalho que teve como objeto 160 pesquisas, provenientes de teses e dissertações, sobre formação e desenvolvimento profissional de professores de Matemática. Nele, a autora sintetiza que, a partir da segunda metade da década de 1970, podem-se perceber três categorias de pesquisa - estudos diagnósticos dos cursos de licenciatura; estudos comparativos relacionando características do professor e desempenho do aluno; estudos que avaliam as propostas de treinamento de professores (p.27). A partir da década de 1980, ocorrem mudanças nesse quadro investigativo, e as pesquisas passam a focar os cursos de licenciatura em processos avaliativos; a relação dos professores com as novas tecnologias; concepções e percepções dos professores sobre os contextos educacionais e o conhecimento matemático; a prática pedagógica dos professores (p.28). Nos anos finais da década de 1980, o professor passa a ser visto como alguém que pensa e que reflete sobre sua prática (p.29), e entra-se na década de 1990 tendo como foco investigativo "as cognições dos professores acerca de sua própria formação" (p.29). As compreensões iniciais que daí emergem conduzem os pesquisadores a se 
interessarem pelo que os professores pensam sobre sua própria formação e como percebem e avaliam seu desenvolvimento profissional.

Tem-se, também, a pesquisa desenvolvida por Melo (2006), quando a autora procura discorrer sobre a seguinte questão: "Que tendências temáticas apresentam, historicamente, as teses e dissertações em Educação Matemática produzidas e defendidas na Unicamp no período de 1976 a julho de 2003?" (p.43).

Acessa-se e estuda-se, ainda, o que André et al. (1999) apresenta a respeito da formação de professores, onde busca uma síntese integrativa do conhecimento relativo a esse campo em um período que vai de 1990 a 1998 e que tem como objetos de estudo e análise diversas produções: dissertações e teses de programas de pós-graduação em Educação; artigos publicados em periódicos da área de Educação e pesquisas apresentadas em plenárias e grupos de trabalhos da Associação Nacional de Pós-graduação e Pesquisa em Educação - ANPEd. Entre os resultados apresentados por essas pesquisadoras estão:

A análise do conteúdo de 115 artigos publicados em dez periódicos nacionais, de 284 dissertações e teses produzidas nos programas de pós-graduação em educação e de 70 trabalhos apresentados no GT Formação de Professores da ANPEd, na década de 1990, permitiu identificar uma significativa preocupação com o preparo do professor para atuar nas séries iniciais do Ensino Fundamental. Permitiu ainda evidenciar o silêncio quase total em relação à formação do professor para o Ensino Superior, para a educação de jovens e adultos, para o ensino técnico e rural, para atuar nos movimentos sociais com crianças em situação de risco (André et al, 1999, p.309).

As autoras relatam ainda que, apesar de haver a indicação de que teoria e prática precisam estar articuladas, "a análise das pesquisas evidenciou um tratamento isolado das disciplinas específicas e pedagógicas” (p.309). E concluem:

Finalmente, as diversas fontes analisadas mostram um excesso de discurso sobre o tema formação docente e uma escassez de dados empíricos para referenciar práticas e políticas educacionais (André et al., 1999, p.309).

Outra referência que contribuiu com as reflexões para o desenvolvimento desta investigação foi André (2002), onde se observam diversos levantamentos e balizamentos estruturados segundo as teorias e conceitos 
do Estado da Arte e do Conhecimento aplicados sob uma diversidade de documentos que versam a respeito da formação de professores no Brasil.

Em resumo, todos esses trabalhos contribuíram com a intenção de buscar de forma sintetizada uma relação de temas que contassem a história e, por conseguinte, caracterizassem de forma sumarizada os artigos em estudo nesta fase da investigação que por progressão pudessem caracterizar o campo da formação de professores para a área de Educação Matemática.

Após o estudo dos referenciais apresentados anteriormente e do acervo constituído para o encaminhamento desta investigação, pôde-se concluir que muito se pesquisa sobre o campo formação de professores no Brasil, e, ainda, foi possível observar a "importação" de diversos conceitos de outras áreas disciplinares e de pesquisa para a área de Educação, e, portanto, para o campo investigativo da formação de professores. Observa-se também que há uma grande divergência na adoção desses referenciais, e é neste movimento divergente que começa a se constituir o perfil do campo de formação do professor no Brasil.

\section{Para além dos dados ${ }^{8}$}

Quando as palavras-chave são assumidas como disparadores do processo investigativo, dá-se voz aos autores dos artigos para comporem a listagem de palavras que indicariam "o que mais se pesquisava ou tinham pesquisado nessas três décadas em avaliação". A formação de professores evidenciou-se, e uma lista de palavras-chave ${ }^{9}$ que baliza esse campo de pesquisa foi gerada.

Acredita-se que este tenha sido um dos primeiros resultados desta pesquisa e poderia contribuir com a caracterização do campo formação de professores de Matemática.

8 Agradecemos à professora doutora Maria Aparecida Viggiani Bicudo pela sugestão do título e pela forma com que as considerações desta seção estão apresentadas.

9 Em ordem alfabética temos - Currículo; Desenvolvimento profissional; Formação; Formação continuada de professores; Formação de professores; Formação de professores contextualizada; Formação de professores das séries iniciais; Formação de professores de matemática; Formação docente; Formação inicial; Formação inicial de professores; Licenciatura; Novas concepções pedagógicas; Práticas (docentes); Professor de Matemática; Professor investigador; Professor reflexivo; Professores de Matemática; Reflexão sobre a prática; Saber docente; Teoria e prática. 
Outro ponto perceptível foi o de que os primeiros artigos, considerando um movimento de leitura 1976-2007, não traziam definições, conceitos ou explicações do que era "formação do professor". Somente após alguns anos de publicação sobre o tema é que esclarecimentos a respeito do que se assumia por formação do professor de Matemática começaram a ficar mais evidentes.

A licenciatura foi um desses primeiros focos investigativos e apresenta-se por meio da avaliação de curso, de propostas de estruturação curricular, de sugestão de disciplinas, dos conteúdos matemáticos que precisam ser apresentados e desenvolvidos com os licenciandos e por meio das discussões a respeito de teoria e prática.

Somente a partir de 2000 é que as pesquisas - com os licenciandos e seus formadores - passaram a focar o ensino de graduação, via concepções, valores, crenças, construção dos saberes, posturas reflexivas e críticas (dos estudantes e de seus mestres) em situações de ensino e de aprendizagem.

A formação continuada começa a ser discutida nos artigos uma década após a licenciatura ter se consolidado como foco de pesquisa e, da mesma forma que a licenciatura - sem definição, sem conceito ou explicação evidente -, apresenta-se inicialmente por meio das intervenções realizadas em sala de aula e dos cursos oferecidos aos professores em atividade.

Posteriormente a esse movimento é que a formação continuada passa a ser considerada por meio de algumas propostas teóricas, entre as quais se relacionam: o Método de Projetos; a Reflexão Distanciada; a Pesquisa-intervenção; as situações Construtivo-colaborativas; as Ações Pedagógicas Investigativas; as Ações Solidárias; a Pesquisa-ação; o Trabalho Colaborativo.

Com relação às propostas de formação, pode-se perceber que são planejadas segundo diversas formas de abordagem. Iniciam-se como uma receita de "como ensinar determinados conteúdos", passam pelo levantamento de concepções de professores e alunos sobre alguns conteúdos e movem-se, atualmente, na direção de levar o professor a pesquisar a própria prática, para que identifique quais seriam as propostas mais viáveis, para suas diferentes turmas, no desenvolvimento dos conteúdos matemáticos.

Com relação ao parágrafo anterior, uma visão resumida e compacta (desse movimento), seria: a passagem de um contexto de "treinamento do professor" para "um convite à reflexão"; um movimento que deixa de se importar, unicamente, com a "racionalidade técnica" e passa a ver uma possível solução para amenizar os problemas no contexto educativo via "formação de um professor pesquisador". 
Destaca-se que as questões curriculares foram frequentemente pesquisadas quando a temática é formação inicial - licenciatura em Matemática ou graduação em Pedagogia. Percebe-se esse movimento desde a década de 1980, contudo, houve um período em que saiu de cena, mas voltou a ser considerado nas pesquisas e nas reflexões apresentadas nos artigos, novamente, após o ano 2000.

A formação Matemática e/ou os conteúdos matemáticos e/ou o conhecimento matemático também foram focados nas considerações de diversos pesquisadores. Nesse período de 30 anos, nota-se, pelo apresentado nos relatos e nos resultados de pesquisa, que o conteúdo matemático tem seu espaço marcado e destacado nos objetivos dos pesquisadores.

No que diz respeito à relação teoria e prática, a partir do final da década de 1990, os resultados dessas pesquisas começam a apontar, com devida frequência, para a necessidade de se oportunizar essa aproximação. Destacando, inclusive, maneiras de se realizar tais integrações e levantando dificuldades de desenvolvimento dessas propostas, que deveriam acomodar em um mesmo projeto professores formadores de professores de Matemática/licenciandos em Matemática/professores atuantes na escola/alunos da escola/matemáticos. O que fica evidente com relação a essa categoria é que existem no Brasil (atualmente) diversos grupos buscando por essa integração, e para isso estruturam seus projetos e/ou propostas segundo diversos referenciais e/ou teorizações.

Foi possível, também, identificar outra categoria que denominamos por "um perfil para o licenciando". Nas primeiras reflexões ou pesquisas pode-se identificar a preocupação dos autores dos artigos em enfatizar a necessidade de este licenciando "saber" Matemática, e a graduação seria o momento em que essa Matemática deveria ser "ensinada" a ele. Posteriormente, questionou-se que esta Matemática "estudada" e "ensinada" na licenciatura precisaria estar relacionada à sua profissão como professor, ou seja, além de "saber" Matemática, ele deveria "saber como apresentar essa Matemática ao seu aluno da escola". É o momento em que o perfil do licenciando sofre alterações, isto é, precisa acomodar outras características, que não ser unicamente "um bom matemático", mas ser, também, "um bom professor de Matemática”. Desde então, é possível observar, pelo que apresentam os artigos, pesquisadores e colaboradores do campo de formação em busca de uma inter-relação e/ou integração entre teoria e prática e, por 
conseguinte, a constituição de um perfil de licenciando que dê conta das necessidades da escola e dos anseios que os formadores desses licenciandos possuem no que diz respeito ao "saber matemático".

O que se relata no parágrafo anterior mediante uma leitura paralela com a caracterização do que consideram como teoria e como prática e os projetos que buscam trazer clareza sobre as dicotomias pertinentes às confrontações geradas entre os que destacam cada uma delas isoladamente é que na área de Educação Matemática as propostas investigativas descritas nos artigos apontam para a superação dessa dicotomia entre a prática e a teoria.

Além do perfil do licenciando, evidenciou-se, dentre o que foi apresentado nos artigos, "um perfil para o formador". Não são muitos os autores que apresentam suas considerações sobre essa categoria construída, contudo, os dados revelam um movimento que sai de uma posição de "formador" para uma posição de "formador-pesquisador". Pelas reflexões apresentadas, compreende-se que o formador de professor, necessariamente, precisaria ser aquele que desenvolve pesquisas nessa área. Somente assim teria condições de compreender quais são as "verdadeiras" necessidades de seus graduandos em formação.

A presença de proposta ou projetos indicados como possíveis e que levam a resultados frutíferos é inúmera, no entanto, são proposições que envolvem uma quantidade pequena de professores em formação, e em suas considerações não temos informações que acenem para políticas públicas, temática esta - as políticas públicas - ausente nesses artigos pesquisados e que representam três décadas de produção da área de Educação Matemática no Brasil.

O desenvolvimento profissional dentro de uma política mais ampla, em que um planejamento contínuo, por diversos anos ou por uma década, seja apresentado, em momento algum foi abordado nos artigos analisados. Essa é uma das carências de pesquisa ou de reflexão naquilo que trazem os artigos da área de Educação Matemática publicados nesses periódicos no período considerado. Principalmente pelo fato de que ficou perceptível que há uma tendência em construção e em evidência nesta área apontando que a formação é um vir a ser, um desenvolvimento contínuo do professor.

Os dados mostram que um "novo" sentido parece estar se constituindo a respeito do professor e de sua formação - no qual o pensamento do professor (em formação inicial ou continuada) é considerado. 
O "novo" nesta tendência está relacionado ao fato de que os autores dos artigos já estão indicando essa necessidade de se aproximar do professor em seu ambiente de trabalho (observando-o em atuação), justificando-a inclusive com base nos resultados das pesquisas e ou intervenções realizadas, e, também, apontam que essa formação não está implicada (não se faz) somente nos momentos ou períodos formativos professorais, mas sua formação se processa continuamente, desde seus primeiros contatos com a escola e no seu dia a dia nesse ambiente em que age.

Com relação aos referenciais que ancoram essas propostas investigativas ou reflexivas, percebe-se que na década inicial, as citações ou menções aos referenciais estavam ausentes.

Na segunda década em análise, observa-se nitidamente um movimento em direção a indicar quais são os referenciais utilizados, e desse movimento conclui-se que as literaturas estrangeiras são as mais referenciadas.

A partir da terceira década, alguns dos autores começaram a citar resultados provenientes da literatura nacional, mesmo que de forma acanhada. Contudo, ao observarem-se os movimentos individuais para compor um movimento coletivo com relação a essa tendência - a presença de referências nacionais ou estrangeiras -, o que ainda se enxerga é o destaque às teorias provenientes do exterior.

Após a apresentação de alguns movimentos que se evidenciaram desta análise, indica-se a seguir algumas tendências (também perceptíveis mediante o estudo realizado): os projetos e/ou propostas apresentados nos artigos não se colocam abertamente como investigações do campo da formação de professores de Matemática, ou seja, são desenvolvidas atividades com os professores ou futuros professores, são coletadas diversas informações sobre o desenvolvimento dessas atividades, contudo não enfatizam a formulação das questões ou a indicação de objetivos que convirjam para a formação profissional do mestre mediante o que foi observado, coletado e analisado. Em diversos casos, há a identificação de regularidades, a descrição de propostas, o relato do desenvolvimento de projetos, o levantamento de percepções e crenças sem ficar perceptível para onde convergirão tais detecções e descrições, ou seja, que encaminhamentos posteriores são possíveis.

Outra tendência que se observa é a presença de pesquisas que propõem unicamente um contexto de promoção do desenvolvimento docente, sem se preocupar em pesquisar sobre este, ou seja, são aceitas pelos pesquisadores para seus ambientes de trabalho tanto situações que se limitam a realizar 
somente intervenções quanto as que utilizam os ambientes em "estado" de intervenção para a coleta de dados.

Contudo, esse movimento consolidado parece estar sofrendo ajustes quando visto juntamente com a tendência de se voltar para dentro da escola, ver o professor em ação, estudar e coletar os dados no dia a dia desse mestre. Porém, essa tendência do "retorno à escola", nos artigos, ainda só se apresenta como indicação. Quiçá seus resultados possam ser observados ao se analisar a próxima década de publicações - os anos posteriores a 2007, ano limitante de nossa construção.

Cabe também destacar neste momento que, mediante as ações investigativas indicadas no levantamento dos problemas ou objetivos de pesquisa, verifica-se que há uma diversidade muito grande de ações consideradas (pelos pesquisadores e/ou pessoas atuantes da comunidade de educadores matemáticos) como apropriadas para os contextos de formação. Por outro lado, pode-se pensar que há uma tendência forte para a dispersão. Entre essas ações (discutidas amplamente em Passos et al. 2007a) destacam-se: buscar significados, levantar percepções, situar e simular discussões, analisar, relatar, descrever, buscar a compreensão, apresentar resultados, apresentar análises, abordar percursos, fornecer guias, fornecer sugestões, discutir propostas, identificar regularidades, defender a importância, verificar relações, buscar explicações.

$\mathrm{Na}$ realidade, não se parte de algo determinado, definido a priori, para verificar os efeitos dos sentidos sobre o professor e sua formação apresentados nesses periódicos nas três décadas eleitas. Busca-se sistematizar por meio do que se encontra materializado nos artigos o que essa parcela de pesquisadores e colaboradores da área de Educação Matemática atingiu ao longo desses 32 anos de pesquisa (1976-2007). Isso nos conduz a algumas compreensões sobre o movimento dessa comunidade com relação ao campo da formação de professores.

\section{Considerações finais}

Nessas considerações finais, primeiramente, retoma-se a questão que deflagrou esta investigação: quais os sentidos de formação docente que estão subjacentes ou explícitos nos artigos publicados nesses periódicos? 
Para buscar uma compreensão do que se pretendia responder, algumas estratégias orientaram as ações dos pesquisadores - entre elas, a constituição do acervo; a seleção dos artigos; as leituras preliminares desses artigos; a opção em assumir que as palavras-chave encerram em si o significado global de um contexto; a constituição e definição de unidades de pesquisa e de análise.

Com relação aos "sentidos", as análises realizadas nesses artigos mostraram que a formação de professores é caracterizada por meio da definição de formação, de seus objetivos e funções; do que se espera do professor ao final do processo formativo; dos conteúdos matemáticos e/ou pedagógicos propostos; da proposição de atividades práticas; da sugestão de cursos e suas estruturas curriculares; da reflexão sobre seus limites e as possibilidades inerentes ao próprio campo.

Mediante o estudo sistematizado e próximo desses artigos, verificou-se que é possível encontrar subsídios, provenientes dessas problemáticas que já foram investigadas, que contribuam com a construção da identidade e dos saberes necessários aos professores (ou futuros professores) para a atuação em sua profissão; para o enfrentamento de desafios e problemas escolares que se apresentam, cotidianamente, nas salas de aula; para a conquista de autonomia do professorado com relação aos ajustes necessários no contexto escolar, em virtude das mudanças aceleradas que os acometem; para a construção de uma cultura profissional embasada em problemas surgidos no âmbito da prática (em contraponto ao exposto unicamente em argumentações teóricas); com a formação de novos professores, provenientes das licenciaturas que utilizam essas produções para recompor suas propostas de capacitação e habilitação; para manter um diálogo entre os formadores de professores que pertencem às universidades e os departamentos e secretarias municipais, estaduais e federais de educação responsáveis pela legislação, regulamentação e regulação dos princípios que dão norte ao ambiente educacional.

Foi também possível identificar que muito se pesquisa sobre o campo formação de professores no Brasil e que o movimento "nas" e "das" pesquisas mostra-se em paralelo ao que se desenvolve em âmbito internacional - considerando, inclusive, nossas especificidades e particularidades. E que a ênfase dada aos teóricos e referenciais estrangeiros é muito maior do que o destaque ao que é produzido e elaborado no País. 
O que fica "em aberto" após essas considerações apresentadas nos parágrafos anteriores - de maneira generalizada: novas questões podem ser levantadas; novas possibilidades se abrem para desenvolver outras investigações com esses periódicos acervados; há outras temáticas a serem identificadas; existem outros referenciais que podem ser utilizados como aporte de análise e de sistematização dos dados, ou seja, esta não é a única forma de abordagem e de desenvolvimento para esta pesquisa realizada com as revistas que constituem o acervo indicado.

Quanto aos critérios de seleção dos artigos utilizados, está-se ciente de que podem ter sido negligenciados ou deixados à margem alguns artigos, entretanto, acredita-se que os que foram selecionados contribuíram com a compreensão do que se buscava, mostrando um movimento da área com relação ao campo da formação de professores.

Finaliza-se este artigo destacando que uma pesquisa que se desenvolve sobre e sob periódicos jamais estará completa em função da atualização do acervo, das políticas, normas, regulações e regulamentações que os regem e os geram. Jamais estará completa ao se considerar que "um texto não fala", mas, sim, que é cada leitor que "o lê" segundo suas crenças, visões, possibilidades, ideias, teorias conhecidas, entre outras, produzindo assim efeitos de sentido nos leitores.

\section{Referências bibliográficas}

ANDRÉ, M. E. D. A. et al. Estado da arte da formação de professores do Brasil. Educação E Sociedade, ano XX, n.68, pp.301-309, dezembro/1999.

ANDRÉ, M. E. D. A. (Org.). Formação de professores do Brasil (1990-1998). Brasília - DF: MEC/Inep/Comped, 2002. 364p.

BARDIN, L. Análise de conteúdo. Lisboa: Edições 70, 1977, 3. ed., 2004. 223p.

FERREIRA, A. C. Um olhar retrospectivo sobre a pesquisa brasileira em formação de professores de matemática. In: FIORENTINI, D. (Org.). Formação de professores de matemática: explorando novos caminhos com outros olhares. Campinas: Mercado de Letras, pp.19-50, 2003.

FIORENTINI, D. et al. Formação de professores que ensinam matemática: um balanço de 25 anos da pesquisa brasileira. Educação em Revista, Faculdade de Educação da Universidade Federal de Minas Gerias - UFMG, n.36. Belo Horizonte, pp.137-160, dez. 2002. 
MELO, M. V. Três décadas de pesquisa em Educação Matemática: um estudo histórico a partir de teses e dissertações. Dissertação (Mestrado) - Universidade Estadual de Campinas, Faculdade de Educação. Campinas, 2006. 288p.

MORAES, R. Análise de conteúdo. Educação, Porto Alegre: Pontifícia Universidade Católica do Rio Grande do Sul, ano XXII, n.37, pp.7-31, março 1999.

NAVARRO, P.; DÍAZ, C. Análisis de contenido. In: DELGADO, Juan Manuel; GUTIÉRREZ, Juan. (Coords.) Métodos y técnicas cualitativas de investigación en ciencias sociales. Madrid: Síntesis, 1999. 669p.

PASSOS, M. M.; NARDI, R.; ARRUDA, S. M. Análises preliminares de revistas da área de Educação Matemática. In: V ENPEC - ENCONTRO NACIONAL DE PESQUISA EM EDUCAÇÃO EM CIÊNCIAS, 5, 2005, Bauru. Anais... Bauru, 12p. 2005. CD- ROM.

PASSOS, M. M.; NARDI, R.; ARRUDA, S. M.. Primeiras análises de revistas da área de Educação Matemática: a formação do professor em foco. In: SEMINÁRIO INTERNACIONAL DE PESQUISAS EM EDUCAÇÃO MATEMÁTICA - SIPEM, 3, 2006, Águas de Lindoia. Anais... Águas de Lindoia, 2006.

PASSOS, M. M.; NARDI, R.; ARRUDA, S. M. 1996 - 2005: o que foi pesquisado sobre formação de professores? A busca por respostas em revistas da área de Educação Matemática. In: CONGRESSO INTERNACIONAL DE ENSINO DA MATEMÁTICA - CIEM, 4, 2007, Canoas. Anais... Canoas, 8p, 2007a.

PASSOS, M. M.; NARDI, R.; ARRUDA, S. M. A pesquisa sobre a formação inicial de professores no Brasil em revistas da área de Educação Matemática. In: ENCONTRO NACIONAL DE PESQUISA EM ENSINO DE CIÊNCIAS, 6, 2007, Florianópolis. Anais... Florianópolis, 2007b. 12p.

PASSOS, M. M.; NARDI, R.; ARRUDA, S. M. O campo formação de professores em revistas brasileiras da área de educação matemática. Revista Educação Matemática Pesquisa, São Paulo: Pontifícia Universidade Católica - PUC, v.10, n.1, 2008. 41p.

PASSOS, M. M.; NARDI, R.; ARRUDA, S. M. As concepções sobre o professor em 32 anos de Boletim Gepem: 1976/2007. Boletim Gepem, Rio de Janeiro: Instituto de Educação da UFRuralRJ, n.54, jan./jun. 2009. 26p. 



\title{
13 \\ FormaÇÃo de PROFESSORES DE CIÊNCIAS EM EXERCÍCIO NO ESTADO DA BAHIA
}

\author{
Daisi Teresinha Chapani ${ }^{1}$ \\ Lizete Maria Orquiza de Carvalho ${ }^{2}$
}

\section{Introdução}

As políticas públicas têm se constituído um foco de menor interesse nos estudos sobre formação docente (André, 2002), particularmente naqueles que se relacionam aos professores de Ciências e Biologia (Megid Neto, 2006), daí a nossa preocupação em aprofundarmos essa questão.

Para Vieira (2002), a formação de professores, como política pública, deve ser entendida como parte da política educacional, que como as demais, embora envolva um amplo conjunto de agentes, expressa-se, "sobretudo, por meio de iniciativas direta ou indiretamente promovidas pelo poder público e, portanto, o Estado é uma referência fundamental para a sua compreensão" (p.14). Concebemos o Estado como uma arena na qual se confrontam sujeitos com interesses divergentes e com diferentes possibilidades de exercício do poder.

Consideramos que as políticas públicas de formação devem ser estudadas em seu conjunto, que compreende uma dimensão estrutural relativa às ações destinadas ao estabelecimento dos espaços de formação no interior da qual se desenvolve um currículo. Embora de natureza diversa, essas duas facetas estão intimamente relacionadas, no entanto, neste trabalho, daremos

1 UESB - Universidade Estadual do Sudoeste da Bahia -Jequié/BA. Departamento de Ciências Biológicas. Doutoranda do Programa de Pós-Graduação em Educação para a Ciência - Unesp/Bauru. E-mail:dt.chaponi@bol.com.br.

2 Unesp - Universidade Estadual Paulista - Faculdade de Engenharia de Ilha Solteira/campus de Ilha Solteira. Docente do Departamento do Física e Química e do Programa de Pós-Graduação em Educação para a Ciência-Unesp/Bauru. E-mail: lizete@dfq.feis.unesp.br. 
mais ênfase ao primeiro aspecto, inclusive porque discussões a respeito da dimensão curricular dessas políticas contam já com alguns estudos (Dias; Lopes, 2003; Lopes, 2004, 2005; Silva; Lopes, 2007).

A partir dessas considerações, nos propomos a construir um quadro que contribua para clarear as condições de formação de professores de Ciências em exercício na Bahia, mais especificamente no município de Jequié, nas últimas três décadas. Defendemos que o conhecimento das diversas realidades nas quais se concretizam as políticas de formação, muitas vezes elaboradas tendo em vista âmbitos mais ampliados, pode trazer contribuições interessantes para as discussões sobre o processo de recontextualização dessas políticas. Nosso interesse por essa região geográfica justifica-se pela ausência de estudos acadêmicos ali desenvolvidos relativos ao assunto, bem como pelo fato de a primeira autora desse trabalho atuar como formadora de professores naquele município.

\section{Procedimentos}

Pedimos a 16 professores de Ciências que nos contassem a história de sua formação. Eles eram homens e mulheres, licenciados em Ciências Biológicas, que lecionavam em instituições públicas e privadas, de nível básico e superior, com idade entre 26 e 51 anos e tempo de magistério entre 1 e 30 anos.

Depois de transcrevermos as entrevistas, buscamos entrelaçar as histórias dos docentes com as políticas de formação fazendo uso da legislação pertinente, documentos, estudos acadêmicos e fontes bibliográficas diversas. Aqui apresentamos uma versão resumida dos resultados obtidos nesse esforço, restringindo nossas reflexões sobre três tópicos que consideramos mais estreitamente relacionados com as particularidades da região: i) docência leiga, ii) formação inicial em serviço e iii) formação continuada.

\section{A formação de professores em exercício na Bahia nas últimas décadas}

A formação em exercício tem assumido diversos papéis, definidos muitas vezes a partir de pressupostos díspares, como: habilitar leigos, corrigir 
deficiências da formação inicial, introduzir inovações curriculares, promover a atualização dos docentes, provocar mudanças epistemológicas, favorecer o aprimoramento profissional, promover reflexões sobre a prática, estabelecer elos entre a pesquisa educacional e a escola etc. De consenso temos o apelo à sua importância, o reconhecimento de sua complexidade e do papel central ocupado pela prática pedagógica nesse contexto (André, 2002; Chapani, 2008; Freitas e Villani, 2002).

Ela é definida como um direito do professor, e os sistemas de ensino têm estabelecido normas visando à participação dos docentes em variadas ações desta natureza, mas nos importa conhecer como essas ações efetivamente têm se concretizado na Bahia.

\section{Contexto}

Antes de adentramos nas discussões dos tópicos de interesse deste trabalho, é necessário delinearmos um quadro um pouco mais amplo das políticas de formação abrangendo tanto a dimensão curricular quanto a estrutural.

\section{Ênfase na dimensão curricular}

No contexto das ações estatais sobre a dimensão curricular das políticas de formação, ganham relevo a lei 9.394/1996 (LDB) e as Diretrizes Curriculares Nacionais para a Formação de Professores da Educação Básica (Diretrizes).

$\mathrm{Na} \mathrm{LDB}$, com relação à formação docente, destacam-se, além dos direitos já explicitados na Constituição, a determinação para que os processos formativos ocorram com estreita associação entre teoria e prática, a exigência de formação em nível superior para o exercício da docência nas séries mais adiantadas da educação básica e a consideração da experiência docente como pré-requisito para o exercício profissional. Essas determinações há tempos constam das agendas dos movimentos dos educadores e das discussões acadêmicas, outras, no entanto, vão na contramão das lutas históricas em favor da valorização e profissionalização docentes, como é o caso da criação de espaços de formação inicial desvinculados das universidades (Brzezinski, 2005; Diniz-Pereira, 1999; Freitas, 1999, 2002).

Embora a intervenção estatal no currículo não seja exatamente uma novidade, tem havido uma intensificação nesse processo (Dias; Lopes, 2003). 
Nesse contexto, as Diretrizes, assentadas nos pressupostos de flexibilização e competência, enlaçam a formação docente às necessidades atuais do capitalismo e ao mesmo tempo permitem um fino controle governamental sobre essa formação por meio de processos de avaliação e certificação.

Diversos estudiosos (Brzezinski, 2005; Diniz-Pereira, 1999; Freitas, 1999, 2002; Melo, 1999) têm denunciado o caráter técnico-instrumental e as possibilidades de fragmentação e aligeiramento contidos nas atuais políticas de formação, questionando também sua fundamentação epistemológica, que estaria sendo utilizada para justificar o atrelamento das políticas de formação ao poder econômico.

\section{Ênfase na construção de uma estrutura para formação docente}

Os movimentos verificados no governo do estado da Bahia desde os anos 1980 seguem o padrão de substituição de políticas mais assentes em preocupações sociais para aquelas fundamentadas em princípios neoliberais. Já no começo da década de 1990, iniciou-se a reformulação administrativa da Bahia, objetivando, sob certos aspectos, seu enquadramento nos moldes de uma economia globalizada, coadunando-a com a reforma do Estado que já se fazia presente em âmbito federal. Como sempre, a educação foi proclamada como prioritária entre as políticas sociais e considerada fundamental para o desenvolvimento econômico do Estado. Diversas ações foram levadas a cabo, inclusive, com relação à formação docente, a centralização das ações desta natureza no Instituto Anísio Teixeira (IAT). Ligado à Secretaria Estadual de Educação (SEC), o IAT é responsável, entre outras coisas, pela concepção e realização de cursos de formação inicial e continuada, configurando-se como executor das políticas de formação docente na Bahia, especialmente dos professores em serviço da rede estadual (Bahia, 2009; Nascimento, 1999; Silva, 2007).

Desde meados dos anos 1990 a política macroeconômica brasileira tem sofrido forte influência do Banco Mundial (BM), com consequências no campo educacional, visto que os empréstimos concedidos por essa instituição estão atrelados à submissão às suas orientações na elaboração e execução de projetos. Muitas ações desenvolvidas pelo Estado da Bahia para formação dos professores da rede pública contaram, além dos recursos estaduais, com financiamento federal e de agências internacionais (Machado, 2001; Silva, 2007; Tommasi, Warde, Haddad, 2000). 
A partir de 1999, o governo da Bahia iniciou uma reforma educacional que foi intitulada de "Programa Educar para Vencer", que agregava projetos prioritários para fortalecer a escola com o foco na qualidade do Ensino Básico da rede pública. Para o seu desenvolvimento, foram estabelecidas estratégias de gestão com a participação de instituições diversas, como a Fundação Luiz Eduardo Magalhães, as universidades públicas e prefeituras municipais. O programa foi financiado pelo Projeto Bahia, que por sua vez, recebeu recursos provenientes de empréstimos do BM com contrapartida do governo estadual.

Portanto, é no contexto das reformas educativas, que envolvem uma série de ações governamentais em diversos níveis, mas também são sujeitas a críticas e resistências e das quais participam diferentes atores, que analisaremos mais detidamente a formação de professores em exercício na Bahia, incluindo daqueles que atuam sem possuir a habilitação mínima exigida.

\section{A docência leiga}

O aviltamento salarial e as más condições de trabalho desestimulam jovens a optarem pela carreira docente. Esses fatos, aliados à incapacidade de formação de profissionais de educação em número suficiente para atendimento da demanda, fazem com que se acumulem aos demais problemas educacionais brasileiros a falta pura e simples de docentes com formação mínima para o exercício da profissão.

Na Bahia, especialmente no interior, esse sempre foi um grave problema (Besnosik, 1993; Teixeira, 2001), que, em algumas localidades, persiste até os dias de hoje (Bahia, 2008a). Nani, uma professora por nós entrevistada, exemplifica bem a situação dos professores leigos desta região em um passado nem tão remoto, pois ingressou no magistério quando tinha apenas completado a $6^{a}$ série. Diversos outros entrevistados começaram ensinar Ciências sem que tivessem formação específica para isso e, nessa condição, também podem ser considerados leigos. Eles relataram os inúmeros obstáculos que tiveram que superar, sendo que o mais sentido foi com relação ao ensino dos conteúdos de Química e Física. O depoimento de Cori é um exemplo:

É porque eu não sabia nada. Eu ensinei uma $7^{\mathfrak{a}}$ e $8^{a}$, porque era obrigada. Eu chorava: "não quero". Hoje, graças a Deus, passou esse pavor, porque eu tinha 
um medo de Química e Física! Mas venci, aprendi Ciências dessa maneira, foi assim, dessa maneira, pegando e estudando (Cori).

Em termos de políticas públicas, diversas ações vêm sendo desenvolvidas para a habilitação desses docentes, as quais são, via de regra, desvinculadas de uma política geral de valorização profissional, fazendo com que permaneçam as condições que levaram a essa situação. Os entrevistados contaram como, sozinhos, buscaram meios de superar os embaraços que enfrentavam:

Uma dificuldade que eu tive, quando fui ensinar 8 a série, foi aquela parte de Química. Eu questionava a colega que sabia mais do que eu, tentava aprender pra no outro dia dar aula, e sempre que ia dar uma aula, eu buscava o livro (Nani).

Embora seja louvável a atitude dos professores de procurarem por si mesmos suprir suas deficiências formativas, tais ações evidenciam uma política voltada para a improvisação e o imediatismo que atribui aos docentes a responsabilidade de resolver sérios problemas educacionais, como a falta de professores adequadamente formados.

Embora o curso secundário de magistério tenha o objetivo de formar docentes para as séries iniciais do Ensino Fundamental, para diversos de nossos entrevistados, subsidiou também suas atuações em Ciências e Biologia nas séries mais avançadas do Ensino Fundamental e no Ensino Médio. Alguns consideraram que o curso lhes deu condições de exercer sua função como professor de Ciências, porém, o fato de ser muitas vezes considerado um curso fraco dificultou o prosseguimento de estudos, colaborando para a permanência na profissão daqueles que se consideravam menos qualificados:

[O curso de magistério] deu base pra querer a matéria Ciências, mas não base pro vestibular, por isso eu nunca consegui passar no vestibular. Era muito concorrido na época, e eu não tinha formação, só magistério não dava preparação nenhuma. Fiz vários vestibulares, mas nunca passei (Auri).

Eles também indicaram que a maneira deficiente com que os conteúdos específicos foram tratados no curso do magistério dificultou sua formação na licenciatura. 
A minha licenciatura deixou a desejar porque eu tive que trabalhar durante o dia no comércio. Eu não tinha como estudar, então eu já fiz um curso assim... meio que capengando. Eu vim de um curso de magistério que não tinha conhecimento de Matemática, de Química, de Física, tive muita dificuldade nisso. Tranquei uma disciplina de Química porque não estava tendo como acompanhar (Jeri).

Essas particularidades têm consequências para a formação, especialmente no que se refere à consolidação de um determinado tipo de prática que precisaria ser tematizada nos processos formativos posteriores (Chapani, 2008). Além disso, as dificuldades apontadas trazem implicações para a educação básica que, no âmbito deste trabalho, só é possível resvalar: que tipo de ensino desenvolve um professor que tem pavor de dado conteúdo, que não consegue aprender adequadamente um conteúdo básico da disciplina na qual atua devido à sua formação anterior precária ou que não pode se dedicar a sua formação por falta de tempo?

\section{A formação inicial em exercício}

A determinação de formação em nível superior para professores de educação básica e as diferentes possibilidades de formação e de complementação pedagógica para bacharéis deram origem a uma série de programas formativos em exercício, proporcionados também pelas recomendações e financiamentos de organismos internacionais, pelos incentivos do MEC e pelas facilidades trazidas pelas novas tecnologias de informação e comunicação. Tais programas tiveram como principais justificativas a melhoria da educação básica e a valorização do professor pela promoção de sua profissionalização.

O Estado da Bahia é um dos possui maior número de professores sem qualificação mínima exigida pela legislação. Em 2004, havia mais de 66.000 professores lecionando nas séries finais do Ensino Fundamental, dos quais aproximadamente $36 \%$ apresentavam curso de licenciatura completo. No Ensino Médio, dos 30.105 docentes, pouco mais de $60 \%$ possuíam essa formação (Bahia, 2008a).

Diante desta realidade, o Governo do Estado da Bahia vem implementando políticas que visam atender às novas exigências de qualificação para o trabalho 
docente no Brasil e no mundo. Todas elas bem ajustadas às novas exigências de formação/qualificação de um trabalhador de novo tipo, necessário ao novo modelo de reestruturação do capital. Nesta tarefa, tais políticas têm se voltado à formação de profissionais, pautados no discurso de competência, conceito muito utilizado na contemporaneidade e que busca atender aos princípios da flexibilidade, autonomia e criatividade, para citar alguns requisitos (Macedo, 2006, p.3).

Assim, o IAT constituiu três programas de formação "inicial" para professores em exercício da rede estadual: modalidade presencial, destinado a dar licenciatura plena para aqueles que atuavam nas últimas séries do Ensino Fundamental e no Ensino Médio; modalidade a distância, que visava oferecer complementação pedagógica a fim de licenciar bacharéis; e Próformação, para oferecimento de curso normal em serviço para professores das primeiras séries do Ensino Fundamental.

A formação de professores em serviço na sua modalidade presencial foi regulamentado pelo Decreto 8.523/2003, e sua efetivação ocorreu por meio de convênios celebrados entre a SEC e as universidades públicas para o oferecimento de cursos de graduação plena aos professores do quadro efetivo da rede estadual que possuíam nível médio ou licenciatura curta (Bahia, 2008b). Um desses cursos, frequentado por quatro de nossos entrevistados, foi realizado com aulas presenciais em uma universidade pública, com duração de três anos. Esses professores já haviam tentado realizar um curso superior e valorizaram muito a possibilidade de participar desse projeto especial, apesar de apresentarem alguns senões, particularmente relativos à falta de tempo para dedicar-se aos estudos.

Havia o temor que cursos criados especialmente para habilitação de docentes em serviço pudessem se constituir em processos frágeis e aligeirados, estabelecendo-se apenas como um procedimento de diplomação (Brzezinski, 2005; Diniz-Pereira, 1999; Freitas, 2002). Ao analisar o curso referido acima, Chapani (2008) notou que algumas situações antecipadas por esses estudiosos com relação à qualidade da formação realmente se efetivaram, mas, por outro lado, a participação no curso promoveu algumas mudanças nas práticas dos docentes.

Outro projeto do governo estadual envolveu uma parceria do IAT com a Universidade Federal de Santa Catarina (UFSC) visando implementar um programa de educação a distância, no âmbito do qual várias ações foram 
desenvolvidas, destacando-se o mestrado em Mídia e Conhecimento e o Curso de Complementação para Licenciatura em Física, Química, Biologia e Matemática envolvendo aproximadamente 1.400 professores da rede pública estadual, bacharéis em diversas áreas (Ribeiro, 2002).

\section{A formação continuada}

Relativo à formação continuada, gratificações e incentivos de cunho pessoal têm sido explicitados na legislação sobre o assunto, como parte da difusão do pensamento de que esses artifícios possam estimular respostas autointeressadas (Ball, 2006), de tal maneira que se tenha um corpo de profissionais mais bem qualificado. O Estatuto do Magistério da Bahia (Lei 8.261/2002) valoriza esse tipo de ação formativa por meio da "Gratificação de Estímulo ao Aperfeiçoamento Profissional”, que possibilita a vantagem de $5 \%$ a $25 \%$ do salário do docente que concluir cursos de "atualização, aperfeiçoamento ou pós-graduação”. Também determina que sejam considerados de efetivo exercício os afastamentos para: "aperfeiçoamento, especialização ou atualização"; comparecimento a "reuniões ou congressos relacionados com a atividade docente que lhe seja pertinente", muito embora, segundo nossos entrevistados, esse artigo não seja automaticamente cumprido.

Os docentes valorizaram bastante as ações formativas dessa natureza e fizeram menção a diversos cursos, especialmente os oferecidos pelas redes de ensino e por uma universidade pública da região. Além da progressão na carreira, eles indicaram como fator de motivação para o envolvimento nessas ações principalmente a necessidade de superar as deficiências relativas à formação anterior, a imprescindível atualização e a aprendizagem de conteúdos e procedimentos que fossem úteis em sala de aula.

Eles se referiram também a entraves que impediram ou dificultaram seu envolvimento em ações desse tipo, principalmente o pequeno oferecimento ou divulgação precária dos cursos e os embaraços para afastamento das aulas a fim de frequentá-los. Um dos obstáculos mais citados estava relacionado com a seleção dos professores para participação nos cursos. Alguns explicitaram situações constrangedoras em que se desentenderam com colegas e dirigentes ou usaram de subterfúgios para atingir esse objetivo, como exemplificado no trecho do depoimento de Mari: 
Teve um em Salvador voltado pra Ciências, só com experimentos usando material de sucata. Eu fui fazer esse curso porque uma ex-diretora da escola esteve na Direc e viu esse curso, e quando ela viu se lembrou de mim. Eu fiz a inscrição e fui. Os cursos que têm no IAT são cursos bons, mas quando chega à Direc, têm as pessoas privilegiadas, aí acaba mandando alguém que gosta muito de ir, às vezes, nem pelo curso, porque vai pra Salvador, vai ficar em hotel, entendeu? Infelizmente é isso que acontece (Mari).

As situações descritas pelos entrevistados deixam claro que a participação dos professores em cursos para a sua formação nem sempre é vista como um direito, mas como um privilégio pessoal, de maneira que cabe aos gestores, especialmente aos diretores de escola, a distribuição dessa regalia. No entanto, a luta dos docentes dentro da escola para participar desses cursos às vezes resulta vitoriosa, como descrito por Alma:

A direção procura fazer uns horários pra facilitar. Isso depois de muita discussão, porque na minha época nem era assim, ao contrário, muitas vezes eu tive que desistir de determinada disciplina porque tava chocando, entendeu? Agora, hoje não, isso aí já é uma coisa que a gente conseguiu (Alma).

Muito embora as redes públicas apresentem formação continuada em termos de cursos com cargas horárias variadas, a prioridade em habilitar os professores, especialmente no caso da rede municipal, fez com que essas atividades fossem um tanto secundarizadas, inclusive porque os professores ficaram sem tempo para envolver-se em outras ações formativas, uma vez que mantiveram sua carga de trabalho com o acréscimo da graduação (Bispo, 2008). Espera-se que a participação dos docentes nesse tipo de atividade venha a aumentar, uma vez que todos tenham concluído a licenciatura.

Apesar do oferecimento de cursos diversos, alguns professores alegaram que não tiveram oportunidades de participar de ações formativas para situações de ensino específicas, como para educação de jovens e adultos e educação no campo.

Para Medeiros (2005 p.203), "a formação inicial articulada à formação continuada, em nível de pós-graduação, preferencialmente stricto sensu, constitui-se em um investimento social indispensável à profissionalização docente". No entanto, quando a luta ainda é para que todos os docentes sejam formados em nível superior e perante todas as dificuldades apontadas pelos entrevistados para cumprir esse requisito mínimo e dar sequência à sua formação acadêmica, verifica-se o quão longe estamos desse ideal. 
Apesar disso, os entrevistados nos deram indicações de que têm interesse por esse tipo de formação, e que, havendo condições mínimas para sua realização, eles as aproveitam, como no caso dos diversos cursos de pós-graduação lato sensu oferecidos por instituições públicas e privadas da região e frequentados por eles. Por outro lado, pós-graduação stricto sensu é uma meta distante para os professores da educação básica. A Bahia apresentava em 2008 apenas três programas desse tipo relacionados à educação, todos em Salvador (Brasil, 2009).

Os docentes também participam de momentos de formação contínua na própria escola, proporcionados principalmente pelas horas de Atividades Complementares (AC) e pela Semana Pedagógica. De acordo com o Estatuto do Magistério, as AC correspondem a 27\% da carga horária do professor e destinam-se à preparação e avaliação do trabalho didático, às reuniões pedagógicas e ao aperfeiçoamento profissional, sendo atribuição dos coordenadores pedagógicos, entre outras, coordenar e acompanhar essas atividades, viabilizando a atualização pedagógica em serviço. Para os entrevistados, no entanto, esses espaços nem sempre apresentam um caráter formativo:

Lá na escola, o pessoal às vezes dizia isso: que faltava, na reunião, o pessoal falar o que estava acontecendo, e juntar, e fazer as coisas, os projetos. Só que o pessoal lá ficava muito preocupado em dar a sua aula, de fazer seu papel lá na escola, e quando chegavam os momentos de AC, em vez de discutir alguma coisa da escola, ficava ali preparando seu exercício, sua prova e tal e conversando a respeito de outros assuntos (Davi).

Tinha aquela questão da semana pedagógica que discutia muito sobre educação, sobre os projetos a serem desenvolvidos, mas que na realidade só ficava na teoria. Na prática, era cada professor por si só (Sílvia).

As alusões negativas a esses momentos referiram-se ao fato de eles, em geral, serem mal organizados, tratarem de questões que os docentes não consideravam relevantes e sem conexão com sua prática. Com relação aos aspectos positivos, citaram a oportunidade de trocas de experiências, de receber orientações dos coordenadores e de preparar suas aulas.

A partir de uma perspectiva crítica, entendemos formação como um processo de tomada de posição com relação à cultura e às normas sociais por parte dos professores ou dos futuros professores. A que se constitui 
em serviço, particularmente na própria escola, por ocorrer em situação de maior simetria entre os participantes e no próprio local de trabalho, poderia levar a discussões sobre questões prementes desse contexto, o que, se realizado de maneira participativa, possibilitaria "a valorização e a avaliação crítica das precompreensões da prática pedagógica concreta dos docentes" (Mühl, 1999, p.257), criando condições para um processo educativo inovador.

Por isso consideramos preocupante que os momentos de trabalho coletivo nas escolas, tão duramente conquistados pela classe docente, nem sempre sejam reconhecidos como espaços de formação. Consideramos que temos aqui um caso exemplar das elaborações de Apple (1989), para quem as pessoas em seu trabalho não se submetem passivamente às formas de controle, no entanto, nem sempre as resistências impostas pelos trabalhadores modificam as exigências do poder hegemônico.

\section{Considerações finais}

A formação de professores de Ciências em exercício no Estado da Bahia tem se dado de maneira bastante diversificada, envolvendo instituições públicas e privadas, em programas presenciais e a distância, de caráter "inicial” ou em continuidade, custeados pelo poder público ou pelos próprios docentes, como parte da carga horária de trabalho ou fora dela, constituindo-se desde cursos de alguns dias até programas de licenciatura e pós-graduação. A despeito da quantidade e da variedade de propostas formativas, há muito que ser feito para que a formação em serviço venha se constituir de fato em um direito do professor.

As condições socioeconômicas em que se inserem, bem como a tradição, a cultura local e aspectos gerais da organização escolar, efetivamente atuam no processo de implementação das políticas de formação, que, em certos aspectos, acabam por concretizar-se de maneira distinta daquela que foram definidas. Essas divergências nem sempre se constituem como um processo de resistência, mas mera desconsideração pelos procedimentos. Talvez esteja justamente aqui uma possibilidade para aqueles que lutam por uma educação transformadora: a politização dos espaços de formação em serviço como resposta contra-hegemônica. 


\section{Referências bibliográficas}

ANDRÉ, M. (Org.). Formação de professores no Brasil (1990-1998). Brasília: MEC/Inep/Comped, 2002.

APPLE, M. W. Educação e poder. Porto Alegre: Artes Médicas, 1989.

BAHIA. Assembleia Legislativa. Lei 8.261 de 29 de maio de 2002. Dispõe sobre o Estatuto do Magistério Público do Ensino Fundamental e Médio do Estado da Bahia e dá outras providências.

. Secretaria da Educação do Estado da Bahia. Estatísticas. Disponível em: <www.sec.ba.gov.br/estatística/indicadores.htm> Acesso em: 20 jun. 2008a. Secretaria da Educação do Estado da Bahia. Programas e Projetos. Formação para Professores. Disponível em: <http://www.sec.ba.gov.br/>. Acesso em: 7 nov. 2008b.

Secretaria da Educação do Estado da Bahia. Instituto Anísio Teixeira. Portifólio. Disponível em: <http://www.sec.ba.gov.br/iat/> Acesso em: 20 abr. 2009.

BALL, S. Sociologia das políticas educacionais e pesquisa crítico-social. Currículo sem Fronteiras. v.6, n.2, pp.10-32, jul/dez 2006. Disponível em: <http://www. curriculosemfronteiras.org >. Acesso em: 26 dez. 2008.

BESNOSIK, M. H. R. O professor leigo e sua participação política na zona rural da Bahia: um estudo de caso. Dissertação (Mestrado). Universidade Federal da Bahia. Faculdade de Educação. Salvador: UFBA, 1993.

BISPO, M. G. Entrevista concedida por Maria das Graças Bispo, Secretária de educação do município de Jequié, à Daisi Teresinha Chapani em 26 jun. 2008. Arquivo pessoal.

BRASIL. Congresso Nacional. Lei 9.394 de 20 de dezembro de 1996. Estabelece as diretrizes e bases da educação nacional.

. Coordenação de Aperfeiçoamento de Pessoal de Nível Superior (CAPES). Relação de cursos recomendados e reconhecidos. Disponível em: <http://conteudoweb.capes.gov.br/conteudoweb/ProjetoRelacaoCursosServlet?acao=pesqu isarGrandeArea> Acesso em: 19 maio 2009.

BRZEZINSKI, I. A formação e a carreira de profissionais da educação na LDB 9.394/96: possibilidades e perplexidades. In: BRZEZINSKI, I. (Org.). LDB interpretada: diversos olhares se entrecruzam. 9.ed. São Paulo: Cortez, pp.147168, 2005.

CHAPANI, D. T. Formação acadêmica em serviço: avanços, resistências e contradições de um grupo de professores de ciências. Ensaio, v.10, n.1, jun. 2008. Disponível em: <http://www.fae.ufmg.br/ensaio/volume10_n1.htm>. Acesso em: 07 out. 2009.

DIAS, R. E.; LOPES, A. C. Competências na formação de professores no Brasil: o que (não) há de novo. Educação e Sociedade, v.24, n.85, pp.1155-1177, dez. 2003. 
DINIZ-PEREIRA. J. E. As licenciaturas e as novas políticas educacionais para a formação docente. Educação e Sociedade, ano XX, n.68, pp.109-125. dez. 1999. FREITAS, D.; VILLANI, A. Formação de professores de ciências: um desafio sem limites. Investigações Ensino de Ciências. v.7, n.3, dez. 2002. Disponível em:<http://www.if.ufrgs.br/public/ensino/revista.htm> Acesso em: 20 jun. 2004.

FREITAS, H. C. L. A reforma do ensino superior no campo da formação dos profissionais da educação básica: as políticas educacionais e o movimento dos educadores. Educação e Sociedade, ano XX, n.68, pp.17-44, dez. 1999.

Formação de professores no Brasil: 10 anos de embate entre projetos de formação. Educação e Sociedade, v.23, n.80, pp.136-167, setembro de 2002.

LOPES, A. C. Políticas de currículo: mediação por grupos disciplinares de ensino de ciências e matemática. In: LOPES, A.C.; MACEDO. E. (Org.). Currículo de ciências em debate. Campinas: Papirus, 2004. (p.45-76).

Política de currículo: recontextualização e hibridismo. Currículo sem Fronteiras, v.5, n.2, pp.50-64, jul./dez 2005. Disponível em: <www.curriculos emfronteiras.org >. Acesso em: $26 \mathrm{dez} .2008$.

MACEDO, J. M. Políticas de formação/qualificação de professores em exercício no estado da Bahia. In: VI SEMINÁRIO DA REDESTRADO: Regulação educacional e trabalho docente. Atas...Universidade Estadual do Rio de Janeiro: Rio de Janeiro: UERJ, 2006.

MACHADO, C. T. O Projeto Nordeste e a formação do professor: diretrizes da reforma educacional brasileira. Dissertação (Mestrado). Pontifícia Universidade Católica de São Paulo. Programa de Pós-graduação: Educação, História, Política e Sociedade. São Paulo: PUCSP, 2001.

MEDEIROS, A. M. S. Formação de professores sob a perspectiva da teoria crítica e das políticas educacionais. Educação e Linguagem, ano 8, n.11, pp.195-210, jan./jun. 2005.

MELO, M. T. L. Programas oficiais para formação dos professores da educação básica. Educação e Sociedade, ano XX, n.68, pp.45- 60, dez. 1999.

MEGID NETO, J. Três décadas de pesquisas em educação em ciências: tendências de teses e dissertações. In: NARDI, Roberto (Org). A pesquisa em ensino de ciências no Brasil: alguns recortes. São Paulo: Escrituras, 2007.

MÜHL, E. H. Racionalidade comunicativa e educação emancipadora. Tese (Doutorado). Universidade Estadual de Campinas. Faculdade de Educação. Campinas: Unicamp, 1999.

NASCIMENTO, G. C. Cursos de aperfeiçoamento profissional: limites e possibilidades para a prática docente. Dissertação (Mestrado). Universidade Federal da Bahia. Faculdade de Educação. Salvador: UFBA, 1999.

RIBEIRO, S. F. A formação de professores em exercício através da educação a distância: perspectivas da Universidade do Estado da Bahia. Dissertação (Mestrado). Universidade Federal de Santa Catarina. Florianópolis: UFSC, 2002. 
SILVA, A. A. Políticas públicas para educação básica na Bahia nos anos 90: propostas de ações nas gestões de Antonio Carlos Magalhães e Paulo Souto (19911998). Tese (Doutorado). Universidade de São Paulo. Faculdade de Educação. São Paulo: USP, 2007.

SILVA, D. B. R.; LOPES, A. R. C. Competências nas políticas de currículo: recontextualização pela comunidade disciplinar de ensino de física, Revista Brasileira de Pesquisa em Educação em Ciências, v.7, n.1, 2007. Disponível em: <http:// www.fae.ufmg.br/abrapec/revista/index.html> Acesso em: 20 abr. 2009.

TEIXEIRA, A. O ensino no estado da Bahia. Relatório apresentado ao governador do estado da Bahia, por intermédio do Secretário do Interior, Justiça e Instrução Pública, pelo Diretor Geral de Instrução. Salvador: Gráfica do Colégio Apoio, 2001 (ediçãofac-simile).

TOMMASI, L.; WARDE, M. J.; HADDAD, S. (Orgs.). O Banco Mundial e as políticas educacionais. 3. ed. São Paulo: Cortez, 2000.

VIEIRA, S. L. Políticas de formação em cenários de reforma. In: VEIGA, I. P. A.; AMARAL, A. L. (Orgs). Formação de professores: políticas e debates. Campinas: Papirus, pp.13-45, 2002. 



\section{4 \\ Ensino de Ciências Naturais e a formação DE PROFESSORES: POTENCIALIDADES DO ENSINO NÃO FORMAL DA ASTRONOMIA}

Rodolfo Langhi ${ }^{1}$

Roberto Nardi ${ }^{2}$

\section{Introdução}

O interesse por temas sobre Astronomia, eventualmente, tem sido despertado, principalmente quando ocorrem fenômenos astronômicos ou descobertas sobre o cosmo que interessam à divulgação midiática. Porém, ainda se preserva, no íntimo humano, o desejo e a necessidade de ampliar seus limites do saber, abrangendo lugares tão distantes quanto os limites do cosmo. Neste sentido, os locais que trabalham com os objetivos da educação não formal em Astronomia - observatórios, planetários e clubes de astronomia - podem apresentar um potencial ainda pouco explorado em nosso país.

O aumento das pesquisas na área de educação não formal, embora em quantidade relativamente reduzida no Brasil, deve-se ao crescimento do movimento de divulgação científica nos últimos anos, inclusive no Brasil, que vem contribuindo para o movimento de alfabetização científica, segundo Marandino et al. (2004). Por isso, essa autora alerta para a necessidade de se discutir as formas e as estratégias pela qual a divulgação científica vem ocorrendo fora do espaço escolar, o que tem produzido um

1 Unesp - Universidade Estadual Paulista - Faculdade de Ciências/campus de Bauru. Doutorando do Programa de Pós-Graduação em Educação para a Ciência. Grupo de Pesquisa em Ensino de Ciências. E-mail: rlanghi@fc.unesp.br

2 Unesp - Universidade Estadual Paulista - Faculdade de Ciências/campus de Bauru. Professor Adjunto - Depto de Educação - Grupo de Pesquisa em Ensino de Ciências - Programa de Pós-Graduação em Educação para a Ciência. E-mail: nardi@fc.unesp.br. 
crescimento no volume de pesquisas na área de educação em ciências extraescolar. Museus de ciências e locais semelhantes (incluindo planetários e observatórios astronômicos) têm sido lócus importante das investigações no campo do Ensino de Ciências, e vários trabalhos têm procurado discutir os aspectos educativos desenvolvidos nesses espaços, incluindo fundamentações teóricas da área de formação de professores, como é o caso do estudo realizado por Jacobucci (2006) em onze instituições brasileiras de divulgação científica (centros e museus de Ciências), que mostrou as tendências de seus 14 programas de formação (cursos de curta duração e programas efetivos de formação continuada mais longos): eles estão cada vez mais baseados na reflexão sobre a prática, na autonomia docente e na compreensão dos problemas educacionais em um contexto sociopolítico e histórico mais amplo. Os programas de formação oferecidos por essas instituições apresentam o predomínio de dois modelos diferentes de formação: o prático-reflexivo e o emancipatório-político. Seis desses programas se enquadram no modelo prático-reflexivo, fundamentado na linha da epistemologia da prática em que o professor aprende com a própria prática e é visto como um indivíduo capaz de pensar sobre as ações pedagógicas que realiza (Tardif, 2004; Schön, 1983; Zeichner, 1993). O modelo emancipatório-político focaliza a possibilidade de autonomia do professor e sua capacidade de se tornar crítico em relação ao próprio trabalho e ao mundo. Outros seis programas analisados se enquadram no modelo clássico ou tradicional de ensino.

Mas como definimos a educação não formal? Com caráter sempre coletivo (Gohn, 1999), esta tipologia de educação envolve práticas educativas fora do ambiente escolar, sem a obrigatoriedade legislativa, nas quais o indivíduo experimenta a liberdade de escolher métodos e conteúdos de aprendizagem (Chagas, 1993). Alguns exemplos de locais que oferecem a educação não formal são: museus, meios de comunicação, agências formativas para grupos sociais específicos, organizações profissionais, instituições não convencionais de educação que organizam eventos tais como cursos livres, feiras e encontros (Silva e Carneiro, 2006; Libâneo, 2005).

No entanto, a educação não formal também não está livre de um determinado grau de intencionalidade e sistematização. Embora a educação não formal venha ganhando nova caracterização - pois, de acordo com Marandino et al. (2004), há a falta de consenso na literatura nacional na definição 
deste termo -, podemos considerar de modo sintético, neste texto, que esse tipo de educação se caracteriza por qualquer atividade organizada fora do sistema formal de educação. No caso específico dos objetivos deste capítulo, os planetários, observatórios astronômicos e clubes de astrônomos amadores, que oferecem tais atividades, podem ser incluídos na listagem de estabelecimentos de educação não formal em Astronomia, cujas potencialidades formativas serão brevemente consideradas neste texto.

\section{Observatórios astronômicos}

Os observatórios astronômicos constituem-se em locais destinados à pesquisa científica (observatórios profissionais), ao ensino e divulgação (observatórios públicos, didáticos ou alguns ligados a universidades) e à prática amadora ou hobby (observatórios particulares). Normalmente, são construídos em locais de maiores altitudes e afastados dos grandes centros urbanos, amenizando a poluição luminosa e ganhando campo de visão do céu. Suas atividades observacionais na luz visível dependem das condições atmosféricas locais, mas geralmente há trabalhos alternativos durante noites totalmente nubladas ou chuvosas.

A maioria dos observatórios públicos e de universidades oferece cursos de curta duração em Astronomia para professores e ao público, abrindo suas dependências para visitações, além de desenvolver trabalhos sérios na área da Astronomia Observacional. No Brasil, a maioria dos observatórios com características amadoras participa os seus resultados com uma rede virtual nacional, a Rede de Astronomia Observacional (REA), socializando e sistematizando os dados levantados.

Segundo Dyson (1992), o local de trabalho dos astrônomos também é alvo de peregrinação de membros do público interessado, que vão às montanhas em busca de belezas naturais e que observam o céu com visão apreciativa de beleza natural, apreciando-o cada vez mais à medida que aumenta o seu conhecimento sobre Astronomia. Assim, conforme este autor, enquanto os astrônomos se derem ao trabalho de partilhar o seu trabalho com o público, este providenciará que o trabalho deles continue.

Por exemplo, em uma pesquisa a respeito da importância da reflexão sobre a prática de ensino durante a formação inicial, Baptista (2003) en- 
caminha futuros professores a discutirem a importância das atividades de observatórios e planetários localizados na comunidade local, permitindo aos aprendizes uma maior facilidade em estudar de perto os corpos celestes, observando o céu real no observatório, e o céu artificial no planetário por meio da simulação do posicionamento das estrelas, conhecendo mais sobre a história da Astronomia. Tais locais possuem a função de atuar como um centro de pesquisa, difusão e ensino no campo das ciências astronômicas, astrofísicas, atmosféricas e sensoriamento remoto, desenvolvendo atividades com professores e estudantes dos Ensinos Fundamental, Médio e Superior, destacando-se as observações astronômicas ao vivo, aulas, cursos, palestras e projeções de vídeo (Baptista, 2003).

\section{Planetários}

Os planetários, por sua vez, diferenciam-se dos observatórios sob muitos aspectos. Um deles é que não dependem das condições climáticas do céu para funcionar, pois o céu que se visualiza nesses estabelecimentos não é real, mas uma projeção mediante um sistema óptico associado a uma sequência de apresentação gravada, ou ao vivo, reproduzida em amplificadores de som, com ou sem efeitos musicais e sonoros. As apresentações de planetários independem também do local onde são instalados, pois o "céu" observado é o resultado de projeções de imagens em uma cúpula interna (anteparo) envolvendo $180^{\circ}$ de sua área superior interna, portanto, em uma semiesfera $\left(180^{\circ} \times 360^{\circ}\right)$, em uma espécie de cinema $360^{\circ}$.

Os planetários são amplamente utilizados em diversos países e constituem-se em espaços de ensino, divulgação e cultura científica, proporcionando apresentações e aulas práticas sobre o Universo para escolas, alunos, professores e público, debaixo de um céu artificialmente estrelado, com abordagens de uma variedade de temas científicos, reproduzindo a aparência do céu em qualquer época do passado ou futuro e conforme observado em qualquer lugar do planeta.

Os visitantes são acomodados sentados em poltronas inclinadas de modo a observar o "céu" artificialmente projetado na superfície interna da cúpula, com imagens estáticas e em movimento, de modo a criar situações de ensino-aprendizagem, ao mesmo tempo em que ocorrem intervenções 
que procuram despertar a curiosidade científica e a mobilização para a conscientização ambiental planetária mediante o uso de estratégias de motivação durante as sessões em uma combinação de efeitos sonoros e visuais. Utilizando os recursos digitais, sonoros e de computação gráfica do planetário, é possível explorar virtualmente os corpos do sistema solar (planetas, luas, cometas, asteroides etc.); investigar outras estrelas, nebulosas, aglomerados estelares e galáxias; estudar constelações atuais, antigas ou de outras culturas e nações; viajar para outras localidades na superfície da Terra e verificar o céu de outros países; simular o pouso em outros corpos celestes; criar fenômenos astronômicos, como eclipses solares e lunares, chuvas de meteoros, ocultações, fases da Lua, estações do ano, crepúsculos etc.

Além da Astronomia, os recursos didáticos de um planetário dessa natureza interagem o visitante ou aluno com as demais áreas do saber, promovendo a interdisciplinaridade, tais como o Meio Ambiente, Biologia, Matemática, Poesia, Literatura, Mitologia, História, Artes, Estudos Sociais, e calendários, mostrando na cúpula as relações entre cultura e céu, as diferentes crenças de povos primitivos e a visualização distinta que tinham do céu em diversos locais da superfície terrestre, desenvolvendo discussões sobre as diferentes maneiras de contar o tempo conforme as diferentes sociedades humanas e suas relações com o movimento da esfera celeste e dos astros localmente visíveis, e muitos outros exemplos de oportunidades de recursos utilizáveis a fim de se enriquecer os conteúdos escolares (Curran, 1990). Desta maneira, conforme Szostak (1990), os alunos acabam sendo muito motivados por visitarem um planetário.

Por promoverem um ensino motivador, os planetários procuram transformar $\mathrm{o}$ ato de aprender em momentos marcantes, gerando algum tipo de prazer. Conforme Pietrocola (2005), esses conhecimentos marcantes, e que nos acompanham durante toda a vida, são aqueles que cumprem dois requisitos fundamentais: são úteis e geram algum tipo de prazer. Seguindo esse raciocínio, os conhecimentos científicos, incluindo a Astronomia, tentam ser trabalhados nos planetários de tal modo que os alunos derivem sensações e sentimentos de prazer em aprendê-los, gerando motivações intrínsecas (Sansone e Harackiewicz, 2000; Deci e Ryan, 1985; Harter, 1981; Lepper, Corpus e Iyengar, 2005) e despertando sua curiosidade e interesse científicos, mesmo que tais conhecimentos não aparentem, aos estudantes, ter alguma utilidade prática para o momento. 
De fato, a ação motivadora desses ambientes não escolares de ensino pode oferecer situações de aprendizagem que geram interesse por parte dos alunos. Refletindo sobre o papel da motivação no ensino de conteúdos, Guimarães e Boruchovitch (2004) discutem as implicações da Teoria da Autodeterminação, proposta com o objetivo de compreender os componentes da motivação intrínseca e extrínseca e os fatores relacionados com a sua promoção, ainda pouco difundida no Brasil. Sob o ponto de vista dessa teoria, três necessidades psicológicas inatas e subjacentes à motivação intrínseca são necessárias: a necessidade de autonomia, a necessidade de competência, e a necessidade de pertencer ou de estabelecer vínculos. Deste modo, a motivação intrínseca do estudante não resulta de treino ou de instrução, mas pode ser influenciada principalmente pelas ações do professor na escola ou da pessoa que assume o papel de instrutor ou educador em ambientes não escolares. Por outro lado, embora o seu estilo motivacional de ensinar seja considerado uma característica vinculada à personalidade, este é também vulnerável a fatores sociocontextuais, como, por exemplo, o número de alunos em sala de aula, o tempo de experiência no magistério, o gênero, a idade, as interações com a direção da escola, as concepções ideológicas, a interação com seus alunos, entre outros (Guimarães e Boruchovitch, 2004).

Porém, além do aspecto motivacional, os planetários, para Curran (1990), apresentam outra função: o ensino. E, segundo Barrio (2007), esses estabelecimentos propõem uma finalidade dupla: a educação e a cultura científica. Para isso, eles podem dispor de apresentações com conteúdo científico dotado de recursos modernos com uso de tecnologia avançada, tornando cada vez mais atraente a busca dessa finalidade proposta. No entanto, para o autor, embora o aspecto cultural tenha sido atingido pela maioria dos planetários brasileiros, a abordagem educativa ainda tem um longo caminho pela frente, pois a maioria dos planetários modernos parece ter sido concebida mais para lazer que para ensino e aprendizagem. Contudo, o objetivo principal de um planetário deve ser o de educar nas diferentes áreas do conhecimento a partir dos princípios astronômicos. De fato, o enorme potencial pedagógico de um equipamento como o planetário é amplamente reconhecido na área (Nogueira, Lottis e Loss, 2008), embora muitos nem saibam o que seja, de fato, um planetário, inclusive professores (Szostak, 1990). 
Por esta razão, os planetários deveriam representar a maior e mais eficiente interface entre a Astronomia profissional e os professores (Franknoi, 1990). Os planetários não deveriam funcionar apenas como momentos de lazer ou como rápidas sessões de cultura científica, mas também como parceiros na formação continuada em ensino de Astronomia para os professores dos Ensinos Fundamental e Médio, promovendo cursos, distribuição de materiais didáticos e o atendimento local e regional, dirigindo-se pessoalmente até as escolas, em uma somatória de esforços de modo a atingir todo o País. Porém, no Brasil, devido à quantidade reduzida dessas instituições de divulgação e ensino (há, atualmente, cerca de 30 planetários fixos em funcionamento em todo o território nacional), a prática dessas atividades parece estar distante de nossa realidade, apesar de alguns planetários brasileiros promoverem excelentes trabalhos locais e sobretudo pontuais.

A importância dos planetários, segundo Clarke (1990), está em servir à comunidade desempenhando os seguintes papéis: a) popularizam a Astronomia e a Ciência Espacial; b) oferecem suporte ao sistema educacional formal sobre o ensino da Astronomia e temas relacionados; c) representam à comunidade uma fonte segura de informações em Astronomia. Contudo, conforme o autor, nem todos os planetários incorporam todos esses papéis ao mesmo tempo ou nos mesmos graus de importância. As escolas podem e devem usar os planetários para as auxiliar com o currículo no que tange ao ensino de conteúdos específicos de Astronomia, usando ou não suas apresentações públicas. Algumas sessões poderiam ser especialmente preparadas em conjunto com os professores envolvidos, a fim de se atingir suas reais necessidades formativas. Há também os planetários portáteis e itinerantes, que são dedicados exclusivamente às atividades escolares e educacionais, pois, em geral, são montados em escolas (Clarke, 1990).

Pensando no ensino de professores, de alunos e do público em geral, Szostak (1990) recomenda a cooperação entre universidades e planetários. E, ao passo que apresentam diferentes sofisticações tecnológicas em seus aparelhos projetores e suas apresentações, a maior preocupação é conhecer antecipadamente o público que será atendido e suas necessidades por meio de técnicas e instrumentos apropriados de pesquisa e uma boa comunicação com o público-alvo (Clarke, 1990). Em espetáculos públicos, os planetários não deveriam oferecer explicações de conteúdos profundos e complexos em Astronomia, pois isto poderia gerar insatisfações e uma reputação inade- 
quada para o local, lembrando que uma apresentação pública não é uma aula específica, e nem se espera atender a um público homogêneo (Clarke, 1990).

Para uma visita em um planetário ser eficiente, é necessária a preparação antecipada, informando aos visitantes o que é um planetário e como é usado, ensinando brevemente alguns termos específicos que serão falados na apresentação, tais como: rotação, coordenadas, pontos cardeais etc. Quando se tratar de escolas, um trabalho antecipado com atividades poderá ser desenvolvido juntamente com o professor na própria sala de aula. Após as apresentações, um tempo deve ser destinado para perguntas dos visitantes, e o operador deve responder visualmente e na prática, manipulando com eficiência os projetores do planetário (Szostak, 1990).

Pensar nas estratégias de ensino em um planetário é fundamental para beneficiar os envolvidos. Por exemplo, Bishop (1990) mostra que a apresentação de um planetário não deve ser passiva, mas deveria assumir características de uma aula participativa, ainda mais ao se atender alunos e professores, partindo-se do pressuposto de que há o interesse em aprender por parte dos que se deslocaram até aquele local. Algumas estratégias apresentadas pela autora são: a utilização de desenhos e figuras (por meio da análise dos desenhos das crianças, é possível inferir interpretações pedagógicas e psicológicas de aprendizagem sobre estrelas, planetas e suas posições no espaço); o uso do questionamento interativo (o instrutor descobre antecipadamente as características do público, tais como suas preconcepções, sua capacidade de abstração e suas dificuldades com relação a habilidades de percepção visual, tal como o caso da Lua crescente no céu apresentar o formato da letra "C" ou "D", dependendo de como o observador posiciona a cabeça para observa-la, ou de sua localização hemisférica na superfície da Terra); o uso de modelos materiais concretos (feixe intenso de luz e esferas de isopor podem ser usados como atividades interativas dentro da cúpula escura do planetário para o ensino de diversos conceitos, tais como fases da Lua, estações do ano, movimentos dos planetas, noções de esfera celeste etc.); o uso das músicas e histórias infantis (além de educativo, isto pode representar momentos lúdicos para as crianças, por meio da exploração de sua criatividade e capacidade de memorização consciente de conteúdos específicos básicos, tais como direções, localização, mitologia, fases da Lua, dia e noite etc.). 
Incentivando a visita aos espaços não escolares e visando um aprendizado prático do conteúdo em Astronomia, os documentos oficiais da educação brasileira, os PCN (Parâmetros Curriculares Nacionais), salientam a necessidade de "atividades práticas e visitas preparadas a observatórios, planetários, associações de astrônomos amadores, museus de Astronomia e de Astronáutica” (Brasil, 1999). Mas Delizoicov et al. (2002) alerta que esses espaços não devem ser encarados só como oportunidades de atividades educativas complementares ou de mero lazer, mas devem fazer parte do processo de ensino/aprendizagem de forma planejada, sistemática e articulada.

Embora a quantidade de pesquisas sobre a aprendizagem em museus, planetários e observatórios tenha aumentado, ela ainda pode ser considerada relativamente escassa. As pesquisas nesses espaços não escolares vêm ocorrendo em uma abordagem do ensino informal, com resultados que apontam que esses centros de Ciências contribuem para alterações do procedimento e atitude, mas não tanto no sentido conceitual. Outras pesquisas sobre aprendizagem, especificamente em planetários, embora em número bastante reduzido no Brasil, demonstram que os conteúdos conceituais também podem ser trabalhados (Barrio, 2007).

\section{Associações de Astronomia Amadora}

Refletindo sobre a natureza da Ciência Astronômica, essencialmente observacional, os PCN contemplam, ainda, a importância das observações no ensino das Ciências, pois "observar não significa apenas ver, e sim buscar ver melhor, encontrar detalhes no objeto observado” (Brasil, 1997). Há duas maneiras de se fazer uma observação. A primeira é o contato direto com os objetos de estudo, e a segunda é "mediante recursos técnicos ou seus produtos. São os casos de observações feitas por meio de microscópio, telescópio, fotos, filmes ou gravuras" (Brasil, 1997). Denota-se, portanto, uma importância considerável em incluir observações do céu através de telescópios no Ensino de Ciências, e não apenas a olho nu.

Recomendando a utilização de tais instrumentos no ensino da Astronomia e Ciências afins, Beatty (2000) concluiu que muitos alunos e professores ficam dotados de mais incentivo e motivação de aprendizagem do conhecimento científico ao observar as imagens reais do universo através 
de um telescópio - experiência nunca vivenciada por muitos professores. Townsend (1998) relata que o uso de telescópios na educação em Ciências pode habilitar o professor a incorporar uma experiência astronômica real, por meio da observação direta de corpos celestes fascinantes, tais como nebulosas, estrelas duplas, aglomerados, galáxias, planetas, cometas, crateras e montanhas da Lua etc. Isto tem motivado o estudante e o próprio educador, levando-os a se envolver mais com outras questões fundamentais do universo, uma vez que "os fenômenos astronômicos fornecem um farto material de observações que pode ser trabalhado e conduzido a um modelo científico do fenômeno" (Nascimento, 1990). De fato, pesquisas na área da Educação em Astronomia têm revelado a importância do uso do telescópio no ensino e nos processos formativos docentes (Gould, Dussault e Sadler, 2007; Torres, 2004; Mallman e Rasia, 2000; Ormeno, 2000).

O exemplo do próprio Galileu Galilei ilustra bem o efeito revolucionário que uma observação telescópica pode provocar. Embora ele não tenha sido o primeiro a realizar observações celestes pelo telescópio, nem o inventor deste instrumento, cabe-lhe o mérito do uso sistemático deste instrumento para a obtenção de dados que embasaram revoluções científicas. Apesar de estar familiarizado com muitos aspectos dos conceitos em Astronomia, Galileu Galilei talvez tenha ficado impressionado com o que viu pela primeira vez através do telescópio ao apontá-lo para o céu noturno. A maioria dos alunos e professores fica igualmente encoberta de fascinação ao observar por meio deste instrumento, em uma aproximação razoável, as montanhas, cordilheiras, vales e crateras da Lua, de quilômetros de extensão; os planetas gigantes Júpiter, com suas nuvens coloridas na alta camada da atmosfera e suas quatro luas principais mudando de posição, e Saturno, com seus característicos anéis; enormes aglomerados estelares, como Ômega Centauri, com seus milhões de estrelas assemelhando-se a um enxame; estrelas duplas que a olho nu aparecem como uma única no céu; estrelas de diferentes cores e brilhos devido às diferenças de temperatura de sua superfície, e assim por diante.

Assim, tendo em vista a importância do uso do telescópio na educação como fator propulsor da curiosidade científica nos alunos, torna-se passível de indignação o fato de relativamente poucas escolas possuírem no mínimo sua própria luneta ou um simples binóculo. Por sua vez, quando a escola (ou simplesmente uma pessoa interessada) finalmente decide adquirir um 
instrumento assim, talvez com o tempo caia no desuso, porque não há professores habilitados para operar o aparelho, ou não se sentem aptos para manuseá-lo na direção apropriada do céu noturno onde se encontram os corpos celestes mais fascinantes e motivadores, como nebulosas, estrelas duplas, aglomerados, galáxias e os planetas do Sistema Solar.

Talvez o motivo de não se encontrar com frequência um telescópio nas escolas esteja no fato de que este é um instrumento de uso principalmente noturno (horário em que as crianças normalmente não vão à escola). Porém, Tignanelli (1998) salienta que, durante o dia, poderiam ser realizadas observações telescópicas de manchas solares e da Lua minguante ou crescente, tomando-se as devidas precauções ópticas de proteção contra o brilho solar excessivo durante o dia. Além disso, eventos noturnos especiais na escola poderiam ser marcados, envolvendo as famílias, durante o período em que ocorrerem fenômenos astronômicos de destaque, tais como os eclipses, por exemplo, ou para noites comuns de observação do terminador lunar ou de um planeta.

Neste sentido, os clubes de Astronomia e associações de Astronomia Amadora, no Brasil, poderiam empenhar-se seriamente em criar e desenvolver o interesse e a curiosidade da população pela pesquisa, ensino e extensão da Astronomia e Ciências afins, sobretudo quando são vinculados ou instalados em instituições de ensino superior de formação de professores. Essas instituições poderiam prestar uma valiosa contribuição para a popularização e o ensino da Astronomia, suprimindo carências específicas nesta área, mesmo que realizado muitas vezes de modo pontual e isolado ou sob o domínio de conhecimento obtido à base pessoal, como fruto de leituras autodidatas, sem formação específica na maioria dos seus membros (Trevisan, 2004; Brandão, 2006).

De fato, a Astronomia talvez seja a única ciência em que amadores contribuem significativamente com dados e informações para a comunidade científica profissional, uma vez que astrônomos profissionais ocupam-se intensamente com trabalhos bem específicos e segmentados da Astronomia, sem observações diretas através das oculares de telescópios instalados em alguns observatórios de consórcios internacionais, enquanto os amadores aficionados observam ativamente com seus próprios telescópios, muitas vezes nos fundos de suas residências, espalhados por todo o globo terrestre, perscrutando o céu noturno (Dyson, 1992). 
Muitos foram os campos das contribuições de astrônomos amadores, tais como descobertas de novos cometas, estrelas novas e supernovas, estudo e descoberta de asteroides, monitoramento de estrelas variáveis, registro de manchas solares, impactos lunares ou o estudo sistemático de atmosferas planetárias, apenas para citar alguns exemplos, pois esta abrangência não é o objetivo deste texto (Dyson, 1992; Phillips, 2008; Romero, 2007; Trevisan, 2004; Sánchez-Lavega, 2007).

Em muitos países, como a Itália e a Polônia, o papel de sociedades e associações de astrônomos amadores, comprometidos com o conhecimento de cunho científico, tem sido fundamental para a formação continuada de professores em conteúdos de Astronomia e para mudanças educacionais no sistema de ensino de Ciências em seus países, por meio de sua influência sobre os órgãos governamentais, promovendo a colaboração entre seus membros, compostos de astrônomos profissionais, astrônomos amadores e professores. De fato, a atuação de clubes e associações de astrônomos amadores é decisiva e, muitas vezes, o principal meio para a divulgação e educação não formal em Astronomia, visando a população e professores (Pestellini, 1990; Iwaniszewska, 1990).

Com trabalhos contextualizados e embasados em resultados de pesquisas da área, os clubes de Astronomia Amadora no Brasil também poderiam contribuir significativamente para a prática docente, principalmente quando não há a disponibilidade de observatórios ou planetários em determinadas regiões onde há escolas, tornando tais clubes os únicos estabelecimentos confiáveis como fonte de informações a respeito de conteúdos de Astronomia e de posse de telescópios, mapas e materiais didáticos, constituindo-se em um notável apoio ao educador. Não se pode negar, portanto, esse potencial existente em nosso território nacional.

\section{Considerações finais}

O incentivo maior desses tipos de atividades não formais deveria, a nosso ver, partir das próprias universidades e das instituições formadoras de professores, comprometidas com os resultados de pesquisas sobre a educação em Astronomia. No entanto, apesar de todas as características distintivas da Astronomia, sobretudo a sua natureza basicamente observacional, 
diversos cursos de graduação do País, mesmo os poucos que possuem sua estrutura curricular contemplando conteúdos de Astronomia introdutória, não atribuem a esta prática a sua devida importância. Segundo indicam Bretones e Compiani (2001), apenas 40\% das instituições de Ensino Superior (as que possuem Astronomia em seu currículo) apresentam atividades práticas e observacionais sobre a Astronomia. A não menção das demais instituições poderia inferir na sua concentração conteudista de aulas teóricas sobre temas de Astronomia, bem como na ausência de comprometimento com a prática astronômica, que envolveriam observações celestes a olho nu e com telescópios, astrofotografias, práticas de determinação de fatores astronômicos, visitas a observatórios e planetários, construção de maquetes, aulas de laboratório etc.

Lembramos, ainda, da importância do papel conjunto exercido pelas associações amadoras, observatórios e planetários em se mobilizar coletivamente para promover mudanças e pressionar setores governamentais da educação no sentido de incitar atitudes que resultem em reformas nacionais para o desenvolvimento da pesquisa, ensino e popularização da Astronomia. Esse tipo de ação unificadora, movimentando-se em sentido contrário à dispersão e pulverização de esforços locais desses estabelecimentos, coloca-se em favor do desenvolvimento da educação em Astronomia e de sua pesquisa e justifica-se pelo fato de essa ciência desenvolver o importante papel em promover no público o interesse, a apreciação e a aproximação pela Ciência em geral, pois normalmente surgem questões de interesse comum que despertam a curiosidade das pessoas, tais como buracos negros, cosmologia e exploração do Sistema Solar, levando-as a uma educação em Astronomia, mesmo que não formal.

Portanto, pensando em como os astrônomos poderiam colaborar para o incentivo da educação dessa ciência, Viegas (1998) faz um diagnóstico da Astronomia no Brasil e mostra que se deve ter a preocupação de promover a habilidade nos astrônomos em despertar a cidadania no País, pois esta implicará na necessidade crescente da defesa das ciências básicas, em particular da Astronomia, com base no esclarecimento da população em geral, com explicações de sua importância para o desenvolvimento nacional. Outra preocupação é identificada por Bretones e Compiani (2001), a saber, aumentar o debate sobre o papel da Astronomia introdutória na maioria das instituições de Ensino Superior brasileiras, pois muitos alunos dessas 
disciplinas podem vir a se tornar professores de Ciências, Física, Geografia e outras disciplinas nos Ensinos Fundamental e Médio. Por isso, mais trabalhos e artigos devem ser publicados para enriquecer esta discussão, a fim de aproximar a Astronomia do ensino, em uma tentativa de aprimorar a formação dos professores e estudantes. E mesmo que sua formação inicial não dê conta de todos os conteúdos desta natureza, deve-se pensar na busca de programas de formação continuada que contemplem a pesquisa sobre a educação em Astronomia e que sejam adequados às reais necessidades formativas dos docentes participantes.

\section{Referências bibliográficas}

BAPTISTA, G. C. S. A importância da reflexão sobre a prática de ensino para a formação docente inicial em ciências biológicas. Revista Ensaio, São Paulo, v.5, n.2, pp.4-12, out. 2003.

BARRIO, J. B. M. Planetários recuperam as noites urbanas. Astronomy Brasil, São Paulo, v.2, n.14, pp.68-69, jun. 2007.

BEATTY, K. Where are the Young astronomers? Sky E Telescope. Estados Unidos da América. Skypub, v.100, n.3, pp.82-86, set. 2000.

BISHOP, J. E. The role of the planetarium: process and practice. In: PASACHOFF, J.; PERCY, J. (Orgs.). The teaching of astronomy. Cambridge: U. Press, 1990.

BRANDÃO, H. Censo astronômico 2005. Revista Macrocosmo, ano IV, ed.37, pp.2-6, dez. 2006. Disponível em: < http://www.revistamacrocosmo.com/ edicoes/download/pdf/macrocosmo37.pdf>. Acesso em: 10 jul. 2008.

BRASIL. Secretaria de Educação Média e Tecnologia. Parâmetros Curriculares Nacionais: ciências naturais. Brasília: MEC/SEMTEC, 1997.

BRASIL. Secretaria de Educação Média e Tecnologia. Parâmetros Curriculares Nacionais: Ciências da natureza, matemática e suas tecnologias. Brasília: MEC/ SEMTEC, 1999.

BRETONES, P. S.; COMPIANI, M. Disciplinas introdutórias de astronomia nos cursos superiores do Brasil. Boletim da Sociedade Astronômica Brasileira, v.20, n.3, pp.61-82, 2001.

CHAGAS, I. Aprendizagem não formal/formal das ciências: relações entre museus de ciência e as escolas. Revista de Educação, Lisboa, v.3, n.1, pp.51-59, 1993.

CLARKE, T. R. The role of the planetarium: philosophy and directions in planetarium programming. In: PASACHOFF, J.; PERCY, J. (Orgs.). The teaching of astronomy. Cambridge: U. Press, 1990. 
CURRAN, B. The role of the planetarium: the pre-college planetarium. In: PASACHOFF, J.; PERCY, J. (Orgs.). The teaching of astronomy. Cambridge: U. Press, 1990.

DECI, E. L.; RYAN, R. H. Intrinsic motivation and self determination in human behavior. New York: Plenum Press, 1985.

DELIZOICOV, D. et al. Ensino de ciências: fundamentos e métodos. São Paulo: Cortez, 2002.

DYSON, F. De eros a gaia. São Paulo: Best Seller, 1992.

FRAKNOI, A. The universe in the classroom: a newsletter on astronomy for teachers. In: PASACHOFF, J.; PERCY, J. (Orgs.). The teaching of astronomy. Cambridge: U. Press, 1990.

GOHN, M. G. Educação não formal e cultura política. São Paulo: Cortez, 1999.

GOULD, R; DUSSAULT, M; SADLER, P. What's Educational about Online Telescopes?: Evaluating 10 Years of MicroObservatory. The Astronomy Education Review, Issue 2, v.5, pp.127-145, 2007.

GUIMARÃES, S. E. R.; BORUCHOVITCH, E. O estilo motivacional do professor e a motivação intrínseca dos estudantes: uma perspectiva da teoria da autodeterminação. Psicologia: Reflexão e Crítica, v.17, n.2, pp.143-150, 2004.

HARTER, S. A new self-report scale of intrinsic versus extrinsic orientations in classroom: motivational and informational components. Developmental Psychology, v.17, pp.300-312, 1981.

IWANISZEWSKA, C. The contribution of amateur astronomers to astronomy education. In: PASACHOFF, J.; PERCY, J. (Orgs.). The teaching of astronomy. Cambridge: U. Press, 1990.

JACOBUCCI, D. F. C. A formação continuada de professores em centros e museus de ciências no Brasil. Tese de doutorado. Campinas: Faculdade de Educação da Unicamp, 2006.

LEPPER, M. R.; CORPUS, J. H.; IYENGAR S. S. Intrinsic and extrinsic motivation orientations in the classroom: age differences and academic correlates. Journal of Educational Psychology, v.97, pp.184-196, 2005.

LIBÂNEO, J. C. Pedagogia e pedagogos, para quê? 8. ed. São Paulo: Cortez, 2005.

MALLMANN, J. A. H.; RASIA, L. A. A astronomia como eixo orientador e motivador de conteúdos do ensino médio de física. Boletim da $S A B$, v.20, n.1, 2000.

MARANDINO, M. et al. A Educação Não Formal e a Divulgação Científica: o que pensa quem faz? In: MOREIRA, M. A. (Org.). ENCONTRO NACIONAL DE PESQUISA EM ENSINO DE CIENAIAS - ENPEC, 4, 2003, Bauru. Atas... Bauru: Unesp, 2003.

NASCIMENTO, S. S. Um curso de gravitação para professores de primeiro grau. Dissertação (Mestrado). São Paulo, Instituto de Física/Faculdade de Educação, USP, 1990. 
NOGUEIRA, C.; LOTTIS, D. K.; LOSS, L. H. Os fundamentos em astronomia para atividades de ensino em um planetário por futuros professores de física. Ensaio de artigo disponível na homepage da ABP. Disponível em: <http://www. planetarios.org.br/ensaios/ensaio02.pdf>. Acesso em: 5 jul. 2008.

ORMENO, M. I. A. Evolución histórica de los telescopio en chile y metodología para estimular en los alumnos de la enseñanza media su interes por el conocimiento del universo. Boletim da SAB, v.20, n.1, 2000.

PESTELLINI, M. E. D. The didactic activities of the Italian Astronomical Society. In: PASACHOFF, J.; PERCY, J. (Orgs.). The teaching of astronomy. Cambridge: U. Press, 1990.

PHILLIPS, T. Amateur Astronomers See Perseids Hit the Moon. NASA Science News. 2 de setembro de 2008. Disponível em: <http://science.nasa.gov/headlines/y2008/02sep_lunarperseids.htm?list205943>. Acesso em: 3 set. 2008.

PIETROCOLA, M. Construção e realidade: o papel do conhecimento físico no entendimento do mundo. In: PIETROCOLA, M. (Org.). Ensino de física: conteúdo, metodologia e epistemologia em uma concepção integradora. 2. ed. Florianópolis: Editora da UFSC, 2005.

ROMERO, T. Aumento inexplicável. Boletim da Agência Fapesp, São Paulo, 21 de nov. 2007. Disponível em: <http://www.agencia.fapesp.br/materia/8048/ especiais/aumento-inexplicavel.htm\#>. Acesso em: 29 ago. 2008.

SÁNCHEZ-LAVEGA, A. et al. Depth of a strong jovian jet from a planetaryscale disturbance driven by storms. Nature, v.451, pp.437-440, 29 nov. 2007. Disponível em: <http://www.nature.com/nature/journal/v451/n7177/full/ nature06533.html\#a14>. Acesso em: 20 jan. 2008.

SANSONE, C.; HARACKIEWICZ, J. M. Intrinsic and Extrinsic Motivation: the search for optimal motivation and performance. EUA: Academic Press, 2000. SCHÖN, D. A. The reflective practitioner. How professionals think in action. New York: Jossey-Bass Publishers, 1983.

SILVA, M. R.; CARNEIRO, M. H. S. Popularização da Ciência: análise de uma situação não formal de ensino. In: REUNIÃO ANUAL DA ANPED / EDUCAÇÃO, CULTURA E CONHECIMENTO NA CONTEMPORANEIDADE: DESAFIOS E COMPROMISSOS, 29, 2006, Caxambu, MG. 29. Portal e Anais... Caxambu, MG: ANPEd, 2006.

SZOSTAK, R. The role of the planetarium: teaching teachers in the planetarium. In: PASACHOFF, J.; PERCY, J. (Orgs.). The teaching of astronomy. Cambridge: U. Press, 1990.

TARDIF, M. Saberes docentes e formação profissional. 4.ed. Petrópolis: Vozes, 2004.

TIGNANELLI, H. L. Sobre o ensino da astronomia no ensino fundamental. In: WEISSMANN, H. (Org.). Didática das ciências naturais: contribuições e reflexões. Porto Alegre: Artmed, 1998.

TORRES, J. R. Urban Astronomy in the Philippines. The Astronomy Education Review, Issue 1, v.3, pp.115-124, 2004. 
TOWNSEND, G. Using telescopic observations in undergraduate astronomy courses. The Physics Teacher, v.36, pp.304-305, maio 1998.

TREVISAN, E. J. A importância da astronomia amadora e o trabalho da REA no Brasil. Revista CIÊNCIAONLINE, ano 03, n.9, fev. 2004. Disponível em: $<$ http://www.cienciaonline.com.br>. Acesso em: 03 mar. 2005.

VIEGAS, S. M. M. Um diagnóstico da astronomia brasileira. Boletim da Sociedade Astronômica Brasileira, v.17, n.2, pp.5-16, 1998.

ZEICHNER, K. A formação reflexiva de professores: ideias e práticas. Lisboa: EDUCA, 1993. 



\section{5 \\ Ensino de Física, analogias e a dinâmica DO CONTEXTO INTERATIVO DISCURSIVO EM SALA DE AULA}

Fernanda Cátia Bozelli ${ }^{1}$

Roberto Nardi ${ }^{2}$

\section{Introdução}

Discutir as relações entre linguagem, ensino e aprendizagem, em especial aquelas que envolvem a construção de conhecimentos por professores e alunos por meio de interações discursivas em sala de aula, tem sido objeto de inúmeras investigações nos últimos anos (Edwards, Mercer, 1988; Coll, Edwards, 1998; Cindra, Teixeira, 2005).

Os processos interativos em sala de aula constituem um campo de pesquisa bastante abrangente na área educacional, envolvendo psicólogos, sociólogos, linguistas e antropólogos, pois as variáveis analisadas nas investigações sobre educação são muito diferentes (Delaamont, 1987). Mas com relação às pesquisas em Educação em Ciências, podemos dizer que é a psicologia sociocultural ou sócio-histórica que tem influenciado por despertar o interesse sobre o processo de significação nas salas de aula, provocando indagações sobre como os significados são criados e desenvolvidos por meio do uso da linguagem e outros modos de comunicação (Martins, Ogborn, Kress, 1999; Mortimer, Scott, 2002).

1 Unesp - Universidade Estadual Paulista - Faculdade de Ciências/campus de Bauru. Grupo de Pesquisa em Ensino de Ciências. Programa de Pós-graduação em Educação para a Ciência.E-mail: ferboz@fc.unesp.br.

2 Unesp - Universidade Estadual Paulista - Faculdade de Ciências/campus de Bauru. Professor Adjunto - Depto. de Educação - Grupo de Pesquisa em Ensino de Ciências - Programa de Pós-Graduação em Educação para a Ciência. E-mail: nardi@fc.unesp.br.

Apoio Financeiro do Conselho Nacional de Desenvolvimento Científico e Tecnológico (CNPq) e da Fundação de Amparo à Pesquisa do Estado de São Paulo (FAPESP). 
Dessa forma, o estudo da interação social no processo de ensino e aprendizagem, bem como no desenvolvimento cognitivo humano, levando-se em consideração o caráter social, vem sendo evidenciado principalmente por meio da abordagem vigotskiana (Monteiro, Teixeira, 2004; Pontecorvo, Ajello, Zucchermaglio, 2005). Tal escolha deve-se ao fato de que o diálogo entre uma pessoa menos experiente (aluno) e outra mais experiente (professor) é considerado o instrumento com o qual as práticas de ensino-aprendizagem são realizadas. Especificamente, pode-se dizer que é por meio do diálogo que os processos de negociação de significados de objetos e de situações são manifestados (Orsolini, 2005).

Com isso, há uma sinalização dessas pesquisas sob a nova forma de conceber os processos de ensino-aprendizagem, implicando no deslocamento do entendimento individual sobre os fenômenos específicos para um novo contexto, ou seja, para um viés de construção de significados em um contexto social de sala de aula. Essa nova forma de conceber o processo de aprendizagem incorre em uma substituição da intenção de verificar como o indivíduo muda conceitualmente sua velha concepção pela cientificamente aceita, e passa a analisar como ocorre "a negociação de novos significados, em um espaço comunicativo no qual há o encontro entre diferentes perspectivas culturais, em um processo de crescimento mútuo. As interações discursivas são consideradas como constituintes do processo de construção de significados" (Mortimer, Scott, 2002, p.284).

Analisar a interação discursiva em sala de aula "é um meio privilegiado para estudar os processos educacionais quando se procura compreender os mecanismos e as condições que propiciam a construção de significados" (Coll, Edwards, 1998, p.143-144, grifo nosso). Segundo esses autores, a forma como a interação discursiva em torno do conteúdo vai sendo construída, do ponto de vista dialógico, é que vai propiciar a elaboração de aproximações ao significado e a ocorrência de um conhecimento compartilhado (Edwards, Mercer, 1988).

Isso faz com que o discurso educacional se torne, nas últimas décadas, foco de atenção por parte dos pesquisadores que investigam os processos de ensino e aprendizagem. De acordo com Mercer (1998), estudar o discurso em sala de aula é "importante porque ele está no centro do estudo psicológico do ensino e da aprendizagem, não só porque a linguagem é o principal meio de comunicação entre professores e alunos, mas também porque é um meio vital por meio do qual representamos nossos pensamentos" (p.13). 
Mas existem diferentes formas de interação professor/aluno quando se trata de construção de significados. Algumas investigações têm revelado que na interação discursiva professor/aluno tem prevalecido a estrutura comunicativa do tipo IRA (indagação, resposta, avaliação), na qual prevalece o domínio das perguntas do professor sobre o discurso da sala de aula, sendo que a maioria das perguntas feitas pelos professores não busca informação; serve apenas de armamento discursivo para controlar conteúdos de discussão, dirigir pensamentos e ações dos alunos (Edwards; Mercer, 1988).

Em algumas ocasiões, o professor lidera as discussões com toda a classe; em outras, os estudantes trabalham em pequenos grupos, e o professor desloca-se continuamente entre os grupos, auxiliando-os; em outras, o professor faz uma série de questões, e as respostas dos estudantes, na maioria das vezes, limitam-se a preencher as lacunas no discurso do professor; muitas vezes o professor é extremamente hábil nesse estilo de exposição, mas há muito pouco espaço para os estudantes fazerem e falarem algo, e muitos nunca abrem a boca (Mortimer, Scott, 2002).

Contudo, apesar de existir todas essas discussões a respeito do papel do discurso e da interação, concordamos com Mortimer e Scott (2002) quando estes expõem que são poucos os trabalhos que têm se preocupado sobre como os professores dão suporte ao processo pelo qual os estudantes constroem significados em aulas de Ciências, sobre como as interações produzidas, desenvolvidas interferem na aprendizagem dos alunos.

Ao mesmo tempo, alguns estudos também vêm destacando que uma das maneiras de facilitar a comunicação em sala de aula entre professor e aluno, de forma a tornar o conhecimento científico compreensível, é por meio do uso de diferentes (várias) figuras de linguagem, dentre as quais estão inclusas as analogias (Dagher, 1995; Godoy, 2002).

Diante disso, pretendemos avançar nessa linha de investigação ao tratar o uso de figuras de linguagem (no nosso caso, analogias), especificamente com relação à sua elaboração, utilização/exploração nos processos interativos discursivos em sala de aula de forma a verificar a influência destes na aprendizagem dos alunos.

Uma das questões que permitiram tal reflexão foi a o fato de que explicar conceitos científicos na sala de aula envolve tanto entender o conteúdo quanto ser capaz de comunicar esse conteúdo de maneira efetiva. Mas será 
que a postura assumida pelo professor no contexto interativo discursivo tem contribuído ou influenciado na elaboração/exploração da analogia em sala de aula?

De acordo com Ogborn et al (1996), "explicar envolve, além de uma análise cuidadosa dos conteúdos a serem tratados, considerar diferentes estratégias de comunicação, diferentes interesses e habilidades cognitivas dos interlocutores, a motivação, os objetivos e papéis sociais dos participantes, as restrições impostas pelo contexto etc." (p.02).

\section{Analogias em sala de aula}

A comunicação escolar, especificamente em Ciências Naturais, encontra uma série de dificuldades. Destacamos como sendo uma delas a presença de um espaço relevante entre a linguagem comum e a linguagem científica (Galagovsky, Bonán, Adúriz Bravo, 1998), também chamada "linguagem científica erudita" como aponta Galagovsky e Adúriz Bravo (2001). De acordo com esses autores, aprender Ciências implica, antes de tudo, aprender a lidar com a linguagem.

Autores como Martins, Ogborn e Kress (1999) têm mostrado a importância da linguagem e, particularmente, da explicação no ensino e na aprendizagem de Ciências. Para o aprendizado da linguagem científica, por exemplo, ressaltam a importância de se verificar as "[...] funções que metáforas, analogias e outros recursos de imaginação possuem em situações de ensino". Se partirmos da conceitualização de explicação dada por esses autores, ou seja, "explicar envolve, além de uma análise cuidadosa dos conteúdos a serem tratados, considerar diferentes estratégias de comunicação" (op. cit., p.02), percebemos que tal importância deve-se ao fato de que explicar conceitos científicos na sala de aula envolve tanto entender o conteúdo quanto ser capaz de comunicar esse conteúdo de maneira efetiva. "O conhecimento não só sofre diversas transformações até chegar à escola, mas também é continuamente transformado na escola [...] o uso de metáforas e analogias também é crucial na transformação do conhecimento” (op. cit., p.09).

Considerando que conceitos são instrumentos de assimilação por meio dos quais interpretamos e interagimos com o mundo que nos cerca, a aprendizagem de conceitos constitui elemento fundamental na Educação em 
Ciências. Segundo Mortimer e Machado (2001), a construção do conhecimento em sala de aula depende essencialmente de um processo no qual os significados e a linguagem do professor vão sendo apropriados pelos alunos, na construção de um conhecimento compartilhado. Assim, dentre os estudos sobre linguagem no Ensino de Ciências, tem sido destacado o papel das analogias na comunicação entre professores e alunos em sala de aula.

As analogias mostram-se importantes no Ensino de Ciências, visto que a maioria dos conceitos na área de Ciências - especialmente na Física - é de natureza abstrata, isto é, sua compreensão requer que os alunos sejam capazes de imaginar, modelar etc. Como esse processo não é simples, o professor sente, em algumas situações, a necessidade de utilizar uma situação mais familiar aos alunos. Nesse sentido, as analogias são utilizadas como recursos didáticos no ensino de tais conceitos, pois elas apresentam similaridades entre dois domínios diferentes, sendo que um familiar ao aluno - denominado "análogo", e outro, não familiar - chamado "alvo".

Ao mesmo tempo, as analogias podem ser consideradas como "facas de dois gumes", uma vez que, paralelamente às vantagens, podem apresentar desvantagens, como, por exemplo, uma analogia nunca está baseada em uma combinação exata entre analógico e alvo; geralmente há características do analógico que são diferentes do alvo, e isso pode induzir ao erro (Duit, 1991). Apesar de o raciocínio analógico ser comum, o uso espontâneo das analogias proporcionadas pelos professores ou alunos ainda são raros. $\mathrm{O}$ uso de analogias em situações de aprendizagem exige orientações consideráveis. Mesmo apresentando desvantagens, Orgill e Bodner (2004) recomendam que analogias devam ser usadas quando o conceito alvo é difícil de ser explicado, entendido e/ou não pode ser compreendido. Além disso, eles recomendam que elas devam ser simples e apresentar uma linguagem clara e relações entre os dois domínios que sejam facilmente compreendidas pelos alunos. Elas não devem ser usadas quando o conceito alvo é simples ou de fácil entendimento, ou quando os alunos não conseguem associar o análogo com o alvo.

Todos esses apontamentos com relação ao uso de analogias em sala de aula acabam por destacar ainda mais a importância de se investigar durante o contexto interativo discursivo entre professor e alunos como ela é explorada, uma vez que ela pode tanto contribuir quanto dificultar ainda mais o processo de construção de significados em salas de aula de Ciências. De 
acordo com Duit (1991) e Oliva (2008) "são poucos os estudos que analisam como os professores usam analogias na sua prática habitual" (p.16), especificamente na construção de saberes docentes quando da formação inicial de futuros professores. Por conta disso e das reflexões anteriores, optamos por investigar o contexto interativo discursivo de elaboração/exploração de analogias em sala de aula por futuros professores de Física. Para Duarte (2005), o fator que determina o sucesso de uma abordagem analógica em sala de aula é justamente a existência de um ambiente, ou melhor, um contexto de ensino interativo que permita o estabelecimento de relações analógicas.

Para Mortimer e Machado (2001), a compreensão do papel da linguagem na mediação dos conceitos é fundamental para redimensionar as práticas pedagógicas existentes.

\section{O processo de constituição dos dados}

A metodologia de pesquisa, de natureza qualitativa, priorizou o acompanhamento de uma amostra de 27 licenciandos de um curso de licenciatura em Física de uma universidade pública paulista. A constituição desses dados no curso de licenciatura ocorreu em duas etapas. A primeira etapa ocorreu no primeiro semestre de 2006, durante o acompanhamento e desenvolvimento de todas as atividades das disciplinas de Prática de Ensino de Física IV e V, com carga horária de quatro créditos semanais, durante 15 semanas, totalizando 60 horas-aula no semestre. Desse total, 70\% das aulas (42 horas-aula) foram presenciais, orientados pelo docente da disciplina, nas quais os licenciandos discutiram temas relacionados ao ensino de Física. Os demais 30\% das aulas (18 horas-aula) foram reservados para o estágio de observação de aulas de Física junto a classes regulares do Ensino Médio. Tais observações permitiram que os futuros professores verificassem elementos da realidade das salas de aula, observando nas situações de ensino e aprendizagem o desempenho dos professores em exercício. Após as observações, os futuros professores apresentaram, por meio de relatórios e de discussões realizadas nas aulas presenciais, a avaliação de suas atividades de estágio. Paralelamente às discussões e observações sobre o estágio, os licenciandos planejaram e elaboraram materiais e atividades de ensino de 
Física que constituíram no curso ministrado aos alunos do Ensino Médio, no segundo semestre, sob a forma de Estágio de Regência.

O curso ministrado aos alunos do Ensino Médio foi planejado pelos licenciandos adotando os seguintes procedimentos: os licenciandos foram divididos em sete grupos, e cada grupo planejou e elaborou um plano de curso (referente a um módulo de ensino de oito horas) sobre um tema de Física escolhido por cada grupo: mecânica, termologia, óptica, eletricidade, eletromagnetismo, astronomia e física moderna e contemporânea.

No segundo semestre do mesmo ano, segunda etapa de constituição dos dados, os módulos de ensino planejados no primeiro semestre foram aplicados no Ensino Médio de uma escola pública como parte das disciplinas de Práticas de Ensino de Física VI e VII, as quais abrangiam o Estágio de Regência.

As disciplinas foram oferecidas durante 15 semanas, totalizando 75 horas-aula no semestre; $60 \%$ dessa carga horária equivalente a 45 horasaula, foram presenciais, e $40 \%$, equivalente a 30 horas-aula foram reservadas para o estágio de regência. No estágio, cada um dos grupos ministrou aulas referentes a um dos módulos de ensino. Essas aulas foram gravadas em videocassete.

O curso, planejado e ministrado pelos licenciandos foi intitulado "O outro lado da Física" e teve uma carga horária total de 56 horas-aula. As aulas foram desenvolvidas semanalmente, às segundas e terças-feiras, no período noturno, das 19h às 23h. Cada grupo de licenciandos, portanto, dispôs de dois conjuntos de quatro horas-aula, ou seja, oito horas-aula para ministrar cada um dos tópicos escolhidos. Os alunos de Ensino Médio, 1a e e 2ª séries, matriculados no curso foram escolhidos entre alunos do período matutino, para que as aulas não interferissem em suas atividades regulares.

As aulas ministradas no curso foram também cuidadosamente transcritas. Realizamos, a partir dessas transcrições, um mapeamento (identificação) de episódios de ensino de interesse para as questões de estudo.

\section{Análise e interpretação dos dados}

Estão sendo analisados todos os discursos provenientes das 56 horas/ aula de curso ministrados nos sete tópicos mencionados anteriormente, os 
quais revelam todo o contexto interativo discursivo entre futuros professores (licenciandos) e alunos. Ao mesmo tempo, decidimos por organizar a análise em duas fases:

1 - Análise do contexto interativo discursivo em sala de aula, verificando posturas discursivas assumidas tanto pelos licenciandos quanto pelos alunos, verificando a influência daquelas nos processos de ensino e de aprendizagem.

2 - Análise das condições de produção da analogia relacionadas à: Influência do domínio conceitual do licenciando (conhecimento do conteúdo) no processo explicativo envolvendo o uso de analogias; utilização de analogias como recurso de transformação do conteúdo: (a) isoladamente ou em conjunto com outros recursos. Quais? Em conexão com que conteúdos?; (b) em diferentes etapas da dinâmica da construção de explicações (ex.: criação de diferenças, construção de entidades etc.); ocorrência ou não das analogias durante o período de observação nos módulos de ensino, verificando o nível de organização de tais analogias; frequência com que aparecem nos sete módulos, levando-se em conta se elas possuem alguma relação com a experiência profissional ou não do licenciando; intensidade de manifestação das analogias em sala de aula nos diferentes módulos; analogias como confirmação de compreensão do conteúdo por parte dos alunos; forma como estão sendo trabalhadas pelos licenciandos, etc.

Para entender o contexto em que ocorre a utilização da analogia em sala de aula, com base na dimensão comunicativa que se estabelece nas interações entre professores/licenciandos e alunos, enfatizando o caráter social da construção de significados nas interações discursivas, estamos utilizando o trabalho de Compiani (1996), o qual fornece categorias para analisar a construção do conhecimento científico em sala de aula baseada na compreensão do papel do discurso dos alunos e do professor. Definimos abaixo essas categorias.

A solicitação de informações é uma categoria que pode ser caracterizada pela necessidade que apresentam os atores do processo interativo em obter explicações ou esclarecimentos, interferindo decisivamente nos rumos do diálogo.

O fornecimento de pistas define-se pela ação indutiva do professor sobre a linha de raciocínio dos alunos e pela sua atitude em oferecer elementos que 
sustentem o aluno em uma trajetória de raciocínio previamente traçada, visando conduzi-lo à resolução de um problema.

O reespelhamento é uma postura adotada pelo professor para encorajar a fala do aluno. Investido da autoridade discursiva, o professor, ao repetir com ênfase ou ao gesticular favoravelmente atribui legitimidade à ideia do aluno.

A problematização indica uma atitude intencional, comumente do professor, mas que pode partir também do aluno, de investigar, estudar, provocar reflexões em busca de respostas para determinado problema.

A reestruturação é a atitude de reorganização das proposições feitas durante as interações discursivas, constituindo-se como sistematização final ou parcial de ideias que foram discutidas sobre um determinado assunto.

A recondução caracteriza-se pela retomada, por parte do professor, da pertinência das discussões que se estabelecem em sala de aula.

Desse modo, estamos analisando os discursos provenientes das interações professor/alunos, considerando as categorias descritas acima nas suas diferentes formas interativas. Dos discursos provenientes das transcrições do curso $O$ outro lado da Física, selecionamos um episódio de ensino referente ao tópico de Termologia, especificamente no qual há recorrência a analogias durante o processo de interação discursiva entre professor/aluno. Para facilitar a análise dos dados, decidimos organizar os discursos em turnos de fala ${ }^{3}$, os quais descrevem a relação discursiva estabelecida entre professores e alunos.

\section{Episódio}

(01) Licenciando L4 Que é o seguinte... lá atrás, na aula de ontem, ficou claro, evidente, todo mundo concordou, que o calor, ele iria fluir de um corpo que estava a uma temperatura maior, para o corpo que estava a uma temperatura menor.

3 Os turnos não estão seguindo a sequência numérica da transcrição como um todo, ou seja, decidimos, para facilitar a análise neste trabalho, iniciar a partir do número 01. 
(02) Licenciando L3 É. Foi um dos modelos do [...] Esqueci o nome dele [... (aponta para o aluno A1)

(03) Aluno A1 Bruno.

(04) Licenciando L3 Como?

(05) Aluno A1 Bruno.

(06) Licenciando L3 Bruno. É o modelo do Bruno.

(07) Licenciando L1 Exatamente. A gente chegou a esta conclusão com base no modelo do Bruno.

(08) Licenciando L3 Mas só por nome, isso daí no livro eles chamam a Primeira Lei da Termodinâmica.

(09) Licenciando L4 Exatamente. Passou por um troço chamado a Primeira Lei da Termodinâmica. Essa primeira lei diz assim: que se você tem dois objetozinhos quaisquer (desenha dois quadrados na lousa), eu vou fazer uma coisa que o professor de física costuma fazer aqui, que eu acho muito chato, mas eu vou fazer mesmo assim [...] Vou batizar estes corpos: A e B.

O licenciando inicia trabalhando com informações já dadas, envolvendo os alunos no processo de reestruturação, recapitulando (01) a aula anterior. De acordo com Edwards e Mercer (1988), o professor muitas vezes utiliza a aula anterior como sendo uma introdução para o novo conhecimento, ou seja, como continuidade do que havia feito anteriormente. Nesse processo, a recapitulação possui um importante papel, pois elas possuem a função de assegurar que a compreensão dos aspectos importantes do que foi dito e feito sobre o que foi desenvolvido tenha sido feita de forma conjunta. Mas ressaltam também que a recapitulação, quando é explícita pelo professor, pode convergir em dois sentidos: para trás, ao fechar uma conceitualização de experiência e atividade conjunta significante em uma linguagem comum (01), e para frente, ao criar um contexto mental ${ }^{4}$ compartilhado, que serve como marco conceitual conjunto para compreender a nova criatividade e ensinar o que vem depois (08 e 09).

4 A concepção de contexto é entendida como algo mental, ou seja, "como uma propriedade das compreensões gerais que surgem entre as pessoas que se comunicam; não como uma propriedade do sistema linguístico que utilizam, ou das coisas que se têm feito e dito realmente, nem tão pouco das circunstâncias físicas em que as pessoas se encontram [...] tudo o que os participantes em uma conversação conhecem e compreendem [...] o que lhes ajuda a dar sentido ao que se diz" (Edwards, Mercer, 1988, p.78). 
Ao mesmo tempo, os licenciandos L1 (07) e L4 (09) utilizam-se do espelhamento reespelhamento (Compiani, 1996) (09) para reforçar as informações introduzidas, repetindo-as, reforçando a importância delas. Além disso, o reespelhamento de L4 vem acompanhado de uma "réplica elaborada”, com acréscimo de informações pertinentes àquelas introduzidas pelo falante precedente, no caso L3.

Podemos notar também que a posição do professor consiste em fazer uma pergunta e fornecer simultaneamente pistas (02) para a resposta. Com isso, o professor e os alunos "se vêm com frequência fechados em uma estrutura rotineira de diálogo de perguntas e respostas (estrutura IRA), na qual o professor obtém a resposta, avalia, assinala turnos de fala etc" (Edwards, Mercer, 1988, p.125). Além disso, o licenciando L1 faz menção à primeira lei da termodinâmica ${ }^{5}$ sem fazer qualquer referência ao conceito de trabalho, o que torna a explicação do conceito incompleta. Em seguida, ao começar explicar o que é calor, o faz de maneira convencional como descrito nos manuais escolares e feito pela maioria dos professores, e mesmo não aceitando que seja a melhor das explicações diz: "eu acho muito chato; mas eu vou fazer mesmo assim".

Outra questão que merece destaque é a postura do professor com relação ao uso das palavras, pois se o papel do professor é criar um vocabulário comum que, segundo Edwards e Mercer (1988), é de extrema relevância também, ele precisa tomar cuidado com uso das palavras ao destacar aspectos significativos da explicação, como, por exemplo, o uso de termos como "troço"; "objetozinhos" depois "corpos" (09). Ou seja, proporcionar um vocabulário conceitual compartilhado é, evidentemente, um dos objetivos implícitos, importante, do professor, pois os alunos têm que fixar os termos de referência usados na ciência e não aqueles do professor. Em seguida, detém-se sobre o conceito de fluxo de calor.

(10) Licenciando L4 Aí, a gente vai fingir que o A está mais aquecido que o $\mathrm{B}$; quer dizer: $\mathrm{o} A$ tá quente, e $\mathrm{o} \mathrm{B}$ tá frio; ou o $\mathrm{A}$ tá mais quente, o B tá mais frio (escreve na lousa $\mathrm{T}_{\mathrm{A}}>\mathrm{T}_{\mathrm{B}}$ ). Se eu puser os dois em contato, pode ser assim, ó[...] não precisa ser encostado, tá? Em contato, eu digo assim[...] o Sol está em contato com a Terra?

5 A variação da energia interna de um sistema é dada pela diferença entre o calor trocado com o meio exterior e o trabalho realizado no processo termodinâmico, ou seja, $\mathrm{DE}_{\text {int }}=\mathrm{Q}-\mathrm{W}$. 
(11) Alunos

(12) Licenciando L4

(13) Aluno 5

(14) Licenciando L4

(15) Aluno 1

(16) Outros alunos

(17) Licenciando L4

(18) Aluno 1

(19) Licenciando L4

(20) Vários alunos

(21) Licenciando L4

(22) Licenciando L1

Não.

Mas em contato térmico?

Sim.

Por que não chega lá[...] o calor emitido pelo Sol não chega aqui? Então[...] contato térmico não precisa você estar encostado... se este daqui está mais quente, do jeito que eu escrevi aqui (na lousa), um mais aquecido que o outro, a temperatura de um é maior que a do outro, vai haver um fluxo de calor?

Depende, se os dois estiverem em contato [...] Vai, sim.

Estando em contato térmico! Ah, sim!

Supondo [que] sim, existe a possibilidade deles trocarem energia, existe a possibilidade de fluxo de calor, nada impede, não tem nada impedindo, mesmo o vácuo possibilita o fluxo de calor. Ou a existência do fluxo de energia que é o calor, certo? Agora, se este fluxo existir, qual vai ser o sentido dele?

De A para B!

De A para B.

De A para B? (desenha uma seta na lousa do quadrado A para o B) Por que o fluxo de energia, por que o calor [...] flui neste sentido aqui? Agora me diz [...] aqui que está a filosofia que eu falei... Por quê?

Continuando, o licenciando L4 suscita a imaginação dos alunos para que eles evoquem mentalmente (10). Isto é, o licenciando quis dizer que a temperatura de $\mathrm{A}$ é maior que a temperatura de $\mathrm{B}$. O termo temperatura deveria ter sido utilizado já que o "calor" é frequentemente confundido com "temperatura". Novamente volta a questão ressaltada anteriormente com relação ao uso de terminologias cientificamente aceitas para trabalhar a explicação. Posteriormente, prosseguindo em sua explicação, ao inserir o conceito de "contato térmico", o licenciando não deixa claro de qual "contato" está falando, pois se levarmos em consideração a definição do termo "contato" ${ }^{6}$, veremos que os elementos em questão se tocam, mas de acordo

6 Contato: estado ou situação dos corpos que se tocam; comunicação; conexão. (Ferreira, 2001, p.180) 
com o licenciando, isso não precisa ocorrer. Para explicar de qual "contato" ele está falando, pergunta aos alunos: "o Sol está em contato com a Terra?". Um dos alunos responde que Sol e Terra não estão em "contato".

Ao notar a falha na forma como havia feito a pergunta, ele fornece outra informação (12), remodelando a pergunta inicial. Além disso, podemos notar também que, ao refazer a pergunta, o licenciando atesta automaticamente que a resposta do aluno não é satisfatória ou não está correta. Fato este apontado por Coll e Solé (1996) ao destacar que a "repetição de uma pergunta do professor, após uma resposta do aluno, deve levar a interpretar que tal resposta era incorreta” (p.295). Além disso, notamos que, lançando mão da analogia "sistema Sol-Terra" (análogo), tendo como situação alvo o entendimento do sistema de elementos A-B, o licenciando tenta fazer com que os alunos percebam a diferença da palavra "contato" para a palavra "contato térmico". Mas notamos que o licenciando praticamente não explora a analogia proposta, ou seja, apenas ressalta que "contato térmico não precisa você estar encostado" e retoma o sistema de elementos A-B.

No transcorrer da explicação, o licenciando L4 reconduz (14) a discussão da ideia principal inicialmente tratada nas discussões, a troca de energia entre os elementos A-B, explorando, dessa forma, o conceito de calor. No entanto, em seguida, ao questionar os alunos sobre o conceito de fluxo de calor, esperando uma resposta satisfatória, é surpreendido pela resposta do aluno A1 que responde reforçando a ideia de que dependeria do tipo de "contato". Essa réplica do aluno não era exatamente o que o licenciando esperava ouvir, pois julgava ter proporcionado todos os esclarecimentos necessários para o entendimento do conceito ao ter utilizado a analogia do sistema Sol-Terra. Com essa atitude, o aluno A1 volta a problematizar (15) o conceito de "contato", cuja resposta vem na sequência de uma contraposição geral dos outros alunos, a qual acaba servindo para o desenvolvimento da aula e para fazer com que o licenciando tome mais cuidado ao empregar os termos corretos nas perguntas, pois a forma como ela é elaborada implica na resposta recebida.

Nesse caso, podemos ressaltar outra característica identificada pelos estudos de Edwards e Mercer (1988), que é o fato de que, ao fazer uma pergunta, o professor espera que a resposta deva estar relacionada ao que foi tratado em sala de aula. Isso se levarmos em conta o fato de que ninguém faz perguntas a alguém sem supor de maneira razoável que essa pessoa possa 
conhecer a resposta. Para o professor, segundo os autores, esse curso permite alcançar o conhecimento compartilhado, pois os alunos respondem baseando suas respostas no que lhes foi ensinado na sala de aula. E já que lhes foi ensinado o que significa estar em "contato" e em "contato térmico", é plausível a pergunta feita pelo aluno A1. Em seguida, o licenciando novamente reconduz a explicação (19) em torno da ideia principal e, ao perguntar sobre o conceito em questão, fluxo de calor, obtém as respostas aguardadas, as quais são, posteriormente, reespelhadas $(20,21)$ por dois licenciandos, legitimando-as.

Apesar de o licenciando fazer algumas possíveis inferências com base na analogia "sistema Sol-Terra", é com base no que conhece acerca do Sistema Solar e na constatação de que a Terra é aquecida pelo Sol que os alunos se convencem de que (a) não há necessidade de contato direto entre os corpos e aceitam que (b) o vácuo não representa um impedimento para o fluxo de calor.

\section{Algumas considerações}

Em um processo de interação discursiva de sala de aula, os futuros professores recorrem ao uso de analogias em suas explicações com o intuito de tornar a explicação mais clara, mais próxima de situações reconhecidas pelos alunos. As analogias, neste caso, são elaboradas em um contexto discursivo interativo, com predominância de discursos do tipo IRA (indagação, resposta, avaliação), nos quais prevalece o domínio das perguntas do professor sobre o discurso da sala de aula. Com isso, o professor e os alunos se vêm com frequência fechados em uma estrutura rotineira de diálogo de perguntas e respostas, na qual o professor obtém a resposta, avalia, assinala turnos de fala etc. Além disso, verificamos, também, que a maioria das respostas às perguntas dos futuros professores reportam-se a respostas simples, como "sim" ou "não", e as intervenções de espelhamento servem não apenas como formas de legitimação para a informação introduzida pelo falante precedente, mas também para reforçar a informação, a qual é de importância para todos.

No entanto, não há exploração adequada das analogias, uma vez que não são trabalhadas suas características mais relevantes, tanto em nível de 
similaridades quanto de limitações, fato já destacado por Duit (1991) ao dizer que o uso de analogias em situações de aprendizagem exige orientações consideráveis. Por fim, os resultados deste estudo estão mostrando que se fazem urgentes maiores discussões sobre o uso de analogias no ensino, na formação inicial dos professores, sua função, suas utilidades, suas vantagens e desvantagens, como usar analogias de uma forma efetiva e, além disso, como o contexto interativo discursivo entre professor/aluno pode interferir nesse processo em sala de aula.

Dessa forma, se pretendemos proporcionar que nossos alunos se apropriem de uma linguagem cientificamente aceita, devemos, sobretudo, proporcionar um ambiente encorajador que possibilite que essa apropriação seja efetivada. Para isso, devemos levar em conta o perfil didático do professor, como o discurso é empregado, contribuindo ou não para um conhecimento científico.

\section{Referências bibliográficas}

CINDRA, J. L.; TEIXEIRA, O. P. B. A evolução das ideias relacionadas aos fenômenos térmicos e elétricos: algumas similaridades. Caderno Brasileiro de Ensino de Física, v.22, n.3, pp.379-399, 2005.

COLL, C.; EDWARDS, D. (Orgs.) Ensino, aprendizagem e discurso em sala de aula. Porto Alegre: Artes Médicas, 1998.

.; SOLÉ, I. A interação professor/aluno no processo de ensino e aprendizagem. In: COLL, C.; PALACIOS, J.; MARCHESI, A. (Orgs.). Desenvolvimento Psicológico e Educação. Porto Alegre: Artmed, v.2, pp.281-298, 1996.

COMPIANI, M. As geociências no ensino fundamental: um estudo de caso sobre o tema: "A formação do Universo". Campinas. Tese (Doutorado em Educação)Faculdade de Educação, Universidade Estadual de Campinas, 1996.

DAGHER, Z. Analysis of analogies used by science teachers. Journal of Research in Science Teaching, v.32, n.3, pp.259-270, 1995.

DELAMONT, S. Interação na sala de aula. Livros Horizonte: Methuen. 1987.172p.

DUARTE, M. da C. Analogias na Educação em Ciências: Contributos e Desafios. Investigações em Ensino de Ciências, v.10, n.1, pp.7-29, 2005.

DUIT, R. On the role of analogies and metaphors in learning science. Science Education, v.75, pp.649-72, 1991.

EDWARDS, D.; MERCER, N. El conocimiento compartido: el desarrollo de la comprensión en el aula. Barcelona: Centro de Publicaciones del MEC y Ediciones Paidós Ibérica, S. A., 1988. 
FERREIRA, A. B. H. Miniaurélio século XXI escolar: o minidicionário da língua portuguesa. 4.ed. Rio de Janeiro: Nova Fronteira, 2001.

GALAGOVSKY, L.; ADÚRIZ-BRAVO, A. Modelos y analogías en la enseñanza de las ciencias naturales. El concepto de modelo didáctico analógico. Enseñanza de Las Ciencias. v.19, n.2, pp.231-242, 2001.

; BONÁN, L.; ADÚRIZ BRAVO, A. Problemas con el lenguaje científico en la escuela. Un análisis desde la observación de clases de ciencias naturales. Enseñanza de las Ciencias, v.16, n.2, pp.315-321, 1998.

GODOY, L. A. Éxitos y Problemas de las analogías en la enseñanza de la Mecánica. Journal of Science Education, v.3, n.1, pp.11-14, 2002.

MARTINS, I.; OGBORN, J.; KRESS, G. Explicando uma explicação. Ensaio, v.1, n.1, 1999.

MERCER, N. As perspectivas socioculturais e o estudo do discurso em sala de aula. In: COLL, C.; EDWARDS, D. (Orgs.) Ensino, aprendizagem e discurso em sala de aula. Porto Alegre: Artes Médicas, pp.13-28, 1998.

; TEIXEIRA, O. P. B. Uma análise das interações dialógicas em aulas de ciências nas séries iniciais do ensino fundamental. Investigações em Ensino de Ciências, v.9, n.3, 2004.

MORTIMER, E.; SCOTT, P. Atividade discursiva nas salas de aula de ciências: uma ferramenta sociocultural para analisar e planejar o ensino. Investigações em Ensino de Ciências, v.7, n.3, pp.283-306, 2002.

MORTIMER, E. F.; MACHADO, A. H. Elaboração de conflitos e anomalias em sala de aula. In: __ _ SMOLKA, A. L. (Orgs.) Linguagem, cultura e cognição: reflexões para o ensino e a sala de aula. Belo Horizonte: Autêntica, pp.139-150, 2001.

OLIVA, J. M. Qué conocimientos profesionales deberíamos tener los profesores de ciencias sobre el uso de analogías. Rev. Eureka Enseñ. Divul. Cien., v. 5, n.1, pp.15-28, 2008.

OGBORN, J. et al. Explaining Science in the Classroom. Milton Keynes: Open University Press, 1996.

ORGILL, M.; BODNER, G. What research tells us about using analogies to teach chemistry. Chemistry Education, v.5, pp.15-32, 2004.

PONTECORVO, C.; AJELLO, A. M.; ZUCCHERMAGLIO, C. Discutindo se aprende: interação social, conhecimento e escola. Porto Alegre: Artmed, 2005. 
SOBRE O LIVRO

Formato: $16 \times 23 \mathrm{~cm}$

Mancha: 27,5 $\times 49,0$ paicas

Tipologia: Horley Old Style 11/15

1a edição: 2009

EQUIPE DE REALIZAÇÃO

Coordenação Geral

Marcos Keith Takahashi 


\section{CULTURA}

ACADÊMICA

$\overrightarrow{\text { Editona }}$ 